\title{
BRUNO STUPELLO
}

Perspectiva de desenvolvimento da infraestrutura de transportes para escoamento da produção agrícola da região Centro-Oeste do Brasil: um exercício de planejamento estratégico de transportes 


\section{BRUNO STUPELLO}

Perspectiva de desenvolvimento da infraestrutura de transportes para escoamento da produção agrícola da região Centro-Oeste do Brasil: um exercício de planejamento estratégico de transportes

Dissertação apresentada à Escola Politécnica da Universidade de São Paulo para obtenção do título de Mestre em Engenharia

Área de concentração:

Engenharia Naval e Oceânica

Orientador: Professor Doutor Marcos Mendes de Oliveira Pinto

São Paulo 
FICHA CATALOGRÁFICA

\section{Stupello, Bruno}

Perspectiva de desenvolvimento da infraestrutura de trans portes para escoamento da produção agrícola da região CentroOeste do Brasil: um exercício de planejamento estratégico de transportes / B. Stupello. -- São Paulo, 2011.

p. 158

Dissertação (Mestrado) - Escola Politécnica da Universidade de São Paulo. Departamento de Engenharia Naval e Oceânica.

1. Planejamento de transportes 2. Infraestutura de transportes I. Universidade de São Paulo. Escola Politécnica. Departamento de Engenharia Naval e Oceânica II. t. 


\section{AGRADECIMENTOS}

Agradeço a todos que colaboraram para a realização desta dissertação de mestrado:

Ao meu orientador e amigo, Prof. Dr. Marcos Pinto, que me mostrou os caminhos a serem seguidos com muita paciência, na dissertação e também na vida.

Aos meus pais, minha irmã e irmão, pela educação, pela dedicação, pelo incentivo, companheirismo e paciência pelas ausências.

A minha namorada Helga, pelo incentivo, companheirismo, ajuda nas revisões e paciência nas ausências.

A todos meus amigos do CEGN, principalmente Alfonso, David, Guilherme, João, Julio, Tiago, Tiffany e Valdir, pela oportunidade e confiança no meu trabalho.

Ao restante dos meus familiares e amigos, em especial Daniel e Rodrigo, que, de alguma forma, direta e indiretamente, contribuíram na elaboração do presente estudo. 


\section{Resumo}

Este trabalho realiza um exercício de planejamento estratégico de transportes com foco na infraestrutura de escoamento da produção agrícola da região Centro-Oeste do Brasil.

O trabalho parte da compreensão dos fundamentos do planejamento estratégico da infraestrutura de transportes, avalia o pretenso planejamento brasileiro e compreende porque ele não é de fato um planejamento estratégico.

A compreensão da multidisciplinaridade dos objetivos do planejamento orienta um tratamento multicritério. A partir da definição de objetivos o autor aplica o método Analytic Hierarchy Process (AHP) e elenca, através de indicadores, uma ordem de prioridades na execução de um conjunto de obras na região. A partir do exercício simplificado orienta um trabalho de maior envergadura - em termos de escopo e metodologia - que deveria ser feito para um efetivo planejamento estratégico de infraestrutura de transportes para Brasil.

Palavras chave: Planejamento estratégico, Infraestrutura de transportes 


\begin{abstract}
This study develops an exercise of strategic planning of a transport system for the handling of agricultural products of Brazil's Midwest.

The work begins by exploring the concepts underlying the strategic planning of a transport infrastructure. Thereafter, it assesses the document presented by the Brazilian government as the national transport system strategic planning, and argues that this document does not fulfill the characteristics of a typical strategic planning.

The consideration of the diverse objectives of the strategic planning requires a multicriteria approach. The author lists several general objectives to guide the transport system strategic planning and employs the Analytic Hierarchy Process (AHP) to define the priority ones. The most relevant objective is then used to rank the main infrastructure works in the region.

The exercise developed in this study suggests that to develop an effective strategic planning of the Brazil's transport system, a broader and deeper work in terms of scope and methodology must be undertaken.
\end{abstract}

Keywords: Strategic planning, transport infrastructure 


\section{Lista de figura}

FIGURA 1: LOOPING DE FEEDBACK DE PLANEJAMENTO ESTRATÉGICO E TERMINOLOGIA PADRÃO DA TEORIA DE CONTROLE (EM COLCHETES). FONTE: KÖLBL, NIEGL E KNOFLACHER (2008).

FiguRa 2: PROCESSO "IDEAL" DE TOMAdA DE DECISÃo NA ABORDAGEM GUIADA POR PLANEJAMENTO. FonTE: EMBERGER, ET AL, (2009)

FigURA 3: FRAMEWORK DO PLANEJAMENTO DE TRANSPORTES NA AUSTRÁLIA DISCUTIDO EM ATC (2006) ....32

FIGURA 4: ELEMENTOS DO SISTEMA DE TRANSPORTES. FonTE: ATC (2006)..... .35

Figura 5: Esquema de deCISÃo HIERÁRQUICO GENÉRICO. AdAPTAdo de Colin (2007). . .42

Figura 6: Plano RodoviÁRIo NACIONAL de 1944. Fonte: GEIPOT (2001)... 49

FIGURA 7: AVANÇO DAS ÁREAS PLANTADAS NO CO DE 1990 A 2005. FonTE: AdAPTADO DE CEGN (2010).72

Figura 8: Corredores de exportação do Centro-Oeste e suas possíveis rotas. Fonte: ELABORAÇÃO AUTOR

FIGURA 9: CONDIÇÃO DAS RODOVIAS UTILIZADAS PARA O ESCOAMENTO DA PRODUÇÃO DO CENTRO-OESTE. FONTE: ELABORAÇÃO AUTOR. .78

Figura 10: MAPEAMENTO E CONDIÇÕES do CORREDOR DE EXPORTAÇÃO SORRISO - SANTOS. Fonte: ELABORAÇÃO AUTOR . .79

FIGURA 11: MAPEAMENTO E CONDIÇÕES do CORREDOR DE EXPORTAÇÃO SORRISO - PARANAGUÁ. FONTE: ELABORAÇÃO AUTOR . .80

Figura 12: MAPEAMENTO E CONDIÇÕES do CORREDOR DE EXPORTAÇÃo SORRISO - SANTARÉM. FontE: ELABORAÇÃO AUTOR

Figura 13: MAPEAMENTO E CONDIÇÕES do CORREDOR DE EXPORTAÇÃO CAMPO NOVO DO PARECIS ITACOATIARA. FONTE: ELABORAÇÃO AUTOR.

Figura 14: MAPEAMENTO E CONDIÇÕES DO CORREDOR DE EXPORTAÇÃO MARACAJU - SANTOS. FONTE: ELABORAÇÃO AUTOR

FIGURA 15: MAPEAMENTO E CONDIÇÕES DO CORREDOR DE EXPORTAÇÃO SUL DE GOIÁS-SANTOS. FONTE: ELABORAÇÃO AUTOR

FIGURA 16: MAPEAMENTO E CONDIÇÕES DO CORREDOR DE EXPORTAÇÃO SUL DE GOIÁS-VITÓRIA. FONTE: ELABORAÇÃO AUTOR

FIGURA 17: MAPEAMENTO dOS INVESTIMENTOS DO PNLT COM FOCO NO CO. FONTE: CEGN (2010) .90

FiguRA 18: MAPEAMENTO dOS INVESTIMENTOS PREVISTOS NO PAC 1 COM FOCO NO CO. FONTE: CEGN (2010)

FIGURA 19: FASES DO PLANEJAMENTO DO SISTEMA DE TRANSPORTE. FONTE: AdAPTADO DE ATC (2006) ....94 
FIGURA 20: METOdOLOGIA DO EXERCíCIO SIMPLIFICADO APRESENTADO. FONTE: ELABORAÇÃO AUTOR .95

FIGURA 21: HIERARQUIA PARA PRIORIZAÇÃO DOS OBJETIVOS. FONTE: FONTE: ELABORAÇÃO AUTOR 101

FIGURA 22: ÁREA DE INFLUÊNCIA DETERMINADA POR BISSETRIZES TRAÇADAS A CADA PAR DE PORTOS. FONTE: ELABORAÇÃO AUTOR 114

FIGURA 23: COMPARAÇÃO DA ÁREA DE INFLUÊNCIA DOS PORTOS POR BISSETRIZES E ISOCUSTO DE TRANSPORTE NO CENÁRIO ATUAL DE INFRAESTRUTURA. FONTE: ELABORAÇÃO AUTOR 115

FIGURA 24: OBRAS LISTADAS NO PNLT E NO PAC 1 QUE AFETAM A INFRAESTRUTURA DE TRANSPORTES DO CO. FONTE: ADAPTADO DE CEGN (2010) 116

FIGURA 25: COMPARAÇÃO DA ÁREA DE INFLUÊNCIA DOS PORTOS POR EQUIDISTÂNCIA E ISOCUSTO DE TRANSPORTE COM OBRAS DO PAC E PNLT. FONTE: ELABORAÇÃO AUTOR. 118

FIGURA 26: ÁREA DE INFLUÊNCIA dA HIDROVIA TAPAJÓs-TELES PIRES. FonTE: ELABORAÇÃO AUTOR 121

FIGURA 27: HIERARQUIA PARA PRIORIZAÇÃO DOS OBJETIVOS. FONTE: ELABORAÇÃO AUTOR. 131

FIGURA 28: ÓRGÃOS ATUANTES NO SETOR DE TRANSPORTE (AdAPTADO DE GOLDBERG, 2009) 140 


\section{Lista de Gráficos}

GRÁFICO 1: BALANÇO dE EVOLUÇÃO dAS OBRAS do PAC 1 - INCLUI HABITAÇÃO E SANEAMENTO. FONTE: PAC

Gráfico 2: ReCursos do PAC InVEStidos até AbRIL de 2010 EM logísticA de tRANSPORTES. Fonte: PAC.

GRÁFICO 3: META DA DISTRIBUIÇÃO DE CARGA ENTRE OS MODAIS PARA O ANO DE 2023, APÓS IMPLANTAÇÃO DAS OBRAS DO PNLT. FONTE: PNLT (2007)

Gráfico 4: VARiação anUal do PIB E do InVEStimento total EM R\$ DE 2008, eNTRE 1962 E 2008. FONTE: BANCO MUNDIAL / GOLDBERG (2009). .66

GRÁFICO 5: TAXA DE INVESTIMENTO EM INFRAESTRUTURA No BRASIL ENTRE 1980 E 2001 (\% PIB). FonTE: BANCO MUNDIAL / GOLDBERG (2009) .66

GRÁFICO 6: RECEITA GOVERNAMENTAL E INVESTIMENTOS EM QUATRO SETORES PÚBLICOS BÁSICOS. FONTE: PORTUGAL (2008) 68

GRÁFICO 7: EVOLUÇÃO dA ÁREA PLANTADA NACIONAL E POR REGIÃO. FONTE: IBGE / ELABORAÇÃO: AUTOR 71

GRÁFICO 8: CoMpaRAÇÃO ENTRE ESTAdOS DE DENSIDADE DE RODOVIAS (EXTENSÃO DE RODOVIAS/ ÁREA TOTAL). FONTE DE DADOS: IBGE E GEIPOT (2001) / ELABORAÇÃO: AUTOR .74

GRÁFICO 9: COMPARAÇÃO ENTRE ESTADOS DE DENSIDADE DE RODOVIAS (EXTENSÃO DE RODOVIAS/ ÁREA PLANTADA). FONTE DE DADOS: IBGE E GEIPOT (2001) / ELABORAÇÃO: AUTOR ................................75

GRÁFICO 10: CONDIÇÃO DA MALHA RODOVIÁRIA. FONTE: CNT (2006) /DESTAQUES: AUTOR ........................75

GRÁFICO 11: CURVA DE FRETE RODOVIÁRIO (R\$/T.KM). FONTE: ELABORAÇÃO AUTOR ……..................... 111

GRÁFICO 12: CURVA DE FRETE FERROVIÁRIO (R\$/T.KM). FONTE: ELABORAÇÃO AUTOR..... 112

GRÁFICO 13: EMISSÃO DE CO 2 POR MOdAL [KG/ 1.000TKU]. FONTE: MINISTÉRIO DOS TRANSPORTES/ ANTAQ E U.S. DEPARTMENT OF TRANSPORTATION 


\section{Lista de Tabelas}

Tabela 1: Matriz de planejamento estratégico. Fonte: KölBL, Niegl e KNoflacher (2008). .26

TABELA 2: Descrição E ARMADILHAS dAS ABORdAGENS PARA tOMADAS DE DECISÃO ESTRATÉGICAS, SEGUNDO O DMG. FONTE: MAY ET AL, (2005) .27

TABela 3: EtAPAS DE PROCESSOS DE PLANEJAMENTO DE TRANSPORTES REALIZADOS NA EUROPA ENTRE 2001 E 2003. FonTE: KÖLBL, NiegL E KNOFLACHER (2008)

TABELA 4: INPUTS, PROCESSOS, ANÁLISES E OUTPUTS DAS FASES DE PLANEJAMENTO PROPOSTAS POR ATC (2006)

TABELA 5: EXEMPLOS DE ALINHAMENTO DE OBJETIVOS NOS DIFERENTES NÍVEIS. FONTE: ATC (2006)..... .35

TABELA 6: OBJETIVOS, MEDIDAS/INSTRUMENTOS E INDICADORES PARA O PLANEJAMENTO DE TRANSPORTES para o Meio-Ambiente. AdAPtado de Kölbl, Niegl e KNOFLACher (2008) .37

TABELA 7: OBJETIVOS, MEDIDAS/INSTRUMENTOS E INDICADORES PARA O PLANEJAMENTO DE TRANSPORTES para a ECONOMia AdAPtado de Kölbl, Niegl E KNOflacher (2008)

TABELA 8: OBJETIVOS, MEDIDAS/INSTRUMENTOS E INDICADORES PARA O PLANEJAMENTO DE TRANSPORTES

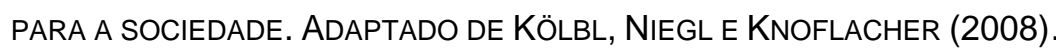
.39

Tabela 9: Escala de RazÃo. Fonte: SaAty (1991) .43

TABela 10: Comparação entre os PARES de CRItÉRIOS. Fonte: Colin (2007) 44

TABELA 11: ICAS EM FUNÇÃO DA ORDEM DA MATRIZ. FONTE: CoLIN (2007)..... 44

TABela 12: Planos desenvolvidos no BRASIL ENTRE 1940 e 2000. FonTE: ANDRADE, ET AL (2006) ......47

TABELA 13: TIRE E PERÍODO RECOMENDADO DE ENTRADA DAS OBRAS DO PNLT. FONTE: PNLT (2007) .....58

TABELA 14: DISTRIBUIÇÃO ENTRE OS MODAIS DOS RECURSOS DO PAC 2 TRANSPORTES. FONTE: PAC ........60

TABELA 15: ÁREA PLANTADA E PRODUÇÃO POR ESTAdO EM 2023. FonTE: CEGN (2010) ..........................73

TABELA 16: ÁREA PLANTADA POR ESTADO. FONTE DE DADOS: IBGE / ELABORAÇÃO: AUTOR .74

TABELA 17: DETALHAMENTO DAS ROTAS DO CORREDOR SORRISO - SANTOS. FONTE DE DADOS: CNT (2006) / ELABORAÇÃO: AUTOR .79

Tabela 18: Detalhamento das rotas do corredor Sorriso - ParanaguÁ. Fonte de dados: CNT (2006) / ELABORAÇÃO: AUTOR .81

TABela 19: Detalhamento das rotas do corredor Sorriso - SANTARÉm. Fonte de dados: CNT (2006) / ELABORAÇÃO: AUTOR .82

TABela 20: Detalhamento das Rotas do corredor CAmpo Novo do Parecis - ItAcoatiara. Fonte de DADOS: CNT (2006) / ELABORAÇÃO: AUTOR. 
TABela 21: Detalhamento das rotas do corredor Maracaju - SANTOS. Fonte de dados: CNT (2006) / ELABORAÇÃO: AUTOR

TABela 22: Detalhamento das rotas do corredor sul de Goiás-Santos. Fonte de dados: CNT (2006) / ELABORAÇÃO: AUTOR.

Tabela 23: Detalhamento das rotas do corredor sul de Golás-Vitória. Fonte de dados: CNT (2006) / ELABORAÇÃO: AUTOR

TABELA 24: CoMPARAÇÃo ENTRE PARES DE CRITÉRIOS. FONTE: ELABORAÇÃO AUTOR. 102

TABela 25: Prioridade Relativa da SEleÇÃo dos obJetivos. Fonte: ElaboraçÃo Autor 102

TABELA 26: ICAS EM FUNÇÃO DA ORDEM DA MATRIZ. FONTE: COLIN (2007) 104

TABELA 27: CoMpARAÇÃO ENTRE PARES E PRIORIDADES NÍVEL 3 - DeSENVOLVIMENTO ECONÔMICO. FonTE: ELABORAÇÃO AUTOR 104

TABela 28: ComparaçÃo entre PARES e PRIORIDAdes nível 3 - DesenVolvimento SOCIAL. Fonte: ELABORAÇÃO AUTOR 105

TABela 29: Comparação entre pares e prioridades nível 3 - Preservação ambiental. Fonte: ELABORAÇÃO AUTOR 105

TABELA 30: MATRIZ de PRIORIDADE DO NÍVEL 3 COM RELAÇÃo AO NÍVEL 2. FonTE: ELABORAÇÃO AUTOR .. 106

TABELA 31: PRIORIZAÇÃo DE OBJETIVOS. FontE: ELABORAÇÃO AUTOR 106

TABELA 32: EXEMPLO de CÁlCULO de FRETE AGREGADO PARA A MESORREGIÃo NORTE. FONTE: DAdOS: IBGE E CNT (2006) / ELABORAÇÃO AUTOR. 119

TABELA 33: ECONOMIA DE FRETE OBTIDA COM INVESTIMENTOS DO PAC E PNLT. FONTE: ELABORAÇÃO AUTOR 120

TABELA 34: CARGA CAPTADA PARA EXPORTAÇÃO PARA CADA CORREDOR E REDUÇÃO DE FRETE A CADA REAL INVESTIDO $(R)$ PARA OS PRINCIPAIS INVESTIMENTOS. FONTE: ELABORAÇÃO AUTOR 122

TABELA 35: CARGA CAPTADA PARA EXPORTAÇÃO PARA CADA CORREDOR E REDUÇÃO DE FRETE A CADA REAL INVESTIDO $(R)$ PARA TODOS OS INVESTIMENTOS NECESSÁRIOS PARA O CO. FONTE: ELABORAÇÃO AUTOR

TABELA 36: CARGA CAPTADA PARA EXPORTAÇÃO PARA CADA CORREDOR E REDUÇÃO DE FRETE A CADA REAL INVESTIDO (R) PARA TODOS OS INVESTIMENTOS NECESSÁRIOS PARA O CO. FONTE: ELABORAÇÃO AUTOR

Tabela 37: Priorização de obras atendendo o objetivo de menor emissão de $\mathrm{CO}_{2}$. Fonte: ELABORAÇÃO AUTOR 128

TABELA 38: AGÊNCIAS REGULADORAS NO BRASIL 145

TABELA 39: DetALHAMENTO dos InVESTIMENTOS Do PNLT. FonTE: CEGN (2010)...... 151 
TABELA 40: DetAlHAMENTo dos InVEStimentos do PAC. FonTE: CEGN (2010) 153

TABELA 41: TABELA DE FRETES [R\$/T] ATUAIS PARA TOdAS AS ROTAS. FonTE: ELABORAÇÃO AUTOR....... 155

TABELA 42: TABELA DE FRETES[R\$/T] FUtUROS PARA TODAS AS ROTAS. FontE: ELABORAÇÃO AUTOR ...... 157 


\section{LISTA DE ABREVIATURAS E SIGLAS}

ABCR - Associação Brasileira de Concessionários Rodoviários

AHP - Analytic Hierarchy Process

ANAC - Agência Nacional de Aviação Civil

ANATEL - Agência Nacional de Telecomunicações

ANCINE - Agência Nacional de Cinema

ANEC - Associação Nacional de Exportadores de Cereais

ANEEL - Agência Nacional de Energia Elétrica

ANP - Agência Nacional de Petróleo

ANS - Agência Nacional de Saúde Suplementar

ANTAQ - Agência Nacional de Transportes Aquaviários

ANTF - Agência Nacional de Transportes Ferroviários

ANTT - Agência Nacional de Transportes Terrestres

ANUT - Associação Nacional dos Usuários do Transporte de Cargas

ANVISA - Agência Nacional de Vigilância Sanitária

AP - Autoridades Portuárias

ASLOG - Associação Brasileira de Logística

BA - Bahia

BACEN - Banco Central do Brasil

CAGR- Compound Annual Growth Rate

CAP - Conselhos de Autoridade Portuária

CENTRAN - Centro de Excelência em Engenharia de Transportes

CF88 - Constituição Federal de 1988

CGPAC - Comitê Gestor do PAC

$\mathrm{CNI}$ - Confederação Nacional da Indústria

CNT - Confederação Nacional do Transporte

CO - Centro-Oeste

CONIT - Conselho Nacional de Infraestrutura de Transporte

DF - Distrito Federal

DNIT - Departamento Nacional de Infraestrutura de Transportes

EFVM - Estrada de Ferro Vitória Minas

FCA - Ferrovia Centro-Atlântica 
GEIPOT - Grupo Executivo de Integração da Política de Transportes GEPAC - Grupo Executivo do PAC GO - Goiás

IBAMA - Instituto Brasileiro do Meio Ambiente

MDIC - Ministério do Desenvolvimento, Indústria e Comércio Exterior

$M G$ - Minas Gerais

MMA - Ministério do Meio Ambiente

MnT - Ministério dos Transportes

MT - Mato Grosso

MS - Mato Grosso do Sul

OEMAs- Órgãos Estaduais de Meio Ambiente

OGU - Orçamento Geral da União

OMMAs - Órgãos Municipais de Meio Ambiente

PA - Pará

PAC - Programa de Aceleração do Crescimento

PIB - Produto Interno Bruto

PNLT - Plano Nacional de Logística e Transportes

PNV - Plano Nacional de Viação

RFFSA - Rede Ferroviária Federal S.A.

SEAE - Secretaria de Acompanhamento Econômico

SECEX - Secretaria de Comércio Exterior

SEP - Secretaria Especial dos Portos

SIFRECA - Sistema de Informação de Fretes

SP - São Paulo

SPNT - Secretaria de Política Nacional de Transportes

TCU - Tribunal de Contas da União

TIRE - Taxa Interna de Retorno Econômico

TKU - Tonelada quilômetro útil

TO - Tocantins

TU - Tonelada útil 


\section{Sumário}

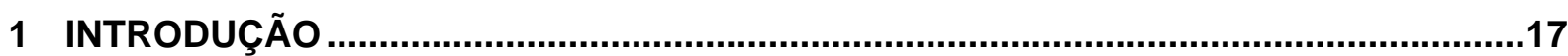

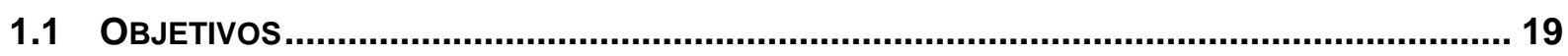

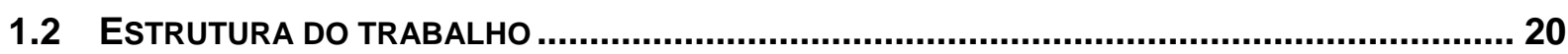

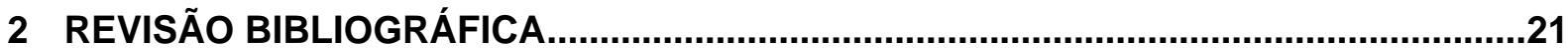

2.1 Planejamento estratéGico de transportes ................................................... 22

2.1.1 DECISÃO COM PROBLEMAS DE MÚLTIPLOS CRITÉRIOS ............................................. 40

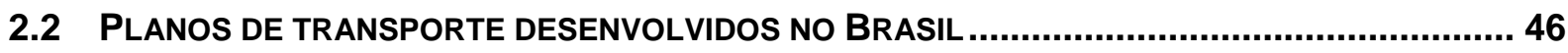

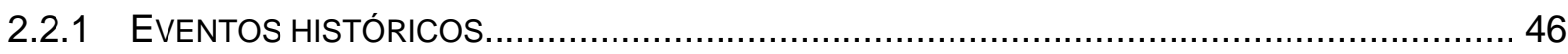

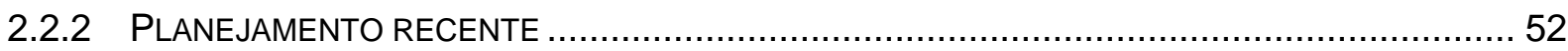

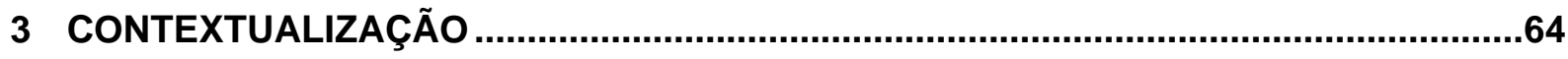

3.1 INVESTIMENTOS NO SETOR DE TRANSPORTES: DESENVOLVIMENTO RECENTE NO BRASIL . 65

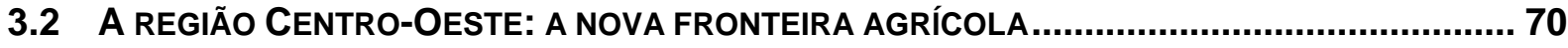

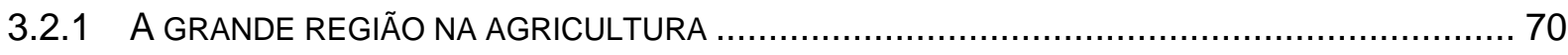

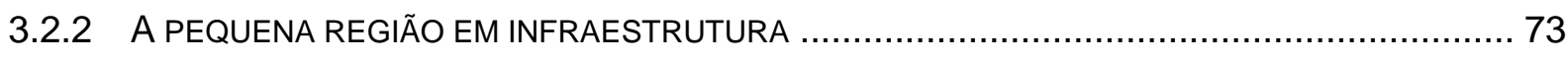

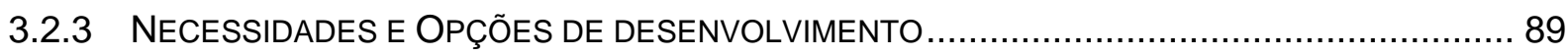

4 PLANEJAMENTO EStRAtÉgico DE TRANSPORTES: UM EXERCícIO

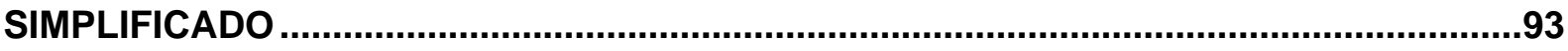

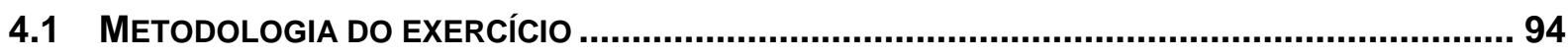

4.2 Objetivos do Planejamento Estratégico de transportes para a região

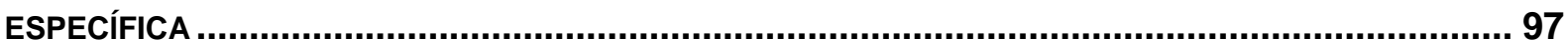

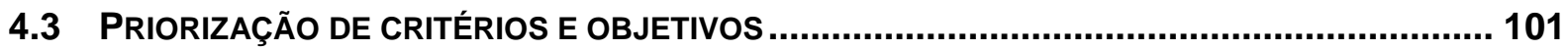

4.4 AVALIAÇÃo COMPARATIVA DAS OBRAS A LUZ DA PRIORIZAÇÃO DOS OBJETIVOS ADOTADOS 108 
4.4.1 GANHOS POTENCIAIS COM NOVOS CORREDORES: MAXIMIZAÇÃO DO RETORNO SOBRE O

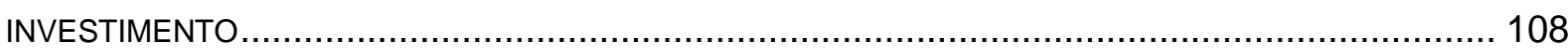

4.5 RESULTADOS: OBRAS PRIORITÁRIAS E DIFERENÇA COM A REALIDADE .......................... 126

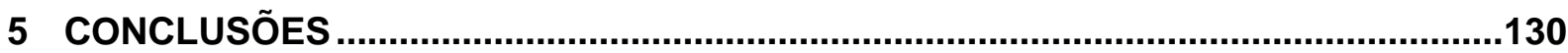

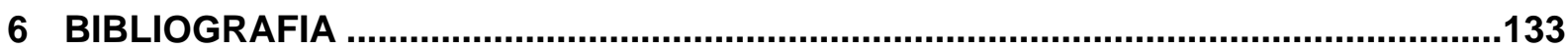

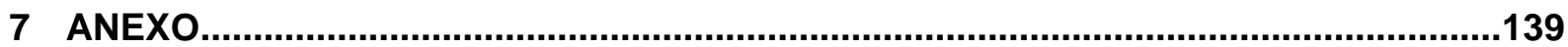

7.1 BREVE DESCRIÇÃO dOS AGENTES DO SETOR DE TRANSPORTES................................... 140

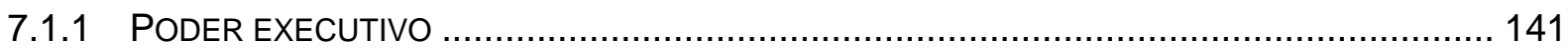

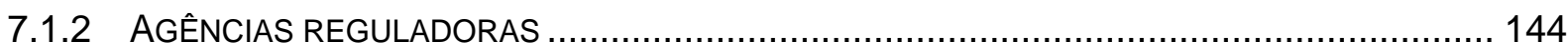

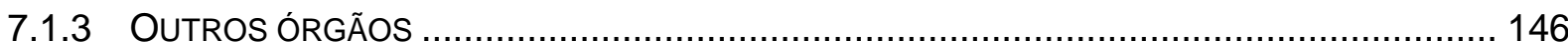

7.2 Detalhamento dos INVESTIMEnTOS Do PNLT e PAC .............................................. 151

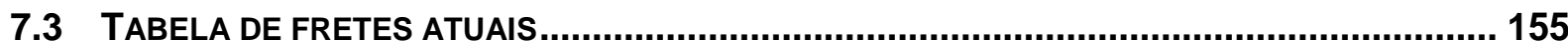

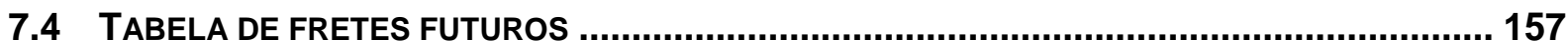




\section{Introdução}

O aumento paulatino do comércio mundial, associado ao fenômeno da globalização, foi intensificado nos últimos anos com o crescimento econômico acentuado dos países emergentes, em especial o da China. A crescente demanda por commodities minerais e agrícolas evidenciaram um Brasil carente em planejamento de transportes e consequentemente em infraestrutura logística.

O Brasil passou por um longo período sem investimento público em infraestrutura de transportes. Tal cenário, que foi motivado, entre outros, pelas alterações no cenário econômico mundial - resultado de crises, como as geradas pelos choques do petróleo -, só se reverteu a partir de 2002, com a entrada de capital privado no setor.

Em que pese essa recente retomada, o país está colhendo os frutos das décadas de 80 e 90, em que a infraestrutura de transportes pouco se desenvolveu. No cenário atual os produtos nacionais perdem competitividade e, em ciclos de baixa, a produção em áreas remotas perde sua viabilidade.

Uma das regiões brasileiras mais afetadas pelo chamado "apagão logístico" é a Centro-Oeste (CO), que, tendo iniciado sua ocupação tardiamente - efetivamente a partir da década de 80 - possui infraestrutura em estágio incipiente de desenvolvimento. A região possui potencial para triplicar a área plantada, exacerbando seu papel de fonte de alimentos num cenário de escassez mundial de áreas agriculturáveis. Todavia, para que isso seja possível, é preciso planejar estrategicamente os investimentos na sua malha multimodal de transportes.

As mudanças necessárias não se limitam a prover recursos para que os investimentos sejam feitos. O país carece de um planejamento estratégico na área, em que objetivos sejam estabelecidos e as diversas opções de investimento avaliadas com base nesses objetivos e no desenvolvimento das demandas.

A temática do planejamento estratégico de transportes deficiente no Brasil é o pano de fundo deste trabalho que busca, todavia, dar maior concretude na discussão das alternativas de desenvolvimento de sistemas de transporte para escoamento da produção do $\mathrm{CO}$. Essa maior concretude, quando comparada com os planos de governo (notadamente no Plano Nacional de Logística de Transportes - PNLT) se 
traduziria por objetivos claramente definidos e pela classificação de prioridade e pertinência das alternativas logísticas apresentadas pelo governo, buscando atender eficientemente aos objetivos estabelecidos.

A contribuição nesta seara exige a consolidação de um conjunto básico de conceitos e um entendimento da dinâmica do setor - que se pode denominar "massa crítica". No que tange ao estudo de infraestrutura de transportes para escoamento da produção agrícola de uma região, a criação desta "massa" passa por buscar respostas para diversas questões:

Quais as características da região em questão? Quais são e como se desenvolvem suas principais culturas? Qual a importância dessa região dentro do contexto agrícola nacional? Quais são as perspectivas de crescimento e qual o limite de produção da região? Quais são as principais rotas de escoamento dessa produção hoje e no futuro? O governo tem realizado esforços com o objetivo de planejar esse desenvolvimento? A velocidade de realização dos investimentos governamentais está em consonância com a necessidade de desenvolvimento econômico das regiões? Quais as melhores opções de investimentos em um cenário de recursos escassos? No caso brasileiro, quais são os objetivos a considerar? Os planos de investimentos do governo são os mais adequados e eficientes? O que é planejamento estratégico de transportes? Quais são os principais objetivos a serem alcançados?

Essas respostas irão guiar o desenvolvimento desta dissertação. 


\subsection{Objetivos}

O objetivo do trabalho é discutir o planejamento estratégico de transportes com foco na região Centro-Oeste do Brasil, e realizar um exercício simplificado de planejamento estratégico a partir das obras apontadas por programas e planos do governo federal que visam o desenvolvimento do setor.

Como objetivo secundário, espera produzir "massa crítica" focada no desenvolvimento da infraestrutura logística para o escoamento da produção agrícola nacional, enriquecendo, portanto, as discussões sobre o tema. 


\subsection{Estrutura do trabalho}

O presente estudo foi estruturado da seguinte maneira:

Inicialmente, no capítulo 2 serão apresentados conceitos que definem um planejamento estratégico de transportes, ressaltando porque e como deve ser feito e quais os principais objetivos que precisam ser atendidos. Devido a variedade de objetivos, a priorização deles torna-se necessária, e para isso será apresentada uma ferramenta.

O desenvolvimento dos planos recentes realizados no Brasil também é tema de discussão nesse capítulo. O PNLT lançado em 2007 é protagonista juntamente com o Programa de Aceleração do Crescimento (PAC) desse item e terá seu escopo detalhado, indicando os motivos que os distanciam de um planejamento estratégico.

O capítulo 3 apresenta o recente desenvolvimento dos investimentos no setor de transportes, salientando os motivos que o levaram ao abandono verificado nos últimos anos.

A região Centro-Oeste torna- se o foco das análises a partir do capítulo 3.2, onde sua relevância é ressaltada com a descrição da produção atual e o potencial de evolução nos próximos anos.

No capítulo 4 dar-se-á início ao exercício simplificado de planejamento estratégico de transportes. Não se tem a pretensão de realizá-lo por inteiro, em razão da dimensão do trabalho necessário para tanto, mas se pretende mostrar os passos que devem ser seguidos, desde a identificação das necessidades até a priorização das opções disponíveis através de ferramenta específica.

A priorização dos objetivos com definição de indicadores e o cruzamento com as soluções apresentadas em programas de governo também é foco desse capítulo. Com uma metodologia simples, mas robusta, o capítulo apresenta, entre outros, a priorização das principais obras listadas no PNLT e PAC para a região CO.

No capítulo 5, fechando a dissertação, encontram-se as conclusões e algumas recomendações para o desenvolvimento do setor de transportes no Brasil. 
2 Revisão bibliográfica 


\subsection{Planejamento estratégico de transportes}

O planejamento estratégico de transportes tem sido tema de documentos acadêmicos tanto com foco teórico, ou simplesmente com narrativas e análises de experiências pregressas. Dentre as diversas obras consultadas, serão aqui comentadas algumas das mais interessantes e relevantes para 0 trabalho, especialmente aquelas que serviram de alicerce teórico para a composição do exercício simplificado de planejamento estratégico, que compõe o cerne do presente trabalho.

Inicialmente, convém delimitar o conceito de "planejamento estratégico". Segundo Gualda (1995):

O planejamento estratégico de um sistema de transporte tem características de um planejamento de longo prazo, em que se objetiva definir as diretrizes e o dimensionamento do sistema nos horizontes considerados, incluindo as tecnologias a serem empregadas, os investimentos necessários, os retornos esperados, e as etapas de implantação do sistema. Ou seja, corresponde ao desenvolvimento de um plano diretor para o sistema. (Gualda, 1995, p. 30)

Gualda (1995) ainda distingue o planejamento estratégico do tático e do operacional. O planejamento tático "envolve a definição das características do sistema no curto e no médio prazos [...] para o atendimento dos objetivos de curto e de médio prazos do sistema". Sua elaboração presume um esforço estratégico anterior, cujas diretrizes torna-se guias no nível tático.

Já o planejamento operacional "parte da existência de um sistema físico, implantado, e visa à otimização operacional desse sistema. Envolve [...] formas mais eficientes de se oferecer um serviço". É, portanto, uma tarefa de curto e até curtíssimo prazo. Fazendo um breve paralelo com o Programa de Aceleração do Crescimento (PAC), pode-se entender essa "operação emergencial" como uma ação de natureza operacional, de curtíssimo prazo.

No Brasil, o PNLT (2007) é o documento que mais se aproxima de um planejamento estratégico de toda a rede de transportes nacional, como se discute no item 2.2.2. O 
PNLT explicita em seu texto os objetivos e outros elementos que tipicamente integram este tipo de documento.

A rede mundial disponibiliza uma série de outros exemplos de planejamento de transportes aplicados à localidades e países específicos. Dos consultados, o mais completo e de fácil compreensão, é o da Austrália (ATC, 2006) - como será ainda comentado em maiores detalhes.

As revistas científicas que mais publicam tópicos relativos ao planejamento estratégico do setor de transportes são a Transport Policy (particularmente) e a Journal of Transport Geography. Outras revistas mundialmente renomadas do setor, como a Transportation Research (volumes A a E) e a Transportation Science, focam suas publicações nos níveis tático e operacional. Em outras palavras, nestas últimas são usuais os artigos sobre métodos de otimização e heurísticas aplicadas a problemas de transporte como roteamento e localização, análises quantitativas de eficiência como a de envoltória de dados, entre outros. Pouco se vê, todavia, artigos referentes às metodologias de planejamento de transporte num nível estratégico.

O planejamento estratégico de um sistema de transportes - seja ele nacional, regional, rural ou urbano - não é uma tarefa simples. Muito além de aspectos técnicos, ele contempla decisões políticas de instâncias superiores do governo. Deve também enfrentar questões ambientais, de acessibilidade e igualdade social, entre outros. O planejamento estratégico de transportes afeta, e é afetado, por todo o contexto social e econômico da região em questão.

Para um desafio tão complicado, e cuja realização envolve tantas dimensões, Kölbl, et al., (2008) propuseram uma estrutura genérica de planejamento estratégico e a aplicaram ao setor de transportes. A estrutura também contempla o aspecto dinâmico do processo de planejamento, prevendo mecanismos de feedback. $\mathrm{O}$ framework proposto atenderia, segundo os autores, as perspectivas de abordagem comumente empregadas com este propósito:

- Orientada à tomada de decisão a partir de uma "visão", do "planejamento" ou por "consenso" (perspectivas explicadas mais adiante);

- Orientada à definição de objetivos, problemas, indicadores, metas, etc.;

- Orientada à participação pública; ou 
- A partir de um conjunto de ferramentas de planejamento.

Para que apenas uma estrutura possa contemplar todas essas possíveis abordagens, deve ser ao mesmo tempo simples (sem ser simplista) e objetivo (sem perder o rigor metodológico).

A estrutura proposta resulta da congregação de dois conceitos: ciclo de controle e sistema hierárquico.

O sistema de controle padrão é composto pelos seguintes elementos:

- Objetivos ("objectives", "aims"): são os objetivos do planejamento, definidos não internamente, mas externamente ao sistema de controle';

- Resultados ("outcomes"): são os resultados de um ciclo do processo de planejamento;

- Objetivos ajustados ("adjusted aims"): reproduzem a variação entre os resultados esperados (objetivos) e os realizados (resultados);

- Políticas e regulamentos ("policies, regulations"): mais genericamente, são as ações ou diretrizes estabelecidas pelos governantes (no sentido amplo da palavra). Têm função de controle e geram os instrumentos e medidas;

- Instrumentos e medidas ("instrument, measure"): pode ser concebida como a implantação prática das políticas e regulamentos;

- Barreiras ("barriers"): obstáculos que impedem a plena implantação de dada política e regulamento para atingir o objetivo definido. Neste contexto, pode ser de natureza legal/institucional, tecnológica, etc.;

- Indicadores de sistema ("system indicators"): métricas usadas para quantificar os objetivos, permitindo avaliar o desempenho estratégico em comparação a valores benchmark e direções e prazos estabelecidos; e

- Feedback: consiste nos resultados atingidos em cada ciclo, e permite a realimentação do ciclo de planejamento e o seu monitoramento.

\footnotetext{
${ }^{1}$ Se os objetivos são definidos internamente, pode-se gerar um sistema de feedback positivo, que se realimentam, levando a crescimentos ilimitados. Loopings negativos, por outro lado, se auto-corrigem. Segundo Sterman (2000), todos os sistemas, independentemente da complexidade, são compostos por loops negativos e positivos, e toda a dinâmica decorre das interações cruzadas entre esses loops.
} 
A Figura 1 mostra o inter-relacionamento destes elementos.

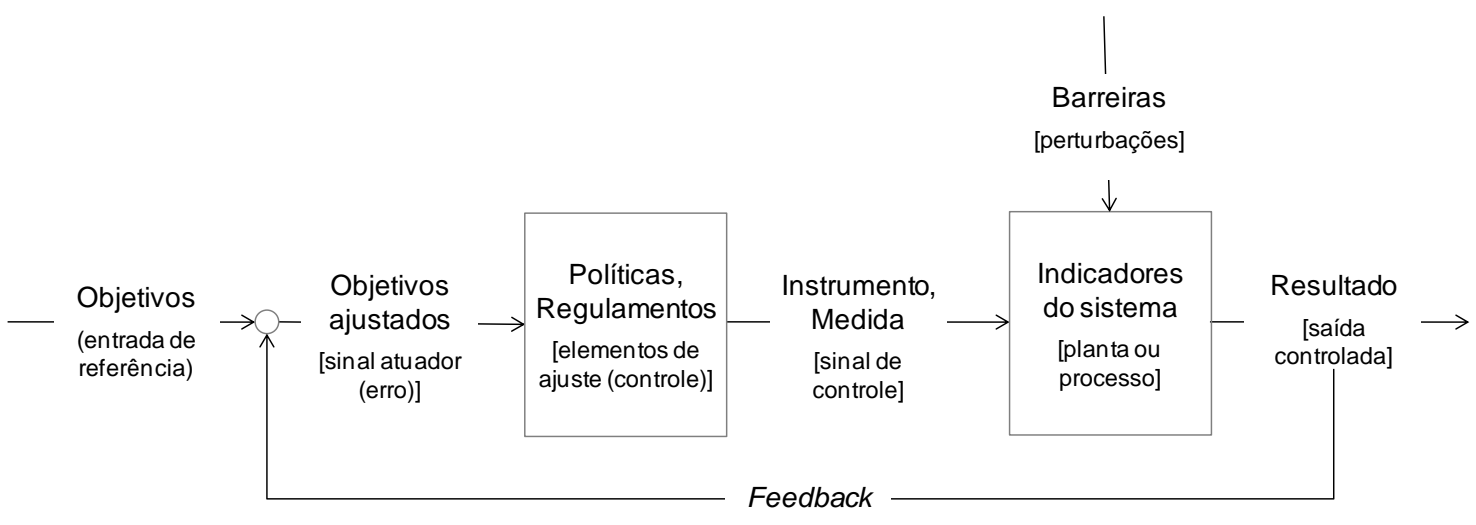

Figura 1: Looping de feedback de planejamento estratégico e terminologia padrão da teoria de controle (em colchetes). Fonte: Kölbl, Niegl e Knoflacher (2008)

O conceito de sistema hierárquico, utilizado pelos autores, está relacionado à fragmentação de um conceito amplo em partes menores, mais simples, facilitando o tratamento de problemas complexos.

Para justificar o uso da hierarquia o autor remete ao conceito de "emergência", tal qual definido no artigo e em Wikipedia $(2010)^{2}$. Uma estrutura de natureza qualquer, mais ampla, é sucessivamente decomposta em partes, de forma a se obter relações simples. São destas incontáveis relações simples que emergem sistemas complexos.

Da conjugação destes dois conceitos - sistema de controle e sistema hierárquico emerge a "matriz de planejamento estratégico", apresentada na Tabela 1.

\footnotetext{
${ }^{2}$ Fonte: http://en.wikipedia.org/wiki/Emergence.
} 
Tabela 1: Matriz de planejamento estratégico. Fonte: Kölbl, Niegl e Knoflacher (2008)

\begin{tabular}{|c|c|c|c|c|c|}
\hline \multirow{2}{*}{\multicolumn{2}{|c|}{ Sistema hierárquico }} & \\
\hline & & $\begin{array}{c}\text { Objetivos } \\
\text { QUALITATIVO }\end{array}$ & \multicolumn{2}{|c|}{$\begin{array}{l}\text { Políticas Instrumentos } \\
\text { Pes controle }\end{array}$} & $\begin{array}{c}\text { Indicadores } \\
\text { QUANTITATIVO }\end{array}$ \\
\hline $\begin{array}{l}0 \\
\stackrel{x}{1} \\
0 \\
\vdots \\
\Sigma\end{array}$ & Nível 1 & $\begin{array}{l}\text { Objetivo 1,1 } \\
\ldots \\
\text { Objetivo 1, n }\end{array}$ & $\begin{array}{c}\text { Política } 1,1 \\
\ldots \\
\text { Política 1, n }\end{array}$ & $\begin{array}{c}\text { Medida 1,1 } \\
\text { Medida 1, n }\end{array}$ & $\begin{array}{c}\text { Indicador } 1,1 \\
\quad \ldots \\
\text { Indicador } 1, \mathrm{n}\end{array}$ \\
\hline & Nível 2 & $\begin{array}{l}\text { Objetivo } 2,2 \\
\ldots \\
\text { Objetivo } 2, \mathrm{n}\end{array}$ & $\begin{array}{c}\text { Política 2,2 } \\
\quad \ldots \\
\text { Política 2, n }\end{array}$ & $\begin{array}{c}\text { Medida 2,2 } \\
\ldots \\
\text { Medida 2, n }\end{array}$ & $\begin{array}{c}\text { Indicador 2,2 } \\
\quad \ldots \\
\text { Indicador 2, n }\end{array}$ \\
\hline & $\ldots$ & $\ldots$ & $\ldots$ & $\ldots$ & $\ldots$ \\
\hline $\begin{array}{l}\stackrel{0}{\stackrel{N}{0}} \\
\stackrel{0}{\Sigma}\end{array}$ & Nível N & $\begin{array}{l}\text { Objetivo n,n } \\
\ldots \\
\text { Objetivo n, n }\end{array}$ & $\begin{array}{c}\text { Política } n, n \\
\ldots \\
\text { Política n, n }\end{array}$ & $\begin{array}{c}\text { Medida n,n } \\
\ldots \ldots \\
\text { Medida n, n }\end{array}$ & $\begin{array}{l}\text { Indicador n,n } \\
\ldots \\
\text { Indicador n, n }\end{array}$ \\
\hline
\end{tabular}

A consistência no planejamento deve ser atingida nas duas direções. Na vertical, os objetivos, políticas, medidas e indicadores num determinado nível devem se configurar como "partes" dos elementos de mesmo tipo do nível superior (segundo o sistema hierárquico). Na horizontal, em cada nível deve se assegurar o alinhamento dos objetivos, políticas, medidas e indicadores. Esse framework, alegam os autores, é aplicável a sistemas complexos de qualquer natureza, incluindo transportes.

A despeito da riqueza conceitual, este material não lança luz sobre a decisão de como definir objetivos, políticas, medidas e indicadores nos determinados níveis apenas de como estruturá-los e garantir a consistência no processo de planejamento estratégico. Neste quesito, um dos documentos mais referenciados atualmente (Emberger, et al, 2009) é aquele elaborado pela União Europeia em 2003, denominado "Procedures for Recommending Optimal Sustainable Planning of European City Transport Systems - PROSPECTS". Embora focado em planejamento estratégico de transporte em regiões urbanas, suas diretrizes genéricas aplicam-se a sistemas de transportes em outros contextos.

O PROSPECTS investigou os processos de tomada de decisão em nível estratégico em toda a Europa, incorporou estudos anteriores e desenvolveu diretrizes para um 
processo "ideal" num contexto europeu de transporte urbano. Seus principais pontos estão descritos no “Decision Makers Guidebook - DMG” (May et al, 2005).

O DMG aponta três abordagens gerais para o processo de tomada de decisão para o setor de transportes (em princípio aplicáveis a outros setores de interesse público): guiada por visão ("vision-led"), guiada por planejamento ("plan-led") e guiada por consenso ("consensus-led"). Todas têm suas armadilhas, como identifica a Tabela 2.

Tabela 2: Descrição e armadilhas das abordagens para tomadas de decisão estratégicas, segundo o DMG. Fonte: May et al, (2005)

\begin{tabular}{|c|c|c|}
\hline $\begin{array}{l}\text { Abordagem de } \\
\text { planejamento }\end{array}$ & Descrição & Armadilhas \\
\hline $\begin{array}{l}\text { Guiada por } \\
\text { visão }\end{array}$ & $\begin{array}{l}\text { Envolve uma percepção de futuro e } \\
\text { impulso de ação de um líder ou grupo } \\
\text { de liderança, que tenha a capacidade } \\
\text { de desenvolver políticas e } \\
\text { instrumentos necessários para se } \\
\text { atingir a visão }\end{array}$ & $\begin{array}{l}\text { Dependente, em geral, de uma } \\
\text { pessoa ou pequeno grupo. } \\
\text { Caso esta pessoa ou grupo } \\
\text { deixe o serviço, a visão se } \\
\text { perde (como frequentemente } \\
\text { observado) }\end{array}$ \\
\hline $\begin{array}{l}\text { Guiada por } \\
\text { planejamento }\end{array}$ & $\begin{array}{l}\text { Envolve a especificação de objetivos } \\
\text { e problemas, a adoção de } \\
\text { procedimentos que permitam } \\
\text { conceber soluções para estes } \\
\text { problemas e selecionar a melhor } \\
\text { opção. Envolve em geral o uso de } \\
\text { ferramentas formais de avaliação, } \\
\text { como de análises de custo-benefício } \\
\text { ou de análises multicritério (por } \\
\text { exemplo, a Analytic Hierarchy } \\
\text { Process- } A H P \text { ) }\end{array}$ & $\begin{array}{l}\text { Pode ser excessivamente } \\
\text { dependente de planejadores } \\
\text { profissionais e perder a noção } \\
\text { dos objetivos das } \\
\text { necessidades da sociedade } \\
\text { em geral, especialmente } \\
\text { grupos menos favorecidos }\end{array}$ \\
\hline $\begin{array}{l}\text { Guiada por } \\
\text { consenso }\end{array}$ & $\begin{array}{l}\text { Parte de discussões entre os agentes } \\
\text { interessados para se chegar a um } \\
\text { consenso em cada passo do } \\
\text { processo geral de planejamento } \\
\text { (objetivos e priorização, problemas } \\
\text { prioritários, instrumentos, etc.) }\end{array}$ & $\begin{array}{l}\text { A demora em se chegar aos } \\
\text { consensos pode levar a } \\
\text { atrasos inaceitáveis }\end{array}$ \\
\hline
\end{tabular}

Em 2003, segundo o DMG, as abordagens guiadas por planejamento e por consenso eram a maioria na Europa, 44\%, seguidas por planejamento e visão, com $22 \%$. Em $71 \%$ dos casos a abordagem guiada por planejamento foi utilizada (em conjunto com outra ou não). O DMG recomenda, para a maior parte das situações, o uso de uma combinação das três abordagens, com o ajuste exato dependendo das circunstâncias. 
No caso de um processo de tomada de decisão puramente guiado por planejamento (e apenas para este caso), Emberger, et al, (2009) aponta o que seria um processo "ideal". Os passos são retratados na Figura 2:

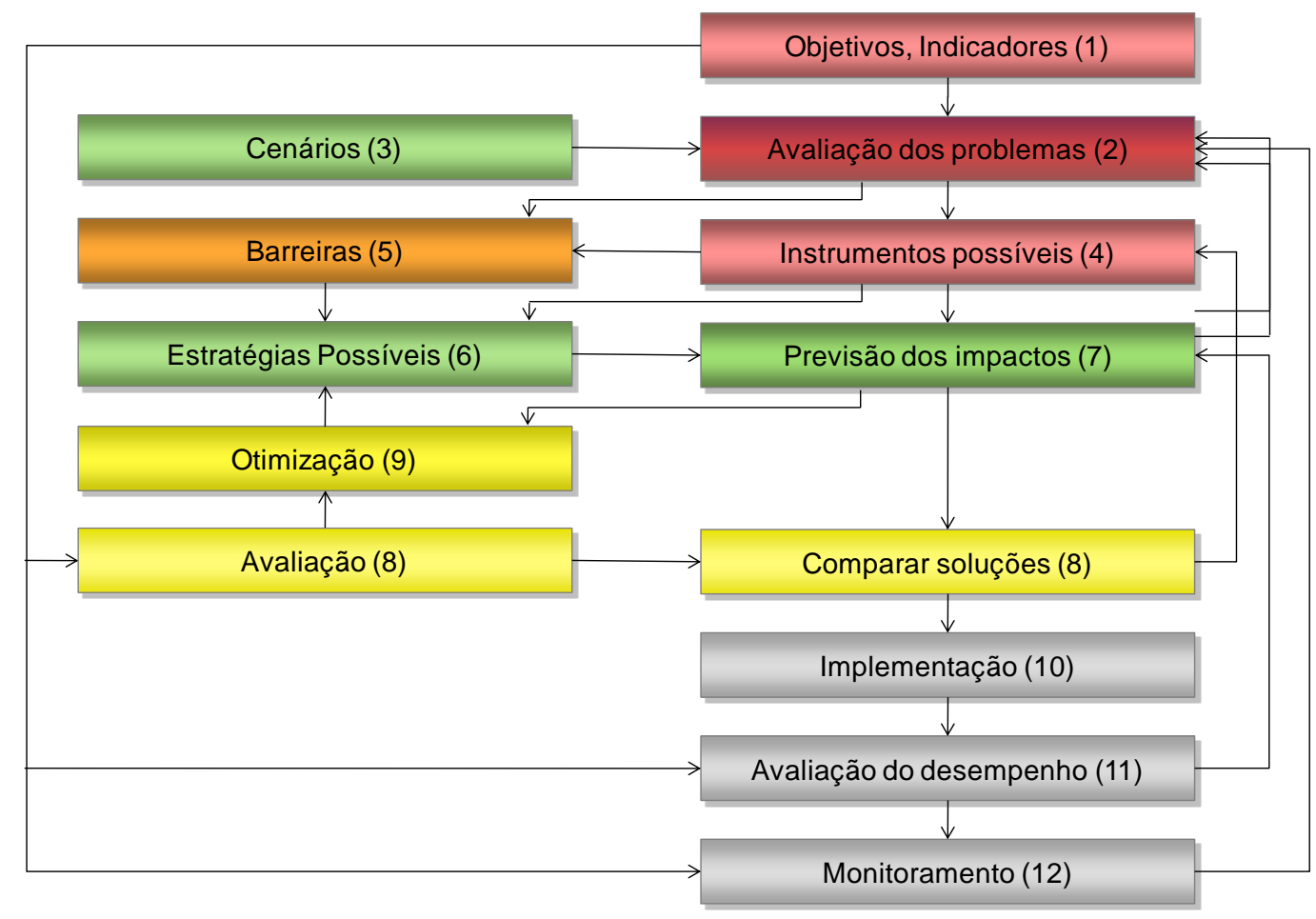

Figura 2: Processo "ideal" de tomada de decisão na abordagem guiada por planejamento.

Fonte: Emberger, et al, (2009)

Esta abordagem "ideal" soa um pouco "confusa" à primeira vista, porém ela pode ser de certa forma lida como uma especificação do sistema de controle proposto por Kölbl, Niegl e Knoflacher (2008), muito embora com "subciclos" de feedback. Os objetivos, políticas, instrumentos e indicadores seriam contemplados pelas etapas (1) a (4) acima. As barreiras ou perturbações pela etapa (5). O reconhecimento dos resultados de um ciclo do planejamento estaria relacionado as etapas (6) e (7) onde se obtém as estratégias possíveis e seus impactos. O feedback do processo, incluindo a avaliação dos resultados, do desempenho, e seu monitoramento, está relacionado às etapas (8) a (12).

O exercício simplificado de planejamento desenvolvido nesta dissertação adota uma abordagem guiada por visão e por planejamento. Recebe como input obras concebidas pelo PNLT e constantes no PAC, e as trata de forma planejada. 
Das obras previstas no PNLT, algumas foram introduzidas a partir do diagnóstico realizado da infraestrutura logística brasileira e das demandas previstas, com uso de técnicas de simulação. Outras o PNLT tomou de projetos anteriores, concebidos em geral em processos visionários sugeridos por aspectos naturais, como a calha de grandes rios. Já as obras de logística constantes no PAC foram de caráter emergencial e iniciativas de políticos ou grupos de interesse, e foram integradas com base em critérios políticos junto as outras.

Como frisado anteriormente, a aplicação destes ou de outros frameworks similares, no processo de planejamento estratégico, não é uma tarefa fácil. A complexidade dos fatores que devem ser incorporados leva à dificuldade de estruturação do problema e identificação e execução das soluções.

À luz desta constatação, problemas que serão descritos mais adiante nesta dissertação, referentes ao caso brasileiro, já foram verificados e analisados em outras partes do mundo.

Tome-se o seguinte exemplo relatado na literatura. Richardson e Haywood (1996), ao avaliarem os motivos do fracasso do planejamento estratégico do sistema de transporte terrestres na região dos Montes Peninos, no Reino Unido, na década de 90, ressaltaram a falta de uma "avaliação normativa". As questões normativas são aquelas externas ao problema em si, mas cuja influência determina os resultados da política a ser planejada e implantada. São aspectos políticos, econômicos e sociais, ligados aos diferentes interesses dos stakeholders, que interferem no processo de planejamento estratégico por meio de lobbies, restrição de acesso aos processos decisórios, entre outros. Segundo os autores: "Nos Peninos, as decisões finais sempre seriam determinadas politicamente, quiçá validadas, porém nunca desafiadas em um exercício de modelagem de transportes" [tradução do autor]. 0 artigo permite uma noção clara das implicações de uma má formulação de um processo guiado tanto por planejamento como por consenso.

Além da falta de consideração dos aspectos citados, problemas como o uso de diferentes metodologias para avaliar as necessidades de transporte rodoviário e ferroviário e a falta de devida incorporação dos aspectos ambientais no processo (numa região claramente sensibilizada), de forma arbitrária, minaram o processo de 
planejamento estratégico, que resultou na decisão do governo de nada implantar. Gastou-se tempo e recursos, e não se resolveu o problema.

Em outro exemplo, Kölbl, Niegl e Knoflacher (2008) avaliam quatro esforços de planejamento estratégico de transportes:

- “Austria - General Transport Plan 2002" (Áustria);

- "The German Bundesverkehrswegeplan 2003" (Alemanha);

- "Der Sachplan Schiene/öV 2002" e "Der Sachplan Straße 2002" (Suiça); e

- "The European Union White Paper on Transport 2001" (União Europeia).

Nesta avaliação, os autores identificam os elementos da matriz que propuseram (Tabela 1) nestes documentos de planejamento e avaliam se há lacunas, considerando:

- Nas linhas (áreas ou domínios):

- Nível 1: Ambiente:

- Nível 2: Atmosfera, resíduos sólidos, recursos biológicos, matérias primas e combustíveis;

- Nível 1: Sociedade:

- Nível 2: Segurança física, seguridade social, justiça social, saúde;

- Nível 1: Economia:

- Nível 2: Modicidade de preços, pesquisa e desenvolvimento, finanças públicas, indústrias e provedores de serviço, consumidores;

- Nas colunas (etapas do processo de planejamento):

- Objetivos ("objectives");

- Medidas/ políticas (“measures");

○ Indicadores ("indicators").

Resulta dessa avaliação a Tabela 3. Foram colocadas as etapas do processo efetivamente realizadas em cada caso. Onde não houve clareza ou alocação errada (por exemplo, colocar uma medida como se fosse um objetivo), o item foi desconsiderado. Desta forma, a tabela apresenta as etapas que se apresentam de forma clara para os interessados. 
Tabela 3: Etapas de processos de planejamento de transportes realizados na Europa entre 2001 e 2003. Fonte: Kölbl, Niegl e Knoflacher (2008)

\begin{tabular}{|c|c|c|c|c|c|c|c|c|c|c|c|c|}
\hline \multirow{2}{*}{ Área\País } & \multicolumn{3}{|c|}{ Áustria } & \multicolumn{3}{|c|}{ Alemanha } & \multicolumn{3}{|c|}{ Suíça } & \multicolumn{3}{|c|}{$\begin{array}{l}\text { União } \\
\text { Europeia }\end{array}$} \\
\hline & 0 & $\mathbf{M}$ & $\mathbf{I}$ & 0 & M & $\mathbf{I}$ & 0 & $\mathbf{M}$ & I & 0 & $\mathbf{M}$ & I \\
\hline \multicolumn{13}{|l|}{ Ambiente } \\
\hline Atmosfera & & & & $x$ & & & $x$ & $x$ & $x$ & & & \\
\hline Resíduos sólidos & & & & $x$ & & & $x$ & $x$ & & & & \\
\hline Recursos biológicos & & & & $x$ & & & $x$ & $x$ & & & & \\
\hline Matérias primas & $x$ & & & $x$ & & & & & & & & \\
\hline Combustíveis & & & & $x$ & & & $x$ & $x$ & & & & \\
\hline \multicolumn{13}{|l|}{ Sociedade } \\
\hline Segurança física & $x$ & & & $x$ & & & $x$ & $x$ & $x$ & $x$ & $x$ & $x$ \\
\hline Seguridade social & & & & & & & $x$ & $x$ & & & & \\
\hline Justiça social & & & & & & & $x$ & & & & & \\
\hline Saúde & & & & $x$ & & & $x$ & $x$ & & & & \\
\hline \multicolumn{13}{|l|}{ Economia } \\
\hline Modicidade de preços & $x$ & $x$ & $x$ & $x$ & $x$ & $x$ & $x$ & $x$ & $\mathbf{x}$ & $x$ & $x$ & \\
\hline Pesquisa e desenvolvimento & & & & $x$ & & & $x$ & $x$ & & & $x$ & \\
\hline Finanças públicas & $x$ & & & $x$ & & & $x$ & $x$ & & & & \\
\hline \multicolumn{13}{|l|}{$\begin{array}{l}\text { Indústrias e prestadores de } \\
\text { serviço }\end{array}$} \\
\hline Consumidores & & & & & & & & & & & & \\
\hline
\end{tabular}

Sendo irrelevante neste contexto comparar os quatro estudos acima, cabe ressaltar algumas impressões gerais. Primeiro: deu-se maior atenção, em geral, à proposição de objetivos do que à proposição de medidas. Esta, por sua vez, teve maior atenção que a proposição de indicadores. Isto representa uma dificuldade em traduzir, para níveis inferiores e mais "quantitativos", sensibilidades bem traduzidas nos objetivos gerais, qualitativos.

Segundo: os aspectos econômicos foram contemplados com maior frequência que os demais. Esta percepção é coerente com a de Richardson e Haywood (1996), que acusaram para o caso por eles avaliado: "Críticas fundamentais do estudo [...] falta de integração com os aspectos ambientais" [tradução do autor]. Uma predileção por 
estes aspectos em detrimento de outros, como os sociais, por exemplo, podem levar a conflitos de interesse políticos que emperram o desenvolvimento do setor.

$\mathrm{Na}$ rede mundial estão também disponibilizados, além de documentos de caráter acadêmico, guias e relatórios de planejamento estratégico de transportes de países e regiões do globo. Além do PNLT e do DMG, já citados, cabe comentar o "National Guidelines for Transport System Management in Australia" (ATC, 2006).

Neste documento apresenta-se em detalhes a estrutura do processo e a metodologia empregada em cada fase, revelando a complexidade e extensão do trabalho. ATC (2006) utilizou um framework bastante amplo de planejamento de transportes em oito fases, que se inicia no reconhecimento dos objetivos estratégicos amplos do governo e da sociedade da região em discussão, e culmina com a revisão do desempenho do planejamento (Figura 3).

\begin{tabular}{|c|c|c|c|c|c|c|c|}
\hline $\begin{array}{l}\text { 1. Definição de } \\
\text { Objetivos } \\
\text { - Objetivos do } \\
\text { governo/sociais } \\
\text { - Objetivos do } \\
\text { sistema de } \\
\text { transportes } \\
\text { - Indicadores de } \\
\text { desempenho e } \\
\text { metas }\end{array}$ & $\begin{array}{l}\text { 2. Escolha de } \\
\text { políticas } \\
\text {-Definição de } \\
\text { diretrizes } \\
\text { governamentais } \\
\text {-Decisões de } \\
\text { políticas de } \\
\text { transportes }\end{array}$ & $\begin{array}{l}\text { 3. Planejamento } \\
\text { estratégico do } \\
\text { sistema } \\
\text { - Rede multimodal } \\
\text { - Corredores e } \\
\text { áreas } \\
\text { - Rotas e trechos }\end{array}$ & $\begin{array}{l}\text { 4. Iniciativas de } \\
\text { infraestrutura e } \\
\text { superestrutura } \\
\text { - Oriundo de: } \\
\text { oPolíticas e } \\
\text { planejamento do } \\
\text { sistema } \\
\text { oOutras áreas do } \\
\text { governo } \\
\text { oSetor privado } \\
\text { oProcesso político }\end{array}$ & $\begin{array}{l}\text { 5. Avaliação das } \\
\text { iniciativas } \\
\text {-Teste de mérito } \\
\text {-Avaliação rápida } \\
\text {-Avaliação } \\
\text { detalhada }\end{array}$ & $\begin{array}{l}\text { 6. Priorização de } \\
\text { iniciativas e } \\
\text { elaboração do } \\
\text { plano } \\
\text {-Identificação de } \\
\text { iniciativas } \\
\text { prioritárias } \\
\text {-Desenvolvimento } \\
\text { do plano } \\
\text {-Decisão ministerial }\end{array}$ & $\begin{array}{l}\text { 7. Implantação } \\
\text { do plano } \\
\text {-Implantação de } \\
\text { iniciativas } \\
\text { aprovadas e/ou } \\
\text { financiadas }\end{array}$ & $\begin{array}{l}\text { 8. Exame do } \\
\text { desempenho } \\
\text {-Resultados reais } \\
\text { vs. esperados } \\
\text {-Eficácia das } \\
\text { iniciativas, planos, } \\
\text { estratégias } \\
\text {-Eficiência do } \\
\text { framework }\end{array}$ \\
\hline
\end{tabular}

Figura 3: Framework do planejamento de transportes na Austrália discutido em ATC (2006)

A Tabela 4 apresenta as relações entre as fases citadas. 
Tabela 4: Inputs, processos, análises e outputs das fases de planejamento propostas por ATC (2006)

\begin{tabular}{|c|c|c|c|}
\hline Fase & Inputs & Processos e análises & Outputs \\
\hline 1 & $\begin{array}{l}\text { Objetivos do governo } \\
\text { e sociedade; } \\
\text { Feedbacks de outras } \\
\text { fases }\end{array}$ & $\begin{array}{l}\text { Processos de tomada de decisão do } \\
\text { governo }\end{array}$ & Objetivos do sistema de transporte \\
\hline 2 & $\begin{array}{l}\text { Outputs da fase } 1 ; \\
\text { Feedbacks de outras } \\
\text { fases }\end{array}$ & $\begin{array}{l}\text { Análises de opções; } \\
\text { Estudos de políticas públicas; } \\
\text { Análises de demanda; } \\
\text { Estudos de infraestrutura; } \\
\text { Planejamento de transportes e de uso do } \\
\text { solo }\end{array}$ & $\begin{array}{l}\text { Decisões de política de transportes de } \\
\text { alto nível; } \\
\text { Indicadores de desempenho do sistema } \\
\text { de transportes e metas }\end{array}$ \\
\hline 3 & $\begin{array}{l}\text { Outputs da fase } 2 \\
\text { Feedbacks de outras } \\
\text { fases }\end{array}$ & $\begin{array}{l}\text { Análises de opções; } \\
\text { Avaliações da rede existente; } \\
\text { Revisões da literatura; } \\
\text { Estudos das áreas e dos corredores } \\
\text { multimodais; } \\
\text { Análises de demanda; } \\
\text { Análises de cenários }\end{array}$ & $\begin{array}{l}\text { Rede multimodal; } \\
\text { Objetivos, indicadores e metas da rede; } \\
\text { Estratégias da rede multimodal; } \\
\text { Definição das áreas e corredores; } \\
\text { Estratégias das áreas e corredores; } \\
\text { Definição das rotas e trechos; } \\
\text { Objetivos, indicadores e metas das rotas } \\
\text { e trechos; } \\
\text { Planos de rotas e trechos }\end{array}$ \\
\hline 4 & $\begin{array}{l}\text { Outputs da fase } 3 ; \\
\text { Feedbacks de outras } \\
\text { fases }\end{array}$ & $\begin{array}{l}\text { Iniciativas do planejamento estratégico; } \\
\text { Outras fontes de iniciativas (outras } \\
\text { agências, setor privado, etc.) }\end{array}$ & Lista de iniciativas identificadas \\
\hline 5 & $\begin{array}{l}\text { Outputs da fase } 4 \\
\text { Feedbacks de outras } \\
\text { fases }\end{array}$ & $\begin{array}{l}\text { Análises de opções; } \\
\text { Avaliação das iniciativas (avaliações } \\
\text { rápidas e detalhadas) }\end{array}$ & $\begin{array}{l}\text { Relatórios de avaliação das iniciativas; } \\
\text { Estudo de caso para cada iniciativa }\end{array}$ \\
\hline 6 & $\begin{array}{l}\text { Outputs da fase } 5 \text {; } \\
\text { Feedbacks de outras } \\
\text { fases }\end{array}$ & $\begin{array}{l}\text { Determinação de investimentos prioritários; } \\
\text { Priorização de iniciativas; } \\
\text { Aprovação do plano }\end{array}$ & $\begin{array}{l}\text { Plano de iniciativas ( } 3-5 \text { anos); } \\
\text { Iniciativas firmes ( } 1 \text { ano); } \\
\text { Indicativos de iniciativas ( } 3-5 \text { anos) }\end{array}$ \\
\hline 7 & $\begin{array}{l}\text { Outputs da fase } 6 ; \\
\text { Feedbacks de outras } \\
\text { fases }\end{array}$ & $\begin{array}{l}\text { Planejamento detalhado de implantação } \\
\text { das iniciativas; } \\
\text { Gestão do orçamento; } \\
\text { Gestão das iniciativas; } \\
\text { Seleção do mecanismo de implantação }\end{array}$ & $\begin{array}{l}\text { Iniciativas implantadas; } \\
\text { Desempenho atual do sistema }\end{array}$ \\
\hline 8 & Outputs da fase 7 & $\begin{array}{l}\text { Avaliação das iniciativas pós-conclusão; } \\
\text { Auditoria do plano; } \\
\text { Revisão dos resultados (desempenho real } \\
\text { vs. realizado); } \\
\text { Revisão do framework }\end{array}$ & $\begin{array}{l}\text { Feedbacks para aprimorar sistema de } \\
\text { transporte; } \\
\text { Mudanças propostas ao framework; } \\
\text { Lições para o futuro }\end{array}$ \\
\hline
\end{tabular}

Trata-se certamente de uma descrição completa de um processo de planejamento estratégico de transportes, sendo que as fases podem ser unidas em três grupos:

- Planejamento estratégico orientado por objetivos: fases 1 a 3;

- Avaliação e desenvolvimento do plano: fases 4 a 6; e

- Implantação e exame de desempenho: fases 7 e 8.

Faz-se aqui um oportuno parêntese para comentar sobre a metodologia a ser aplicada no exercício simplificado deste trabalho de mestrado. O processo descrito 
em ATC (2006), que segue os princípios gerais de planejamento estratégico investigados por Kölbl, Niegl e Knoflacher (2008), foi utilizado como base para o exercício descrito no capítulo 4.

Não obstante, o exercício não incorpora uma série de elementos de um processo completo de planejamento estratégico de transportes, conforme comentado até o momento. Mais precisamente, o trabalho contempla basicamente a fase 1 (ao definir objetivos estratégicos para o sistema de transportes em questão, e priorizá-los), a fase $2^{3}$ (ao assumir que a política para solução das questões tratadas será a de expansão da infraestrutura de transporte existente), a fase 4 (ao levantar as obras de infraestrutura de transporte consideradas), a fase 5 (ao avaliar estas obras) e a fase 6 (ao determinar as obras prioritárias). Nesta dissertação, estas fases não são desenvolvidas com toda a complexidade que a aplicação real exige.

Voltando ao documento de ATC (2006), no que diz respeito aos níveis do planejamento, para os quais se estabelece objetivos, medidas, etc., são considerados os seguintes elementos:

- Trechos ou ligações ("links"): Partes de rotas. Podem ser também ponto de transbordo - locais onde acontece a mudança de modais;

- Rotas ("routes"): Trajeto que conecta dois pontos utilizando um único modal;

- Corredores ("corridors"): Rotas que conectam dois pontos, podendo ser multimodal ou operado por um único modal;

- Áreas ("areas"): Local geográfico definido e todas as rotas nele contidas; e

- Redes ("networks"): Incorpora todos os corredores que interligam diferentes áreas, podendo ser multimodal ou de um único modal. Exemplos de rede incluem a rede nacional de transporte terrestre de um país e a rede urbana de uma cidade.

\footnotetext{
${ }^{3}$ Parte-se da premissa que os sistemas de transporte que hoje servem a produção agrícola do Centro-Oeste brasileiro estão saturados, e, portanto, outras políticas (tais como incentivos ao processamento das commodities in loco, ao aumento dos lotes médios, etc.), seriam virtualmente inócuos.
} 


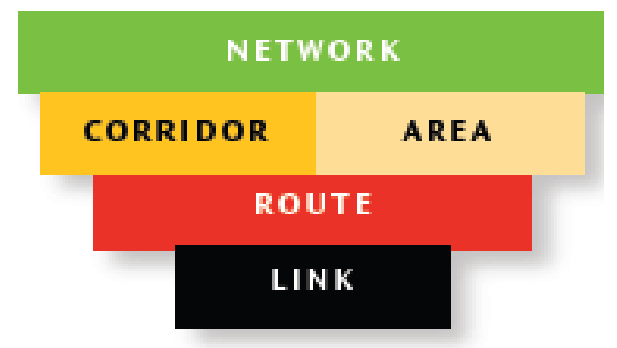

Figura 4: Elementos do sistema de transportes. Fonte: ATC (2006)

A figura acima expressa a relação hierárquica existente entre estes elementos. Como pregam Kölbl, Niegl e Knoflacher (2008), a relação impõe um alinhamento dos objetivos, medidas e indicadores entre os diferentes níveis, o que também é explicitado no próprio documento australiano ${ }^{4}$. Para um objetivo macro de "segurança" estabelecido na fase 1, por exemplo, garante-se a consistência da seguinte forma:

Tabela 5: Exemplos de alinhamento de objetivos nos diferentes níveis. Fonte: ATC (2006)

\begin{tabular}{|l|l|}
\hline \multicolumn{1}{|c|}{ Nível do objetivo } & \multicolumn{1}{c|}{ Exemplos } \\
\hline Sociedade/ governo central & Segurança pública \\
\hline Sistema de transporte & $\begin{array}{l}\text { Segurança no sistema de transporte do estado } \\
\text { X }\end{array}$ \\
\hline Rede & $\begin{array}{l}\text { Redução de mortalidade no sistema de } \\
\text { transporte da cidade } \mathrm{Y}\end{array}$ \\
\hline Corredores ou áreas & $\begin{array}{l}\text { Redução da taxa de mortalidade no corredor ou } \\
\text { área Z }\end{array}$ \\
\hline Rotas & $\begin{array}{l}\text { Redução da taxa de mortalidade na rua A no } \\
\text { corredor ou área Z }\end{array}$ \\
\hline Trechos & $\begin{array}{l}\text { Redução da taxa de mortalidade na rua A entre } \\
\text { os marcos M e N }\end{array}$ \\
\hline
\end{tabular}

Deste modo, percebe-se que as essências do esforço de planejamento ora em discussão e a matriz de planejamento estratégico proposta na Tabela 1 possuem características similares. Também é possível traçar semelhanças entre o processo

\footnotetext{
${ }^{4}$ Ao tratar com atenção de elementos menores como rotas ou trechos, o trabalho perde um pouco o caráter de "estratégico".
} 
desenvolvido por ATC (2006) e aquele desenhado por Emberger, et al. (2009), mostrado na Figura 2.

Os temas usualmente abordados para delinear os objetivos e metas do planejamento estratégico de transportes recaem em aspectos econômicos, sociais e ambientais. São justamente estes os três itens tratados na fase 1 em ATC (2006):

- Os objetivos econômicos incluem o aumento dos níveis de renda e de prosperidade, a criação de empregos, o fomento do desenvolvimento econômico, por meio do comércio e da exportação, entre outros;

- Podem ser estipulados como objetivos sociais a melhor distribuição de renda, o acesso adequado aos serviços de interesse público (também conhecido pelo termo "universalidade"), e a equidade (ou seja, o tratamento igual a todos os usuários do serviço; e

- Os objetivos ambientais englobam a proteção do meio-ambiente e da cultura local, e podem estar relacionadas ao desejo de viver em locais sem poluição, à preocupação com as gerações futuras e ao reconhecimento do valor do meio ambiente.

Como exemplo de medidas para consecução dos objetivos econômicos pode-se citar, por exemplo, a diminuição do tempo de viagem ou a diminuição dos valores médios de fretes terrestres. Já os objetivos sociais podem ser atingidos, por exemplo, a partir da melhoria da acessibilidade a áreas rurais. Por fim, são exemplos de medidas ambientais a diminuição da emissão de gases que agravam o efeito estufa e a redução de ruídos.

Após a escolha dos objetivos de interesse, deve-se estabelecer uma ordem de prioridade entre eles. Isso ajudará em tomadas de decisão em que haja conflito, o que pode ocorrer, por exemplo, com objetivos ambientais e econômicos. O processo de priorização pode ser feito de forma desestruturada ou, preferencialmente, com o auxílio de uma ferramenta específica que permita a avaliação dos interesses mais relevantes com base em múltiplos critérios. Dentre estas ferramentas está a AHP, descrita no item 2.1.1 e aplicada no exercício desta dissertação.

Também reconhecendo o tripé Economia-Sociedade-Meio-Ambiente, Kölbl, Niegl e Knoflacher (2008) propõem objetivos, medidas, instrumentos e indicadores para 
estas três áreas, como mostram as tabelas que seguem. As proposições transcendem os investimentos nos ativos de transporte, e tocam em pontos como regulação, incentivos fiscais, etc.

Tabela 6: Objetivos, medidas/instrumentos e indicadores para o planejamento de transportes para o meio-ambiente. Adaptado de Kölbl, Niegl e Knoflacher (2008)

\begin{tabular}{|c|c|c|}
\hline Objetivos & Medidas/ instrumentos & Indicadores \\
\hline $\begin{array}{l}\text { Extensão o ciclo de vida das } \\
\text { commodities }\end{array}$ & $\begin{array}{l}\text { Aumentar a durabilidade das pistas } \\
\text { e material rodante; } \\
\text { Incentivos fiscais para aumento do } \\
\text { uso dos veículos }\end{array}$ & $\begin{array}{l}\text { Durabilidade (anos); } \\
\text { Número de veículos de tráfego } \\
\text { pesado (veículos/ano) }\end{array}$ \\
\hline Reciclagem & $\begin{array}{l}\text { Uso de materiais com baixo } \\
\text { dispêndio de energia }\end{array}$ & $\begin{array}{l}\text { Porcentagem de produtos } \\
\text { recicláveis na produção dos } \\
\text { veículos (t/veículo) }\end{array}$ \\
\hline $\begin{array}{l}\text { Redução do uso de } \\
\text { combustíveis }\end{array}$ & $\begin{array}{l}\text { Precificação para reduzir consumo } \\
\text { de combustíveis }\end{array}$ & $\begin{array}{l}\text { Distâncias de transporte }(\mathrm{km}) \text {; } \\
\text { Consumo energético }(\mathrm{kJ} / \mathrm{t} . \mathrm{km})\end{array}$ \\
\hline $\begin{array}{l}\text { Aumento do uso } \\
\text { combustíveis renováveis }\end{array}$ & $\begin{array}{l}\text { Desenvolver de motores e } \\
\text { combustíveis alternativos; } \\
\text { Eletricidade de combustíveis } \\
\text { alternativos }\end{array}$ & $\begin{array}{l}\text { Porcentagem de combustíveis } \\
\text { alternativos sobre o total (\%) }\end{array}$ \\
\hline Minimizar uso do solo & $\begin{array}{l}\text { Reduzir o uso de solo para } \\
\text { infraestrutura de transportes; } \\
\text { Uso mais eficiente } \\
\text { infraestruturas de transporte }\end{array}$ & $\begin{array}{l}\text { Uso de solo para transporte } \\
\text { absoluto (ha) e relativo (\%) }\end{array}$ \\
\hline Proteger a biodiversidade & $\begin{array}{l}\text { Reduzir velocidade; } \\
\text { Reduzir volume de tráfego }\end{array}$ & Volun \\
\hline $\begin{array}{l}\text { Reduzir separação de habitats } \\
\text { e efeitos de barreiras }\end{array}$ & $\begin{array}{l}\text { Alinhamento de pistas; } \\
\text { Criar possibilidades suficientes de } \\
\text { cruzamento fora de nível }\end{array}$ & $\begin{array}{l}\text { Relação de alinhamento direto e } \\
\text { desvios (\%); } \\
\text { Tamanho (ha) e distâncias }(\mathrm{km}) \text { de } \\
\text { áreas de compensação }\end{array}$ \\
\hline
\end{tabular}


Tabela 7: Objetivos, medidas/instrumentos e indicadores para o planejamento de transportes para a economia Adaptado de Kölbl, Niegl e Knoflacher (2008)

\begin{tabular}{|c|c|c|}
\hline Objetivos & Medidas/ instrumentos & Indicadores \\
\hline $\begin{array}{l}\text { Implementar o princípio do } \\
\text { "poluiu-pagou" }\end{array}$ & $\begin{array}{l}\text { Incluir externalidades nos cálculos } \\
\text { de custo; } \\
\text { Precificação de veículos e } \\
\text { pedágios em função da } \\
\text { quilometragem }\end{array}$ & $\begin{array}{l}\text { Custos de poluição, barulho, } \\
\text { acidentes, por modal de } \\
\text { transporte; } \\
\text { Tarifa de pedágio em função da } \\
\text { quilometragem }\end{array}$ \\
\hline $\begin{array}{l}\text { Aumentar a eficiência das } \\
\text { finanças públicas em termos } \\
\text { de infraestrutura de transportes }\end{array}$ & $\begin{array}{l}\text { Otimização operacional da } \\
\text { infraestrutura existente }\end{array}$ & $\begin{array}{l}\text { Custos para extensão ou } \\
\text { construção de nova infraestrutura } \\
\text { de transportes; } \\
\text { Comparação de investimentos - } \\
\text { extensão vs. greenfield }\end{array}$ \\
\hline $\begin{array}{l}\text { Aumentar a produção de } \\
\text { produtos e serviços } \\
\text { ecologicamente e socialmente } \\
\text { adequados }\end{array}$ & $\begin{array}{l}\text { Certificação ambiental de produtos } \\
\text { e serviços com a inclusão dos } \\
\text { aspectos de transporte; } \\
\text { Avaliação dos custos de transporte } \\
\text { dos produtos }\end{array}$ & $\begin{array}{l}\text { Número de unidades de produção } \\
\text { certificadas por área ou região; } \\
\text { Distância percorrida por unidade } \\
\text { de produto }\end{array}$ \\
\hline $\begin{array}{l}\text { Aumentar a informação dos } \\
\text { produtos quanto aos padrões } \\
\text { de transporte }\end{array}$ & $\begin{array}{l}\text { Implementar informação do } \\
\text { transporte na descrição dos } \\
\text { produtos (embalagens); } \\
\text { Recomendar "padrões ecológicos" } \\
\text { para turistas }\end{array}$ & $\begin{array}{l}\text { Número de produtos respeitando } \\
\text { padrões; } \\
\text { Número de turistas adotando } \\
\text { padrões recomendados }\end{array}$ \\
\hline
\end{tabular}


Tabela 8: Objetivos, medidas/instrumentos e indicadores para o planejamento de transportes para a sociedade. Adaptado de Kölbl, Niegl e Knoflacher (2008)

\begin{tabular}{|c|c|c|}
\hline Objetivos & Medidas/ instrumentos & Indicadores \\
\hline $\begin{array}{l}\text { Aumentar usabilidade e } \\
\text { acessibilidade }\end{array}$ & $\begin{array}{l}\text { Uso igual e livre do espaço } \\
\text { público; } \\
\text { Priorização de estruturas de } \\
\text { mobilidade não-motorizada }\end{array}$ & $\begin{array}{l}\text { Tempo de viagem e frequência de } \\
\text { diferentes grupos sociais; } \\
\text { Mortes por área e ano }\end{array}$ \\
\hline Aumentar saúde e bem estar & $\begin{array}{l}\text { Reduzir poluição do tráfego; } \\
\text { Criar estruturas para veículos não } \\
\text { motorizados; } \\
\text { Criar áreas verdes }\end{array}$ & $\begin{array}{l}\text { Estatísticas de saúde da } \\
\text { população em relação à poluição; } \\
\text { Níveis de poluição de gases e } \\
\text { partículas; } \\
\text { Temperatura da rua; } \\
\text { Nível de umidade }\end{array}$ \\
\hline $\begin{array}{l}\text { Assegurar satisfação das } \\
\text { necessidades humanas }\end{array}$ & $\begin{array}{l}\text { Criar mix e diversidade entre áreas } \\
\text { de shopping, lazer, verdes, } \\
\text { educacionais, etc.; } \\
\text { Uso eficiente e igual do espaço } \\
\text { público }\end{array}$ & $\begin{array}{l}\text { Participação dos modais na matriz } \\
\text { de transportes; } \\
\text { Densidade de população, } \\
\text { trabalhos, lojas, escolas; } \\
\text { Distância para ciclovias, paradas } \\
\text { de transporte público e } \\
\text { estacionamentos; } \\
\text { Níveis de crime }\end{array}$ \\
\hline padrões de & $\begin{array}{l}\text { Reduzir velocidade do tráfego; } \\
\text { Reduzir volume de tráfego; } \\
\text { Aumentar educação no trânsito; } \\
\text { Policiamento }\end{array}$ & $\begin{array}{l}\text { Número de mortes e acidentes por } \\
\text { ano; } \\
\text { Locais e tipos dos acidentes em } \\
\text { relação à velocidade e volume de } \\
\text { tráfego }\end{array}$ \\
\hline $\begin{array}{l}\text { Sustentar e desenvolver } \\
\text { oportunidades de trabalho e } \\
\text { serviços próximas às áreas } \\
\text { residenciais }\end{array}$ & $\begin{array}{l}\text { Investimentos que atendam à } \\
\text { economia local; } \\
\text { Desenvolvimento de economias } \\
\text { locais com responsabilidades } \\
\text { locais }\end{array}$ & $\begin{array}{l}\text { Número de empregos ou } \\
\text { empresas por região; } \\
\text { Número e distância de viagens } \\
\text { entre regiões próximas, em função } \\
\text { do modal; } \\
\text { Montante de investimento local }\end{array}$ \\
\hline $\begin{array}{l}\text { Sustentar e } \quad \begin{array}{c}\text { desenvolver } \\
\text { oportunidades } \\
\text { educacionais }\end{array} \\
\text { próximas às áreas residenciais }\end{array}$ & $\begin{array}{l}\text { Desenvolvimento de escolas e } \\
\text { centros educacionais locais; } \\
\text { Desenvolver e intensificar } \\
\text { infraestrutura não motorizada }\end{array}$ & $\begin{array}{l}\text { Participação dos modais e } \\
\text { distância das viagens para escolas } \\
\text { e centros educacionais; } \\
\text { Comprimento da rede não } \\
\text { motorizada }\end{array}$ \\
\hline $\begin{array}{l}\text { Sustentar e desenvolver áreas } \\
\text { verdes e de lazer próximas às } \\
\text { áreas residenciais }\end{array}$ & $\begin{array}{l}\text { Desenvolver áreas proibidas para } \\
\text { veículos e áreas verdes próximas } \\
\text { às áreas residenciais; } \\
\text { Desenvolver acessos livres para } \\
\text { transporte não motorizado }\end{array}$ & $\begin{array}{l}\text { Participação dos modais e } \\
\text { distâncias das viagens de lazer; } \\
\text { Distância para parques e áreas } \\
\text { verdes }\end{array}$ \\
\hline
\end{tabular}

As tabelas acima (adaptadas de Kölbl, Niegl e Knoflacher (2008)) apresentam um exemplo de relação de objetivos, medidas e indicadores, dentre tantas opções possíveis. Esta parece ser focada em regiões urbanas e condicionadas por uma excessiva preocupação com aspectos ambientais, que pode não ser (e provavelmente não será), a preocupação primeira no caso a ser avaliado nessa dissertação. 


\subsubsection{Decisão com problemas de múltiplos critérios}

O processo de tomada de decisão envolve, quase sempre, a escolha da melhor opção considerando múltiplos critérios, fatores ou objetivos. Depende da avaliação específica das alternativas propostas, resultando na seleção daquele que melhor atenda a um conjunto de critérios (Saaty, 1980). É difícil, nesses casos, existir uma solução objetiva que seja melhor que outra para todos os critérios considerados simultaneamente.

Essa dificuldade exige a determinação de um nível de conciliação dos múltiplos objetivos. As técnicas ou algoritmos conhecidos como programação matemática (tais como programação linear, programação não-linear e a programação dinâmica) não são adequadas para resolver este tipo de problema, pois necessitam de funções bem definidas para representar os múltiplos objetivos, além de não incorporarem objetivos que envolvam valores qualitativos ou imprecisos (Shimizu, 2006).

Para resolver problemas de decisão de multicritério, nos quais o tomador de decisão deve fazer uma escolha entre várias alternativas, Thomas L. Saaty, em 1970, desenvolveu uma técnica baseada em análise hierárquica. $O$ método tem como objetivo simular a maneira como as pessoas pensam.

Nogueira (2002) afirma que a maioria dos problemas complexos envolvendo múltiplos critérios, inclusive com objetivos conflitantes, pode ser estruturada hierarquicamente pelo Analytic Hierarchy Process (AHP), sem restrições. Este é um processo flexível, que permite incluir e medir fatores importantes, qualitativos e quantitativos. No AHP, por exemplo, podem ser integradas questões geralmente conflitantes - como econômica, social e ambiental - para a implantação de obras de infraestrutura.

O método de análise hierárquica é um sistema para análise e síntese de problemas complexos que permite justificar as decisões e avaliações complicadas, tornando possível examinar os elementos ou partes de um problema de forma isolada (Forman \& Selly, 2001). Cada elemento é comparado com outro, sempre segundo um dos critérios. O processo de decisão em análise é simplificado, pois as comparações são feitas aos pares. 
Este método tem sido empregado em diversas situações, entre elas, definição de prioridades, avaliação de custos e benefícios, alocação de recursos, mensuração de desempenho (benchmarking), avaliação ou pesquisa de mercado, determinação de requisitos, decisões estratégicas. Na visão de Morita (1998), o método tem se difundido devido à simplicidade na aplicação, naturalidade no trato de aspectos subjetivos e a flexibilidade de uso.

Através da comparação por pares, o método mostra-se capaz de capturar a importância relativa entre estes fatores de maneira confiável, mesmo que os critérios sejam avaliados apenas qualitativamente. É importante ressaltar que apesar da potencialidade do método na captura da importância relativa entre os diversos fatores, a subjetividade presente na avaliação dos critérios pode ocasionar um resultado com alguma imprecisão.

Após a definição do problema, objetivo, alternativas de solução e critérios de avaliação das soluções, a aplicação do método AHP pode ser dividida em quatro partes (Colin, 2007):

1. Representação da hierarquia: desenvolvimento da hierarquia de decisão associadas aos vários níveis de elementos inter-relacionados (Figura 5) [onde o primeiro nível é composto pelo objetivo];

2. Comparação dos pares: avaliação de preferências com relação a cada elemento de decisão em um dado nível de hierarquia;

3. Método do autovalor: uso do método do autovalor para estimar os pesos relativos dos elementos de decisão em um dado nível e avaliar a consistência das preferências estabelecidas nas comparações de pares;

4. Agregação de prioridades: agregação das prioridades relativas de modo a avaliar o resultado referente ao objetivo. 
Nível 1

Objetivo

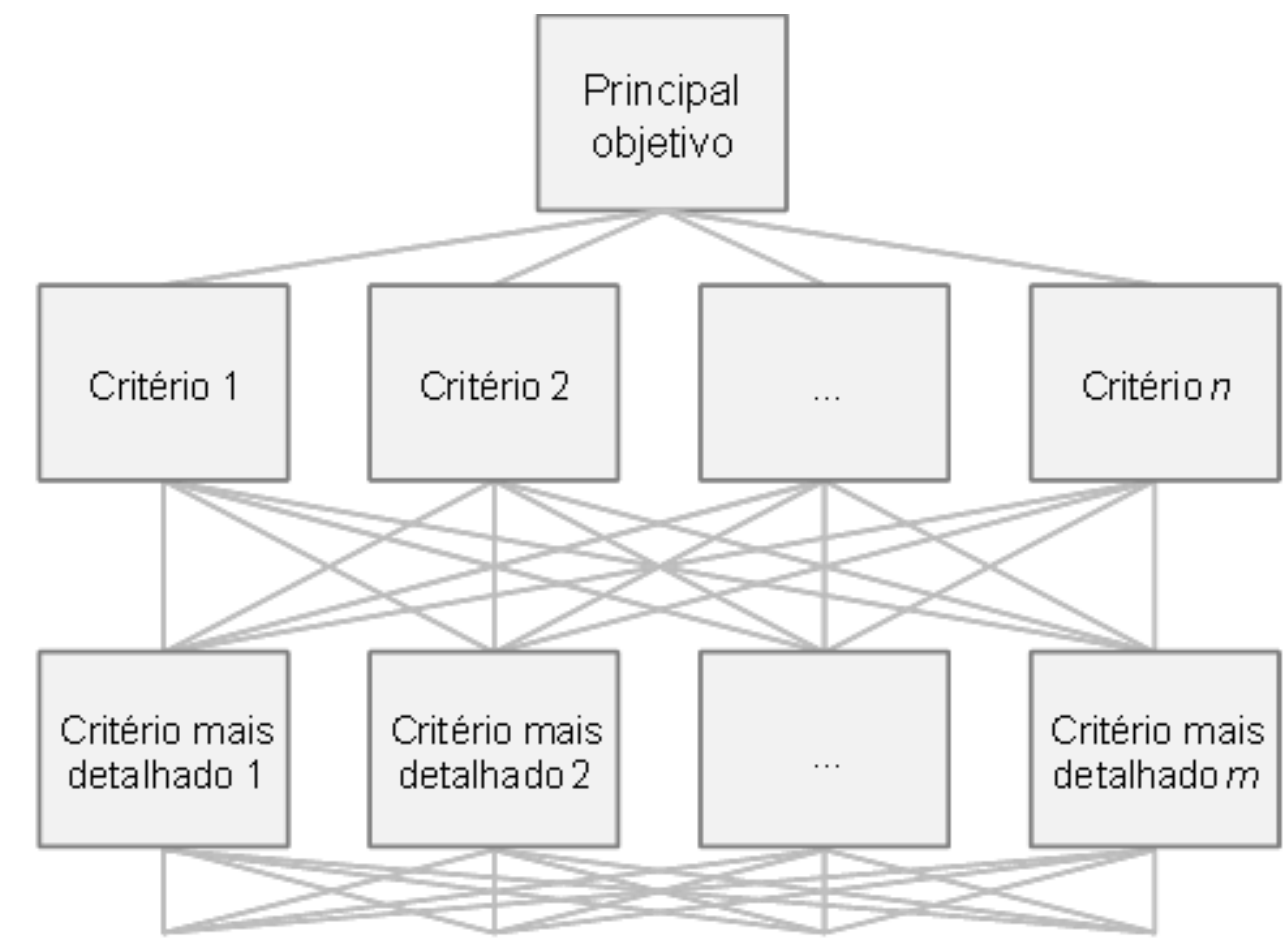

Nível 3

Critérios de decisẫo

Nível 2

Critérios de decisẫo

Nível $K$

Alternativas de decisẫo

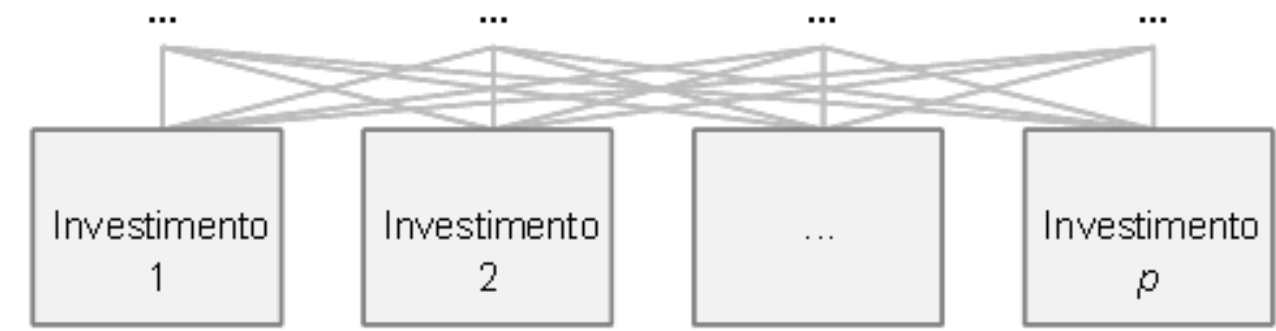

Figura 5: Esquema de decisão hierárquico genérico. Adaptado de Colin (2007)

O AHP usa uma escala de comparação - escala Saaty - que julga os critérios com números absolutos de 1 a 9. 
Tabela 9: Escala de Razão. Fonte: Saaty (1991)

\begin{tabular}{|c|c|c|}
\hline $\begin{array}{l}\text { Intensidade de } \\
\text { Importância }\end{array}$ & Definição & Explicação \\
\hline 1 & Mesma importância & $\begin{array}{l}\text { As duas atividades contribuem igualmente } \\
\text { para o objetivo }\end{array}$ \\
\hline 3 & $\begin{array}{l}\text { Importância pequena de uma } \\
\text { sobre a outra }\end{array}$ & $\begin{array}{l}\text { A experiência e o julgamento favorecem } \\
\text { levemente uma atividade em relação a } \\
\text { outra }\end{array}$ \\
\hline 5 & Importância grande ou essencial & $\begin{array}{l}\text { A experiência e o julgamento favorecem } \\
\text { fortemente uma atividade em relação a } \\
\text { outra }\end{array}$ \\
\hline 7 & $\begin{array}{l}\text { Importância } \quad \text { grande } \\
\text { demonstrada }\end{array}$ & $\begin{array}{l}\text { Uma atividade é muito fortemente } \\
\text { favorecida em relação a outra; sua } \\
\text { dominação de importância é demonstrada } \\
\text { na prática }\end{array}$ \\
\hline 9 & Importância absoluta & $\begin{array}{l}\text { A evidencia favorece uma atividade em } \\
\text { relação a outra com o mais alto grau de } \\
\text { certeza }\end{array}$ \\
\hline $2,4,6,8$ & $\begin{array}{l}\text { Valores intermediários ou valores } \\
\text { adjacentes }\end{array}$ & $\begin{array}{l}\text { Quando se procura uma condição entre } \\
\text { duas definições }\end{array}$ \\
\hline
\end{tabular}

A comparação de pares é realizada com base na escala da Tabela 9, calculando posteriormente o autovalor e autovetor da matriz.

Suponha o exemplo (retirado de Colin, 2007) de uma empresa que queira criar valor e para isso usa 3 critérios de decisão: crescimento, lucratividade e perenidade. Segundo o avaliador, lucratividade possui importância de pequena a grande sobre crescimento, determinando o valor 4 para o elemento lucratividade-crescimento. Da mesma forma, perenidade é de fortemente favorecida a muito fortemente favorecida em relação à lucratividade, recebendo o valor 6 . O mesmo raciocínio vale para perenidade em relação à lucratividade que está na faixa de igualmente preferível a levemente preferível, com valor 2.

A diagonal principal compara os critérios com eles mesmos e, portanto, possuem a mesma importância, sendo 10 valor de todos os elementos. Os elementos simétricos em relação a diagonal principal apresentam valores inversos, no exemplo, como lucratividade é quatro vezes preferível a crescimento, é razoável supor que crescimento seja $1 \frac{1}{4}$ preferível a lucratividade.

Dessa forma, todos os elementos da matriz de comparação ficam determinados (Tabela 10). 
Tabela 10: Comparação entre os pares de critérios. Fonte: Colin (2007)

\begin{tabular}{|c|c|c|c|}
\hline Critério & Crescimento & Lucratividade & Perenidade \\
\hline Crescimento & 1 & $1 / 4$ & $1 / 6$ \\
\hline Lucratividade & 4 & 1 & $1 / 2$ \\
\hline Perenidade & 6 & 2 & 1 \\
\hline
\end{tabular}

O próximo passo é o cálculo do autovetor, que consiste na representação dos critérios de decisão normalizados. O AHP é capaz de lidar e absorver julgamentos inconsistentes (Morita, 1998). A consistência é um critério importante, o qual requer uma avaliação cuidadosa para validar a realidade.

Morita (1998) afirma que o índice de consistência de uma matriz de comparação paritária é usado para mostrar quanto o valor de $\lambda$ máx (maior autovetor da matriz de comparação) desta matriz está afastado do valor esperado. O valor teórico esperado de $\lambda$ máx é $n$, onde $n$ representa o número de fatores de decisão e, portanto seu desvio é dado por $(\lambda \operatorname{máx}-n)$. Esta diferença é medida relativamente ao número de graus de liberdade desta matriz $(n-1)$. Essa propriedade permite o uso de um índice de consistência representado por IC e calculado como:

$$
\text { IC }=\frac{\lambda \text { máx }-n}{n-1}
$$

E do quociente de consistência QC, que é calculado como:

$$
Q C=\frac{I C}{I C A}
$$

Onde ICA é o índice de consistência aleatório, sendo obtido através das comparações aos pares de forma aleatória. Como regra geral, $Q C \leq 0,1$ é considerado um valor aceitável. Se $\mathrm{QC}>0,1$ recomenda-se que o analista reavalie suas comparações de pares, pois estão inconsistentes (Colin, 2007).

Para matrizes de ordem $n$, os ICAs em função da ordem da matriz de comparação são definidos de acordo com a Tabela 11.

Tabela 11: ICAs em função da ordem da matriz. Fonte: Colin (2007)

\begin{tabular}{|c|c|c|c|c|c|c|c|c|c|c|}
\hline$n$ & 1 & 2 & 3 & 4 & 5 & 6 & 7 & 8 & 9 & 10 \\
\hline ICA & 0 & 0 & 0,52 & 0,89 & 1,11 & 1,25 & 1,35 & 1,40 & 1,45 & 1,49 \\
\hline
\end{tabular}


Com o intuito de priorizar as alternativas de decisão na busca do principal objetivo do problema, a quarta parte da metodologia agrega as prioridades relativas dos vários níveis obtidos no cálculo dos autovetores.

Esse passo consiste em criar outras matrizes de comparação para cada uma das alternativas de decisão no nível $i+1$ com relação aos critérios do nível $i$. O tomador de decisão, então, agregará as prioridades resultantes com as prioridades encontradas no nível $i$ de modo a obter a melhor decisão para o objetivo do problema.

O rápido crescimento da quantidade de comparações paritárias necessárias com o aumento do tamanho da matriz é uma das dificuldades apontadas no AHP. O efeito da reversão de ordem de prioridade que ocorre com a alteração das alternativas dominantes em função da inclusão ou exclusão de alternativas irrelevantes é outro problema apontado pelos críticos do AHP. A reversão de ordem é atribuída pelos pesquisadores como o "efeito colateral" do cálculo que normaliza o vetor de prioridades.

Diante do exposto no item 2.1 e com o detalhamento da metodologia do AHP, a aplicação do método para priorização de objetivos e investimentos em infraestrutura de transporte mostra-se adequada, pois, serão analisadas diversas alternativas de obras sob diversos critérios de diferentes naturezas - ambientais, econômicas e sociais. 


\subsection{Planos de transporte desenvolvidos no Brasil}

\subsubsection{Eventos históricos}

O Brasil historicamente privilegiou o desenvolvimento do modal rodoviário, mas, apesar disso, também apresentou momentos de atenção às ferrovias. Essa preferência é resultado de uma conjugação de fatores que aconteceram no país desde a época imperial com a abertura da primeira estrada de rodagem.

A Tabela 12 relaciona cronologicamente os principais acontecimentos globais da política nacional com os planos de transportes desenvolvidos. 
Tabela 12: Planos desenvolvidos no Brasil entre 1940 e 2000. Fonte: Andrade, et al (2006)

\begin{tabular}{|c|c|}
\hline \multicolumn{2}{|c|}{ Planejamentos no Brasil } \\
\hline Globais & Transportes \\
\hline $\begin{array}{l}1942 \text { - Plano Quinquenal de Obras de } \\
\text { Reaparelhamento da Defesa Nacional }\end{array}$ & \\
\hline 1943 - Plano de Obras e Equipamentos & 1944 - Planos Rodoviários \\
\hline 1946-1947 - Plano Salte (49/53) & \\
\hline 1951 - Plano Global (51/53) & $\begin{array}{l}1951 \text { - Plano Nacional de Viação Fluvial e Plano } \\
\text { Nacional de Viação }\end{array}$ \\
\hline 1956-1960 - Plano de Metas & 1956 - Plano Rodoviário e Ferroviário \\
\hline 1958-1959 - Plano de Estabilização & \\
\hline $\begin{array}{l}1963 \text { - Plano Trienal de Desenvolvimento } \\
\text { Econômico }(1963 / 65)\end{array}$ & \\
\hline $\begin{array}{l}\text { 1964 - Plano de Ação Econômica do Governo } \\
(1964 / 67)\end{array}$ & $\begin{array}{l}1964 \text { - Plano Nacional de Viação e } \\
\text { Plano de Expansão Ferroviária }\end{array}$ \\
\hline $\begin{array}{l}1968 \text { - Programa Estratégico de } \\
\text { Desenvolvimento (1968/1969) }\end{array}$ & 1967 - Plano Rodoviário Nacional \\
\hline $\begin{array}{l}1969 \text { - Plano de Metas e Bases para a Ação do } \\
\text { Governo (1969/1973) }\end{array}$ & \\
\hline $\begin{array}{l}1970 \text { - Plano Nacional de Desenvolvimento e } \\
\text { Segurança (1970/1973) }\end{array}$ & \\
\hline $\begin{array}{l}1971 \text { - I Plano Nacional de Desenvolvimento } \\
\text { Econômico }(1971 / 74)\end{array}$ & \\
\hline $\begin{array}{l}\text { 1971-1974 - II Plano Nacional de } \\
\text { Desenvolvimento Social e Econômico }\end{array}$ & $\begin{array}{l}1973 \text { - Plano Nacional de Viação (cria o Sistema } \\
\text { De Transportes) } \\
1973 \text { - Programa de Desenvolvimento } \\
\text { Ferroviário }\end{array}$ \\
\hline $\begin{array}{l}\text { 1979-1985 - III Plano Nacional de } \\
\text { Desenvolvimento Social e Econômico, Plano } \\
\text { Nacional de Desburocratização e Programa de } \\
\text { Energia }\end{array}$ & $\begin{array}{l}1975 \text { - Programa de Desenvolvimento } \\
\text { Ferroviário e Programa de Construção Naval } \\
1978 \text { - Programa Nacional de Transportes }\end{array}$ \\
\hline 1985 -1990 - Recuperação da Imagem Nacional & \\
\hline $\begin{array}{l}1990 \text { - Programa Federal de } \\
\text { Desregulamentação da Economia e Programa } \\
\text { Nacional de Desestatização }\end{array}$ & 1993 - Lei de Modernização dos Portos \\
\hline $\begin{array}{l}1996 \text { - Plano Plurianual (1996/99) - Brasil em } \\
\text { Ação }\end{array}$ & 1995 - Lei das Concessões \\
\hline $\begin{array}{l}2000 \text { - Plano Plurianual (2000/2003) - Avança } \\
\text { Brasil }\end{array}$ & \\
\hline
\end{tabular}


Com o intuito de conhecer o desenvolvimento rodoviário e ferroviário - baseado em Transportes no Brasil: Histórias e reflexões (GEIPOT, 2001) - fez-se um levantamento dos principais empreendimentos desde a descoberta do Brasil para esses modais.

\section{Rodoviário}

Período Imperial (1822 - 1889): A primeira estrada de Rodagem (Estrada União Indústria entre Petrópolis e Juiz de fora) com 144 km de extensão.

República Velha (1893-1930): Governar é abrir estradas - slogan de Washington Luís presidente brasileiro na época:

- 1919: A empresa americana Ford recebe autorização para instalar uma montadora de veículos no país, diminuindo assim os custos aduaneiros para comercialização de automóveis;

- 1925: É concedida a General Motors autorização para a montagem de veículos no país;

- 1926: Washington Luís torna-se presidente do Brasil e a construção rodoviária passa a ser a diretriz básica do governo federal;

- 1928: Iniciam-se as construções das rodovias Rio de Janeiro - Petrópolis e Rio de Janeiro - São Paulo com recursos federais e estaduais.

Nesse período, o Brasil já contava com aproximadamente $59 \mathrm{~km}$ de vias asfaltadas, $36 \mathrm{~km}$ concretadas e outros 1.550 pavimentados com macadame ${ }^{5}$.

Era Vargas (1930-1945): Lançado o primeiro Plano rodoviário nacional:

- 1937: Criação do Departamento Nacional de Estradas de Rodagem, que instituía um órgão central que seria uma importante ferramenta no desenvolvimento rodoviário no Brasil (Lei no․ 467 de 31 de julho);

- 1944: Primeiro plano rodoviário nacional é criado, constituído por 6 rodovias longitudinais, 15 transversais e 6 ligações totalizando 35.574 km;

\footnotetext{
${ }^{5}$ Macadame é um sistema de pavimentação de estradas e ruas por meio de brita e saibro que se recalca com um cilindro. Origem da palavra: De J. Mac Adam, engenheiro escocês, 1756-1836.
} 


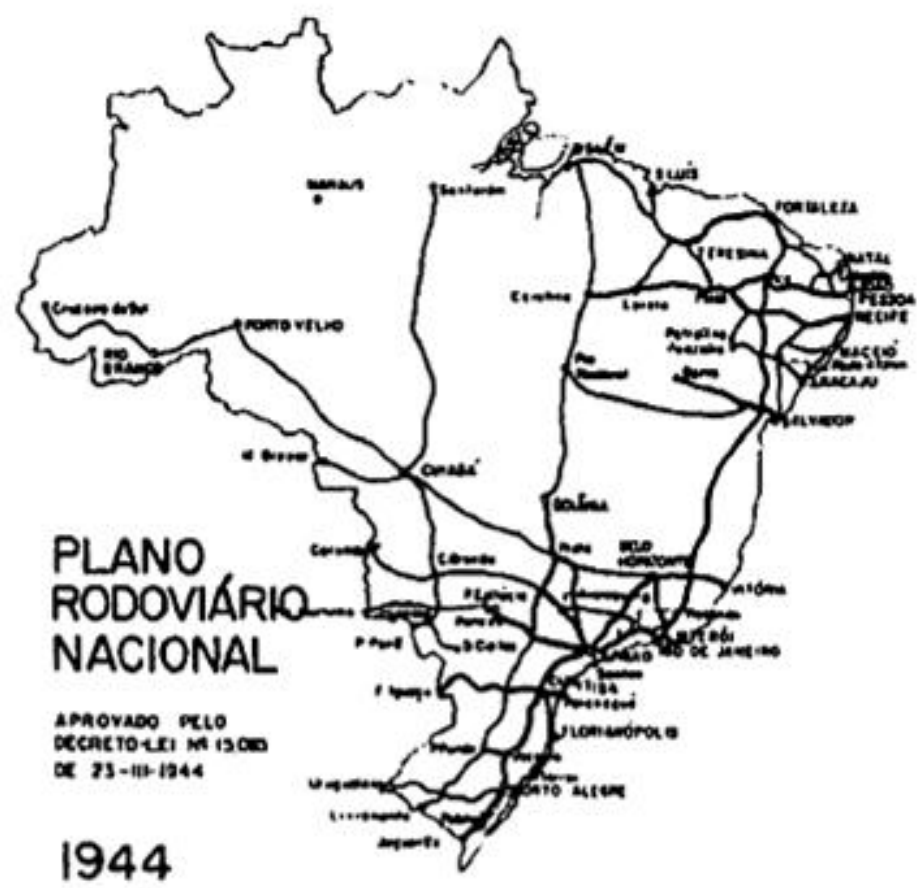

Figura 6: Plano Rodoviário Nacional de 1944. Fonte: GEIPOT (2001)

Apesar do intenso desenvolvimento, até 1945 apenas $420 \mathrm{~km}$ de rodovias eram pavimentadas.

Pós-Guerra (1945-1964): Construção de Brasília - A consolidação do domínio do sistema rodoviário;

Nesse período, a malha pavimentada atingiu 25.000 km, um CAGR ${ }^{6}$ de $25 \%$ de 1955 a 1965.

Regime Militar (1964-1985): Plano Nacional de Viação - interligação da capital federal com outras regiões e com portos estratégicos.

De 1965 a 1985 a malha pavimentada atingiu aproximadamente $116.500 \mathrm{~km}$ de extensão, perfazendo um crescimento médio de $8 \%$ a.a. (CAGR). Apesar do

${ }^{6}$ Compound Annual Growth Rate (Taxa media de crescimento anual).

$C A G R=\left(\left(\frac{\text { Valor final }}{\text { Valor inicial }}\right)^{\left(\frac{1}{\text { número de anos }}\right)}\right)-1$ 
expressivo crescimento acumulado, a partir da década de 80 o ritmo de diminuiu drasticamente, anotando CAGR de $1 \%$ de 75 a 80 e $5 \%$ de 80 a 85 .

É no final do regime militar que se inicia um longo período sem investimentos públicos em infraestrutura de transportes que irá culminar na dramática situação atual.

\section{Ferroviário:}

Com o advento da Revolução Industrial, o mundo conheceu o motor a vapor e as ferrovias. No Brasil não foi diferente, tendo estes avanços tecnológicos sido implementados poucos anos após sua invenção nos países europeus.

O desenvolvimento ferroviário brasileiro, como cita a Associação Nacional de Transportadores Ferroviários (ANTF), "sempre esteve intimamente ligado a políticas de governo, que, por seu turno, variaram grandemente ao longo da história”. À luz da sistematização dessa relação, a ANTF dividiu a evolução do sistema ferroviário segundo fases cronológicas, correlacionadas a fases da história nacional, quais sejam:

Período Imperial (1835 - 1889): Início da implantação de ferrovias no Brasil e expansão acelerada - primeira ferrovia construída por Barão de Mauá:

- 1858: Instalação da primeira empresa inglesa no país com a Recife and São Francisco Railway Company, entre Recife e Cabo, em Pernambuco. Conclusão do primeiro segmento, entre o Rio de Janeiro e Queimados, na Baixada Fluminense, daquela que seria por muitos anos a mais importante ferrovia do Brasil: a Estrada de Ferro Dom Pedro II (E. F. Dom Pedro II), mais tarde E. F. Central do Brasil.

Visando acelerar o transporte de cargas entre o interior e os portos houve um aumento de $25,5 \%$ a.a. (CAGR de 1835 a 1873) na malha ferroviária nacional, atingindo em 1873, aproximadamente, $1.100 \mathrm{~km}$ de extensão ${ }^{7}$. De 1873 a 1889 o

\footnotetext{
${ }^{7}$ Fonte: IBGE
} 
crescimento foi de $14,3 \%$ a.a., resultando numa malha de aproximadamente 10.000 $\mathrm{km}$.

República Velha (1889 - 1930): O estado assume o controle de várias empresas em dificuldades financeiras:

- 1890: Início do resgate de ferrovias privadas pelo governo brasileiro, com a encampação da E. F. São Paulo e Rio de Janeiro, posteriormente incorporada à E. F. Central do Brasil.

Ainda com crescimento acelerado, a malha ferroviária brasileira mais que triplicou nesta fase do desenvolvimento, embora muitas ferrovias tenham sido incorporadas pelo Estado devido a dificuldades financeiras. Houve também avanço na administração política das ferrovias, com a criação de órgãos reguladores. A malha atingiu aproximadamente $32.500 \mathrm{~km}$ em 1930.

Era Vargas e Pós-Guerra (1930 - 1960): Amplo controle estatal das empresas antes privadas e diminuição do ritmo de crescimento:

- 1942: Criação da Cia. Vale do Rio Doce, que absorveu E. F. Vitória a Minas, que se tornaria em pouco tempo a mais importante ferrovia do país.

Neste período, percebe-se um grande controle por parte do governo das ferrovias nacionais. Para o controle mais eficiente destas, foi criada a Rede Ferroviária Federal S.A. (RFFSA), que existiria até a nova privatização das vias. É notável também uma redução na velocidade de crescimento da malha nacional, com CAGR de apenas $0,5 \%$ a.a.

Regime Militar (1960 - 1990): Consolidação da malha em poucas empresas públicas, erradicação de ramais antieconômicos e implantação de projetos seletivos de caráter estratégico.

Com vias antieconômicas sendo erradicas e sendo permitida somente a criação de vias de caráter estratégico, foi o período histórico em que houve o maior controle da malha férrea nacional. No período a malha diminuiu de aproximadamente $37.500 \mathrm{~km}$ para $30.000 \mathrm{~km}$.

Atual (1990 - atual): Privatização de todo o sistema ferroviário nacional: 
- 1996: Privatizadas as malhas centro-leste, sudeste e oeste da RFFSA, sendo as novas concessionárias a Ferrovia Centro - Atlântica (FCA), MRS Logística e Ferrovia Novoeste, respectivamente;

- 1997: Privatizadas as malhas sul e Tereza Cristina da RFFSA, sendo as novas concessionárias a Ferrovia Sul - Atlântica - atualmente América Latina Logística (ALL) - e Ferrovia Teresa Cristina (FTC), respectivamente.

\subsubsection{Planejamento recente}

No final dos anos 60, o americano Daniel Keith Ludwig tinha refinarias de petróleo na Escócia e Panamá, minas de sal no México, de carvão na Austrália e minérios no Canadá. Era também o maior operador de navios do mundo, à frente do lendário Aristóteles Onassis. Em 1967, resolveu-se por montar um complexo de produção de papel, madeira e alimentos numa área quase do tamanho de estado de Sergipe, localizada na fronteira do Pará com Amapá. Como parte do projeto Jari Forest Products, Ludwig construiu estradas, aeroportos e uma ferrovia e trouxe do Japão uma fábrica de celulose sobre uma plataforma flutuante. Anos depois, com a falência do projeto, perdeu 1,5 bilhão de dólares e saiu do Brasil. Afirmou na época que empreender em um país sem planejamento e infraestrutura é uma atividade arriscada demais (Adaptado do Anuário EXAME de infraestrutura 2010 - É assim o Brasil Real - dezembro de 2010).

O planejamento estratégico logístico na história recente do Brasil tem acontecido aos soluços. Planos ousados têm se alternado com longos períodos de desinteresse governamental.

A constituição do Grupo Executivo de Integração da Política de Transportes (GEIPOT) representou uma iniciativa promissora. O órgão criado em 1965 com direção superior formada pelo Ministro da Viação e Obras Públicas, Ministro de Estado da Fazenda, Ministro Extraordinário para o Planejamento e Coordenação Econômica e pelo Chefe do Estado Maior das Forças Armadas, funcionava como uma central de inteligência logística multiministerial, prestando "apoio técnico e 
administrativo aos órgãos do Poder Executivo que tenham [tivessem] atribuições de formular, orientar, coordenar e executar a política nacional de transportes nos seus diversos modais, bem como promover, executar e coordenar atividades de estudos e pesquisas necessários ao planejamento de transportes no País"”.

Os trabalhos do GEIPOT Ihe permitiram a constituição de um corpo técnico qualificado, com visão global do processo decisório do Estado, e um valioso acervo de informações e conhecimentos, transformando-o em centro de referência para os estudos de transportes no Brasil. A disponibilidade de informação para todos os agentes do desenvolvimento, incluindo a iniciativa privada, é certamente o aspecto isolado que oferece maior eficiência e eficácia na concepção e implantação de projetos de infraestrutura. Esse papel era, de uma forma ou de outra, cumprido pelo GEIPOT.

Em 2001 o setor de transportes no Brasil passou por uma reestruturação, e foram criados, com auxílio do GEIPOT, o Conselho Nacional de Integração de Política de Transportes Terrestres $(\mathrm{CONIT})^{9}$ - que pelas atribuições deveria ser o substituto direto do GEIPOT-, a Agência Nacional de Transportes Aquaviários (ANTAQ), a Agência Nacional de Transportes Terrestres (ANTT) e o Departamento Nacional de Infraestrutura de Transportes (DNIT) ${ }^{10}$.

Sem entrar no mérito da eficácia das ações do GEIPOT, o fato é que com a instalação desses, o órgão deixou de atuar em 2002 e foi extinto legalmente por Medida Provisória em maio de 2008, deixando o planejamento logístico intermodal sob um longo período de dormência.

Portanto, a área de transportes ficou sem uma estrutura de planejamento, especialmente de longo prazo desde o início do Governo Lula. O acervo de informações consolidadas - anuários estatísticos de transporte, indicadores

\footnotetext{
${ }^{8}$ GEIPOT: http://www.geipot.gov.br/.

${ }^{9}$ O CONIT é um órgão vinculado à Presidência da República, criado em 2001, cuja principal atribuição é assessorar o Presidente da República, propondo políticas nacionais de integração dos diferentes modais de transporte (conforme detalhado no anexo 7.1).

${ }^{10}$ Todos esses órgãos e agências possuem suas atribuições detalhadas no anexo 7.1.
} 
internacionais de densidade de transporte, investimentos realizados e previstos, entre outros - e atualizadas periodicamente, tão vasto com o GEIPOT, não existe mais, resultando na ausência de instrumentos governamentais que avaliem as condições dos transportes e de sua infraestrutura, tanto a nível municipal, quanto federal.

“Hoje, qualquer conjunto de perguntas estratégicas que se queira fazer sobre a logística de carga e passageiros, não se sabe a quem fazê-lo, pelo simples motivo de que não há, em qualquer órgão do governo, quem detenha essa informação ou mesmo os dados sistematizados que poderiam gerá-la." (José Augusto Valente, exsecretário da Secretaria de Política Nacional de Transportes (SPNT), em "Empresas e autarquias estratégicas no setor de transportes: GEIPOT" - Agência T1 - 03 de dezembro de 2010).

Dos presidentes de 300 das maiores empresas do Brasil entrevistados pela Revista Exame $^{11}, 55 \%$ citaram que a gestão pública mais eficiente é o ponto fundamental para resolver as principais deficiências de infraestrutura. Do mesmo grupo, 53\% também apontaram que a política de longo prazo e definição de prioridades é fundamental, seguidos de marcos regulatórios que deem segurança ao investidor (26\%), menos burocracia nos licenciamentos ambientais (18\%) e maior participação da iniciativa privada (18\%). Tais dados reforçam a percepção de que falta um órgão responsável por essa gestão eficiente e que realize o planejamento estratégico de longo prazo.

Segundo Valente (2010), o órgão que tenta cumprir, em parte, essa função é a SPNT. Essa secretaria, apesar de ter coordenado a elaboração do Plano Nacional de Logística e Transportes (PNLT) - que pretendia ser um documento de planejamento estratégico - não tem equipe e nem recursos suficientes para responder a essa demanda, não possuindo condições para um trabalho permanente. Valente (2010) defende, adicionalmente ao planejamento estratégico, a criação da Empresa Brasileira de Pesquisas em Transportes (EBPT), nos moldes da Empresa

\footnotetext{
${ }^{11}$ Fonte: Anuário EXAME de infraestrutura 2010 - É assim o Brasil Real - dezembro de 2010.
} 
de Pesquisas Energéticas (EPE), pois considera inviável qualquer processo de planejamento, sem uma estrutura que gerasse, guardasse, atualizasse, pesquisasse, processasse informações estratégicas, bem como monitorasse a logística de cargas e de passageiros.

O PNLT, lançado em $2007^{12}$, foi o primeiro esforço para a retomada do planejamento estratégico. O governo esperava se instrumentar para superar os entraves do setor, aliando planejamento e recursos para a execução. Mas isso não está de fato ocorrendo, já que falta um órgão centralizador.

O contexto da criação e as pretensões do PNLT ficam claros nas palavras do então Ministro dos Transportes, Paulo Sérgio Passos (PNLT, 2007):

Ao assumir o posto de Secretário-Executivo e, posteriormente, o de Ministro dos Transportes, em abril de 2006 (retornando ao cargo de Secretário-Executivo em 2007 e reassumindo o Ministério dos Transportes em março de 2010), decidi enfrentar essa distorção (progressivo processo de esvaziamento do planejamento de transportes a partir da década de 1990) e, numa feliz combinação de circunstâncias, tive condições de articular os meios necessários à retomada do processo de planejamento de transportes de longo prazo no Brasil [...]

Algumas premissas básicas nortearam este trabalho [...] implementar um método de planejamento científico, baseado em sistema de dados georreferenciados, ancorado em análise macroeconômica compreensiva e consistente, desenvolvida pela Universidade de São Paulo, e utilizando modelos adequados de simulação e projeção de transportes. [...]

O PNLT aponta recomendações de caráter institucional e identifica um portfólio de projetos prioritários e estruturantes, que remete ao futuro desenvolvimento econômico que se deseja para nosso País.

\footnotetext{
${ }^{12}$ Os relatórios são datados de 2007, mas apenas em 2008 o relatório executivo foi divulgado pelo Ministério dos Transportes (MnT). O restante dos relatórios, com algum detalhamento dos procedimentos adotados foi disponibilizado em 2009/2010 (http://www.transportes.gov.br/ - acessado em 12/08/2010).
} 
É um estudo que não se pretende venha a ficar estagnado no tempo, pois apresenta as condições necessárias para receber atualizações periódicas no arcabouço macroeconômico que o sustenta, bem como revisões em seu elenco de ações e de empreendimentos. Mais que um plano, o que se oferece agora à sociedade é um processo de planejamento permanente.

Que o PNLT sirva como instrumento orientador na formulação de políticas públicas do setor, contribua para maior racionalidade e qualificação do gasto público, e represente sólido subsídio para os próximos PPAs [Planos Plurianuais].

O PNLT elenca como principais objetivos a retomada do processo de planejamento no setor de transportes, envolvendo todas as modalidades de transporte, 0 levantamento dos custos incorridos na cadeia logística entre os locos de origem e destino das cargas, e a orientação do melhor equilíbrio da matriz de transportes do país.

No entanto, apesar da extensão do trabalho realizado, o planejamento estratégico em si, na forma que se deve segundo esse autor, não foi elaborado, pois não se fez a avaliação de mérito com critérios claros para a priorização dos investimentos. Isso pode ter sido proposital de forma a permitir soluções de conveniência política, mas, ainda assim, deveriam figurar dentro de um grupo de obras já analisadas.

Reforçando essa tese, o dirigente da Companhia Docas do Espírito Santo (Codesa), Sr. Angelo José de Carvalho Baptista, define o PNLT como "um conjunto de projetos que não elenca as prioridades e não define cronograma seguro". Ele não pode ser considerado o planejamento estratégico final para o setor de transportes como um todo. É um estudo que deveria dar suporte a tal planejamento.

Nesse cenário de indefinição surge o PAC, que escolhe obras sem justificativas claras, preterindo as indicadas pelo PNLT e até inviabilizando investimentos com alta prioridade, como o caso da hidrovia Teles-Pires Tapajós, indicando a construção de hidrelétricas sem eclusas.

A única comparação ou qualificação das opções de desenvolvimento - chamada pelo PNLT de priorização - decorre da avaliação implícita, apenas do objetivo 
econômico, realizada através de faixas de Taxa Interna de Retorno Econômico $(T I R E)^{13}$ e de Ano de Abertura de cada projeto - ainda com metodologia que merece críticas já que o Plano tem caráter apenas indicativo. A partir de suas indicações, deveriam ser feitas novas análises e estudos técnico-econômicos mais acurados para determinar suas reais viabilidades e prioridades.

A relevância do CO brasileiro é exaltada nos cálculos do PNLT. Dos seis agrupamentos que apresentam TIRE superior a 18\%, segundo cálculos do Plano, cinco afetam diretamente a região $\mathrm{CO}$. $\mathrm{Na}$ faixa de $12 \%$ a $18 \%$, metade dos investimentos também impacta a região (Tabela 13).

\footnotetext{
${ }^{13} \mathrm{~A}$ análise financeira de um projeto busca identificar o valor líquido gerado para o investidor (interessado direto). Em outras palavras, objetiva determinar se o projeto é interessante para alguém disposto a arcar com os investimentos e custos necessários para usufruir dos benefícios gerados.

$\mathrm{Na}$ análise econômica, por outro lado, avalia-se o efeito dos investimentos de um projeto sobre toda a economia. Seu objetivo pode ser entendido como insumo para verificar se um projeto representa a melhor utilização dos recursos durante o período de análise e compará-lo a outros.

Apesar da diferença conceitual, as duas análises podem ser semelhantes na forma pelo fato de ambas avaliarem o lucro de um investimento. Um equívoco comum na valoração de projetos é justamente não distinguir essas duas formas de análise.
} 
Tabela 13: TIRE e período recomendado de entrada das obras do PNLT. Fonte: PNLT (2007)

\begin{tabular}{|c|c|c|}
\hline AGRUPAMENTO & TIRE & $\begin{array}{c}\text { PERÍODO } \\
\text { RECOMENDADO } \\
\text { PARA } \\
\text { IMPLANTAÇÃO }\end{array}$ \\
\hline $\begin{array}{l}\text { Integração regional entre Acre, Rondônia, } \\
\text { Amazonas }\end{array}$ & abaixo 6\% a.a. & após 2015 \\
\hline $\begin{array}{l}\text { Interligação rodoviária entre Macapá (AP) e } \\
\text { Oiapoque (AP) }\end{array}$ & abaixo $6 \%$ a.a. & após 2015 \\
\hline $\begin{array}{l}\text { Pavimentação da rodovia BR } 230 \text { no estado do } \\
\text { Pará }\end{array}$ & $6 \%-12 \%$ a.a. & após 2015 \\
\hline Pavimentação do acesso à usina de Tucuruí (PA) & $6 \%-12 \%$ a.a. & após 2015 \\
\hline Rodovia BR 101 no estado da Bahia & Acima $24 \%$ a.a. & $2008-2011$ \\
\hline Prolongamento da rodovia MT 235 & acima $24 \%$ a.a. & $2008-2011$ \\
\hline Ligação rodoviária do Mato Grosso a Marabá (PA) & acima $24 \%$ a.a. & 2008-2011 \\
\hline Hidrovia Teles Pires - Tapajós & acima $24 \%$ a.a. & $2008-2011$ \\
\hline Hidrovia Tocantins & $12 \%-18 \%$ a.a. & 2012-2015 \\
\hline Ferrovia Norte Sul & $6 \%-12 \%$ a.a. & após 2015 \\
\hline Ligação Ferroviária Centro-Oeste - Pecém (CE) & $12 \%-18 \%$ a.a. & $2012-2015$ \\
\hline Ferrovia trecho Ribeirão Cascalheira - FNS & $18 \%-24 \%$ a.a. & 2012-2015 \\
\hline Hidrovia Araguaia - Tocantins & $18 \%-24 \%$ a.a. & 2012-2015 \\
\hline Hidrovia do rio Tocantins & $12 \%-18 \%$ a.a. & $2012-2015$ \\
\hline Ferrovia Bahia Oeste com destino a Aratu & abaixo 6\% a.a. & após 2015 \\
\hline Ferrovia Bahia Oeste com destino a Campinho & abaixo $6 \%$ a.a. & após 2015 \\
\hline Multimodal São Francisco - Juazeiro - Aratu & $12 \%-18 \%$ a.a. & $2008-2011$ \\
\hline $\begin{array}{l}\text { Ligação da região Oeste da Bahia até o Porto de } \\
\text { Suape (PE) }\end{array}$ & $12 \%-18 \%$ a.a. & após 2015 \\
\hline Ligação ferroviária Corumbá - Mairinque & abaixo 6\% a.a. & após 2015 \\
\hline Ferroanel de São Paulo - tramo Sul & abaixo 6\% a.a. & após 2015 \\
\hline Acesso à Ferrovia Transnordestina & abaixo 6\% a.a. & após 2015 \\
\hline Ferrovia Litorânea Sul & $12 \%-18 \%$ a.a. & $2012-2015$ \\
\hline Ferrovia do Frango & abaixo 6\% a.a. & após 2015 \\
\hline
\end{tabular}

Por apresentar falhas, principalmente quando confrontado com os itens necessários para um planejamento estratégico como descrito no item 2.1 - sem principalmente prescindir da definição de objetivos estratégicos no sentido mais amplo e de objetivos específicos -, o Plano não atendeu as expectativas de diversos agentes. Entre eles, a ANUT. 
A Associação Nacional dos Usuários de Transporte de Carga (ANUT), por exemplo, em dez/2008, divulgou um documento: "Transporte - Desafio ao Crescimento do Agronegócio Brasileiro", posterior ao PNLT e contemporâneo à elaboração desta dissertação, que pretendia:

Mostrar os estrangulamentos físicos e de gestão pública da logística do agronegócio, realçar o valor das ferramentas de planejamento que já temos à disposição, com seus detalhes que ainda carecem de aperfeiçoamento, e sugerir os comandos que a máquina estatal deve receber para capacitar o agronegócio a continuar crescendo de forma sustentada, em qualquer dos cenários que vier a estabelecesse na economia mundial: de recessão ou de bonança.

Os resultados apontados pela ANUT confirmam, na sua grande maioria, as afirmações feitas nesse trabalho, distanciando o PNLT de um verdadeiro planejamento estratégico de transportes.

O trabalho indica, entre outras coisas, a falta no Brasil de política nacional integrada em todos os níveis: municipal, estadual e federal, ou seja, um planejamento integrado; falta transformar o PNLT em instrumento de referência para elaboração de planos de curto prazo, ou seja, transforma-lo em um planejamento estratégico de longo prazo que possibilite a execução de planos no curto e médio prazo.

Realizar o planejamento, desenvolver um programa e disponibilizar recursos, sem, todavia, possuir um arcabouço institucional que permita executar de fato as obras, é infrutífero e representa um regresso à fase pré-planejamento. O PAC $1^{14}$ lançado pelo governo federal em 2007 enfrenta essas dificuldades.

O lançamento do PAC, em janeiro de 2007, revelou um portfólio de investimentos mais orientados a "tapar buracos" do que uma orientação estruturada e baseada em um planejamento estratégico, sendo um programa emergencial.

O PAC 1 englobou um conjunto de políticas econômicas para quatro anos (2007 2010) sem justificativas. Nesse primeiro programa foram previstos inicialmente $R \$$

\footnotetext{
${ }^{14}$ PAC 1: Com o lançamento do PAC 2 em 2010, o programa inicial passou a ser denominado de PAC 1, nome não usado durante o período de 2007 a 2010.
} 
503,9 bilhões de investimentos, sendo infraestrutura um dos setores prioritários, focado, entre outras, nas áreas de saneamento, habitação, transporte, energia e recursos hídricos.

Os investimentos em infraestrutura de transporte para o $\mathrm{CO}^{15}$, por exemplo, expostos no PAC 1, concentraram-se na recuperação ou pavimentação de rodovias e construção de ferrovias. O potencial hidroviário ${ }^{16}$ da região não foi abordado, não se prevendo investimentos nos rios Teles Pires, Tocantins, Araguaia ou rio das Mortes, que escoariam os produtos agrícolas do CO para o norte do país. A criação de um novo eixo de exportação é fortemente preconizada no PNLT e isso confirma a falta de harmonia entre o programa de ação e o planejamento.

Ainda antes da conclusão das obras previstas no PAC 1, em março de 2010 foi lançado o PAC 2, que previu investimentos de $R \$ 1,59$ trilhões adicionais para os segmentos de transporte, energia, cultura, meio ambiente, saúde, área social e habitação. O setor de transportes ficaria com aproximadamente $7 \%$ desse montante (Tabela 14).

Tabela 14: Distribuição entre os modais dos recursos do PAC 2 transportes. Fonte: PAC

\begin{tabular}{|l|c|c|c|}
\hline \multicolumn{1}{|c|}{ Eixos } & $\begin{array}{c}\mathbf{2 0 1 1 - 2 0 1 4} \\
\text { (R\$ bilhões) }\end{array}$ & $\begin{array}{c}\text { Pós 2014 } \\
\text { (R\$ bilhões) }\end{array}$ & $\begin{array}{c}\text { Total } \\
\text { (R\$ bilhões) }\end{array}$ \\
\hline Rodovias & 48,4 & 2,0 & 50,4 \\
\hline Ferrovias & 43,9 & 2,1 & 46,0 \\
\hline Portos & 4,8 & 0,3 & 5,1 \\
\hline Hidrovias & 2,6 & 0,1 & 2,7 \\
\hline Aeroportos & 3,0 & - & 3,0 \\
\hline $\begin{array}{l}\text { Equipamentos para } \\
\text { estradas vicinais }\end{array}$ & 1,8 & - & 1,8 \\
\hline \multicolumn{1}{|c|}{ Total } & $\mathbf{1 0 4 , 5}$ & $\mathbf{4 , 5}$ & $\mathbf{1 0 9 , 0}$ \\
\hline
\end{tabular}

As implementações das obras vem sofrendo constantes paralisações por ações, entre outros, do Tribunal de Contas da União (TCU). Esse órgão apontou em 2008

\footnotetext{
${ }^{15} \mathrm{~A}$ região Centro-Oeste do Brasil será o foco das análises de infraestrutura de transportes. Sua importância será descrita no capítulo 3.2.

${ }^{16}$ Exceção feita à hidrovia Paraguai - Paraná, que constava no Programa.
} 
irregularidades em aproximadamente $30 \%$ das obras do PAC, das quais 13 sofreram recomendação de paralisação ${ }^{17}$.

No décimo balanço do PAC 1, divulgado em abril de 2010, apenas 46,1\% do orçamento destinado para o período 2007 - 2010 havia sido executado em obras finalizadas (Gráfico 1). Do montante destinado a ações de logística, energia e social e urbanismo, esse valor é ainda menor: 33,6\%.

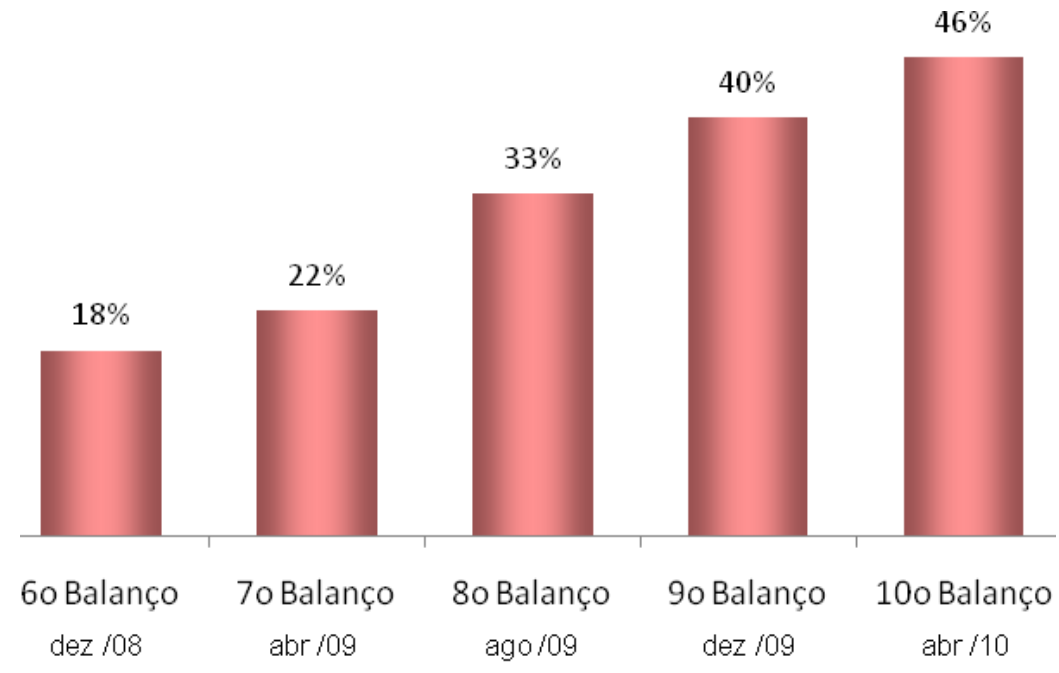

घ \% em R\$ ações concluídas

Gráfico 1: Balanço de evolução das obras do PAC 1 - inclui habitação e saneamento. Fonte:

PAC

Excluindo a parcela da marinha mercante ( $R$ \$ 11,6 bilhões), associada a financiamento de embarcações e estaleiros, o modal rodoviário consumiu $95 \%$ dos recursos. Apesar da intenção de desafogar o modal rodoviário e redistribuir o transporte de carga aos demais modais, as irrisórias quantias investidas em portos e hidrovias tornam a harmonização entre os modais pouco provável (Gráfico 2).

\footnotetext{
${ }^{17}$ Fonte: TCU: 13 obras do PAC apresentam graves irregularidades. Jornal Estado de São Paulo - 30 de setembro de 2008.
} 


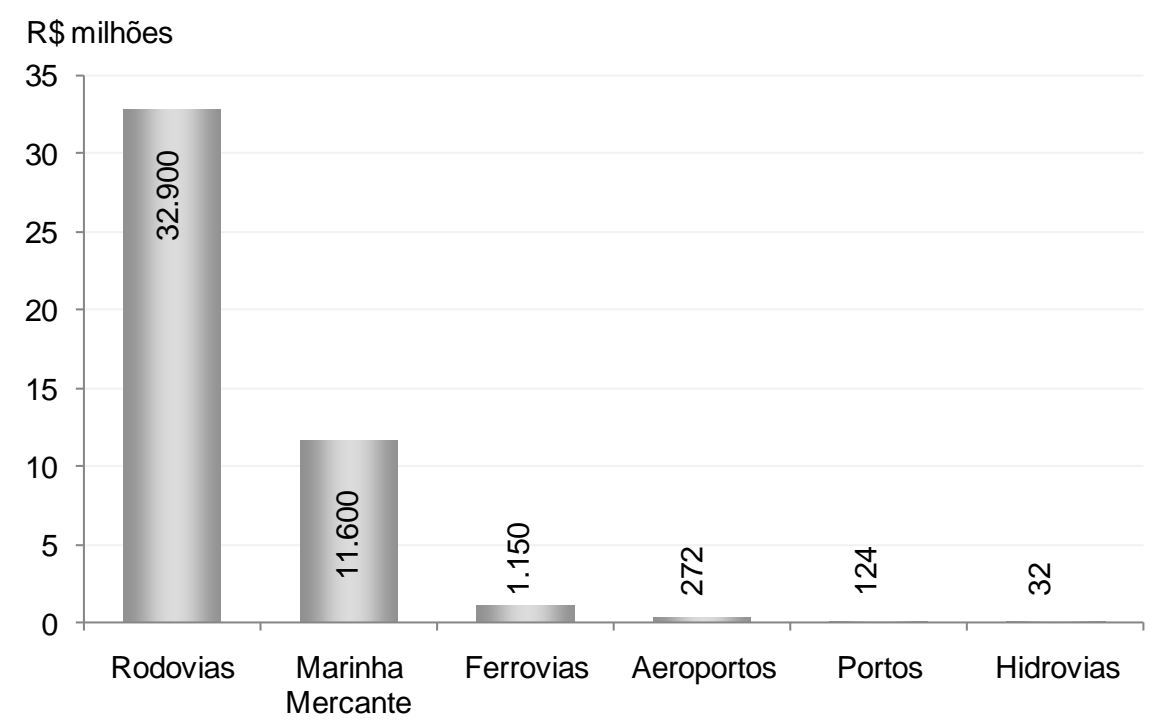

Gráfico 2: Recursos do PAC investidos até Abril de 2010 em logística de transportes. Fonte:

\section{PAC}

Confrontando os investimentos previstos no PAC com os objetivos do PNLT, percebe-se, novamente, o distanciamento de ambos. O plano intitulado como estratégico prevê a mudança da matriz de transportes, diminuindo a participação do modal rodoviário dos atuais 58\% para 33\% em 2023 (Gráfico 3), no entanto o PAC investe $95 \%$ dos seus recursos em rodovias.

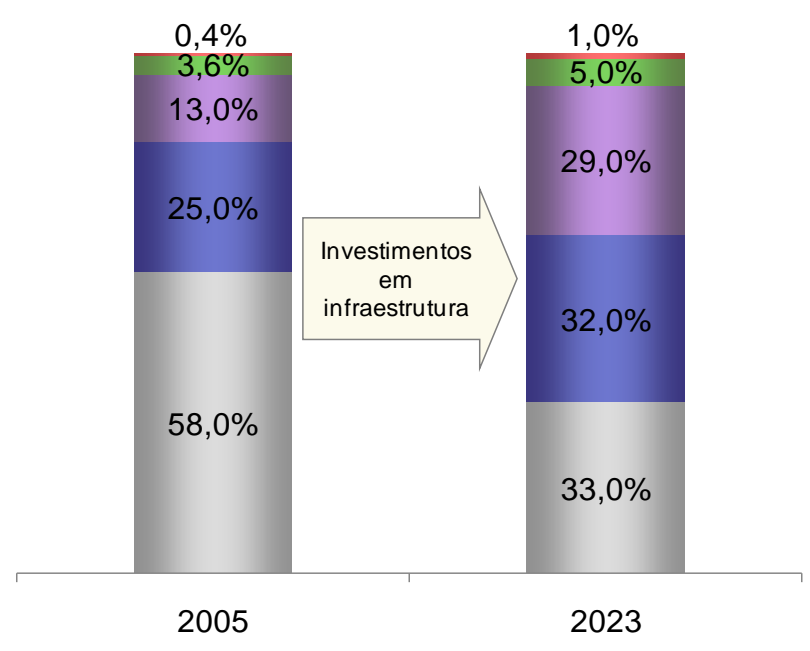

$\square$ Rodoviário $\square$ Ferroviário $\square$ Hidroviário $\square$ Dutoviário $\square$ Aeroviário

Gráfico 3: Meta da distribuição de carga entre os modais para o ano de 2023, após implantação das obras do PNLT. Fonte: PNLT (2007) 
Pode-se entender o PAC como um plano emergencial, disponibilizando recursos para melhorar a qualidade dos modais existentes, privilegiando, portanto, o modal de maior relevância. Apesar de não anular as críticas feitas, isso pode justificar, a princípio, o distanciamento com o planejamento estratégico.

Nota-se que, apesar de um grande avanço por parte do governo federal em direção ao planejamento, a existência de uma lista de obras ou a disponibilidade de recursos financeiros não são fatores que por si só solucionariam por completo os problemas de infraestrutura do país. Outros objetivos como discutidos no item 2.1 deveriam estar presente e priorizados num documento de planejamento estratégico. 
3 Contextualização 


\subsection{Investimentos no setor de transportes: Desenvolvimento recente no Brasil}

O forte crescimento econômico brasileiro entre as décadas de 70 e 80 foi interrompido a partir da severa deterioração de parâmetros macroeconômicos como inflação e dívida pública, que resultou em cortes nos investimentos. A crise teve sua semente com o primeiro choque do petróleo em 1973 e agravou-se em razão do segundo, em 1979, encarecendo demasiadamente o petróleo, e tornando a dívida externa e a inflação praticamente insustentáveis. O cenário de crise configurou-se em meados dos anos 80 .

O aumento da dívida externa fez o governo brasileiro decretar a primeira moratória da dívida em 1982, o que resultou na queda de sua credibilidade no cenário internacional. Cada novo empréstimo necessário para "rolar" a dívida tornava-se mais caro, fazendo com que o governo cortasse mais investimentos. Em 1987 foi decretada a segunda moratória no Governo de José Sarney.

Segundo Calheiros (2007), a inflação de $85 \%$ ao mês forçou a indexação dos preços e salários. Toda receita gerada era praticamente destinada ao pagamento da dívida externa, nomeando o período como a década perdida.

O PIB cresceu apenas 2,0\% a.a. entre 1980 e 2002 contra 7,4\% entre 1962 e 1980 com investimento médio de $0,4 \%$ a.a. e 9,9\% a.a., respectivamente (Gráfico 4$)^{18}$.

\footnotetext{
${ }^{18}$ Fontes: Banco Central do Brasil (BACEN) e Instituto de Pesquisa Econômica Aplicada (IPEA). O crescimento anual é dado pelo CAGR.
} 


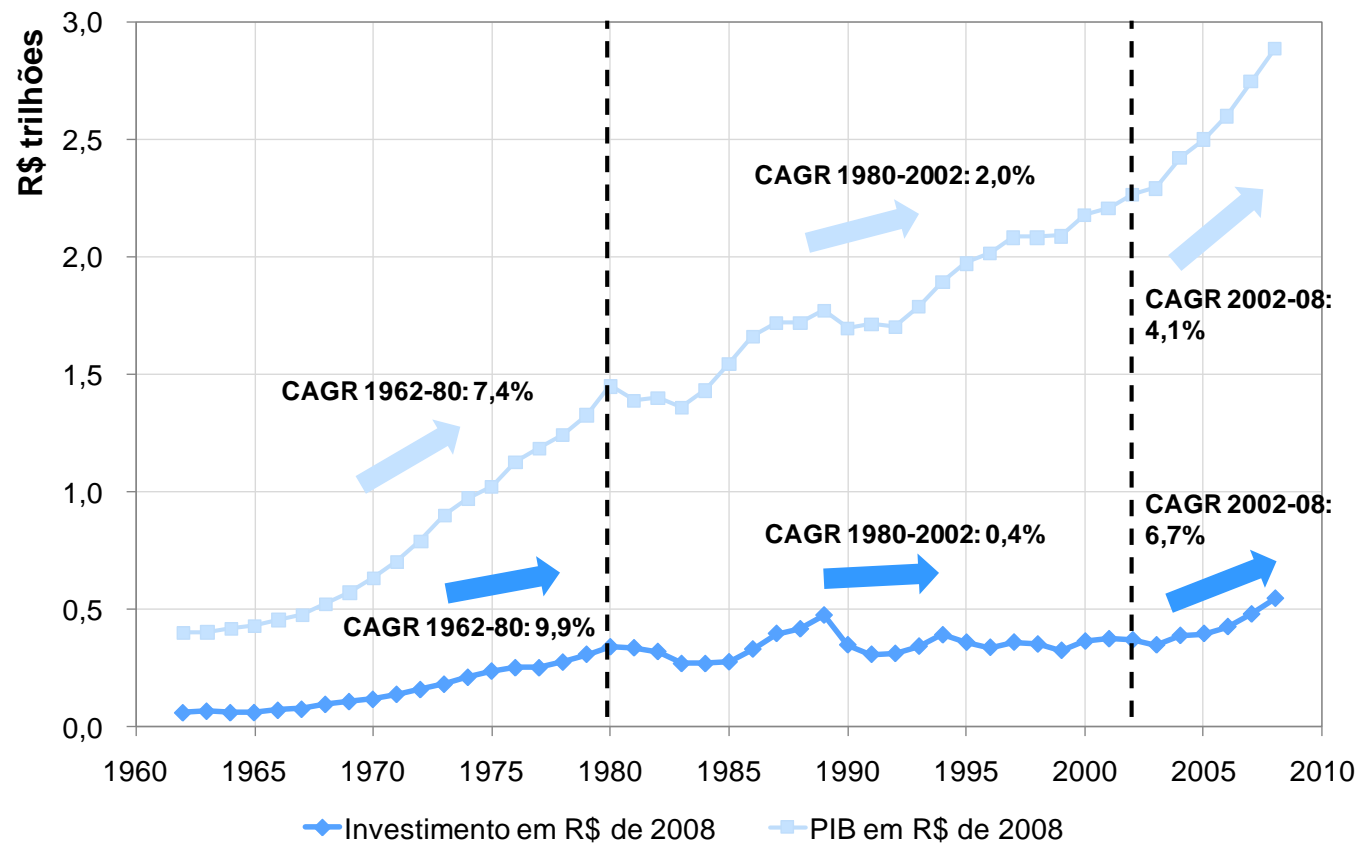

Gráfico 4: Variação anual do PIB e do investimento total em R\$ de 2008, entre 1962 e 2008.

Fonte: Banco Mundial / Goldberg (2009)

Como aponta Goldberg (2009), na segunda metade dos anos 80, houve uma queda na proporção do PIB investido em infraestrutura pelo poder público, valores que se mantiveram baixos ao longo da década seguinte. Na década de 90 , a proporção do PIB investido pelo setor privado superou o público (Gráfico 5).

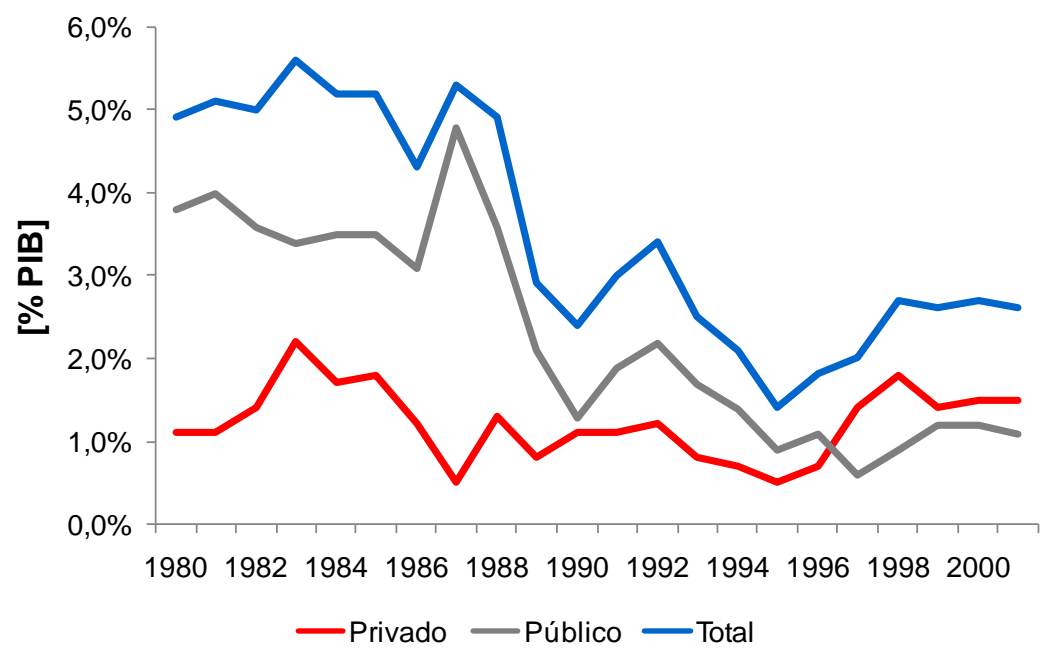

Gráfico 5: Taxa de investimento em infraestrutura no Brasil entre 1980 e 2001 (\% PIB). Fonte: Banco Mundial / Goldberg (2009)

Ao longo das décadas anteriores a de 90, diversas empresas públicas haviam sido criadas por iniciativa do governo ou pela absorção de empresas privadas em 
dificuldade financeira. A redução gradual dos investimentos públicos orientou a deterioração da infraestrutura existente, tornando-a obsoleta.

A década de 90 foi marcada por processos de inserção da iniciativa privada em diferentes setores, a quem o poder público recorreu diante da urgência da restauração e da ampliação das obras e da necessidade de melhorias de gestão e operação dos serviços públicos.

A desestatização era um meio para atrair investimentos privados para setores de infraestrutura que pudessem ser explorados pela iniciativa privada, liberando divisas para aqueles cujos recursos governamentais são imprescindíveis (saúde, educação básica, etc.). O processo traria também aumento da capacidade e eficiência da produção e os recursos obtidos poderiam ser usados para reduzir a dívida pública.

O programa de desestatização só pôde ser efetivamente implantado quando o Plano Real trouxe estabilidade à economia e obteve sucesso no controle da inflação. A estabilização foi obtida, mas o governo teve que manter altas taxas de juros para inibir a demanda e atrair capital ${ }^{19}$. O serviço da dívida deixava ao governo poucos recursos para investimento em infraestrutura. Foi mais uma década de reduzido crescimento médio do PIB.

Assim, segundo Portugal (2008), entre 1996 e 2001 o Estado brasileiro reduziu intensamente sua participação em alguns setores de infraestrutura. No início da década de 2000, os serviços de telecomunicações e as ferrovias eram praticamente todos controlados pelo setor privado. Nos maiores portos, os terminais arrendados já respondiam por mais de $50 \%$ das cargas movimentadas. No setor elétrico, mais de dois terços da distribuição e mais de um quinto da geração de energia eram realizadas por empresas privadas.

Entre 2002 e 2008, no mandato do Presidente Lula, tanto o crescimento do PIB (CAGR de $4,1 \%$ a.a.) quanto o ritmo de investimentos foram retomados (CAGR de 6,7\% - Gráfico 4).

\footnotetext{
${ }^{19}$ O país ainda sofria de baixa credibilidade internacional e com falta de liquidez em épocas de crises internacionais (crise dos Tigres Asiáticos, da Rússia, etc.).
} 
Dentre os serviços públicos desestatizados, os que mais geraram investimentos foram os de energia e telecomunicações, segundo Portugal (2008) (Gráfico 6). O autor destaca como principais motivos a criação adequada da estrutura institucional antes da desestatização, os aumentos substanciais da tarifa para por fim às estruturas de subsídio cruzado e a criação de incentivos adequados à competição, com regras pré-definidas.

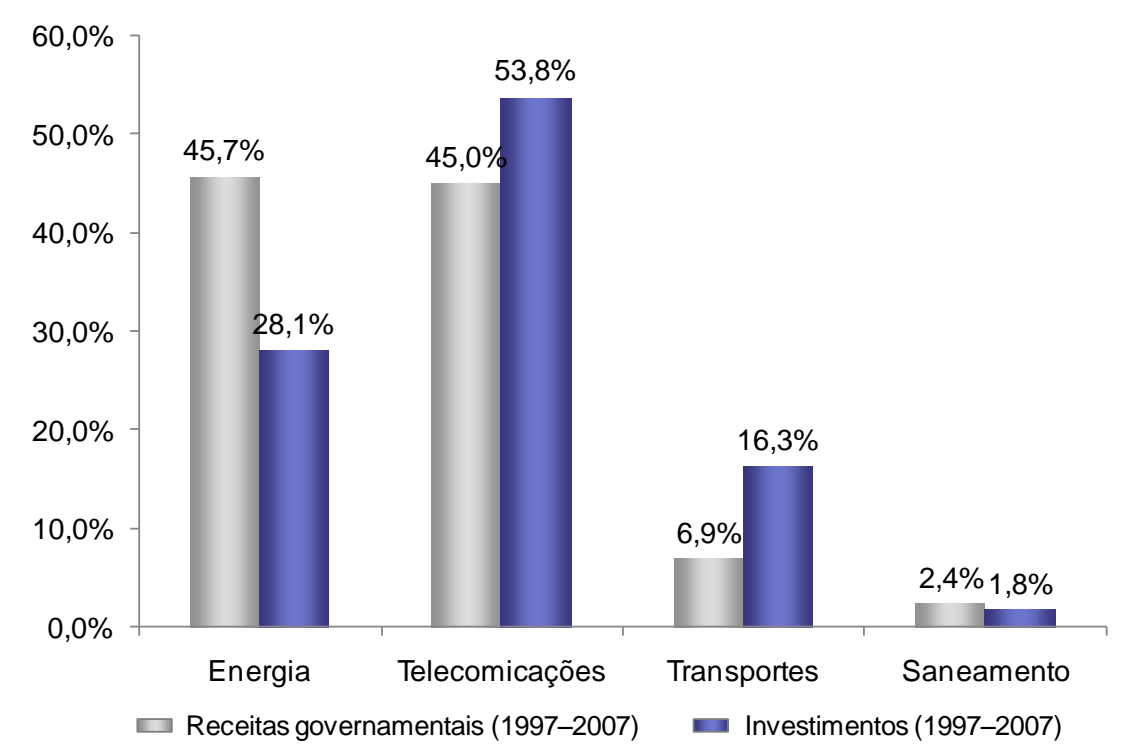

Gráfico 6: Receita governamental e investimentos em quatro setores públicos básicos. Fonte: Portugal (2008)

Além desses fatores, cabe citar que naqueles setores houve privatização de fato ${ }^{20}$, com a venda de empresas públicas, ao passo que no setor de transportes os serviços foram concedidos, gerando menor receita para o governo. Este fator, segundo De Paula e Avelar (2008), explica em parte porque as agências reguladoras de transporte tiveram, do poder público, menos atenção e menos recursos do que as agências de energia e de telecomunicações.

A política econômica mantida desde a gestão do Presidente Fernando Henrique Cardoso, aliada ao cenário externo favorável, resultou no aumento expressivo do comércio exterior brasileiro e da demanda por infraestruturas logísticas. Esse

\footnotetext{
${ }^{20}$ Privatização de fato com venda direta de ativos ou mediante oferta de ações.
} 
fenômeno revelou, por sua vez, a necessidade de ampliar de forma significativa a capacidade em algumas partes da rede intermodal brasileira.

Sob a bandeira do "espetáculo do crescimento", foi lançado, em 2007 (com horizonte inicial de 2010), o PAC $1^{21}$, que possuía como pilares o investimento público e a desoneração tributária para incentivar investimentos privados em infraestrutura. No entanto, como já comentado, os investimentos estão acontecendo muito lentamente, em descompasso com as necessidades do país.

Apesar desses poucos avanços apresentados nas obras do PAC 1, em março de 2010, foi lançado, com viés eleitoreiro, o PAC 2 com horizonte de mais 4 anos, que está fadado ao mesmo destino do primeiro programa caso a gestão não seja alterada.

${ }^{21}$ O PAC é coordenado pelo Comitê Gestor do PAC (CGPAC), composto pelos ministros da Casa Civil, da Fazenda e do Planejamento. Há também o Grupo Executivo do PAC (GEPAC), que busca estabelecer metas e acompanhar a implementação do PAC, integrado pela Subchefia de Articulação e Monitoramento (Casa Civil), Secretaria de Orçamento Federal e Secretaria de Planejamento e Investimentos Estratégicos (Planejamento), além da Secretaria Nacional do Tesouro (Fazenda). 


\subsection{A região Centro-Oeste: a nova fronteira agrícola}

A expansão da fronteira agrícola no Centro-Oeste teve início somente na década de 40, com principal objetivo de atender à demanda de produtos primários para a região Sudeste. Com a construção de Brasília, essa ocupação se acentuou, e ocorreu de forma definitiva a partir da década de 80 .

Essa região apresenta grande potencial agrícola e deverá exercer o papel de fonte de alimentos num cenário de escassez mundial de áreas agriculturáveis. No entanto, esse papel pode ser anulado, pois sua infraestrutura de transportes está estágio incipiente de desenvolvimento, sendo a região mais afetada pelo chamado "apagão logístico".

Assim, por ser a região de maior potencial de crescimento agrícola e apresentar uma infraestrutura de transportes precária, ela será o foco do exercício apresentado nesta dissertação. O fornecimento de alimentos só será concretizado caso haja planejamento estratégico da sua malha multimodal de transportes.

\subsubsection{A grande região na agricultura}

A região Centro-Oeste, composta por Mato Grosso (MT), Mato Grosso do Sul (MS), Goiás (GO) e Distrito Federal (DF), possui 157 Mha - 18,5\% do Brasil -, dos quais $10 \%$ são plantados. A área plantada da região representa $30 \%$ do total nacional e mostra expressiva taxa de crescimento, $6,5 \%^{22}$ a.a. de 98 a 08 , praticamente o dobro da média nacional, de 3,3\% a.a. (Gráfico 7).

${ }^{22}$ CAGR. 


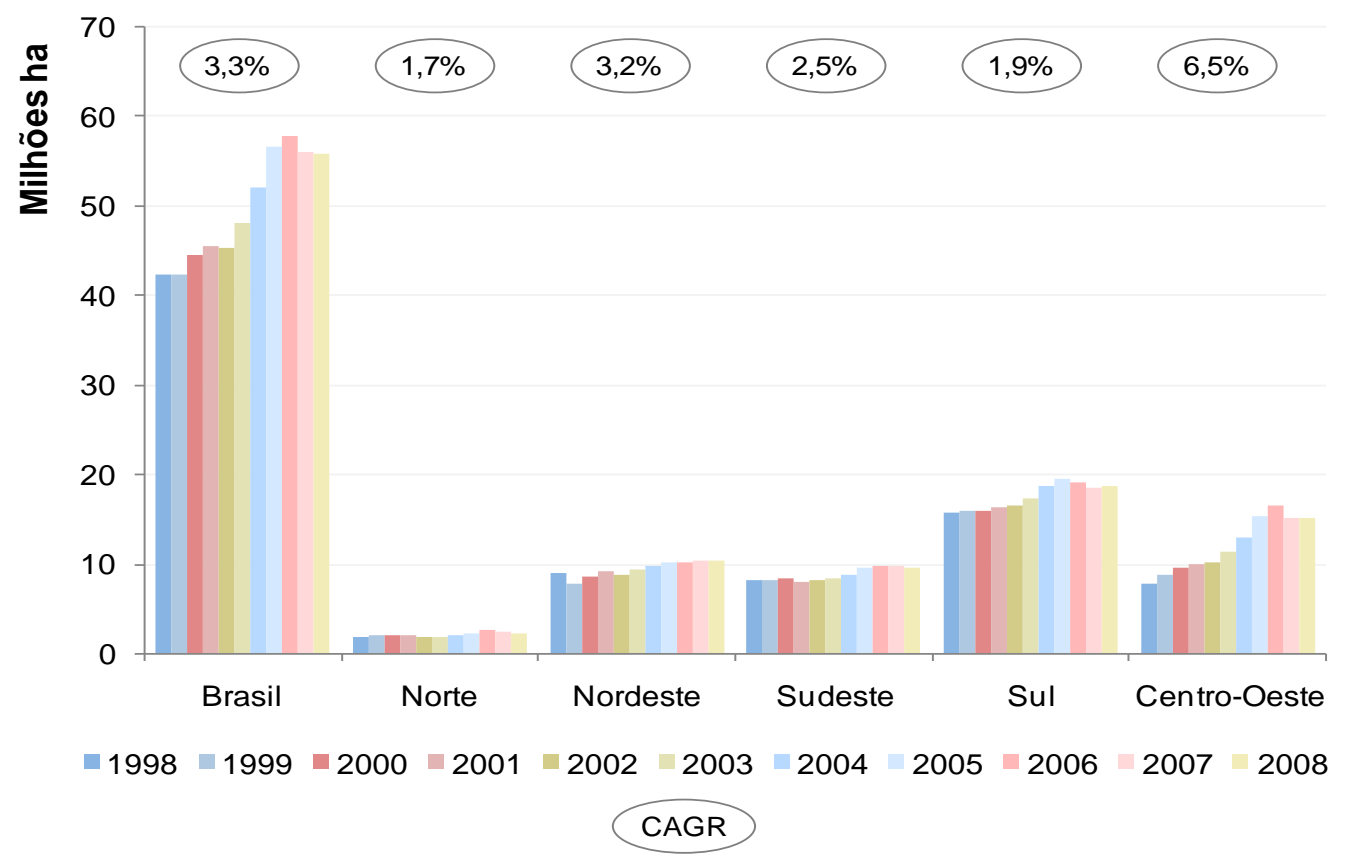

Gráfico 7: Evolução da área plantada nacional e por região. Fonte: IBGE / elaboração: autor

A produção dos três estados representou 15\% (125 Mt) do total nacional em 2008, perdendo apenas para a região Sudeste com 56\% (470 Mt $)^{23}$, a qual apresenta crescimento em área plantada abaixo da média nos últimos anos, 2,5\% a.a..

Os principais produtos agrícolas da região são cana-de-açúcar, milho e soja que juntos reuniram $93 \%$ do total da produção ${ }^{24}$ do CO em 2008, com 56\%, 14\% e 23\% respectivamente. Comparando com o cultivo nacional, $11 \%$ da cana-de-açúcar, 30\% do milho e $48 \%$ da soja foram produzidos nessa região no mesmo ano.

Resultado da intensificação do plantio em novas áreas, a partir da década de 90 iniciou-se um movimento de expansão das áreas de produção agrícola da região para o norte do país (Figura 7). Além da disseminação da produção, percebe-se o crescimento das áreas plantadas nas regiões já produtoras, resultando numa maior ocupação do terreno com agricultura.

\footnotetext{
${ }^{23}$ A região Sudeste do Brasil possui 95\% (em peso) da sua produção em cana-de-açúcar.

${ }^{24}$ Fonte: IBGE
} 


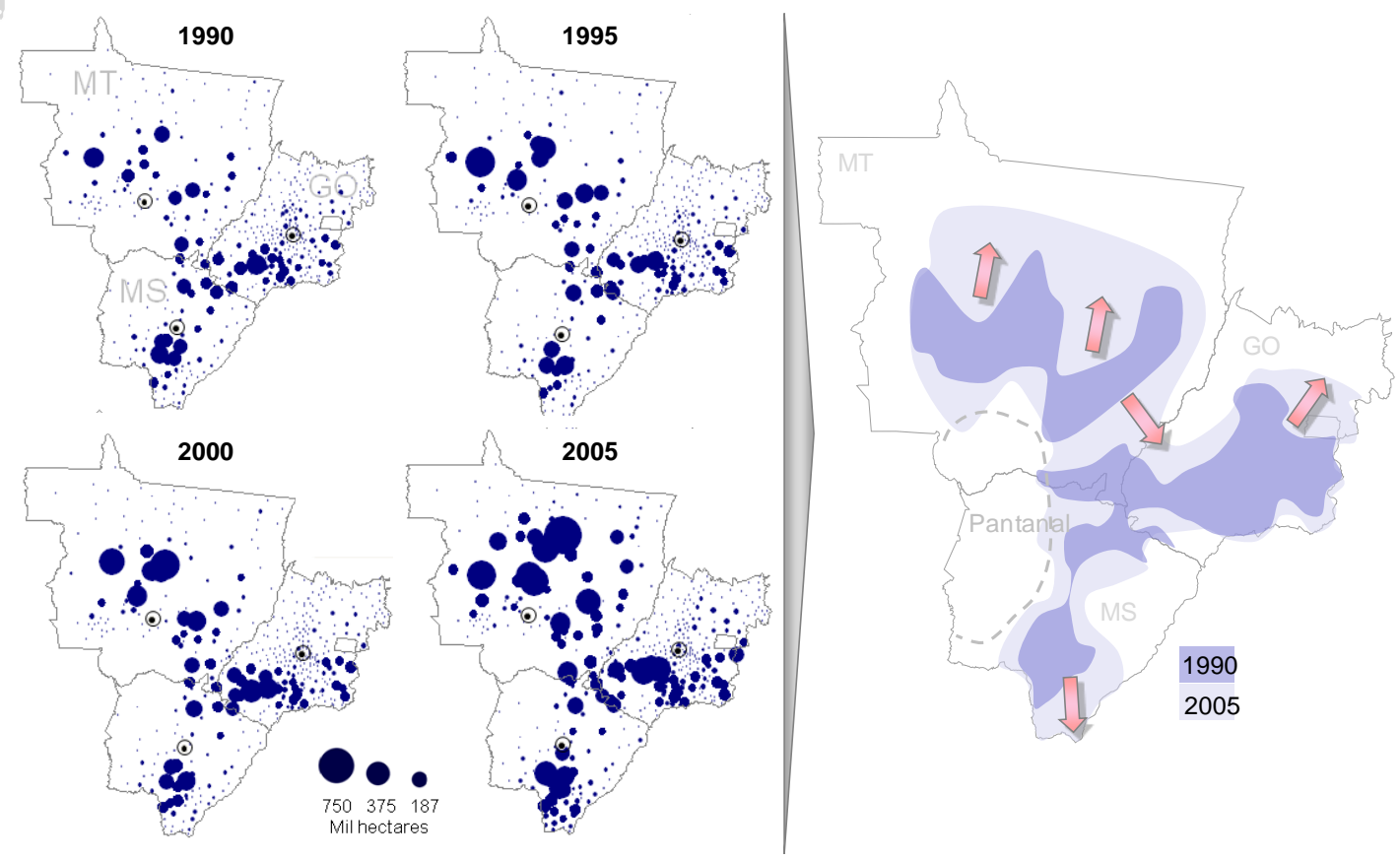

Figura 7: Avanço das áreas plantadas no CO de 1990 a 2005. Fonte: Adaptado de CEGN (2010)

Mesmo com a evolução apresentada nos últimos anos, ainda existem no CO 80 Mha disponíveis ${ }^{25}$ para a agricultura, que somadas com a área plantada atual atingiriam aproximadamente 96 Mha. O MT é o estado com maior disponibilidade com 54\% do total, seguido por MS e GO com $24 \%$ e $22 \%$, respectivamente (CEGN, 2010).

Seguindo o ritmo de crescimento atual da produção e com as produtividades médias ponderadas ${ }^{26}$ verificadas da região, projeta-se para 2023 uma produção ${ }^{27}$ de aproximadamente $182 \mathrm{Mt}$.

\footnotetext{
${ }^{25}$ Para a região que possui grande potencial agrícola a determinação da área disponível foi feita com a diferença entre área plantada e área agriculturável, onde a área agriculturável é resultado da subtração de áreas inadequadas (cidades, estradas, restrições ambientais, entre outras) da área total do estado.

${ }^{26}$ Produtividade média ponderada: Ponderação utilizando a produtividade média de cada produto e a área plantada no estado.

${ }^{27}$ Considerando a produção de soja, milho e cana-de-açúcar em toda a área disponível para agricultura.
} 
Tabela 15: Área plantada e produção por estado em 2023. Fonte: CEGN (2010)

\begin{tabular}{|l|c|c|c|}
\hline \multicolumn{1}{|c|}{ UF } & Área Plantada 2023 (mil ha) & Produtividade (t/ha) & Produção (mil t) \\
\hline Mato Grosso & $24.435,24$ & 4,17 & $101.798,26$ \\
\hline Mato Grosso do Sul & $6.653,88$ & 6,16 & $40.977,60$ \\
\hline Goiás & $4.577,56$ & 7,09 & $38.945,19$ \\
\hline CO & $\mathbf{3 5 . 6 6 6 , 6 8}$ & $\mathbf{5 , 0 9}$ & $\mathbf{1 8 1 . 7 2 1 , 0 5}$ \\
\hline
\end{tabular}

Apesar do grande crescimento projetado, as áreas agriculturáveis do CO não se esgotariam no horizonte de tempo analisado, restando aproximadamente 60 Mha. Esse espaço adicional poderia triplicar a área plantada projetada para 2023 elevando a produção para cerca de $480 \mathrm{Mt}$ anuais de grãos.

\subsubsection{A pequena região em infraestrutura}

Apesar da posição de destaque ocupada no cenário agrícola, a infraestrutura do CO apresenta os piores indicadores do corredor Centro-Sul (Centro-Oeste, Sudeste e Sul), tanto em quantidade, quanto em qualidade de vias.

A densidade de vias - extensão de vias $(\mathrm{Km})$ / área total do estado $\left(\mathrm{km}^{2}\right)$ - dos três estados da região é menor que PR, SP, SC, RS e MG. Comparando com PR e RS, o estado de MT, por exemplo, possui $92 \%$ e $80 \%$ menos rodovias $/ \mathrm{km}^{2}$, respectivamente (Gráfico 8). 


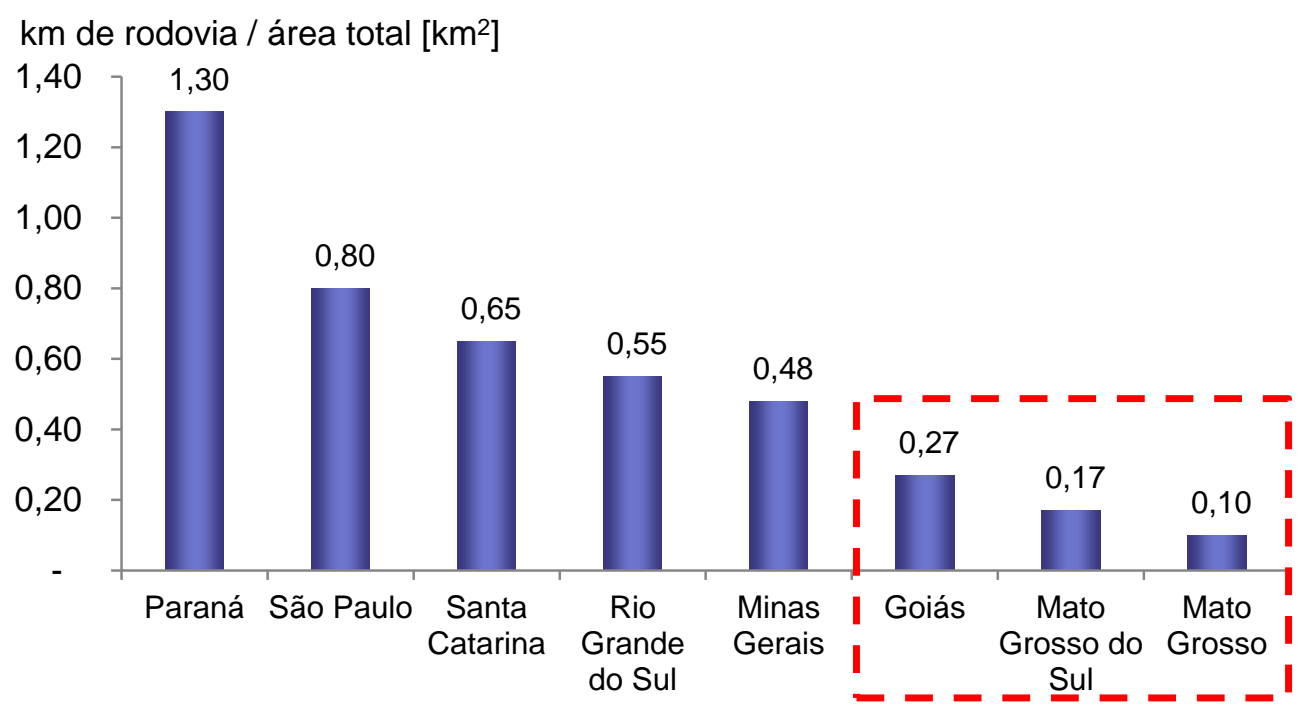

Gráfico 8: Comparação entre estados de densidade de rodovias (extensão de rodovias/ área total). Fonte de dados: IBGE e GEIPOT (2001) / elaboração: autor

A comparação por área pode parecer injusta, pois os estados possuem dimensões consideravelmente diferentes. No entanto, ao analisar o índice por área plantada, a situação dos três estados permanece a mesma, ocupando as quatro últimas posições - nesse indicador o estado do Rio Grande do Sul figura entre os estados do CO.

Tabela 16: Área plantada por estado. Fonte de dados: IBGE / elaboração: autor

\begin{tabular}{|l|r|}
\hline UF & Área plantada (ha) \\
\hline Paraná & 9.054 .166 \\
\hline Mato Grosso & 8.009 .276 \\
\hline Rio Grande do Sul & 7.783 .099 \\
\hline São Paulo & 5.838 .923 \\
\hline Goiás & 4.040 .749 \\
\hline Minas Gerais & 3.547 .511 \\
\hline Mato Grosso do Sul & 3.004 .163 \\
\hline Santa Catarina & 1.714 .457 \\
\hline Brasil & 56.069 .983 \\
\hline
\end{tabular}




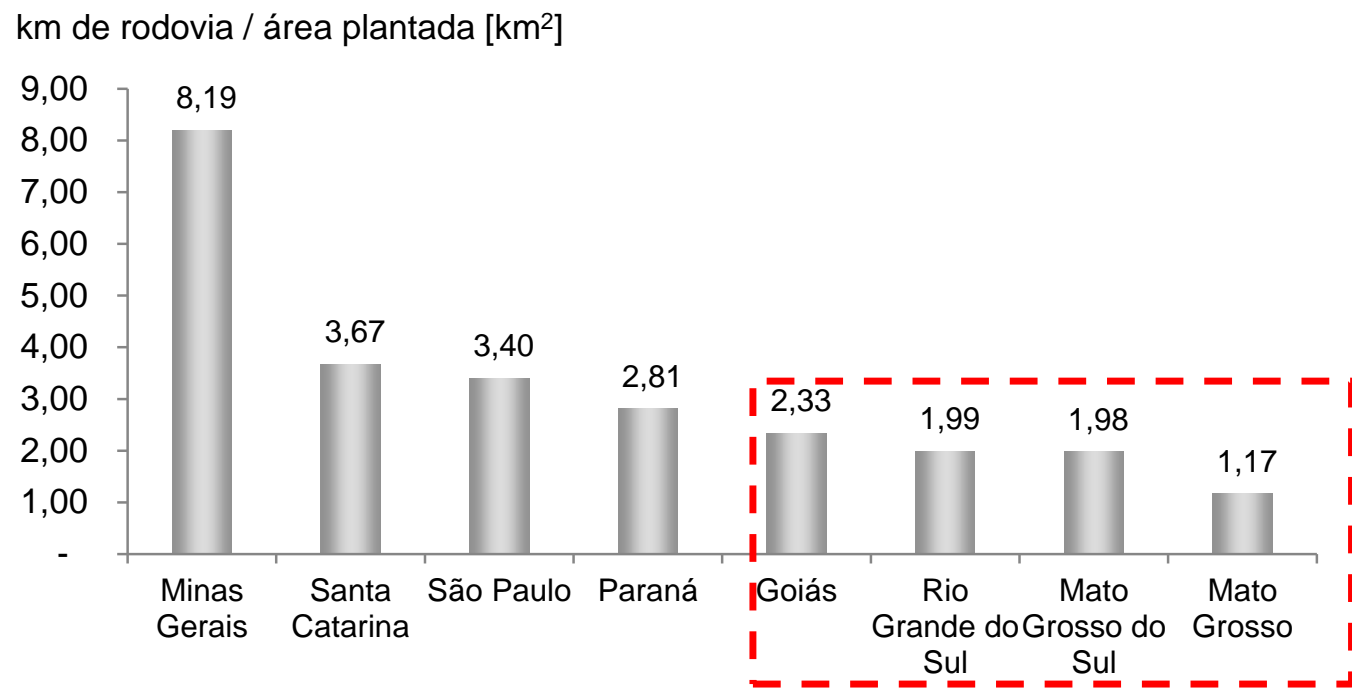

Gráfico 9: Comparação entre estados de densidade de rodovias (extensão de rodovias/ área plantada). Fonte de dados: IBGE e GEIPOT (2001) / elaboração: autor

Além da pequena extensão, as vias ainda apresentam péssimas condições. Goiás é o estado que apresenta os melhores indicadores ${ }^{28}$, com apenas $27 \%$ das rodovias classificadas como boas ou ótimas, valor bastante baixo comparado aos $75 \%$ do estado de São Paulo (Gráfico 10).

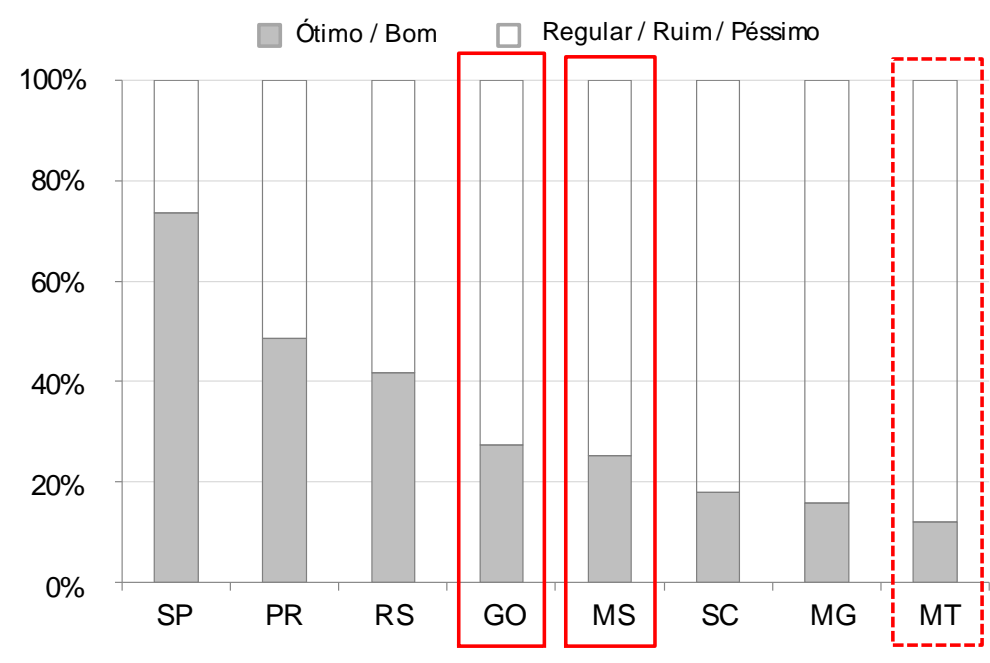

Gráfico 10: Condição da malha rodoviária. Fonte: CNT (2006) /destaques: autor

${ }^{28}$ Fonte: CNT (2006). 
O cenário que se desenha para a região é pouco favorável ao seu desenvolvimento. Apesar de enorme potencial agrícola, caso os planos expostos pelo governo federal não sofram melhorias significativas, os produtos perderão competitividade no mercado internacional devido aos altíssimos, brecando o desenvolvimento da região.

\subsubsection{Mapeamento e avaliação das rotas disponíveis}

O escoamento da produção agrícola do CO é atualmente realizado por sete principais corredores de exportação ${ }^{29}$. Cinco desses têm como destino portos das regiões sul e sudeste, e apenas dois direcionam-se aos portos da região Norte (Figura 8) - dois corredores ${ }^{30}$ com destino a Santos são representados pela mesma seta.

Cada corredor pode apresentar diversas opções de rotas, variando o modal utilizado e a distância percorrida até os terminais portuários.

\footnotetext{
${ }^{29}$ Inicialmente foram identificados os portos de destino das cargas do MT, MS e GO, por meio de dados de exportação (Fonte: Sistema de Análise das Informações de Comércio Exterior via Internet, denominado AliceWeb, da Secretaria de Comércio Exterior (SECEX), do Ministério do Desenvolvimento, Indústria e Comércio Exterior (MDIC)). Em seguida, foram localizadas as cidades de maior produção das grandes regiões produtoras, tomando-as como polos emissores de carga. Por fim, foi possível mapear as rotas utilizadas até os portos com informações disponibilizadas pela CONAB, obtidas por meio de contato com delegados de núcleos produtores e entrevista com caminhoneiros.

${ }^{30}$ Os corredores Sorriso-Santos e Maracaju-Santos foram representados por uma única seta.
} 


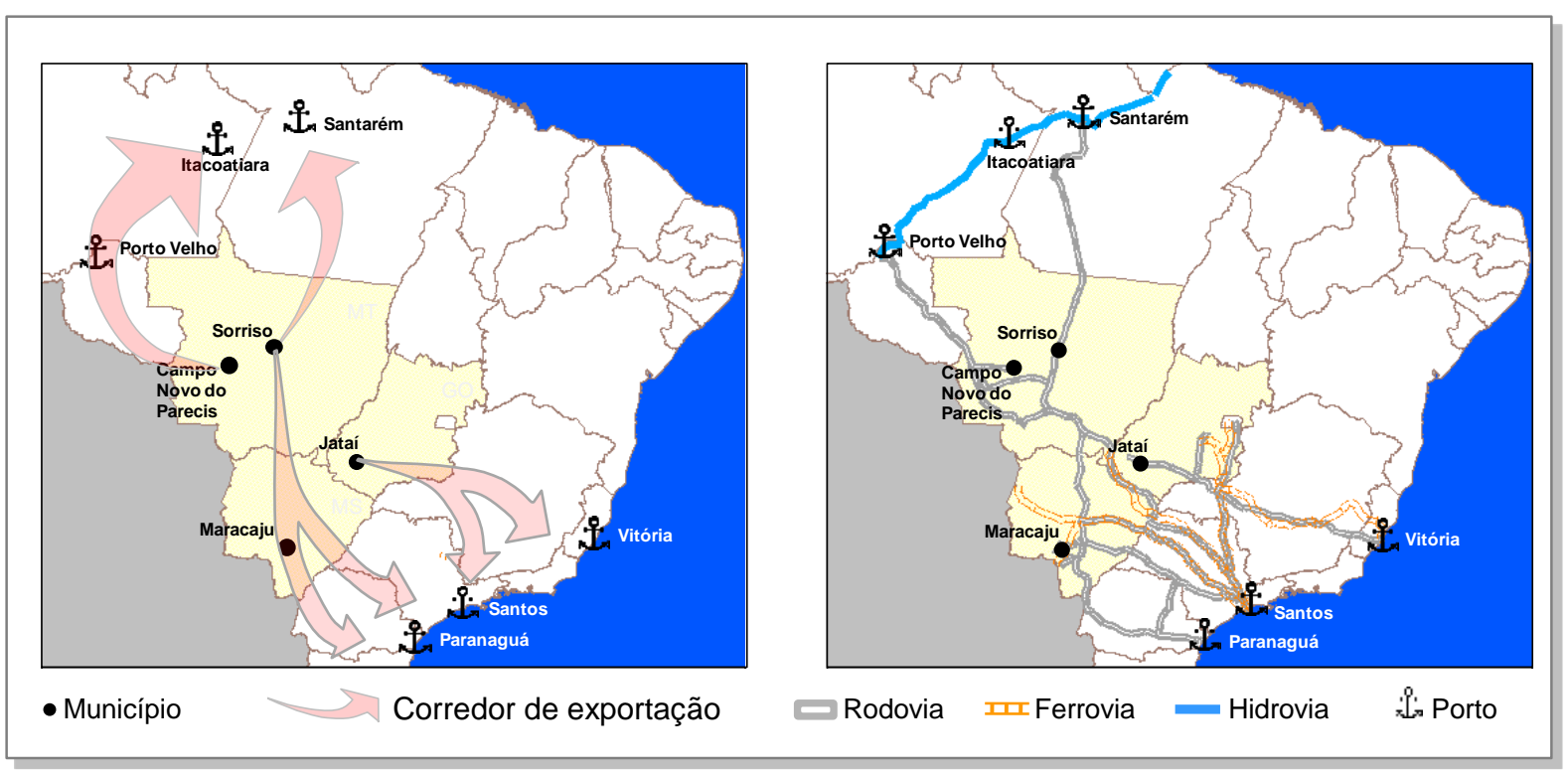

Figura 8: Corredores de exportação do Centro-Oeste e suas possíveis rotas. Fonte: elaboração autor

A classificação das condições de cada rota pode ser realizada através dos dados disponibilizados pela CNT. A CNT possui para as principais rodovias uma análise detalhada a cada $10 \mathrm{~km}$ especificando o estado - péssimo, ruim, regular, bom, ótimo - de pavimentação, sinalização e geometria da via. Esses fatores influenciam diretamente no conforto, segurança e velocidade média dos veículos, além dos custos operacionais resultando em aumento do frete.

Como os trechos de qualidade semelhante são longos e contínuos - ainda que avaliados a cada $10 \mathrm{~km}$ - é possível representa-los com boa visibilidade no mapa que segue.

Dos corredores de escoamento utilizados no transporte de cargas do $\mathrm{CO}$, as melhores condições de rodovias localizam-se em São Paulo e no Paraná. No Mato Grosso estão as piores rodovias (Figura 9). 


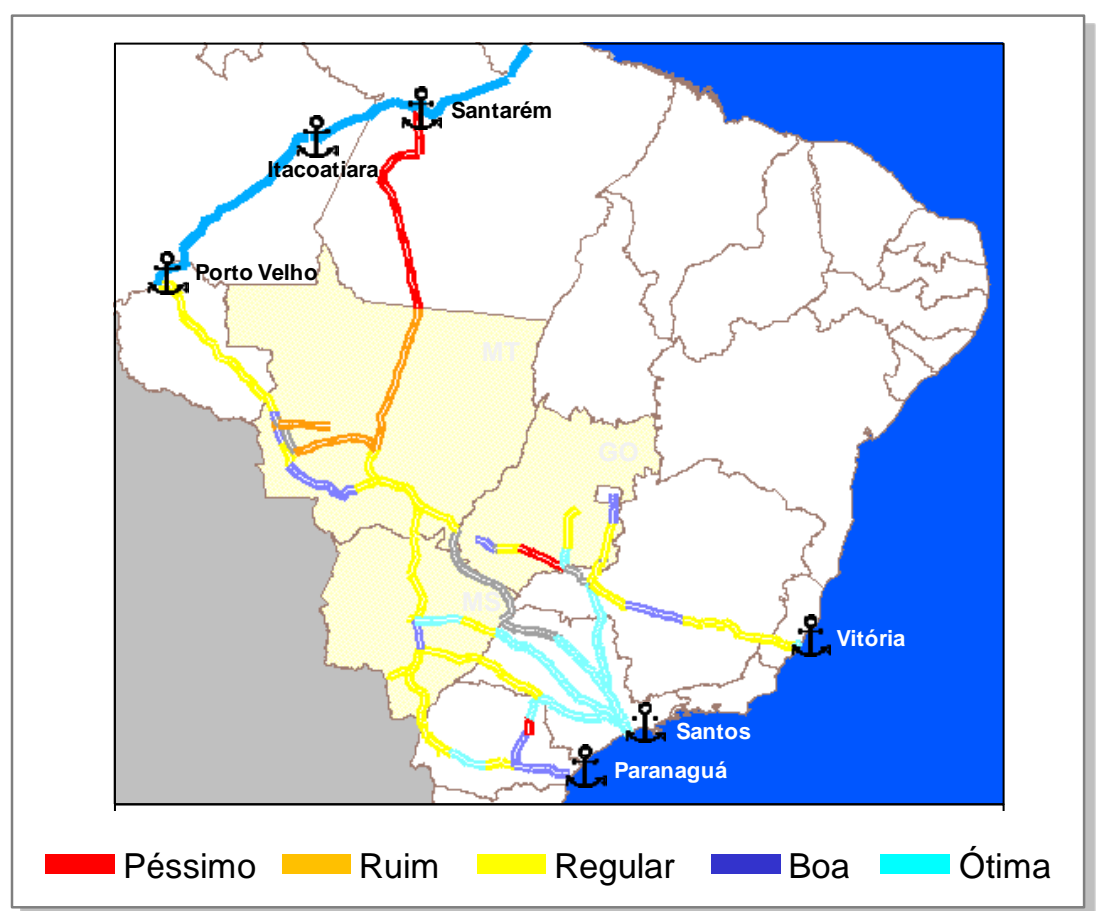

Figura 9: Condição das rodovias utilizadas para o escoamento da produção do Centro-Oeste. Fonte: elaboração autor

As ferrovias podem ser avaliadas segundo velocidade média e produção de cada trecho. A produção é analisada por dois parâmetros: Tonelada útil (TU), que se refere ao peso da carga transportada em determinado trecho, e tonelada quilômetro útil (TKU), que é o peso transportado multiplicado pela distância percorrida.

Por fim, as condições das hidrovias foram analisadas segundo dimensões do comboio tipo e calado máximo.

Os sete corredores de escoamento foram avaliados e são apresentados a seguir. 
- Corredor de Exportação Sorriso (MT) - Santos (SP)

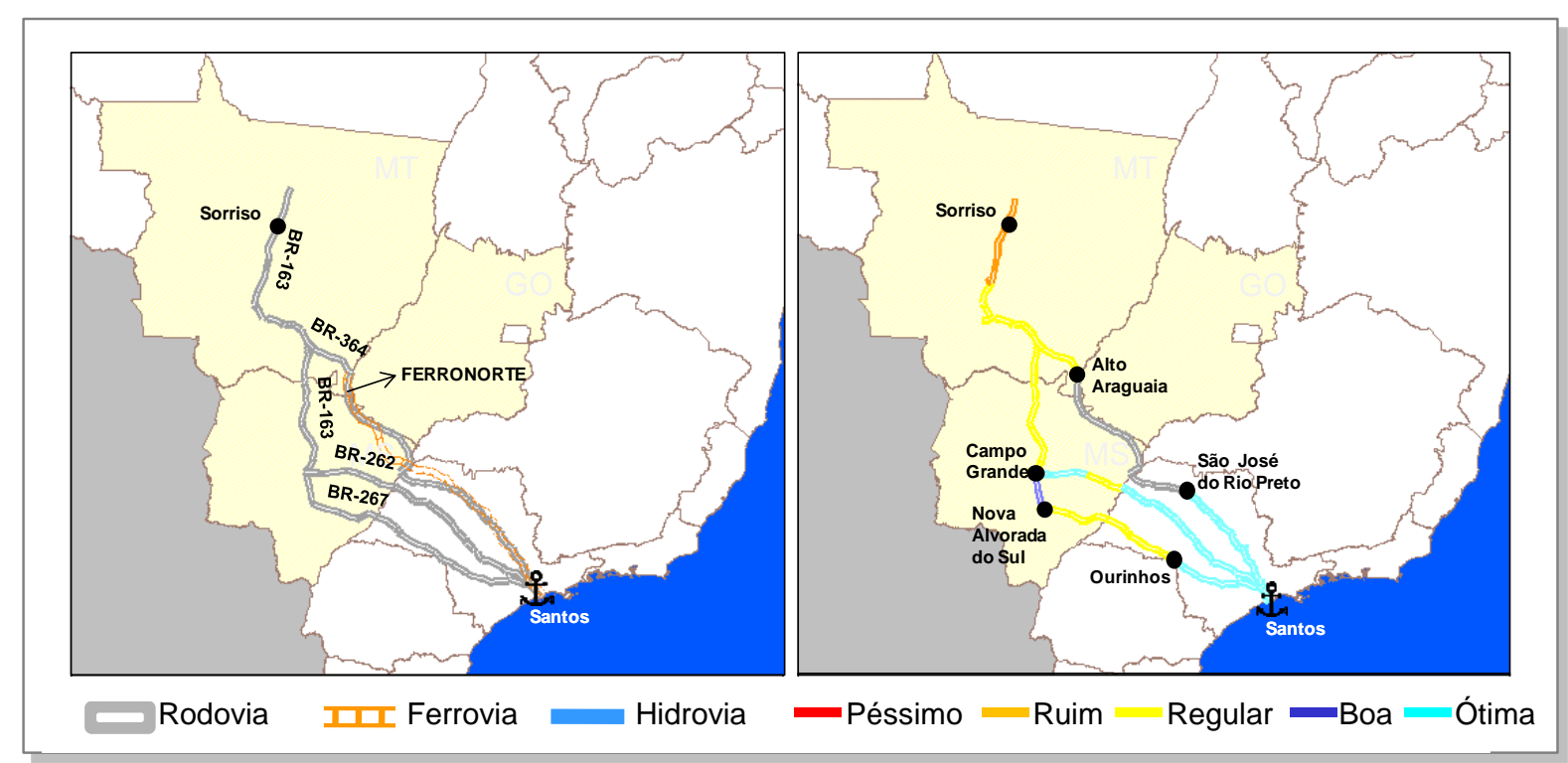

Figura 10: Mapeamento e condições do corredor de exportação Sorriso - Santos. Fonte: elaboração autor

É um dos corredores mais importantes do $\mathrm{CO}$, pois une o principal porto do país às regiões de maior produção do MT. Apresenta quatro rotas distintas, sendo três estritamente rodoviárias e uma rodoferroviária (Tabela 33).

Tabela 17: Detalhamento das rotas do corredor Sorriso - Santos. Fonte de dados: CNT (2006) / elaboração: autor

\begin{tabular}{|l|l|l|r|r|r|c|}
\hline Origem & Destino & \multicolumn{1}{|c}{ Vias utilizadas } & \multicolumn{3}{|c|}{$\begin{array}{c}\text { Distância } \\
\text { Rodo }\end{array}$} & $\begin{array}{c}\text { Condição } \\
\text { média da }^{\text {rota }}\end{array}$ \\
\hline Sorriso & Santos & BR-163, BR-364, Ferronorte (ALL) & 756 & 1.333 & - & 2,7 \\
\hline Sorriso & Santos & $\begin{array}{l}\text { BR-163, BR-364, MT-100, MS-306, SP- } \\
\text { B10 }\end{array}$ & 1.941 & - & - & -32 \\
\hline Sorriso & Santos & BR-163, BR-262, BR-374 & 2.090 & - & - & 3,8 \\
\hline Sorriso & Santos & BR-163, BR-267, SP-374 & 2.116 & - & - & 3,7 \\
\hline
\end{tabular}

\footnotetext{
${ }^{31}$ Condição media da rota: Para cada rota, calculou-se a média das condições mapeadas pela CNT a cada $10 \mathrm{~km}$ de rodovia, assumindo valores de 1 a 5 , respectivamente, para rodovias classificadas de péssima a ótima.

${ }^{32}$ A condição da rota que utiliza a BR-364 e MT-100 não foi calculada por indisponibilidade de informações.
} 
A condição desse corredor de exportações é entre ruim e regular no MT; regular no MS e ótima em SP. As rotas que utilizam a BR-267 e BR-262 têm condição média de rodovia 3,7 e 3,8, respectivamente.

A rota ferroviária apresenta boas condições nos $1.165 \mathrm{~km}$ do Alto Araguaia (MT) até Campinas (SP), com velocidade média de $50 \mathrm{~km} / \mathrm{h}$. No trecho de Jundiaí a Santos, ela cai drasticamente chegando a $16 \mathrm{~km} / \mathrm{h}$, resultado das dificuldades enfrentadas para cruzar a cidade de São Paulo, como, por exemplo, a invasão da faixa de domínio. Como padrão de comparação, a menor velocidade média das ferrovias norte-americanas é de $32 \mathrm{~km} / \mathrm{h}^{33}$.

- Corredor de Exportação Sorriso (MT) - Paranaguá (PR)

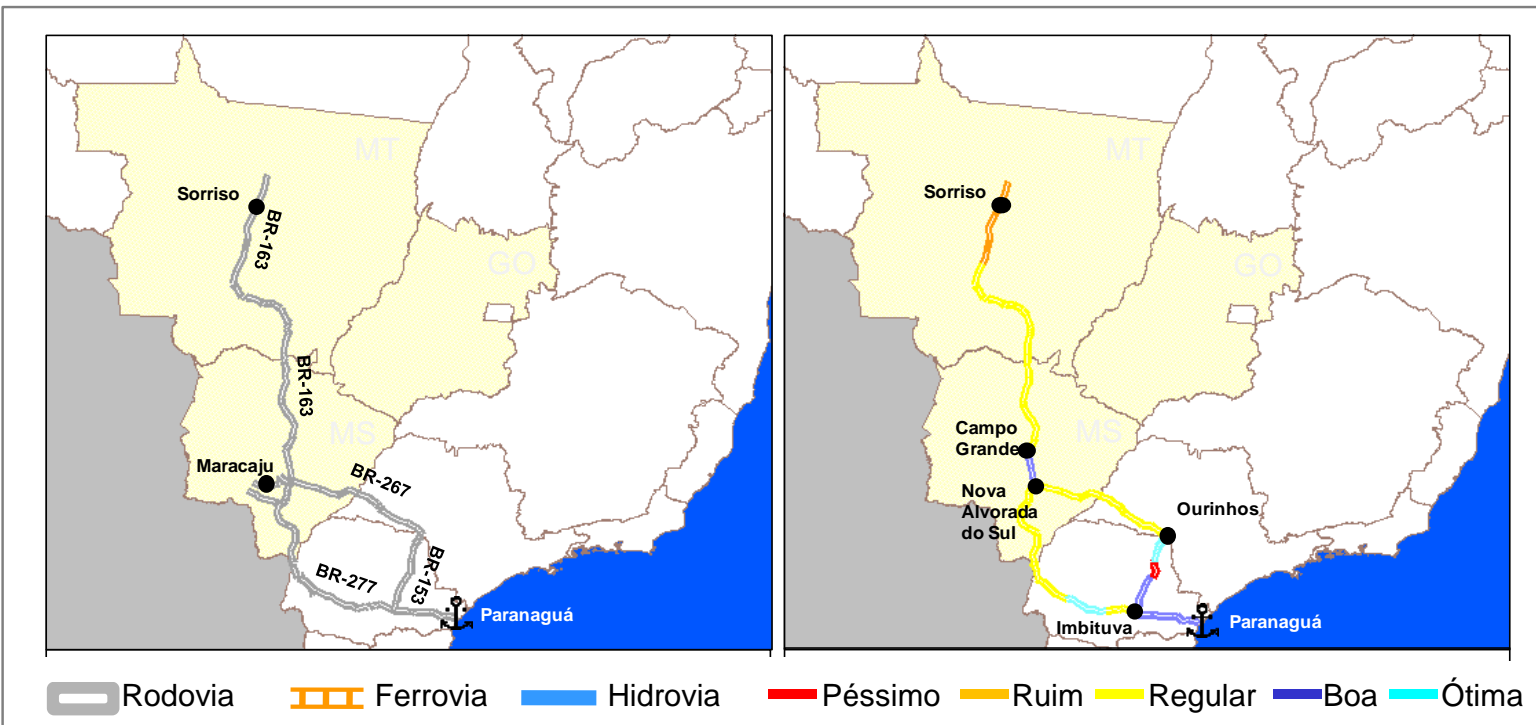

Figura 11: Mapeamento e condições do corredor de exportação Sorriso - Paranaguá. Fonte: elaboração autor

O corredor Sorriso - Paranaguá possui duas rotas que cruzam o MS na direção longitudinal, ambas pela BR-163, tendo como opções até o porto de Paranaguá a

${ }^{33}$ Association of American Railroads 
BR-277 ou a BR-267 mais a BR-153. As cargas da região de Sorriso, sul do MT e MS são potencialmente captadas por essas rotas. A distância de Sorriso até o porto é de $2.100 \mathrm{~km}$, aproximadamente, e de Maracaju até o porto é de $1.100 \mathrm{~km}$ (Tabela 18).

Tabela 18: Detalhamento das rotas do corredor Sorriso - Paranaguá. Fonte de dados: CNT (2006) / elaboração: autor

\begin{tabular}{|c|c|c|c|c|c|c|}
\hline \multirow{2}{*}{ Origem } & \multirow{2}{*}{ Destino } & \multirow{2}{*}{ Vias utilizadas } & \multicolumn{3}{|c|}{ Distância } & \multirow{2}{*}{$\begin{array}{c}\text { Condição } \\
\text { média da } \\
\text { rota }\end{array}$} \\
\hline & & & Rodo & Ferro & Hidro & \\
\hline Sorriso & Paranaguá & BR-163, BR-267, BR-153, BR-277 & 2.017 & - & - & 3,4 \\
\hline Sorriso & Paranaguá & BR-163, BR-277 & 2.265 & - & - & 3,3 \\
\hline Maracaju & Paranaguá & BR-163, BR-267, BR-153, BR-277 & 1.165 & - & - & 3,7 \\
\hline Maracaju & Paranaguá & BR-163, BR-277 & 1.111 & - & - & 3,4 \\
\hline
\end{tabular}

A condição média das rotas desse corredor é 3,3, variando de ruim a regular no $M T$, regular no MS até as cidades de Imbituba (PR) e Ourinhos (SP). Dessas cidades até o porto de Paranaguá, a condição é boa.

- Corredor de Exportação Sorriso (MT)-Santarém (PA)

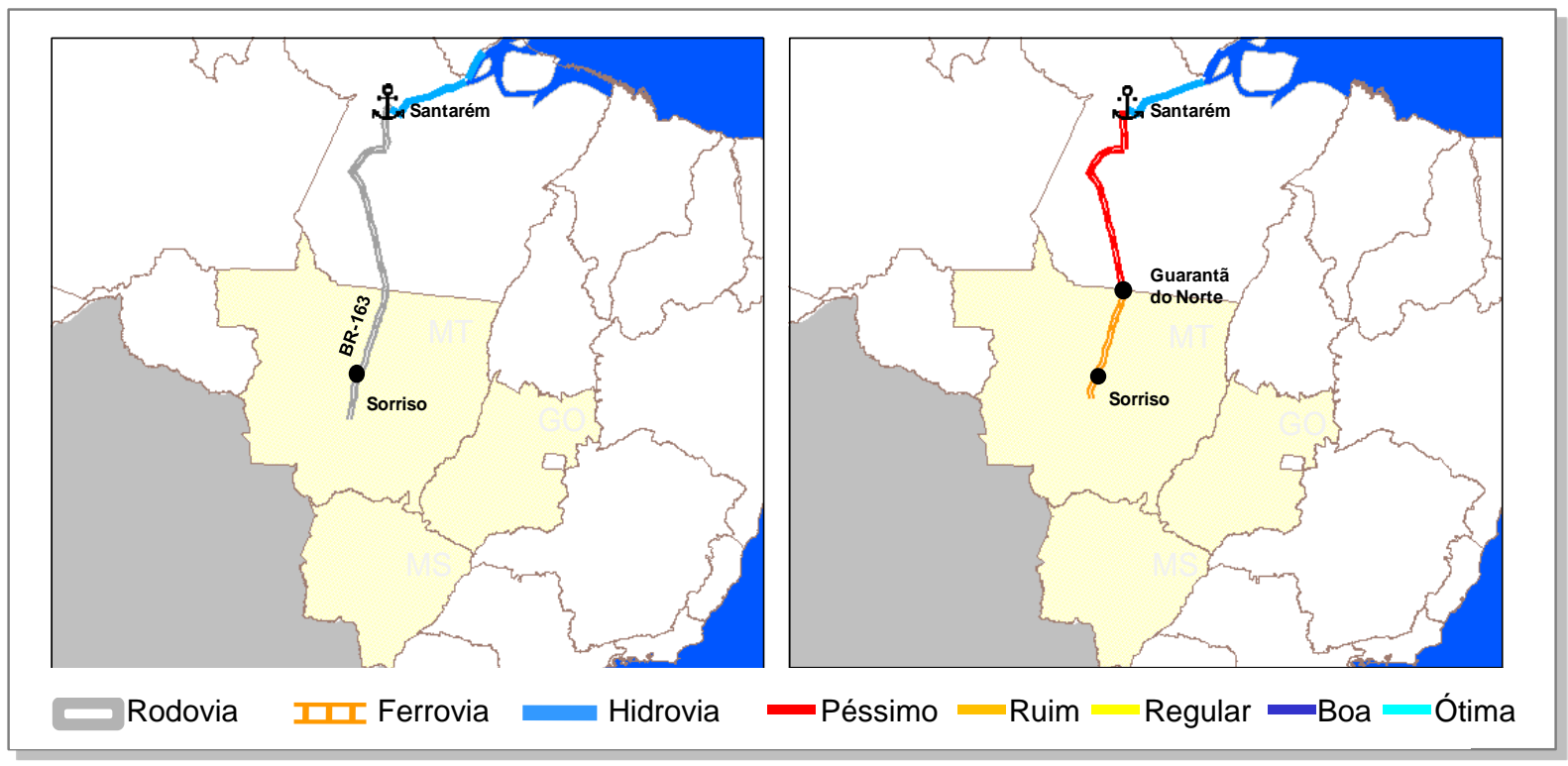

Figura 12: Mapeamento e condições do corredor de exportação Sorriso - Santarém. Fonte: elaboração autor 
O Porto de Santarém não exporta quantidade significativa da produção agrícola do MT, apesar de ser o porto mais próximo do norte desse estado. Um dos fatores que explicam essa ocorrência é a condição dos 1.350 km da BR-163, única opção para o transporte da produção do MT ao porto de Santarém (PA). A qualidade da BR-163 é ruim no Mato Grosso e péssima no Pará - onde não é pavimentada. A condição média da rota é 1,3 (Tabela 19).

Tabela 19: Detalhamento das rotas do corredor Sorriso - Santarém. Fonte de dados: CNT (2006) / elaboração: autor

\begin{tabular}{|l|l|l|l|c|c|c|}
\hline \multirow{2}{*}{ Origem } & Destino & Vias utilizadas & \multicolumn{3}{|c|}{ Distância } & $\begin{array}{c}\text { Condição média da } \\
\text { rota }\end{array}$ \\
\hline Sorriso & Santarém & BR-163 & Rodo & Ferro & Hidro & 1.343 \\
\hline
\end{tabular}

- Corredor de Exportação Campo Novo do Parecis (MT)-Itacoatiara (AM)

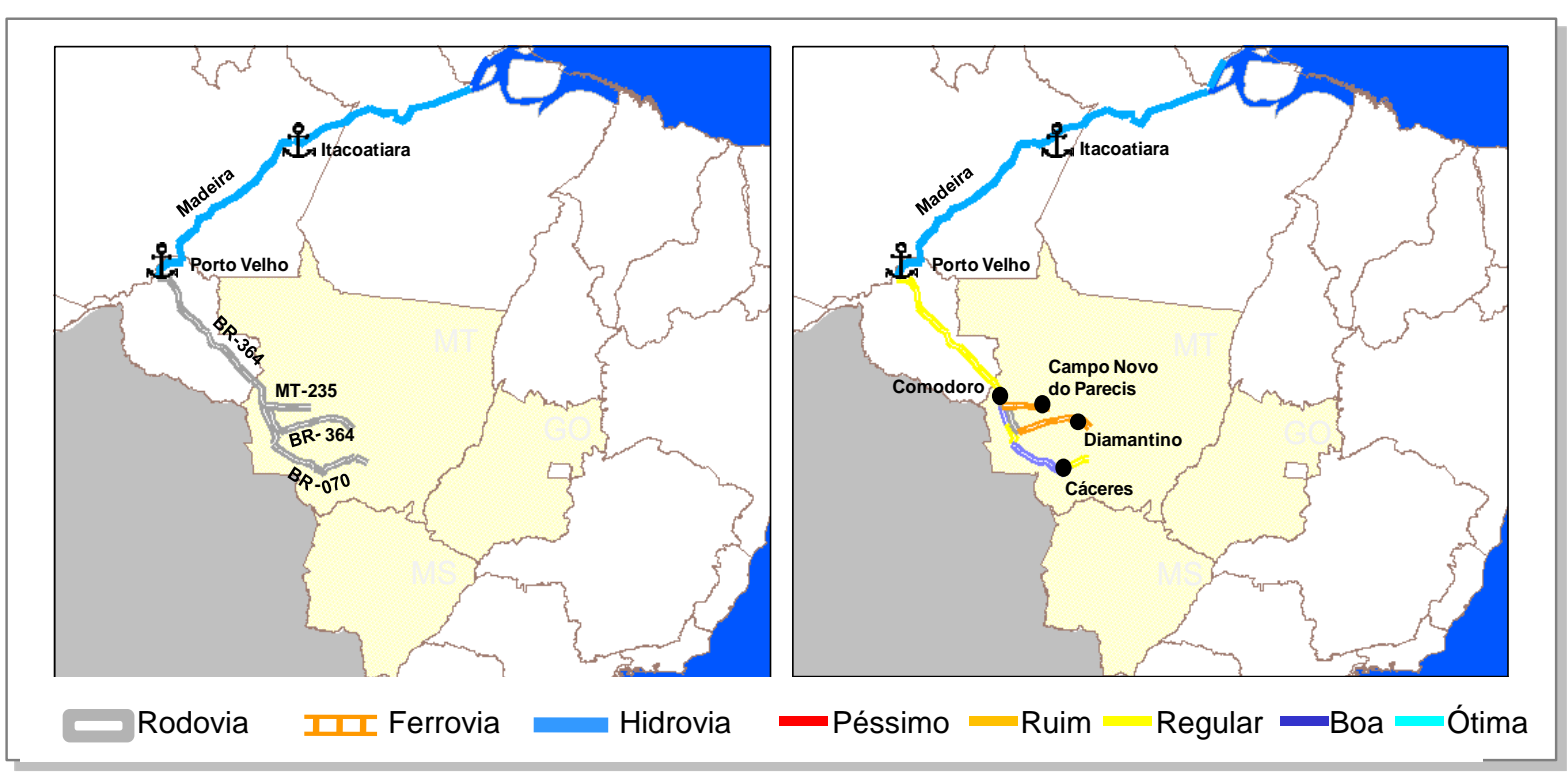

Figura 13: Mapeamento e condições do corredor de exportação Campo Novo do Parecis Itacoatiara. Fonte: elaboração autor

O corredor de exportações Campo Novo do Parecis - Itacoatiara conecta a região centro-sul do MT ao porto de Itacoatiara, que é capaz de receber navios de grande porte. Suas rotas são compostas obrigatoriamente por um trecho rodoviário (BR364) de Comodoro a Porto Velho e outro hidroviário (hidrovia do Madeira) de Porto Velho a Itacoatiara. Dependendo do ponto de origem existem três opções para 
chegar a Comodoro, a BR-364, BR-070 ou MT-235 (Tabela 20). De Campo Novo do Parecis a Itacoatiara, são 1.012 km de rodovia e 1.056 km de hidrovia.

Tabela 20: Detalhamento das rotas do corredor Campo Novo do Parecis - Itacoatiara. Fonte de dados: CNT (2006) / elaboração: autor

\begin{tabular}{|l|l|l|l|l|l|l|c|c|}
\hline \multicolumn{1}{|c|}{ Origem } & Destino & \multicolumn{2}{|c}{ Vias utilizadas } & \multicolumn{3}{c|}{ Distância } & $\begin{array}{c}\text { Condição } \\
\text { média da } \\
\text { rota }\end{array}$ \\
\hline Diamantino & Itacoatiara & BR-364, Hidrovia do Madeira & 1.277 & - & 1.056 & 2,8 \\
\hline $\begin{array}{l}\text { Campo Novo } \\
\text { do Parecis }\end{array}$ & Itacoatiara & $\begin{array}{l}\text { MT-235, } \\
\text { Madeira }\end{array}$ & BR-364, Hidrovia & do & 1.012 & - & 1.056 & 2,9 \\
\hline Cáceres & Itacoatiara & $\begin{array}{l}\text { BR-070, } \\
\text { Madeira }\end{array}$ & BR-364, Hidrovia & do & & & & \\
\hline
\end{tabular}

A ligação rodoviária Comodoro - Porto Velho, comum a todas as rotas, apresenta condição regular. Os trechos Diamantino - Comodoro e Campo Novo do Parecis Comodoro são ruins, enquanto no trecho Cáceres - Comodoro predomina a condição boa. A condição média das rotas desse corredor é aproximadamente 3.

O comboio-tipo da hidrovia do Madeira, de 16 chatas e com capacidade de 34.000 t, tem comprimento de $275 \mathrm{~m}$, boca de $44 \mathrm{~m}$ e calado de $2,5 \mathrm{~m}$ no período de águas mínimas. 
- Corredor de Exportação Maracaju (MS)-Santos (SP)

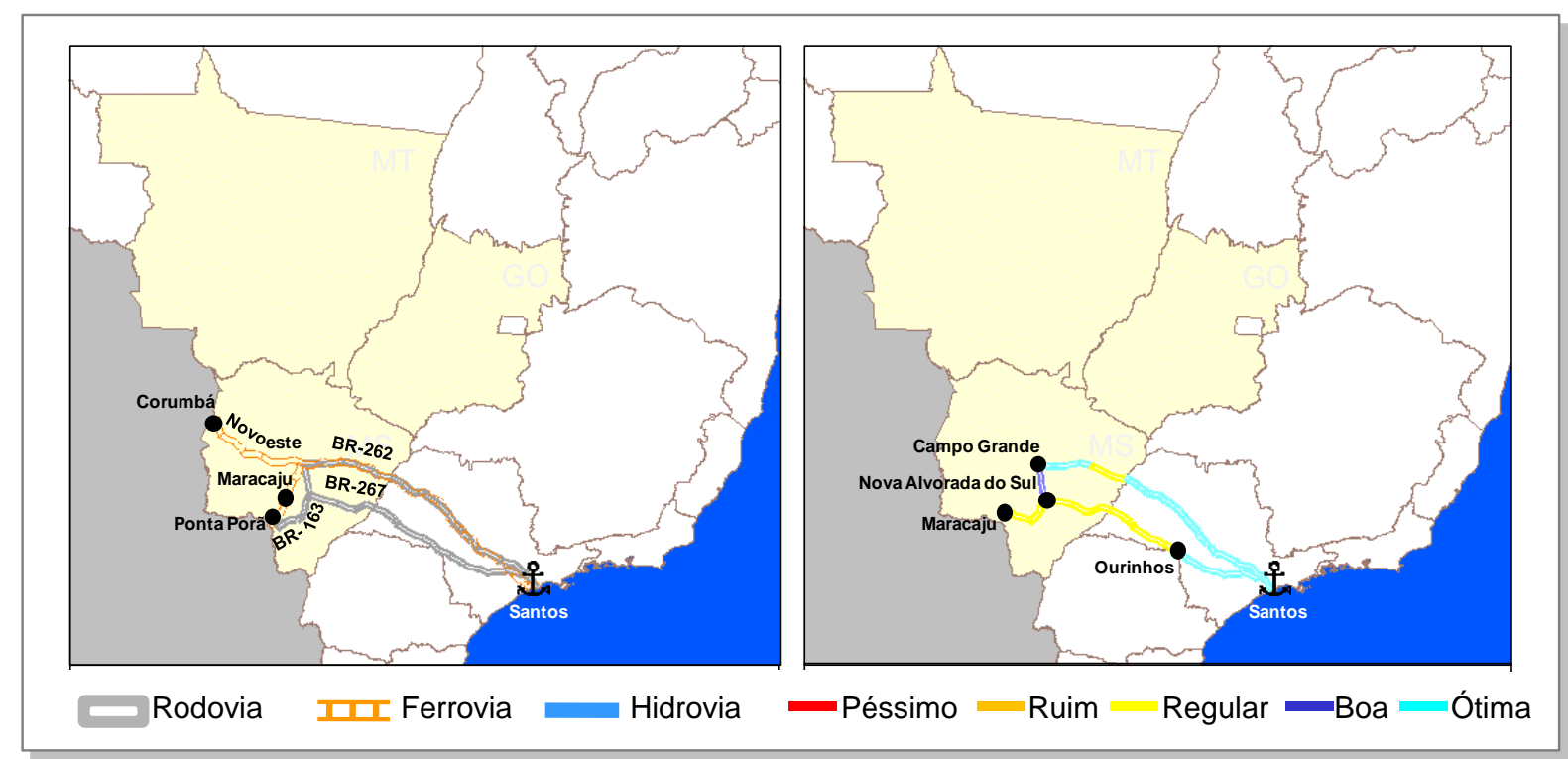

Figura 14: Mapeamento e condições do corredor de exportação Maracaju - Santos. Fonte: elaboração autor

Existem três rotas possíveis para o transporte de cargas do sul do Mato Grosso do Sul para Santos - duas apenas rodoviárias e uma ferroviária. As rotas rodoviárias valem-se da BR-262 e BR-267, também utilizadas no corredor de exportações Sorriso - Santos. A terceira opção é a ferrovia Novoeste (concessão da ALL), que passa por Maracaju. A extensão média das rotas rodoviárias é de aproximadamente $1.150 \mathrm{~km}$ e a da rota ferroviária é de $1.464 \mathrm{~km}$.

A rota Maracaju - Santos pela BR-262 apresenta condição ótima entre Campo Grande (MS) e Santos, com condição média é 4,3. Por outro lado, a rota que utiliza a BR-267 é regular de Maracaju (MS) a Ourinhos (SP) e ótima de Ourinhos até o porto, tendo condição média igual a 3,7 (Tabela 21). 
Tabela 21: Detalhamento das rotas do corredor Maracaju - Santos. Fonte de dados: CNT (2006) / elaboração: autor

\begin{tabular}{|l|l|l|r|r|r|c|}
\hline \multirow{2}{*}{ Origem } & \multirow{2}{*}{ Destino } & \multirow{2}{*}{ Vias utilizadas } & \multicolumn{3}{|c|}{ Distância } & $\begin{array}{c}\text { Condição média da } \\
\text { rota }\end{array}$ \\
\cline { 4 - 6 } & & & Rodo & Ferro & Hidro & \\
\hline Maracaju & Santos & BR-262, BR-374 & 1.235 & - & - & 4,3 \\
\hline Maracaju & Santos & BR-267, BR-374 & 1.086 & - & - & 3,6 \\
\hline Maracaju & Santos & BR-163, Novoeste & 10 & 1.464 & - & 3,2 \\
\hline
\end{tabular}

Apesar da concessão, a Novoeste ainda se encontra bastante deteriorada e apresenta baixa produtividade. A velocidade média dos trens é de $13 \mathrm{~km} / \mathrm{h}$ - valor muito baixo quando comparado com os $32 \mathrm{~km} / \mathrm{h}$ atingidos pela CSX Transportation, empresa norte-americana que tem a menor velocidade média dentre as maiores empresas de transporte ferroviário do EUA.

- Corredor de Exportação Sul de Goiás-Santos (SP)

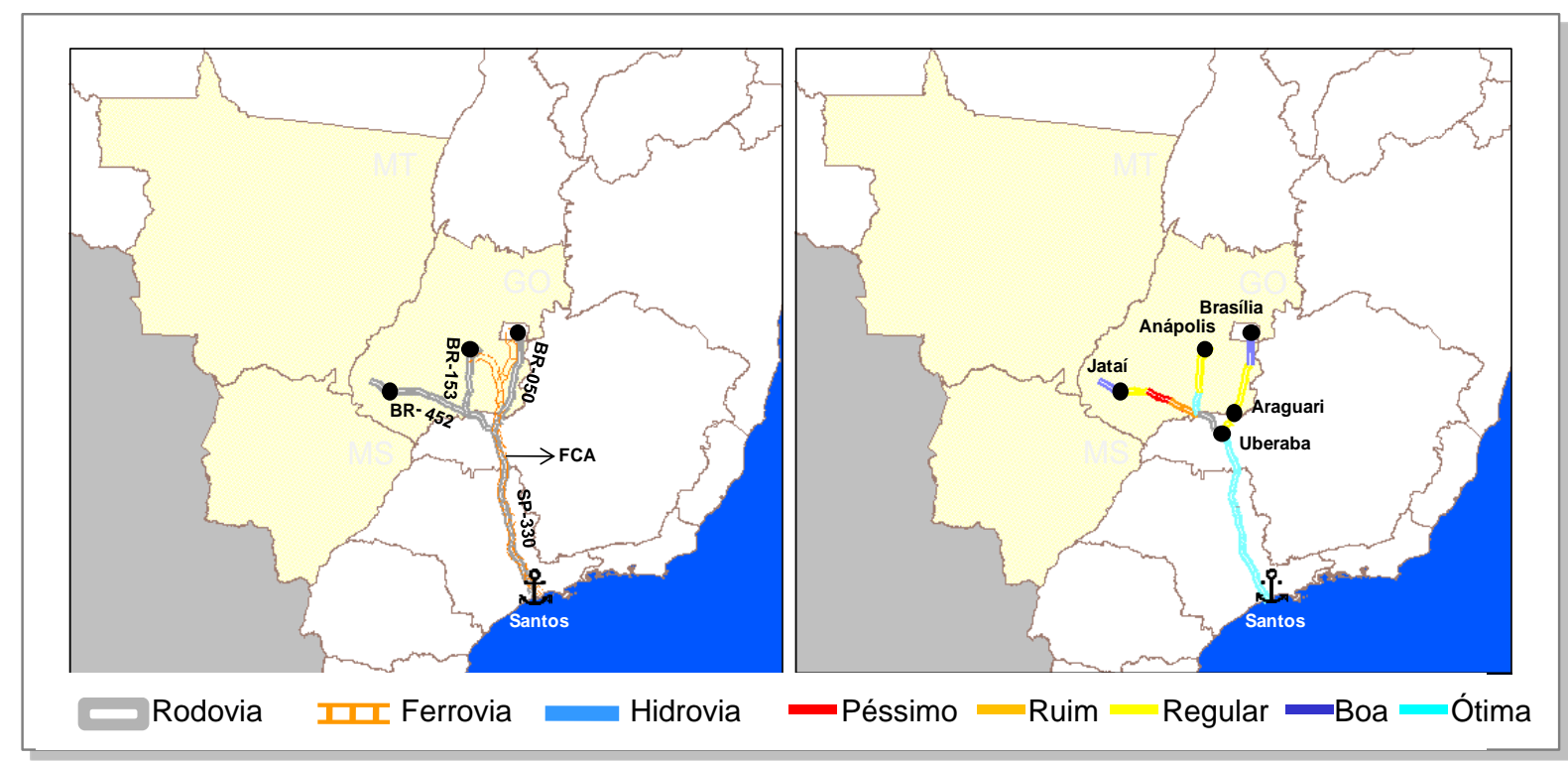

Figura 15: Mapeamento e condições do corredor de exportação Sul de Goiás-Santos. Fonte: elaboração autor

As opções de escoamento do sul goiano com destino a Santos são basicamente duas: a Ferrovia Centro-Atlântica (FCA) e a rodovia SP-330. A FCA apresenta uma pequena ramificação em Goiás, tendo terminais em Anápolis e Brasília, distando aproximadamente $1.300 \mathrm{~km}$ do porto. A SP-330, por sua vez, pode ser acessada a partir de três origens: Anápolis (BR-153), Brasília (BR-050) e Jataí (BR-452), sendo 
esta última a região de maior produção no estado. Até o porto, a distância por rodovias gira em torno de $1.100 \mathrm{~km}$ e, por ferrovias, $1.300 \mathrm{~km}$ (Tabela 22).

Tabela 22: Detalhamento das rotas do corredor sul de Goiás-Santos. Fonte de dados: CNT (2006) / elaboração: autor

\begin{tabular}{|l|l|l|c|c|c|c|}
\hline Origem & Destino & \multicolumn{1}{|c}{ Vias utilizadas } & \multicolumn{2}{c|}{ Distância } & $\begin{array}{c}\text { Condição média da } \\
\text { rota }\end{array}$ \\
\hline Jataí & Santos & BR-452, BR-050, SP-330 & 1.201 & - & - & 4,1 \\
\hline Anápolis & Santos & BR-153, BR-050, SP-330 & 1.058 & - & - & 4,4 \\
\hline Brasília & Santos & BR-050, SP-330 & 1.080 & - & - & 4,4 \\
\hline Anápolis & Santos & FCA & - & 1.282 & - & - \\
\hline Brasília & Santos & FCA & - & 1.353 & - & - \\
\hline
\end{tabular}

Os 560 km que unem Uberaba (MG) a Santos se destacam pela sua ótima condição. Com isso, as condições médias das rotas rodoviárias são acima de 4.

Ao contrário da ótima qualidade rodoviária, as rotas ferroviárias não apresentam boas condições nesse corredor. A velocidade média dos trens é de $14 \mathrm{~km} / \mathrm{h}$, atingindo no trecho paulista - até o porto de Santos - 7,6 km/h, dificultando consideravelmente o transporte de cargas. 
- Corredor de Exportação Sul de Goiás-Vitória (ES)

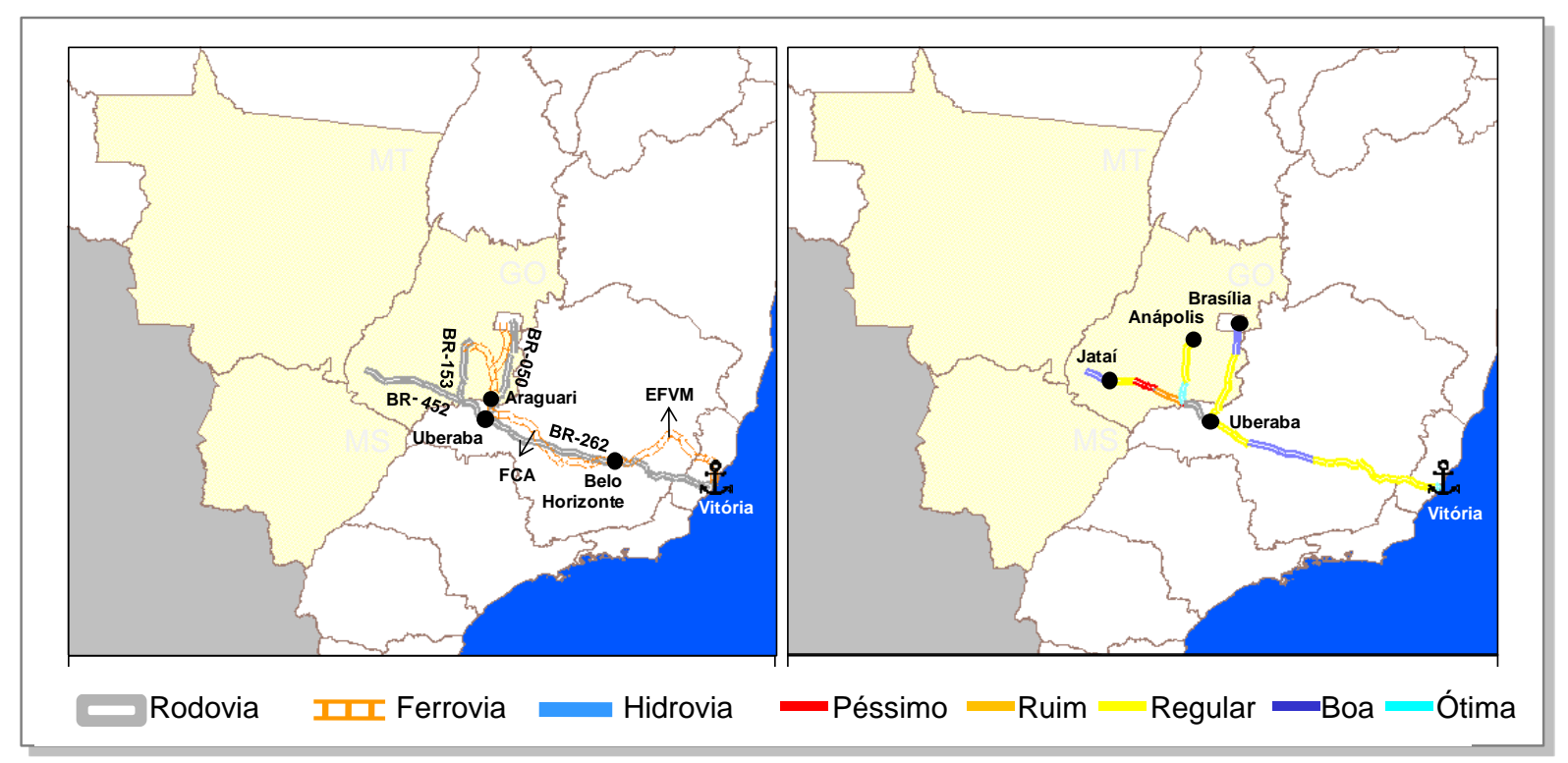

Figura 16: Mapeamento e condições do corredor de exportação Sul de Goiás-Vitória. Fonte: elaboração autor

Esse corredor tem grande importância para Goiás, já que por ele escoam $43 \%$ de suas exportações de soja, milho e açúcar. Existem duas opções de rota nesse corredor, uma rodoviária e outra ferroviária, ambas apresentando mais de uma origem.

As rotas rodoviárias originam-se em Jataí, Anápolis e Brasília, interceptando-se em Uberlândia, e seguindo até o porto de Vitória pela BR-262. A rota ferroviária parte de Anápolis e Brasília, sob concessão da FCA até Belo Horizonte, onde passa a ser concessão da Vale até Vitória (Estrada de Ferro Vitória Minas - EFVM). As rotas ferroviárias distam $2.000 \mathrm{~km}$ do porto, enquanto que as rodoviárias distam $1.450 \mathrm{~km}$. A condição média das três rotas é 3,4, com rodovias variando da condição regular a boa (Tabela 23). 
Tabela 23: Detalhamento das rotas do corredor sul de Goiás-Vitória. Fonte de dados: CNT (2006) / elaboração: autor

\begin{tabular}{|l|l|l|c|c|c|c|}
\hline \multirow{2}{*}{ Origem } & Destino & \multicolumn{1}{|c}{ Vias utilizadas } & \multicolumn{3}{|c|}{ Distância } & $\begin{array}{c}\text { Condição média } \\
\text { da rota }\end{array}$ \\
\cline { 4 - 7 } & & & Rodo & Ferro & Hidro & 3,3 \\
\hline Jataí & Vitória & BR-452, BR-262 & 1.466 & - & - & 3,4 \\
\hline Anápolis & Vitória & BR-153, BR-262 & 1.432 & - & - & 3,4 \\
\hline Brasília & Vitória & BR-050, BR-262 & 1.467 & - & - & - \\
\hline Anápolis & Vitória & FCA & - & 1.989 & - & - \\
\hline Brasília & Vitória & FCA & - & 2.060 & - & - \\
\hline
\end{tabular}

$\mathrm{Na}$ rota ferroviária, o trecho goiano apesar de seu traçado ser favorecido pela topografia plana, não apresenta velocidade média alta (em torno de $20 \mathrm{~km} / \mathrm{h}$ ). trecho entre Araguari (MG) e Belo Horizonte (MG) é crítico, pois apresenta terreno acidentado, sendo necessário transpor serras de traçado sinuoso e rampas de inclinação acentuada.

Existem também muitos cruzamentos de nível (interseção entre linha férrea e rodovias) e situações de adensamento populacional próxima à linha férrea na região metropolitana de Belo Horizonte, que obrigam a redução de velocidade. Em contrapartida, de Belo Horizonte a Vitória utiliza-se a EFVM, que é duplicada e apresenta bom traçado e sinalização. A velocidade média é de $60 \mathrm{~km} / \mathrm{h}$, a mais alta no Brasil.

A listagem das rotas aqui apresentados indica as principais vias de escoamento da produção agrícola da região $\mathrm{CO}$. É evidente que podem existir outras rotas de menor importância não mapeadas, contudo isso não afeta o desenvolvimento do presente trabalho. 


\subsubsection{Necessidades e Opções de desenvolvimento}

A precariedade da infraestrutura de transporte do CO não é recente. Como apresentado no item 3.2.2, não existem opções de escoamento para todas as direções e nos três estados a qualidade das vias é muito baixa. Essa constatação é corroborada por constantes relatos realizados principalmente por usuários.

Após uma série de alertas e com a situação chegando ao limite, o governo incluiu em seus planos e programas diversas obras com foco na região. Essas obras quando implantadas auxiliarão na criação de novos vetores logísticos de escoamento, melhorando, em última instância, a condição dos produtos brasileiros exportados.

A criação de rotas multimodais com a inclusão de hidrovias, quando possível, deveria figurar entre novas obras, pois resultam em menores custos para o transporte de granéis sólidos. Das rotas descritas no item anterior apenas 18\% são multimodais e menos de $10 \%$ usam hidrovias.

As obras constantes no PNLT e PAC que afetam a região são descrita a seguir.

\section{PNLT no CO}

Os investimentos indicados pelo PNLT referentes ao transporte de cargas do CentroOeste são:

- Implantação da Hidrovia Teles Pires, ligando a região de Sorriso (MT) ao porto de Santarém (PA);

- Construção e pavimentação da rodovia MT-235, unindo Campo Novo do Parecis (MT), Sapezal (MT) e Comodoro (MT) à BR-163, BR-158, Hidrovia Araguaia-Tocantins e ramal ferroviário de Ribeirão Cascalheira (MT);

- Dragagem do rio Tocantins e do rio das Mortes e construção da eclusa de Tucuruí (PA), unindo o leste do Mato Grosso a Belém (PA);

- Qualificação do rio Tocantins e construção das eclusas de Tucuruí (PA), Lajeado (TO) e Serra Quebrada (TO); 
- Pavimentação e recuperação da rodovia MT-100 e BR-158 ligando o leste do Mato Grosso à Marabá (PA), onde a carga será transportada pela Hidrovia Tocantins-Araguaia;

- Construção da ferrovia Ribeirão Cascalheira (MT) e Ferrovia Norte-Sul, permitindo o transporte até o porto de Itaqui (MA) usando a Estrada de Ferro Carajás;

- Construção do trecho da Ferrovia Norte-Sul que ligará Açailândia (MA) ao porto de Belém (PA). Alternativa ao porto de Itaqui (MA);

- Remodelação da ferrovia Novoeste de Corumbá (MT) a Santos (SP).

Os detalhes de cada agrupamento se encontram na Tabela 39 no anexo 7.2.

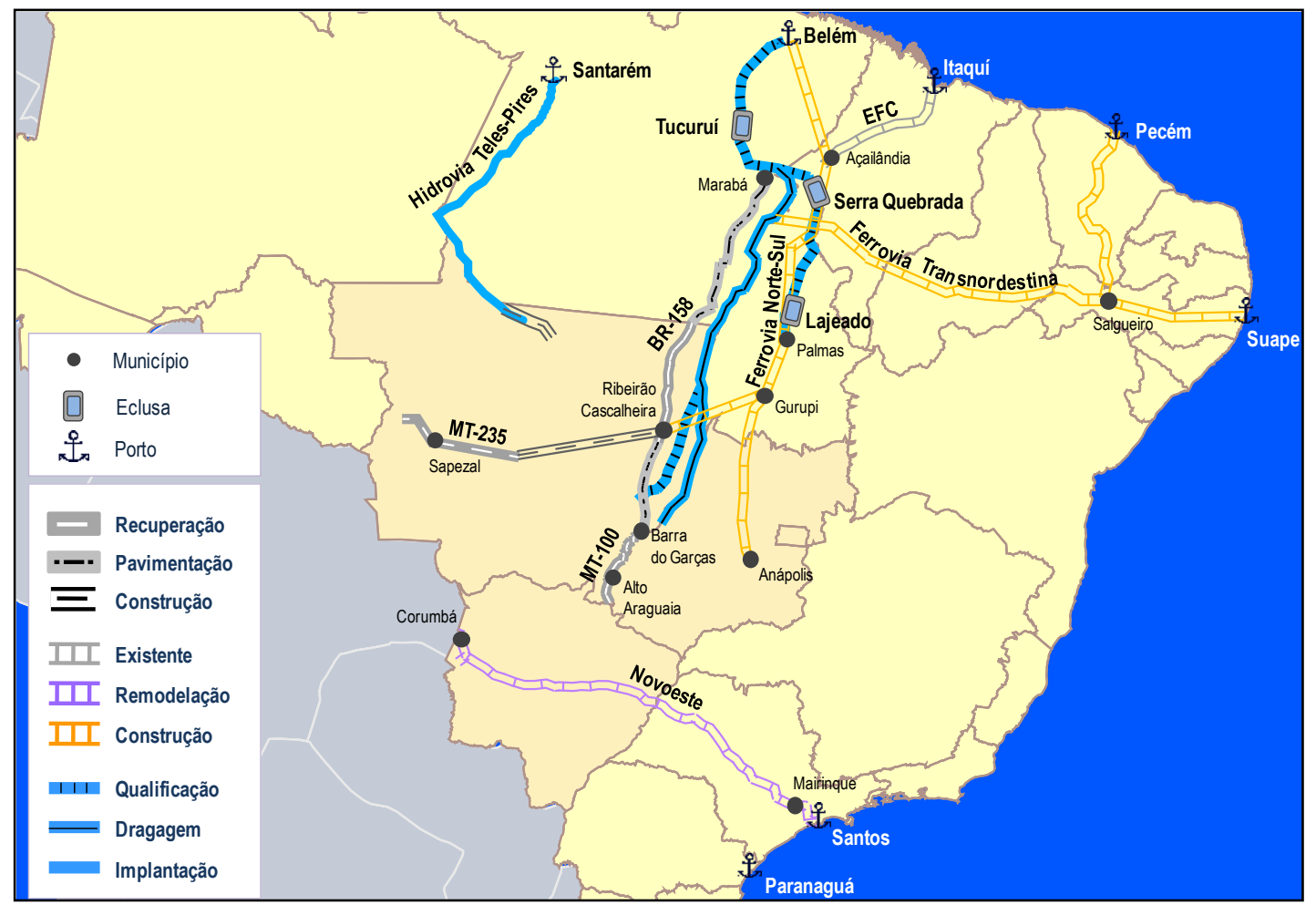

Figura 17: Mapeamento dos investimentos do PNLT com foco no CO. Fonte: CEGN (2010)

\section{PAC no CO}

Os investimentos em infraestrutura de transporte para o Centro-Oeste ${ }^{34}$, expostos no PAC 1, concentraram-se na recuperação ou pavimentação de rodovias e construção

\footnotetext{
${ }^{34}$ A região Centro-Oeste do Brasil será o foco das análises de infraestrutura de transportes. Sua importância será descrita no capítulo 3.2 (“A região Centro-Oeste: a")
} 
de ferrovias. Os investimentos rodoviários previstos no PAC 1 para a região CO são os seguintes:

- Pavimentação da BR-163 a partir da divisa do Mato Grosso (MT) com Pará até Santarém (PA);

- Construção e pavimentação da BR-242 de Sorriso (MT) a Ribeirão Cascalheira (MT);

- Construção e recuperação da BR-158 de Ribeirão Cascalheira (MT) até a divisa do Mato Grosso com o Pará;

- Duplicação da BR-364 de Rondonópolis a Posto Gil (MT), passando por Cuiabá (MT);

- Duplicação da BR-070 de Brasília (DF) a Águas Lindas (GO);

- Recuperação da BR-153 entre Aparecida de Goiânia (GO) e Itumbiara (GO);

- Duplicação da BR-060 de Brasília (DF) a Anápolis (GO);

- Construção de ponte no rio Paraná, ligando Brasilândia (MS) a Paulínia (SP).

Já os investimentos ferroviários e hidroviários previstos no referido programa consistem em:

- Construção de $260 \mathrm{~km}$ da Ferrovia Ferronorte do Alto Araguaia (MT) até Rondonópolis (MT);

- Construção da Ferrovia Norte-Sul ligando Santa Fé do Sul (SP) a Açailândia (MA), passando por Goiás e Tocantins;

- Construção da Ferrovia de Integração Centro-Oeste;

- Dragagem, derrocagem, sinalização e balizamento da hidrovia ParanáParaguai.

A Figura 18 ilustra esses investimentos. Os detalhes de cada investimento podem ser obtidos na Tabela 40, no anexo 7.2. 


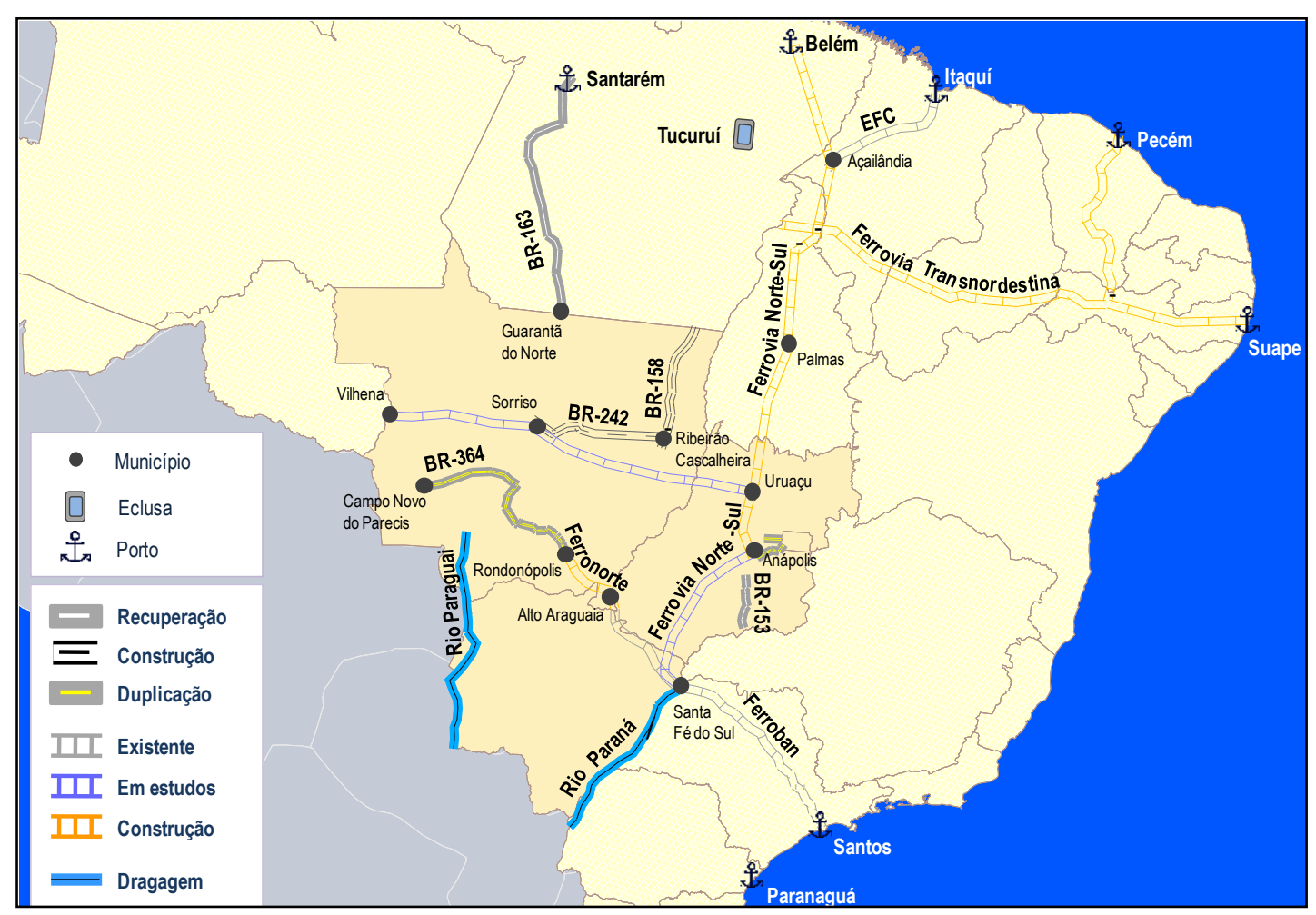

Figura 18: Mapeamento dos investimentos previstos no PAC 1 com foco no CO. Fonte: CEGN (2010)

A construção dessas obras melhoraria consideravelmente 0 escoamento da produção agrícola da região $\mathrm{CO}$, possibilitando, inclusive, o acesso a portos da região norte e nordeste, desafogando os portos de Santos e Paranaguá, por exemplo.

A implantação de todas as intervenções num curto intervalo de tempo seria o ideal, no entanto, a realidade é bem diferente, com apenas alguns investimentos sendo realizados, e a maioria ficando apenas nos planos.

Sendo assim, para que as principais obras não fiquem apenas no papel, é necessário que as opções de investimentos sejam priorizadas, sendo, imprescindível, portanto, um planejamento estratégico de transportes de fato. 
4 Planejamento Estratégico de Transportes: um exercício simplificado 


\subsection{Metodologia do exercício}

O exercício simplificado de planejamento desenvolvido nesta dissertação adota uma abordagem guiada por visão e por planejamento (May et al, 2005) e contempla simplificadamente 5 das 8 fases apontadas em ATC, 2006 (Figura 19), conforme citado no capítulo 2.1.

\begin{tabular}{|c|c|c|c|c|c|c|c|}
\hline $\begin{array}{l}\text { 1. Definição de } \\
\text { Objetivos } \\
\text { - Objetivos do } \\
\text { governo/sociais } \\
\text { - Objetivos do sistema de } \\
\text { transportes } \\
\text { - Indicadores de } \\
\text { desempenho e metas }\end{array}$ & $\begin{array}{l}\text { 2. Escolha de } \\
\text { políticas } \\
\text { - Definição de diretrizes } \\
\text { governamentais } \\
\text { - Decisões de políticas } \\
\text { de transportes }\end{array}$ & $\cdots$ & $\begin{array}{l}\text { 4. Iniciativas de } \\
\text { infraestrutura e } \\
\text { superestrutura } \\
\text { Oriundo de: } \\
\text { - Políticas e planejamento } \\
\text { do sistema } \\
\text { - Outras áreas do governo } \\
\text { - Setor privado } \\
\text { - Processo político }\end{array}$ & $\begin{array}{l}\text { 5. Avaliação das } \\
\text { iniciativas } \\
\text { - Teste de mérito } \\
\text { - Avaliação rápida } \\
\text { - Avaliação detalhada }\end{array}$ & $\begin{array}{l}\text { 6. Priorização de } \\
\text { iniciativas e } \\
\text { elaboração do } \\
\text { plano } \\
\text { - Identificação de } \\
\text { iniciativas prioritárias } \\
\text { - Desenvolvimento do } \\
\text { plano } \\
\text { - Decisão ministerial }\end{array}$ & $\cdots$ & $\cdots$ \\
\hline
\end{tabular}

Figura 19: Fases do planejamento do sistema de transporte. Fonte: Adaptado de ATC (2006)

Fases comtempladas:

- Fase 1: Definição dos objetivos estratégicos para o sistema de transportes em questão, e sua priorização;

- Fase 2: Definição da política para solução das questões de infraestrutura de escoamento da produção agrícola do CO;

- Fase 4: Levantamento das obras de infraestrutura de transporte relevantes para a região considerada;

- Fase 5: Avaliação destas obras através dos principais objetivos específicos; e

- Fase 6: Determinação das obras prioritárias.

Estas fases são desenvolvidas de forma simplificada. As cinco etapas estão distribuídas conforme ilustrado na Figura 20. 


\begin{tabular}{|c|c|c|c|c|}
\hline $\begin{array}{l}\text { Macro } \\
\text { planejamento }\end{array}$ & Contextualização & $\begin{array}{l}\text { Política de } \\
\text { desenvolvimento }\end{array}$ & $\begin{array}{l}\text { Priorização de } \\
\text { objetivos e dos } \\
\text { investimentos }\end{array}$ & Resultados \\
\hline $\begin{array}{l}\text { - Definição dos macro } \\
\text { objetivos }\end{array}$ & $\begin{array}{l}\text { Brasil: } \\
\text { - Histórico de } \\
\text { planejamento e } \\
\text { investimento no setor } \\
\text { de transportes } \\
\text { CO: } \\
\text { - Características e } \\
\text { necessidades } \\
\text { regionais (vocação } \\
\text { regional) } \\
\text { - Opções de } \\
\text { desenvolvimento da } \\
\text { infraestrutura de } \\
\text { transportes }\end{array}$ & $\begin{array}{l}\text { - Definição da política de } \\
\text { desenvolvimento a ser } \\
\text { seguida } \\
\text { - Definição dos objetivos } \\
\text { específicos para a } \\
\text { região }\end{array}$ & $\begin{array}{l}\text { Objetivos: } \\
\text { - Aplicação do Método } \\
\text { AHP nos diversos } \\
\text { objetivos identificados, } \\
\text { para seleção dos mais } \\
\text { importantes } \\
\text { Investimentos: } \\
\text { - Desenvolvimento de } \\
\text { indicadores } \\
\text { representativos dos } \\
\text { objetivos e priorização } \\
\text { dos investimentos }\end{array}$ & $\begin{array}{l}\text { - Comparação da } \\
\text { priorização de obras } \\
\text { com os programas do } \\
\text { governo } \\
\text { - Sugestões e } \\
\text { comentários }\end{array}$ \\
\hline
\end{tabular}

Figura 20: Metodologia do exercício simplificado apresentado. Fonte: elaboração autor

Na primeira fase serão definidos os objetivos estratégicos - macro - que refletem as prioridades estratégicas do governo, tanto em nível nacional como regional. Essa definição será realizada com base em temas usualmente abordados na literatura disponível sobre o assunto.

As características da região apresentadas no capítulo de "Contextualização", subitem 3.2, permitem afirmar que os sistemas de transporte que hoje servem a produção agrícola do Centro-Oeste brasileiro estão saturados e, portanto, políticas de incentivos ao processamento das commodities in loco, o aumento dos lotes médios, etc., seriam virtualmente inócuas. Assume-se, assim, que a política para solução das questões tratadas será a de expansão e melhoria da infraestrutura de transporte existente definindo a fase 2 estabelecida em ATC (2006).

Com os objetivos estratégicos definidos e focando na região, inicia-se à escolha dos objetivos específicos de interesse, separados nas categorias determinadas no nível macro.

A lista de objetivos específicos, provavelmente, será extensa e pode apresentar conflitos de interesse, por exemplo, entre as categorias ambientais e econômicas. A resolução desse problema se dará com o auxílio de uma ferramenta específica, o AHP, que permitirá a avaliação dos interesses de forma priorizada. 
O passo seguinte será relacionar indicadores a cada um dos principais objetivos. Os indicadores, que preferencialmente devem ser expressos em termos quantitativos, irão comparar as opções de desenvolvimento de transporte de cargas da região Centro-Oeste do Brasil (como custos de fretes e emissão de $\mathrm{CO}_{2}$, por exemplo).

A comparação através dos indicadores ${ }^{35}$ identificará, finalmente, quais são os investimentos prioritários para do desenvolvimento da infraestrutura de escoamento da produção agrícola da região.

${ }^{35}$ Essa comparação direta através dos indicadores configura-se como outra simplificação. Numa aplicação real todas as obras deveriam ser adicionadas no AHP e confrontadas com todos os objetivos de interesse, resultando na priorização completa. Fica, então, mais uma sugestão para novos trabalhos. 


\subsection{Objetivos do Planejamento Estratégico de transportes para a região específica}

\section{Objetivos Estratégicos}

Os três aspectos tratados na fase 1 do ATC (2006) - econômico, social e ambiental conforme apresentado no item 2.1, são os usualmente adotados como temas para delinear um planejamento estratégico, inclusive de transportes.

- Desenvolvimento econômico: inclui o aumento dos níveis de renda e de prosperidade, a criação de empregos, o fomento do desenvolvimento econômico, por meio do comércio e da exportação, entre outros;

- Desenvolvimento social: melhor distribuição de renda, o acesso adequado aos serviços de interesse público (também conhecido pelo termo "universalidade"), e a equidade (ou seja, o tratamento igual a todos os usuários do serviço; e

- Preservação ambiental: Grandes obras necessitam de detalhados estudos de impacto ambiental, tanto para a etapa de construção quanto para a fase de operação. Os objetivos ambientais englobam a proteção do meio-ambiente e da cultura local, e podem estar relacionadas ao desejo de viver em locais sem poluição, à preocupação com as gerações futuras e ao reconhecimento do valor do meio ambiente.

\section{Objetivos específicos de interesse}

Apesar da tomada de decisão ser muitas vezes subjetiva, uma série de critérios ou objetivos específicos pode ser empregada na priorização dos investimentos de infraestrutura, auxiliando o decisor na escolha.

Os objetivos específicos adotados neste trabalho, dentro dos macro-objetivos, são:

\section{Desenvolvimento Econômico:}

- Maximizar o retorno sobre investimento: qualquer investidor, seja ele privado ou público, quer o maior retorno possível para o seu investimento. No caso do investidor público em infraestrutura de transporte esse retorno pode ser calculado como a economia gerada ao país sobre o valor investido. 
- Redução dos custos totais de transportes: Novos projetos de infraestrutura tendem a buscar saídas para os portos, por exemplo, com menores distâncias que as atuais. Adicionalmente a diminuição das distâncias, existe a preocupação com outros custos operacionais, buscando alternativas multimodais que diminuam o custo total de transporte daquele corredor, que devem ser priorizadas.

- Maximizar a captação de cargas para exportação da região: o Brasil é um país tradicionalmente exportador de minérios e alimentos. O investimento em infraestrutura voltada para exportação aumenta a competitividade desse comércio, resultando em maior arrecadação para governo e iniciativa privada. Investimentos que possuem maior área de influência devem ser privilegiados sob esse critério;

Diminuição da participação das cargas do $\mathrm{CO}$ nos portos do Sul e Sudeste: os principais portos da região sul e sudeste do Brasil estão engargalados. Deste modo, obras que mudem o vetor de escoamento para outros portos, por exemplo, da região norte com menor ocupação, devem ser beneficiadas em relação as que mantem o vetor de escoamento atual, "desafogando" os portos como de Santos e de Paranaguá;

- Maior capacidade da via: Vias com maior capacidade tendem a transportar maiores volumes, melhorando o escoamento dos produtos da região em questão e, consequentemente, merecem destaque.

- Menor investimento por quilômetro de via: analisando somente sob o critério econômico, a comparação das alternativas de investimentos pode ser realizada através dos valores orçados das obras. No entanto, como as opções possuem diferentes comprimentos, uma comparação por quilômetro construído é mais justa, diferenciando inclusive os modais de transporte.

- Menor tempo de retorno do investimento (payback): É um critério de avaliação de risco e, portanto, os projetos mais atraentes são aqueles que permitam uma recuperação do capital investido em menor tempo.

- Menor desperdício no transporte de grãos: O transporte de cargas agrícolas sofre com a perda de quantidade significativa de produtos ao longo do trajeto até o destino final. Projetos que priorizam o modal de transporte que reduza o desperdício devem ser privilegiados sob esse critério. 


\section{Desenvolvimento Social:}

- Indução ao desenvolvimento de novas regiões: A construção de novas vias por lugares sem infraestrutura induz o desenvolvimento das cidades que circunscrevem as obras. Assim é razoável afirmar que obras com maior penetração em regiões precárias devem ser priorizadas.

- Maior integração regional: As intervenções que atravessam um maior número de regiões possibilita a maior captação de cargas e permite a integração entre as regiões.

- Aumentar padrão de segurança das vias: A atividade de transporte de cargas, principalmente rodoviário, gera alguns prejuízos sociais, como, por exemplo, elevado número de acidentes e mortes. Priorizar investimentos que distribuíam melhor os fluxos de transporte, diminuindo acidentes $\mathrm{e}$ consequentemente o número de mortes deve ser uma das preocupações dos planejadores.

\section{Preservação Ambiental:}

- Redução da emissão de gases do efeito estufa (por exemplo, $\mathrm{CO}_{2}$ ): $\mathrm{A}$ existência de diferentes modais de transporte possibilita a escolha, dada a existência na região, por um modal menos poluente. Investimentos que reconhecidamente emitam menor quantidade de gases (poluentes ou não, como o caso do $\mathrm{CO}_{2}$ ) precisam ser incentivados.

- Diminuição dos tempos de licenciamento: Uma das barreiras enfrentadas pelas grandes obras de infraestrutura é o processo de licenciamento ambiental. Empreendimentos com maior detalhamento dos impactos ambientais e indicação das suas medidas mitigatórias deve ser privilegiado em relação aos projetos mais básicos.

- Diminuição do consumo de combustível: Modais que possuam a menor relação de consumo de combustível (não-renovável) por carga transportada devem ser privilegiados no planejamento, garantindo a sustentabilidade do setor de transportes.

- Menor nível de devastação ambiental: A escolha por um modal de transporte e o traçado da via determinam a área a ser devastada. Quanto 
maior essa área, maior o prejuízo para o meio ambiente e sociedade como um todo. É razoável afirmar que os planejadores devem buscar a menor devastação, ou pela escolha do modal ou do traçado.

A lista de objetivos apresentada não é exaustiva, mas contém grande parte dos principais itens que precisam ser considerados no momento da tomada de decisão sobre uma obra de infraestrutura de transportes para uma dada região. Portanto, é imprescindível que façam parte do planejamento.

A priorização desses 15 itens sob os 3 critérios (desenvolvimento econômico; desenvolvimento social e preservação ambiental) via método AHP, criaria grande trabalho matemático, dispensável para o exercício simplificado apresentado nesta dissertação.

Portanto, aplicou-se, previamente, um filtro, reduzindo a 6 os objetivos a serem priorizados pelo AHP. São eles:

\section{Desenvolvimento Econômico:}

- Redução dos custos totais de transportes; e

- Maximizar o retorno sobre investimento.

\section{Desenvolvimento Social:}

- Redução da emissão de gases (por exemplo, $\mathrm{CO}_{2}$ ); e

- Diminuição dos tempos de licenciamento.

\section{Sustentabilidade:}

- Maior integração regional; e

- Indução ao desenvolvimento de novas regiões. 


\subsection{Priorização de critérios e objetivos}

O método AHP conforme descrito no item 2.1.1 permite a comparação e priorização dos objetivos estratégicos. Neste exercício, aplicou-se o método com a seguinte hierarquia:

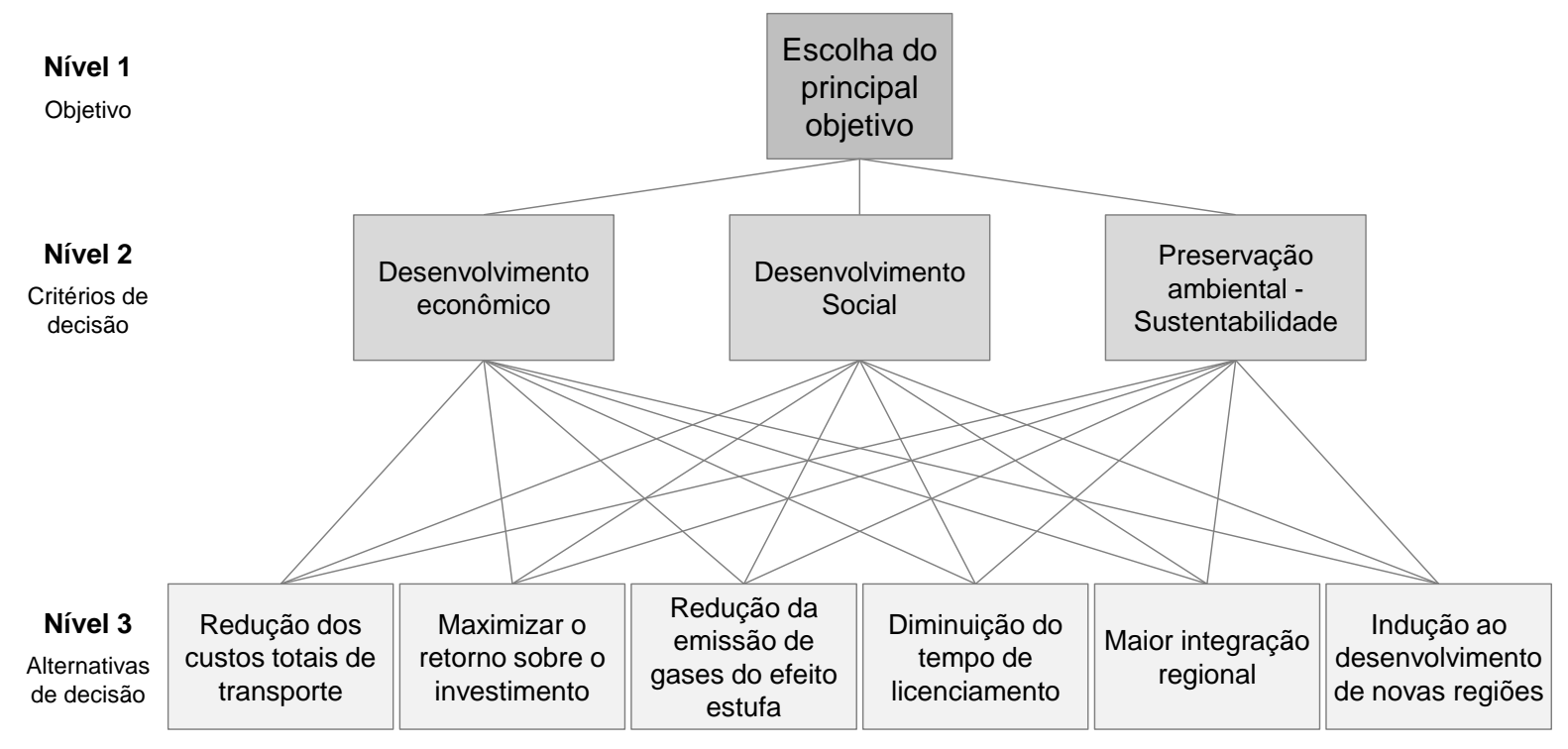

Figura 21: Hierarquia para priorização dos objetivos. Fonte: elaboração autor

Após a representação da hierarquia de decisão associada aos níveis de elementos inter-relacionados, inicia-se a comparação dos critérios aos pares.

O autor foi o responsável pelas notas atribuídas a cada um dos critérios. Focando nas melhorias necessárias no setor de transportes no país, o autor considerou que desenvolvimento econômico tem importância grande ou essencial ${ }^{36}$ sobre o desenvolvimento social e pequena sobre preservação ambiental, atribuindo notas 5 e 3, respectivamente, aos elementos desenvolvimento econômico-desenvolvimento social e desenvolvimento econômico-preservação ambiental.

\footnotetext{
${ }^{36}$ Definição baseada na escala de razão (Saaty, 1991) apresentada no item 2.1.1.
} 
Com relação ao elemento desenvolvimento social-preservação ambiental, o autor adotou o valor $1 / 3$, estabelecendo, portanto, uma importância pequena do segundo sobre o primeiro.

Os elementos da diagonal principal comparam os critérios com eles mesmos, portanto, possuem a mesma importância e são iguais a 1. Os elementos simétricos em relação a diagonal principal apresentam valores inversos.

Ao montar a matriz de comparação dos critérios de decisão, obtêm-se a Tabela 24.

Tabela 24: Comparação entre pares de critérios. Fonte: elaboração autor

\begin{tabular}{|l|c|c|c|}
\hline \multicolumn{1}{|c|}{ Critérios de julgamento } & $\begin{array}{c}\text { Desenvolvimento } \\
\text { econômico }\end{array}$ & $\begin{array}{c}\text { Desenvolvimento } \\
\text { social }\end{array}$ & $\begin{array}{c}\text { Preservação } \\
\text { ambiental }\end{array}$ \\
\hline $\begin{array}{l}\text { Desenvolvimento } \\
\text { econômico }\end{array}$ & 1 & 5 & 3 \\
\hline Desenvolvimento social & $1 / 5$ & 1 & $1 / 3$ \\
\hline Preservação ambiental & $1 / 3$ & 3 & 1 \\
\hline
\end{tabular}

Para interpretar e dar os pesos relativos a cada critério é necessário normalizar a matriz comparativa. A normalização é feita pela divisão entre cada elemento da tabela pela soma dos elementos da mesma coluna. A coluna de prioridade relativa é calculada, aproximadamente, com a média dos elementos da linha (Tabela 25).

Tabela 25: Prioridade relativa da seleção dos objetivos. Fonte: elaboração autor

\begin{tabular}{|l|c|c|c|c|}
\hline Critérios de julgamento & $\begin{array}{c}\text { Desenvolvimento } \\
\text { econômico }\end{array}$ & $\begin{array}{c}\text { Desenvolvimento } \\
\text { social }\end{array}$ & $\begin{array}{c}\text { Preservação } \\
\text { ambiental }\end{array}$ & $\begin{array}{c}\text { Prioridade } \\
\text { relativa (w) }\end{array}$ \\
\hline $\begin{array}{l}\text { Desenvolvimento } \\
\text { econômico }\end{array}$ & $1 /(1+1 / 5+1 / 3)=0,65$ & 0,56 & 0,69 & $\mathbf{0 , 6 3}$ \\
\hline Desenvolvimento social & 0,13 & 0,11 & 0,08 & $\mathbf{0 , 1 1}$ \\
\hline Preservação ambiental & 0,22 & 0,33 & 0,23 & $\mathbf{0 , 2 6}$ \\
\hline
\end{tabular}

O próximo passo é a verificação de consistência dos valores atribuídos. A estimativa do quociente de consistência é iniciada com o cálculo do vetor-soma ponderado (S), que é obtido pela multiplicação entre a matriz (A) comparativa original (Tabela 24) e o vetor-coluna $(\mathbf{w})$ de prioridade relativa (Tabela 25$)$. 


$$
\mathrm{S}=\mathrm{A} * \mathrm{w}=\left[\begin{array}{ccc}
1 & 5 & 3 \\
1 / 5 & 1 & 1 / 3 \\
1 / 3 & 3 & 1
\end{array}\right] *\left[\begin{array}{l}
0,63 \\
0,11 \\
0,26
\end{array}\right]=\left[\begin{array}{c}
1,95 \\
0,32 \\
0,79
\end{array}\right]
$$

O vetor de consistência é definido dividindo-se cada uma das linhas do vetor-soma ponderado $\mathbf{S}$ por cada uma das linhas do vetor prioridade relativa $\mathbf{w}$, resultando no vetor c.

$$
c=\left[\begin{array}{l}
1,95 / 0,63 \\
0,32 / 0,11 \\
0,79 / 0,26
\end{array}\right]=\left[\begin{array}{l}
3,071 \\
3,011 \\
3,032
\end{array}\right]
$$

A consistência média ( $\lambda$ máx) é calculada como a média dos elementos do vetor consistência c, sendo igual:

$$
\lambda \operatorname{máx}=\frac{(3,071+3,011+3,032)}{3}=3,038
$$

O índice de consistência, como apresentado no item 2.1.1, é calculado através:

$$
I C=\frac{\lambda \text { máx }-n}{n-1}=\frac{3,038-3}{3-1}=0,019
$$

Finalizando, calcula-se o quociente de consistência:

$$
Q C=\frac{\mathrm{IC}}{I C A}=\frac{0,019}{0,52}=0,04
$$

Onde ICA, para $n=3$ é retirado da Tabela 26 . 
Tabela 26: ICAs em função da ordem da matriz. Fonte: Colin (2007)

\begin{tabular}{|c|c|c|c|c|c|c|c|c|c|c|}
\hline$n$ & 1 & 2 & 3 & 4 & 5 & 6 & 7 & 8 & 9 & 10 \\
\hline ICA & 0 & 0 & 0,52 & 0,89 & 1,11 & 1,25 & 1,35 & 1,40 & 1,45 & 1,49 \\
\hline
\end{tabular}

Como $Q C \leq 0,1$, as notas atribuídas podem ser consideradas consistentes.

O próximo passo é a criação das matrizes de comparação para cada uma das alternativas de decisão do nível 3 (Figura 21) com relação aos critérios do nível 2 com cálculo do quociente de consistência para cada uma.

As Tabela 27, Tabela 28 e Tabela 29 do nível 3 foram construídas seguindo a mesma sequência da apresentada para o nível 2. Os valores foram atribuídos, novamente, pelo autor.

Tabela 27: Comparação entre pares e prioridades nível 3 - Desenvolvimento econômico.

Fonte: elaboração autor

\begin{tabular}{|c|c|c|c|c|c|c|c|}
\hline $\begin{array}{l}\text { Desenv. } \\
\text { Econômico }\end{array}$ & $\begin{array}{l}\text { Maximizar o } \\
\text { retorno sobre o } \\
\text { investimento }\end{array}$ & $\begin{array}{l}\text { Redução dos } \\
\text { custos totais de } \\
\text { transporte }\end{array}$ & $\begin{array}{l}\text { Redução da } \\
\text { emissão de } \\
\text { gases do } \\
\text { efeito estufa }\end{array}$ & $\begin{array}{c}\text { Diminuição } \\
\text { do tempo de } \\
\text { licenciamento }\end{array}$ & $\begin{array}{l}\text { Maior } \\
\text { integração } \\
\text { regional }\end{array}$ & $\begin{array}{c}\text { Maior indução } \\
\text { ao } \\
\text { desenvolvimento } \\
\text { de regiões }\end{array}$ & $\begin{array}{c}\text { Prioridade } \\
\text { relativa }\end{array}$ \\
\hline $\begin{array}{l}\text { Redução da } \\
\text { emissão de } \\
\text { gases do efeito } \\
\text { estufa }\end{array}$ & $1 / 9$ & $1 / 7$ & 1 & $1 / 5$ & $1 / 5$ & $1 / 5$ & 0,027 \\
\hline $\begin{array}{l}\text { Diminuição do } \\
\text { tempo de } \\
\text { licenciamento }\end{array}$ & $1 / 7$ & $1 / 5$ & 5 & 1 & 1 & $1 / 3$ & 0,075 \\
\hline \begin{tabular}{|l|} 
Maior indução \\
ao \\
desenvolvimento \\
de regiões \\
\end{tabular} & $1 / 2$ & $1 / 2$ & 5 & 3 & 3 & 1 & 0,176 \\
\hline
\end{tabular}


Tabela 28: Comparação entre pares e prioridades nível 3 - Desenvolvimento social. Fonte: elaboração autor

\begin{tabular}{|c|c|c|c|c|c|c|c|}
\hline Desenv. Social & $\begin{array}{l}\text { Maximizar o } \\
\text { retorno sobre o } \\
\text { investimento }\end{array}$ & $\begin{array}{l}\text { Redução dos } \\
\text { custos totais de } \\
\text { transporte }\end{array}$ & $\begin{array}{c}\text { Redução da } \\
\text { emissão de } \\
\text { gases do } \\
\text { efeito estufa }\end{array}$ & $\begin{array}{c}\text { Diminuição } \\
\text { do tempo de } \\
\text { licenciamento }\end{array}$ & $\begin{array}{l}\text { Maior } \\
\text { integração } \\
\text { regional }\end{array}$ & $\begin{array}{l}\text { Maior indução } \\
\text { ao } \\
\text { desenvolvimento } \\
\text { de regiões }\end{array}$ & $\begin{array}{c}\text { Prioridade } \\
\text { relativa }\end{array}$ \\
\hline $\begin{array}{l}\text { Redução da } \\
\text { emissão de } \\
\text { gases do efeito } \\
\text { estufa } \\
\end{array}$ & 3 & 3 & 1 & 5 & 1 & 3 & 0,304 \\
\hline $\begin{array}{l}\text { Diminuição do } \\
\text { tempo de } \\
\text { licenciamento }\end{array}$ & 1 & 1 & $1 / 5$ & 1 & $1 / 3$ & 1 & 0,085 \\
\hline $\begin{array}{l}\text { Maior indução } \\
\text { ao } \\
\text { desenvolvimento } \\
\text { de regiões }\end{array}$ & 5 & 5 & $1 / 3$ & 1 & 1 & 1 & 0,201 \\
\hline
\end{tabular}

Tabela 29: Comparação entre pares e prioridades nível 3 - Preservação ambiental. Fonte: elaboração autor

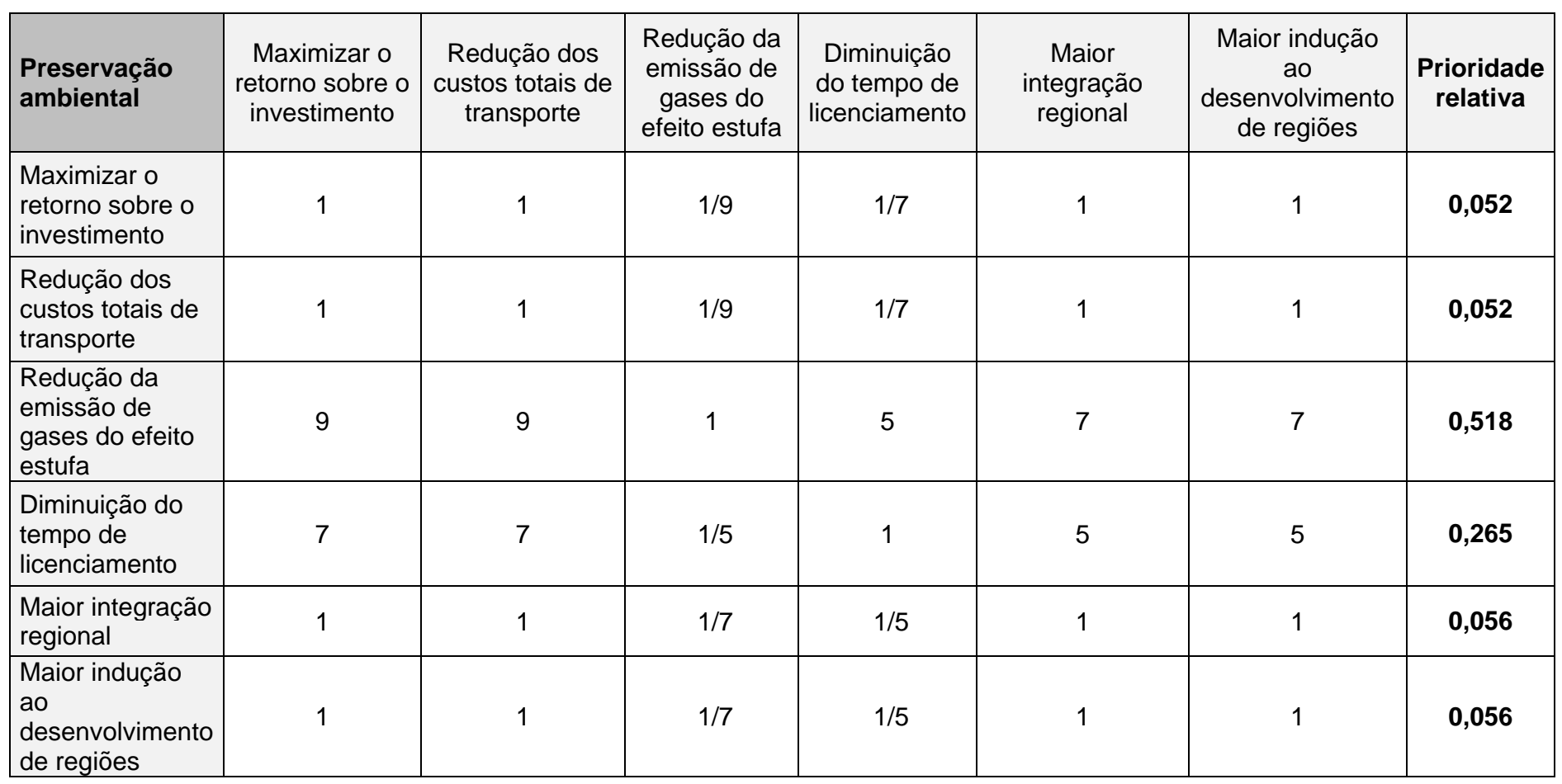


Como a construção das tabelas acima é subjetiva, calculou-se novamente o quociente de consistência para cada uma delas, resultando em 0,08, 0,07 e 0,04, respectivamente, indicando, portanto, consistência.

A matriz resultante de prioridade do nível 3 com relação ao nível 2 é apresentada resumida na Tabela 30.

Tabela 30: Matriz de prioridade do nível 3 com relação ao nível 2. Fonte: elaboração autor

\begin{tabular}{|c|c|c|c|c|}
\hline & \multirow[b]{2}{*}{$\begin{array}{l}\text { Prioridades relativas } \\
\text { agregadas }\end{array}$} & \multicolumn{3}{|c|}{ Critérios } \\
\hline & & 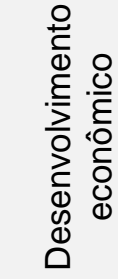 & 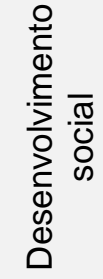 & 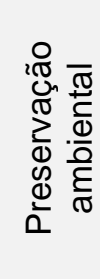 \\
\hline \multirow{6}{*}{ 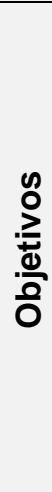 } & $\begin{array}{l}\text { Maximizar o retorno sobre o } \\
\text { investimento }\end{array}$ & 0,41 & 0,06 & 0,05 \\
\hline & $\begin{array}{l}\text { Redução dos custos totais } \\
\text { de transporte }\end{array}$ & 0,22 & 0,07 & 0,05 \\
\hline & $\begin{array}{l}\text { Redução da emissão de } \\
\text { gases do efeito estufa }\end{array}$ & 0,03 & 0,30 & 0,52 \\
\hline & $\begin{array}{l}\text { Diminuição do tempo de } \\
\text { licenciamento }\end{array}$ & 0,08 & 0,09 & 0,27 \\
\hline & Maior integração regional & 0,09 & 0,28 & 0,06 \\
\hline & $\begin{array}{l}\text { Maior indução ao } \\
\text { desenvolvimento de regiões }\end{array}$ & 0,18 & 0,20 & 0,06 \\
\hline
\end{tabular}

Para finalizar, realiza-se a agregação de prioridades, multiplicando a Tabela 30 pelo vetor-coluna (w) da Tabela 24, resultando na Tabela 31.

Tabela 31: Priorização de objetivos. Fonte: elaboração autor

\begin{tabular}{|l|r|}
\hline Objetivos & Prioridade \\
\hline $\begin{array}{l}\text { Maximizar o retorno sobre o } \\
\text { investimento }\end{array}$ & 0,277 \\
\hline $\begin{array}{l}\text { Redução da emissão de } \\
\text { gases do efeito estufa }\end{array}$ & 0,184 \\
\hline $\begin{array}{l}\text { Redução dos custos totais } \\
\text { de transporte }\end{array}$ & 0,162 \\
\hline $\begin{array}{l}\text { Maior indução ao } \\
\text { desenvolvimento de regiões }\end{array}$ & 0,148 \\
\hline $\begin{array}{l}\text { Diminuição do tempo de } \\
\text { licenciamento }\end{array}$ & 0,126 \\
\hline Maior integração regional & 0,103 \\
\hline
\end{tabular}


Portanto, a listagem das obras de infraestrutura do $\mathrm{CO}$ deve ser realizada através da maximização do retorno sobre o investimento. Essa priorização será realizada, simplificadamente, no item 4.4.

O segundo objetivo de maior importância, conforme a metodologia apresentada, é a redução da emissão de gases do efeito estufa, indicando a preocupação crescente com o meio ambiente. A redução dos custos totais de transporte completa a lista dos três principais objetivos a serem perseguidos na escolha das obras.

Ao contrário do apresentado por Kölbl, Niegl e Knoflacher (2008) nos exemplos das Tabela 6, Tabela 7 e Tabela 8 (capítulo 2.1) que mostravam excessiva preocupação com aspectos ambientais, o julgamento feito pelo autor no exercício desta dissertação, apesar de conter objetivos ambientais, resultou em maior preocupação com questões econômicas.

É razoável supor que, em alguns anos, com o aumento da necessidade de investimentos que garantam a sustentabilidade do planeta, a realização do mesmo exercício resulte na priorização de apenas objetivos ambientais, aproximando-se portanto dos resultados de Kölbl, Niegl e Knoflacher (2008), que aparentemente já vivem tal preocupação. 


\subsection{Avaliação comparativa das obras a luz da priorização dos objetivos adotados}

\subsubsection{Ganhos potenciais com novos corredores: maximização do retorno sobre o investimento}

Os investimentos necessários para realização das obras são vultosos. No entanto, cada nova rota, com menor distância, melhor qualidade e multimodalidade, gera economia de frete, não necessariamente voltada diretamente ao produtor ou transportador, mas para o sistema como um todo. A relação dessa economia com o investimento pode ser chamada de "retorno do investimento".

Em finanças, retorno sobre investimento, também chamado taxa de retorno ou simplesmente retorno, é a relação entre o dinheiro ganho ou perdido através de um investimento, e o montante investido.

O cálculo formal do retorno para o exercício em questão deveria ser realizado considerando a evolução da produção e da área plantada ano a ano, tempo de maturação do investimento com movimentação ao longo dos anos, projeção dos custos de fretes e receitas descontadas ao longo do tempo.

No entanto, como o exercício não precisa determinar com exatidão o retorno de cada investimento e sim analisar comparativamente as opções à luz de um indicador, a forma de cálculo da economia gerada foi realizada de forma simplificada.

O cálculo considerou a produção agrícola de apenas um ano, 2023, adotando, portanto o último ano do horizonte de tempo do PNLT, ano em que todas as obras deveriam estar concluídas segundo o plano. Os fretes atuais e futuros foram determinados a partir da mesma base, ou seja, valores vigentes entre 2007 e 2010, não fazendo uma projeção para 2023.

Com tais simplificações e com o objetivo de mensurar a economia gerada em cada corredor, criou-se um adimensional $R$ para comparar os diversos investimentos. $O R$ 
possui como variáveis de entrada a variação de frete - futuro com obras subtraído do atual -, volume de exportação potencialmente captado por cada rota em determinado ano e o investimento necessário.

O Ré calculado como:

$$
R=\frac{\Delta \mathrm{f} \times \mathrm{P}_{2023}}{\mathrm{I}}
$$

Onde:

$\Delta f$ : variação do frete obtida com a utilização de um novo corredor de exportação $[R \$ / t]$.

$P_{2023:}$ carga captada pelo corredor de exportação no ano de 2023 [toneladas].

I: valor investido no corredor $[\mathrm{R} \$]$.

As variáveis do $R$, variação de frete $(\Delta f)$ e sua carga potencial de cada corredor $\left(P_{2023}\right)$, serão calculadas nos próximos itens.

Vale ressaltar que o $R$ não considera a projeção do valor de frete, ou seja, utiliza a mesma curva - detalhada nos próximos itens - para os cálculos atuais e futuros, não considera o faseamento das obras com entrada em diferentes anos e não acumulando as "economias" ao longo dos anos. O $R$ verifica a economia gerada em apenas um ano, o ano de 2023.

\subsubsection{Cálculo de fretes rodoviários, ferroviários e hidroviários}

Os custos por quilometro para o transporte de uma tonelada de soja, por exemplo, é diferente para cada modal e influencia diretamente no frete cobrado. Caixeta Filho (2008) estimou que para distâncias superiores a $1.000 \mathrm{~km}$ o frete ferroviário e hidroviário por quilômetro deveria ser $60 \%$ e $68 \%$ inferiores ao rodoviário, respectivamente. No entanto, esta diferença não é verificada na prática, onde o frete ferroviário é prefixado como aproximadamente $90 \%$ do rodoviário ${ }^{37}$.

\footnotetext{
${ }^{37}$ Segundo contato com concessionárias ferroviárias. O valor cobrado é aproximadamente $90 \%$ do valor do segundo melhor preço.
} 
Em razão das incertezas quanto às estimativas apresentadas nas bases acessadas e da necessidade de determinação dos custos de frete, calculou-se os fretes médios para cada um dos modais. Nesse trabalho os valores base de fretes são tomados a mercado.

\section{Modal rodoviário}

Diversos estudos foram realizados com o objetivo de determinar os fatores formadores de custos de transporte rodoviários. Berger (1975) (apud Bartholomeu, 2006) afirma que a distância é um dos mais importantes, mas também destaca outras características que podem alterar os custos, tais como: qualidade das estradas, intensidade do trânsito, densidade da produção e produto transportado.

Segundo Correa Junior (2001) os valores de frete praticados no transporte de soja a granel com origem em MT, GO e PR durante as safras de 1998 a 2000 foram influenciados por fatores como: distância percorrida, existência de praças de pedágio, sazonalidade da demanda por transporte e condições das vias utilizadas.

Ao quantificar os impactos econômicos e ambientais decorrentes do estado de conservação das rodovias brasileiras, Bartholomeu (2006) conclui que rotas com diferentes condições de infraestrutura resultam em custos de viagem distintos, relacionados ao consumo e combustível, ao tempo de viagem e ao gasto com manutenção.

A distância percorrida é citada em todos os trabalhos acessados como o fator mais importante da determinação do frete. Sendo assim, apesar de vias em melhores condições de conservação resultar em maiores benefícios econômicos e ambientais, como os investimentos são comparados no longo prazo, é razoável assumir que a qualidade das vias esteja na classificação entre boa e ótima, não alterando significativamente os custos operacionais. Portanto, o único fator a ser considerado no calculo do frete é a distância.

Utilizou-se a base de dados do Sistema de Informação de Fretes (Sifreca) da Escola Superior de Agricultura "Luiz de Queiroz" (ESALQ-USP) para determinar uma curva representativa desses custos. A base de produtos adotada foi: soja, farelo de soja, 
milho e açúcar. Foram tomados centenas de pares frete versus distância (Gráfico $11)$.

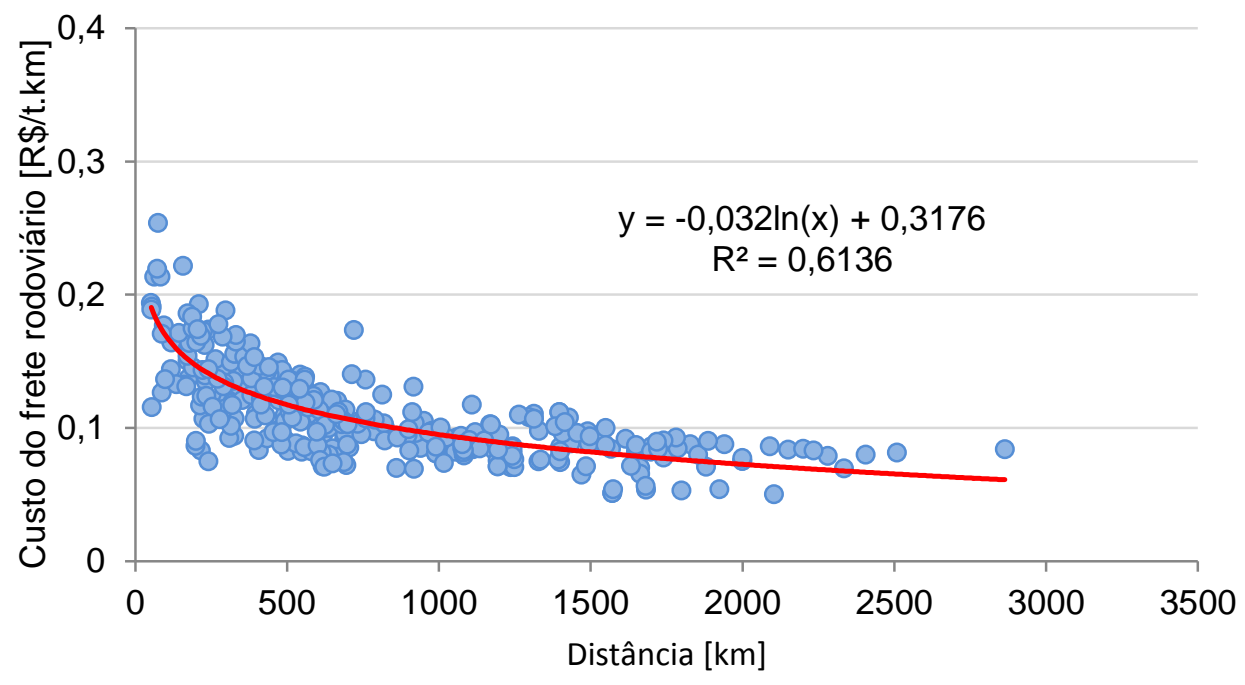

Gráfico 11: Curva de frete rodoviário (R\$/t.km). Fonte: elaboração autor

Do Gráfico 11, obteve-se a equação representativa para os fretes rodoviários $(F r)$ em função da distância $(d)$ :

$$
F_{r}=d *(-0,03 \ln (d)+0,317)
$$

Onde, $F_{r}$ é dado em $\mathrm{R} \$ / \mathrm{t}$.

O cálculo do frete para diversas origens e destinos será determinante na distribuição das cargas pelos portos brasileiros, através de suas áreas de influência (4.4.1.2).

\section{Modal ferroviário}

O frete ferroviário foi determinado como a média das tarifas atuais cobradas pela Ferrovia Centro-Atlântica (FCA), MRS Logística S.A., ALL, Estrada de Ferro Carajás e Estrada de Ferro Vitória Minas divulgadas pela ANTT ${ }^{38}$ (Gráfico 12).

\footnotetext{
${ }^{38} \mathrm{http}: / /$ www.antt.gov.br/concessaofer/concessionariasfer.asp
} 


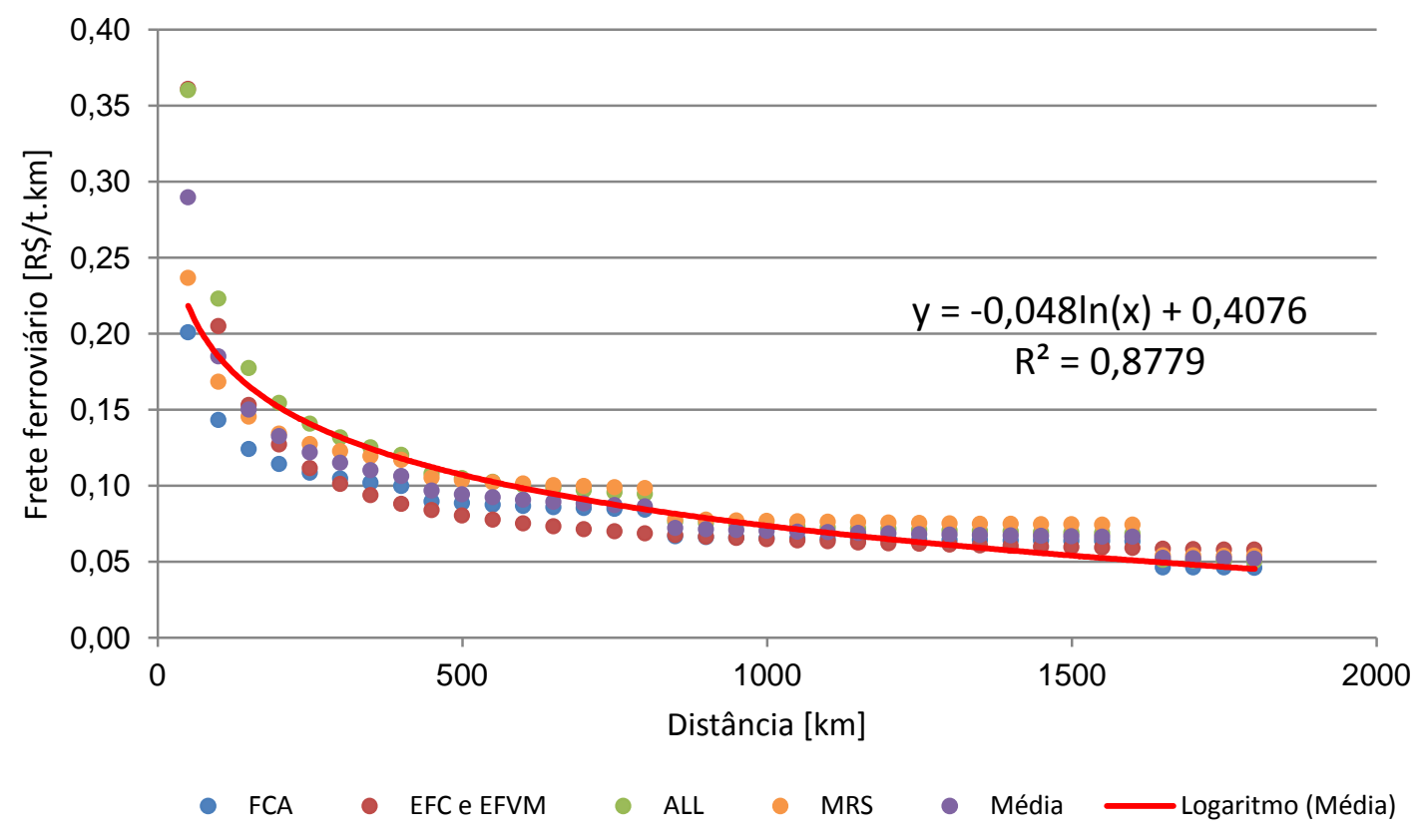

Gráfico 12: Curva de frete ferroviário (R\$/t.km). Fonte: elaboração autor

Do Gráfico 12 determina-se a curva do frete ferroviário $(F f)$ em função da distância:

$$
F_{f}=d *(-0,048 \ln (d)+0,4076)
$$

Onde, $F_{f}$ é dado em $\mathrm{R} \$ / \mathrm{t}$.

\section{Modal hidroviário}

Para fretes hidroviários assumiu-se a média de valores cotados à mercado e obtidos junto ao Sifreca, que resultou em $R \$ 0,041 /$ t.km.

$$
F_{h}=d *(0,041)
$$

Onde, $F_{h}$ é dado em $\mathrm{R} \$ / \mathrm{t}$.

\section{Transbordos e Pedágios}

Transbordos e pedágios são custos diretos que compõe o frete. Para as rotas multimodais com uso de hidrovias considerou-se o valor do transbordo de $R \$ 5 / t$, 
valor esse obtido em entrevistas com Operadores de Transporte Multimodal (OTMs). No caso das ferrovias esse valor já está incluído na tarifação.

Nos estados da região sul e sudeste do Brasil existe grande incidência de pedágios. As rotas que passam por vias tarifadas foram acrescidas dos valores informados pelas concessionárias na rede mundial.

É importante ressaltar que os valores apresentados não foram acrescidos de tributações federais, estaduais ou municipais.

\subsubsection{2 Área de influência dos portos: 0 custo do frete determinando o destino das cargas}

Num cenário de extrema competividade mundial e busca da maximização dos lucros, o destino da produção deve seguir o caminho de menor custo total. Neste contexto e no longo prazo, é razoável assumir que uma região exporte sua carga pelo porto para o qual o frete total é mínimo. Assim, define-se a região de influência do porto como a área na qual o frete é mínimo em relação aos portos concorrentes, determinando, consequentemente, o volume de carga potencial a ser escoado.

Dada a importância da distância no cálculo do frete, a área de influência dos portos determinada por isocustos de transporte - deveria se aproximar da região delimitada por equidistâncias geográficas, considerando mesmas condições de qualidade de vias e o mesmo modal de transporte.

A semelhança esperada entre os mapas de isocusto e equidistância para um único modal também deve existir quando as rotas utilizam mais de um modal, por causa da relevância da distância em qualquer modal. Mesmo que a rota sofra pequenos incrementos de comprimento por causa da multimodalidade, esses são atenuados pela diferença de frete unitário de, por exemplo, ferrovias e hidrovias em relação a rodovias.

Adotando os principais portos de destino - Itacoatiara, Santarém, Belém, Santos e Paranaguá - definiu-se a região de influência aproximada segundo suas bissetrizes 
(Figura 22). Da figura, percebe-se que os portos de Santarém, Paranaguá e Santos possuem ou deveriam possuir grande penetração na região.

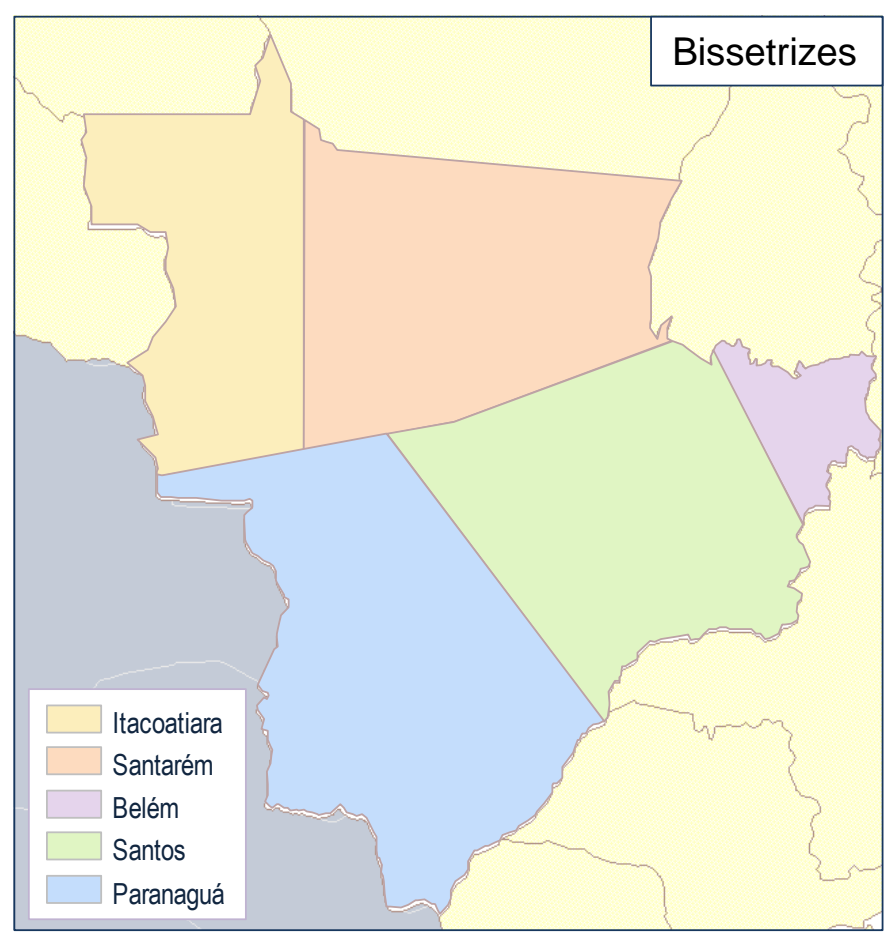

Figura 22: Área de influência determinada por bissetrizes traçadas a cada par de portos. Fonte: elaboração autor

No entanto, a falta de opções de escoamento para as regiões norte e nordeste do país induz a uma predominância de escoamento para as regiões sul e sudeste, atualmente engargaladas. Isso resulta em um distanciamento considerável entre o isocusto atual e o mapa de bissetrizes.

Observa-se que a região de influência do porto de Santos abrange grande parcela do Centro-Oeste, incluindo parte da região central e nordeste do estado do MT, o que justifica o fato do porto exportar $44 \%$ das cargas da região (Figura 23).

Todos os fretes calculados para a definição das áreas de influência de acordo com o exposto no item 4.4.1.1, com origens e destinos estão detalhados no anexo 7.3. 


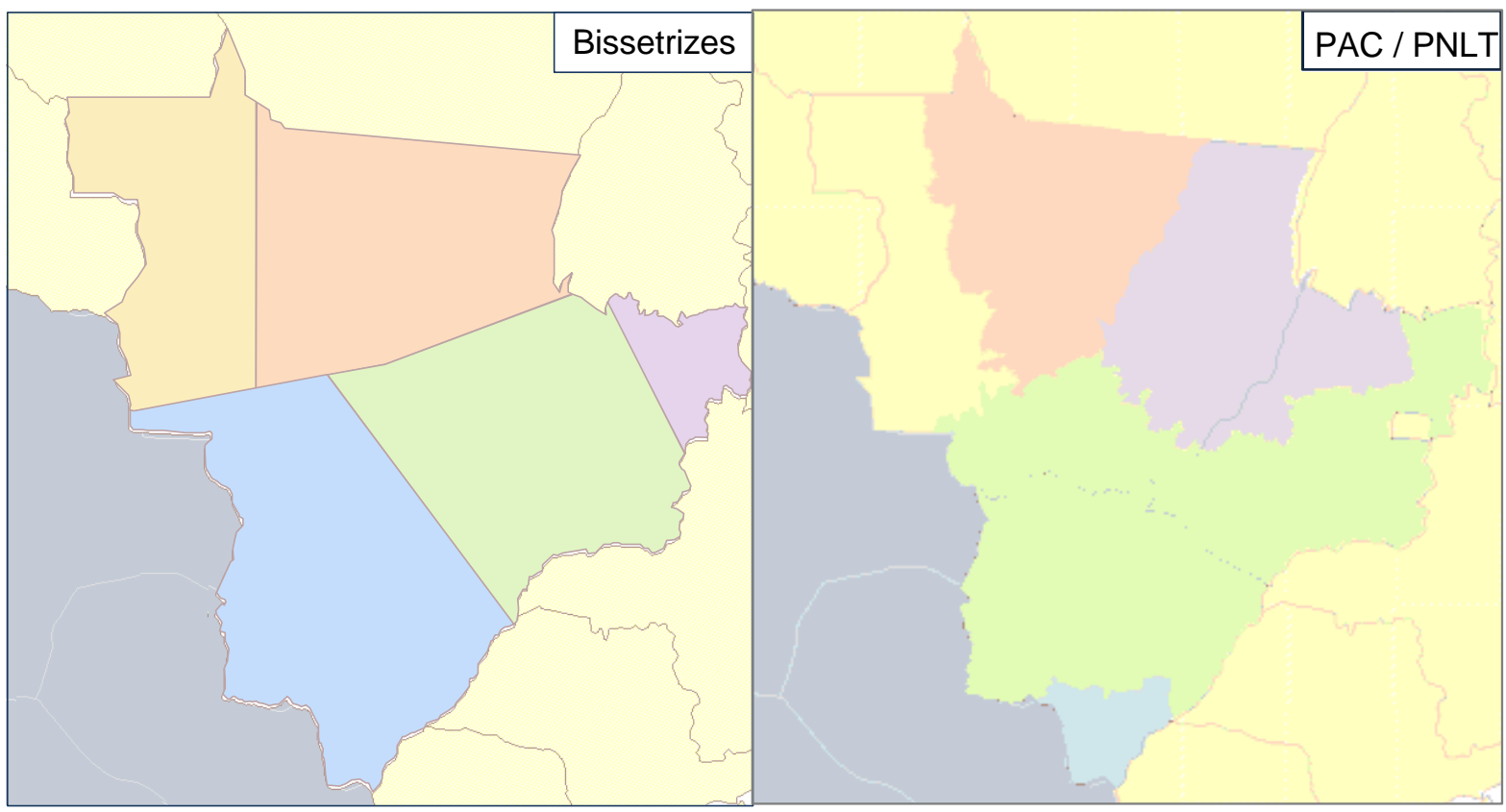

Itacoatiara

Santarém

Belém

$\square$ Santos

Paranaguá

Figura 23: Comparação da área de influência dos portos por bissetrizes e isocusto de transporte no cenário atual de infraestrutura. Fonte: elaboração autor

O mesmo procedimento foi realizado para um cenário em que todas as obras relevantes para o $\mathrm{CO}$ (listadas no item 3.2.3) estivessem concluídas. As obras ilustradas na Figura 24 e detalhadas adiante instituem novos corredores de exportação, possibilitando o deslocamento do vetor de escoamento da região para os portos do norte e nordeste do Brasil ${ }^{39}$.

${ }^{39}$ A Ferrovia de Integração Oeste-Leste (FIOL) que constava no PAC 1 apenas como obra em estudo, não foi considerada como opção para escoamento da produção agrícola do CO. Em 2010, os estudos não haviam sido concluídos. 


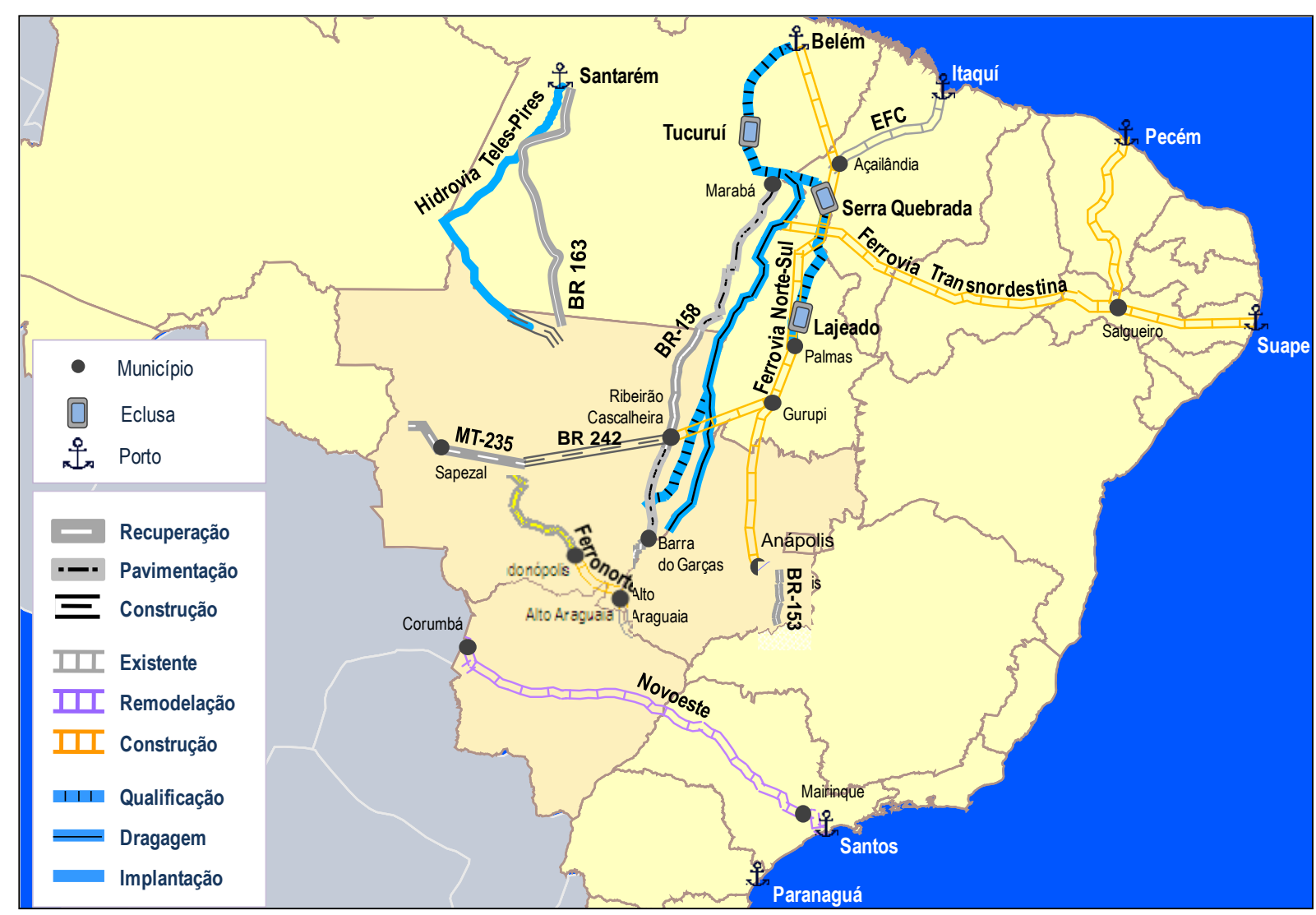

Figura 24: Obras listadas no PNLT e no PAC 1 que afetam a infraestrutura de transportes do CO. Fonte: Adaptado de CEGN (2010)

Detalhando cada corredor de escoamento têm-se as intervenções necessárias constantes ou não no PAC e PNLT.

\section{Corredor 1: Sorriso (MT) - Santos (SP)}

- Ferronorte: Construção de 260 km de Alto Araguaia (MT) a Rondonópolis (MT).

\section{Corredor 2: Sorriso (MT) - Paranaguá (PR)}

- BR-163: Recuperação de aproximadamente 700 km de via (não consta no $\mathrm{PAC} / \mathrm{PNLT})$.

\section{Corredor 3: Sorriso (MT)-Santarém (PA)}

- Hidrovia Teles Pires - Tapajós: Construção rodoviária de $315 \mathrm{~km}$ de Alta Floresta (MT) a Cachoeira Rasteira (MT) e implantação da hidrovia (988 km); 
- BR-163: Pavimentação de 1.024 km de Guarantã do Norte (MT) a Santarém (PA).

\section{Corredor 4: Campo Novo do Parecis (MT)-Itacoatiara (AM)}

- BR-364: Duplicação de Rondonópolis (MT) / Cuiabá a Posto Gil (MT);

- MT-235: Pavimentação de 541 km e construção de 263 km.

\section{Corredor 5: Maracaju (MS)-Santos (SP)}

- Novoeste: Remodelação de $1.185 \mathrm{~km}$ de Corumbá (MS) a Mairinque (SP);

- BR-163: Recuperação de aproximadamente 720 km (não consta no PAC/PNLT).

\section{Corredor 6: Sul de Goiás-Santos}

- Ferrovia Norte Sul: Construção de 1.538 km;

- BR-153: Recuperação de aproximadamente 60 km (não consta no PAC/PNLT).

\section{Corredor 7: Sul de Goiás-Vitória}

- BR-153: Recuperação de aproximadamente $90 \mathrm{~km}$ (não consta no PAC/PNLT).

Os novos corredores criados são:

\section{Corredor 8: Ribeirão Cascalheiro (MT) - Belém (PA)}

- Hidrovia Tocantins- Araguaia (Ria Araguaia e Rio das Mortes): implantação;

- BR-158: Construção e recuperação de aproximadamente $55 \mathrm{~km}$ da rodovia.

\section{Corredor 9: Anápolis (GO)/ Ribeirão Cascalheiro (MT) - Belém (PA)}

- Ferrovia Norte Sul: Construção

Como esperado, a implantação desses investimentos faz o mapa de isocusto futuro se aproximar do mapa de equidistância (Figura 25). O porto de Santos diminui sua área de influência e os portos de Santarém e Belém aumentam consideravelmente. As obras da Hidrovia Teles Pires-Tapajós e da Hidrovia Tocantins-Araguaia são as maiores responsáveis por essa mudança. 
O porto de Itacoatiara também perde área para o porto de Santarém e, apesar dos portos de Itaqui, Pecém e Suape serem viabilizados pelos investimentos, nenhum deles apresenta área de influência para movimentar cargas do Centro-Oeste. Vale notar que a construção da Ferrovia Ferronorte de Alto Araguaia até Rondonópolis ainda deixa o porto de Santos como o maior captador de cargas da região.

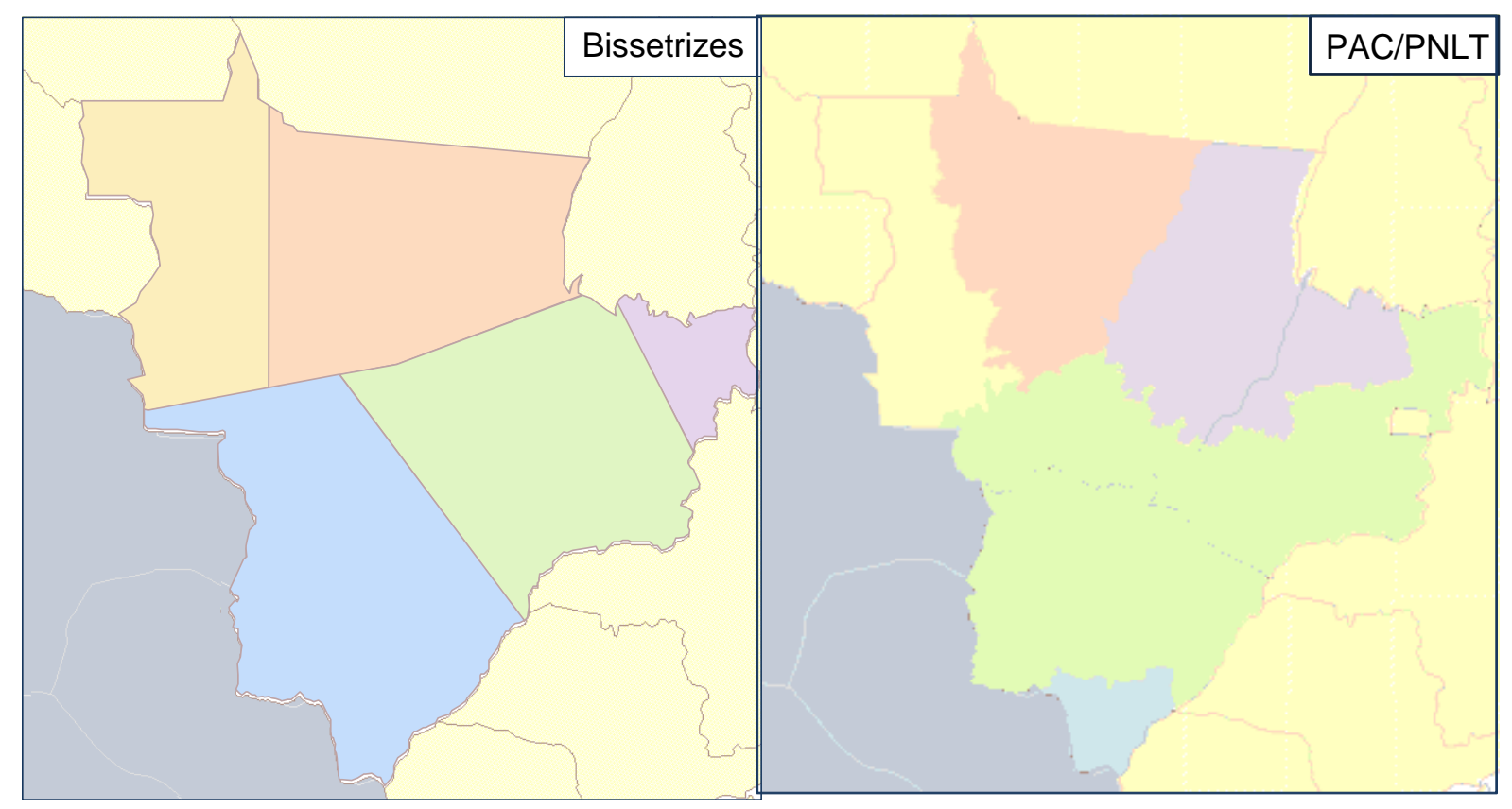

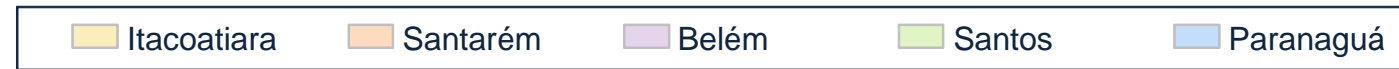

Figura 25: Comparação da área de influência dos portos por equidistância e isocusto de transporte com obras do PAC e PNLT ${ }^{40}$. Fonte: elaboração autor

Com a finalidade de obter um valor "agregado" de frete para cada mesorregião dentro da área de influência, calculou-se o frete das microrregiões para o porto de destino, ponderando posteriormente pela representatividade da produção.

O frete de cada área de influência foi calculado utilizando a seguinte fórmula:

$$
F_{j}=\frac{\sum_{i=1}^{n} P_{i} f_{i}}{\sum_{i=1}^{n} P_{i}}
$$

\footnotetext{
${ }^{40}$ A Tabela 42 (anexo 7.4) apresenta todos os valores utilizados para gerar os gráficos de isocusto.
} 
Onde:

$F_{j}$ : frete da área de influência de um investimento j

$f_{i}$ : frete de cada microrregião i até o porto de destino

$P_{i}:$ produção da microrregião i

Com essa formulação, obteve-se o frete de cada região. A Tabela 32 exemplifica o cálculo para a mesorregião norte do MT.

Tabela 32: Exemplo de cálculo de frete agregado para a mesorregião norte. Fonte: dados: IBGE e CNT (2006) / elaboração autor

\begin{tabular}{|c|c|c|c|c|c|c|c|c|c|c|c|}
\hline \multicolumn{2}{|c|}{ Origem (Mato Grosso) } & \multirow{2}{*}{$\begin{array}{c}\% \text { de } \\
\text { Produção }\end{array}$} & \multirow{2}{*}{$\begin{array}{l}\text { Porto de } \\
\text { destino }\end{array}$} & \multicolumn{2}{|c|}{ Transbordo } & \multicolumn{2}{|c|}{ Rodo } & \multirow{2}{*}{\begin{tabular}{|c|} 
Ferro \\
{$[\mathrm{km}]$}
\end{tabular}} & \multicolumn{2}{|c|}{ Hidro } & \multirow{2}{*}{$\begin{array}{l}\text { Frete } \\
\text { Atual } \\
{[R \$ / t]}\end{array}$} \\
\hline Microrregião & Município & & & Local & {$[R \$ / t]$} & {$[\mathrm{km}]$} & $\begin{array}{c}\text { frete } \\
{[R \$ / t]}\end{array}$ & & {$[\mathrm{km}]$} & $\begin{array}{l}\text { frete } \\
{[R \$ / t]}\end{array}$ & \\
\hline \multirow{2}{*}{$\begin{array}{l}\text { Alto Teles } \\
\text { Pires }\end{array}$} & $\begin{array}{l}\text { Lucas do } \\
\text { Rio Verde }\end{array}$ & $15 \%$ & Itacoatiara & $\begin{array}{l}\text { Porto } \\
\text { Velho }\end{array}$ & 5 & 1485 & 145,39 & 0 & 1056 & 42,24 & \multirow{4}{*}{157,4} \\
\hline & Sorriso & $19 \%$ & Santarém & - & 0 & 1359 & 136,67 & 0 & 0 & 0 & \\
\hline Arinos & $\begin{array}{l}\text { São José do } \\
\text { Rio Claro }\end{array}$ & $30 \%$ & Itacoatiara & $\begin{array}{l}\text { Porto } \\
\text { Velho }\end{array}$ & 5 & 1361 & 136,81 & 0 & 1056 & 42,24 & \\
\hline Sinop & Sinop & $35 \%$ & Santarém & - & 0 & 1276 & 130,73 & 0 & 0 & 0 & \\
\hline
\end{tabular}

Após a determinação do frete para ambos os cenários (atual e futuro), obtêm-se a variação resultante da implantação das obras (Tabela 33). 
Tabela 33: Economia de frete obtida com investimentos do PAC e PNLT. Fonte: elaboração autor

\begin{tabular}{|c|c|c|c|c|c|c|c|c|c|c|}
\hline \multirow{2}{*}{$\begin{array}{c}\text { Grupo de } \\
\text { Investimento }\end{array}$} & \multirow{2}{*}{$\begin{array}{l}\text { Frete } \\
\text { sem } \\
\text { obras } \\
(\mathrm{R} \$ / \mathrm{t})\end{array}$} & \multicolumn{3}{|c|}{$\begin{array}{l}\text { Distâncias médias } \\
\text { sem obras [km] }\end{array}$} & \multirow{2}{*}{$\begin{array}{l}\text { Frete } \\
\text { após } \\
\text { obras } \\
(\mathbf{R} \$ / \mathrm{t})\end{array}$} & \multicolumn{3}{|c|}{$\begin{array}{l}\text { Distâncias com } \\
\text { obras [km] }\end{array}$} & \multicolumn{2}{|c|}{$\begin{array}{l}\text { Redução de } \\
\text { frete }\end{array}$} \\
\hline & & Rodo & Ferro & Hidro & & Rodo & Ferro & Hidro & $\mathbf{R} \$ \mathbf{t}$ & $\%$ \\
\hline $\begin{array}{l}\text { Hidrovia } \\
\text { Tocantins- } \\
\text { Araguaia (Rio } \\
\text { Araguaia e Rio } \\
\text { das Mortes) }\end{array}$ & 173,90 & 1.876 & - & - & 88,49 & 110 & - & 1.570 & 85,41 & $49 \%$ \\
\hline $\begin{array}{l}\text { Hidrovia Teles } \\
\text { Pires-Tapajós }\end{array}$ & 157,36 & 1.370 & - & 1.056 & 103,32 & 430 & - & 1.043 & 54,04 & $34 \%$ \\
\hline Rodovia BR-158 & 173,90 & 1876 & - & - & 136,92 & 941 & - & 406 & 36,98 & $21 \%$ \\
\hline $\begin{array}{l}\text { Ferrovia } \\
\text { Novoeste }\end{array}$ & 108,92 & $\begin{array}{c}1000 \\
10\end{array}$ & 1.083 & $\begin{array}{l}- \\
-\end{array}$ & 88,99 & 40 & 1.300 & - & 19,93 & $18 \%$ \\
\hline $\begin{array}{l}\text { Hidrovia Teles } \\
\text { Pires-Tapajós } \\
\text { mais rodovia BR - } \\
163\end{array}$ & 157,36 & 1.370 & - & 1056 & 132,59 & 430 & - & 1.043 & 24,76 & $16 \%$ \\
\hline $\begin{array}{l}\text { Ferrovia Norte- } \\
\text { Sul }\end{array}$ & 115,64 & 190 & 1.282 & - & 101,56 & 483 & 601 & - & 14,08 & $12 \%$ \\
\hline Rodovia BR-163 & 157,36 & 1.370 & - & 1056 & 138,59 & 1.400 & - & - & 18,77 & $12 \%$ \\
\hline $\begin{array}{l}\text { Ferrovia } \\
\text { Ferronorte }\end{array}$ & 113,05 & & & & 103,45 & 110 & 1.485 & - & 9,60 & $8 \%$ \\
\hline $\begin{array}{l}\text { Hidrovia } \\
\text { Tocantins- } \\
\text { Araguaia (Rio } \\
\text { Tocantins) }\end{array}$ & 115,64 & 190 & 1.282 & - & 119,41 & 354 & - & 1471 & - & - \\
\hline
\end{tabular}

A grande diferença de frete gerada - até $49 \%$ - com as novas opções de escoamento altera o destino das cargas de certas regiões. Um exemplo é a microrregião ${ }^{41}$ de Alta Floreta (MT) que estava na área de influência do porto de Itacoatiara (AM), e com as obras da Hidrovia Teles Pires - Tapajós passa à região de Santarém (PA) (Figura 26).

\footnotetext{
${ }^{41}$ Microrregião é, de acordo com a Constituição brasileira de 1988, um agrupamento de municípios limítrofes. Sua principal utilização é verificada nos estudos estatísticos do IBGE.
} 


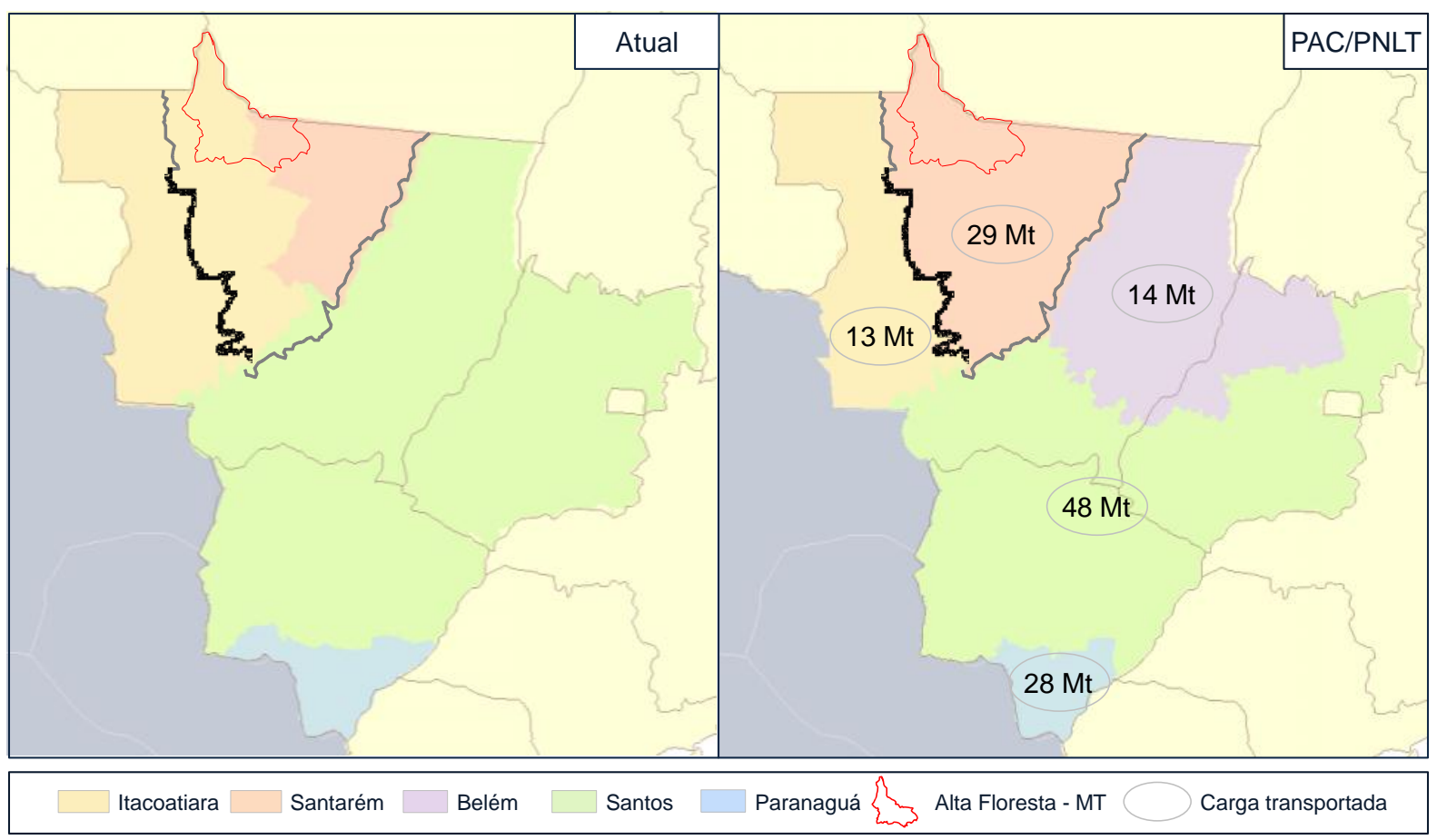

Figura 26: Área de influência da Hidrovia Tapajós-Teles Pires. Fonte: elaboração autor

Portanto, calculada a variação de frete, estimada a carga potencial (CEGN, 2010) e com os investimentos informados pelos programas de governo, obtêm-se o $R$ de cada intervenção. A Tabela 34 apresenta os resultados para os principais investimentos. 
Tabela 34: Carga captada para exportação para cada corredor e redução de frete a cada real investido $(R)$ para os principais investimentos. Fonte: elaboração autor

\begin{tabular}{|c|c|c|c|c|c|c|}
\hline \multirow{2}{*}{ Grupo de Investimento } & \multicolumn{2}{|c|}{ Redução de frete } & \multirow{2}{*}{$\begin{array}{c}\text { Carga } \\
\text { captada } \\
(2023) \\
{[1000 \mathrm{t}]}\end{array}$} & \multirow{2}{*}{$\begin{array}{c}\text { Economia } \\
\text { de frete } \\
{[1000 \mathrm{R} \$]}\end{array}$} & \multirow{2}{*}{$\begin{array}{l}\text { Investimento } \\
\text { [Bi R\$] }\end{array}$} & \multirow[b]{2}{*}{$\mathbf{R}$} \\
\hline & {$[R \$ / t]$} & $\%$ & & & & \\
\hline Hidrovia Teles Pires-Tapajós & 54,04 & $34 \%$ & 29.433 & 1.590 .439 & 1,50 & 1,06 \\
\hline $\begin{array}{l}\text { Hidrovia Tocantins-Araguaia } \\
\text { (Rio Araguaia e Rio das Mortes) }\end{array}$ & 85,41 & $49 \%$ & 14.371 & 1.227 .517 & 1,72 & 0,71 \\
\hline Ferrovia Novoeste & 19,93 & $18 \%$ & 48.124 & 959.067 & 1,60 & 0,60 \\
\hline Ferrovia Ferronorte & 9,60 & $8 \%$ & 48.124 & 462.225 & 0,89 & 0,52 \\
\hline Rodovia BR-163 & 18,77 & $12 \%$ & 29.433 & 552.445 & 1,74 & 0,32 \\
\hline Rodovia BR-158 & 36,98 & $21 \%$ & 14.371 & 531.522 & 1,84 & 0,29 \\
\hline $\begin{array}{l}\text { Hidrovia Teles Pires-Tapajós } \\
\text { mais rodovia BR - } 163\end{array}$ & 24,76 & $16 \%$ & 29.433 & 728.777 & 3,05 & 0,19 \\
\hline Ferrovia Norte-Sul & 14,08 & $12 \%$ & 14.371 & 202.346 & 4,86 & 0,04 \\
\hline $\begin{array}{l}\text { Hidrovia Tocantins-Araguaia } \\
\text { (Rio Tocantins) }\end{array}$ & - & - & 14.371 & - & 2,39 & - \\
\hline
\end{tabular}

$\mathrm{Na}$ Tabela 34 existem três opções de rota para o corredor Sorriso - Santarém. Essas opções foram analisadas separadamente em decorrência da inexistência de avaliações públicas precisas sobre a capacidade ${ }^{42}$ da hidrovia Tele Pires - Tapajós.

Foram gerados, então, três cenários para esse corredor: um com pequeno trecho rodoviário e o restante via hidrovia - com aproximadamente $30 \mathrm{Mt} / \mathrm{ano}$ sendo transportada -; o segundo somente rodoviário e; o terceiro com $5 \mathrm{Mt} /$ ano acessando o porto via hidrovia e o restante via rodovia.

De acordo com o indicar apresentado a hidrovia Teles Pires - Tapajós aparece como investimento de maior $R$ - caso tenha capacidade para transportar os $30 \mathrm{Mt} / a n o$-, seguida da Hidrovia Tocantins-Araguaia, Ferrovia Novoeste e Ferronorte.

A economia de frete calculada para 0 ano de 2023 seria igual a 1,06 vezes 0 montante investido. O investimento reduziria em $34 \%$ o frete, além de capturar altos volumes - $30 \mathrm{Mt}$. Os cálculos do PNLT (apresentados no item 2) reforçam esta

\footnotetext{
${ }^{42}$ Segundo CEGN (2010) as capacidades das novas vias (rodoviárias e ferroviárias) são suficientes para atender a demanda de transporte para o escoamento da produção agrícola do CO.
} 
importância, indicando uma TIRE superior a 24\%a.a., uma das maiores entre todas as obras do plano.

A Hidrovia Tocantins-Araguaia (Rio Araguaia e Rio das Mortes) apresenta a maior redução de fretes $(49 \%)$, no entanto possui aproximadamente metade da carga potencial da Teles-Pires e investimento maior, reduzindo, portanto, o seu retorno.

Nota-se, portanto, que as duas obras prioritárias para a região são investimentos hidroviários. Caso a hidrovia Teles Pires-Tapajós tenha baixa capacidade, a hidrovia Tocantins-Araguaia assume o posto de melhor investimento do CO.

A Tabela 35 e Tabela 36 apresentam os cálculos para todos os investimentos identificados como necessários, detalhando melhor cada intervenção. 
Tabela 35: Carga captada para exportação para cada corredor e redução de frete a cada real investido $(R)$ para todos os investimentos necessários para o CO. Fonte: elaboração autor

\begin{tabular}{|c|c|c|c|c|c|c|c|c|c|c|}
\hline \multicolumn{3}{|c|}{ Origem } & \multirow{2}{*}{$\begin{array}{l}\text { Porto de } \\
\text { destino }\end{array}$} & \multirow{2}{*}{$\begin{array}{c}\text { TOTAL } \\
\text { futuro } \\
\text { [R } \$ / t]\end{array}$} & \multirow{2}{*}{$\begin{array}{c}\text { TOTAL } \\
\text { atual } \\
\text { [R\$/t] }\end{array}$} & \multirow{2}{*}{$\begin{array}{c}\text { Diferença } \\
\text { de frete } \\
\text { [R\$/t] }\end{array}$} & \multirow{2}{*}{$\begin{array}{c}\text { Carga } \\
\text { captada } \\
(2023) \\
{[1000 \mathrm{t}]}\end{array}$} & \multirow{2}{*}{$\begin{array}{l}\text { Investimento } \\
\text { (R\$) }\end{array}$} & \multirow{2}{*}{ Rotas / Vias } & \multirow{2}{*}{$\mathbf{R}$} \\
\hline UF & Microrregião & Município & & & & & & & & \\
\hline \multirow[t]{3}{*}{ MT } & Alto Teles Pires & Sorriso & \multirow[t]{3}{*}{ Santarém } & \multirow[t]{3}{*}{132,59} & \multirow[t]{3}{*}{157,36} & \multirow[t]{3}{*}{24,76} & \multirow[t]{3}{*}{29.433} & \multirow[t]{3}{*}{3.048 .760 .000} & \multirow{3}{*}{$\begin{array}{l}\text { BR- } 163 \text { e Hidr. } \\
\text { Teles Pires-Tapajós }\end{array}$} & \multirow[t]{3}{*}{0,19} \\
\hline & Arinos & São José do Rio Claro & & & & & & & & \\
\hline & Sinop & Sinop & & & & & & & & \\
\hline \multirow[t]{3}{*}{ MT } & Alto Teles Pires & Sorriso & \multirow[t]{3}{*}{ Santarém } & \multirow[t]{3}{*}{103,32} & \multirow[t]{3}{*}{157,36} & \multirow[t]{3}{*}{54,04} & \multirow[t]{3}{*}{29.433} & \multirow[t]{3}{*}{1.498 .760 .000} & \multirow{3}{*}{$\begin{array}{c}\text { Hidr. Teles Pires- } \\
\text { Tapajós }\end{array}$} & \multirow[t]{3}{*}{1,06} \\
\hline & Arinos & São José do Rio Claro & & & & & & & & \\
\hline & Sinop & Sinop & & & & & & & & \\
\hline \multirow[t]{3}{*}{ MT } & Alto Teles Pires & Sorriso & \multirow[t]{3}{*}{ Santarém } & \multirow[t]{3}{*}{138,59} & \multirow[t]{3}{*}{157,36} & \multirow[t]{3}{*}{18,77} & \multirow[t]{3}{*}{29.433} & 1.738 .760 .000 & BR - 163 & 0,32 \\
\hline & Arinos & São José do Rio Claro & & & & & & & & \\
\hline & Sinop & Sinop & & & & & & & & \\
\hline MT & Parecis & $\begin{array}{c}\text { Campo Novo do } \\
\text { Parecis }\end{array}$ & Itacoatiara & 159,37 & 159,37 & 0,00 & 13.481 & 1.300 .000 .000 & BR- 364 e MT - 235 & - \\
\hline & Tangará da Serra & Barra dos Bugres & & & & & & & & \\
\hline & Aripuanã & Brasnorte & & & & & & & & \\
\hline MT & Norte Araguaia & Confresa & Belém & 88,49 & 173,90 & 85,41 & 14.371 & 1.721 .300 .000 & Hidr. Tocantins & 0,71 \\
\hline & Canarana & Querência & & & & & & & Araguaia & \\
\hline MT & Norte Araguaia & Confresa & Belém & 136,92 & 173,90 & 36,98 & 14.371 & 1.841 .300 .000 & BR - 158 (até & 0,29 \\
\hline & Canarana & Querência & & & & & & & $\begin{array}{c}\text { Marabá-PA ) e } \\
\text { hidrovia }\end{array}$ & \\
\hline GO & Porangatu & Niquelândia & Belém & 101,56 & 115,64 & 14,08 & 14.371 & 4.860 .000 .000 & Ferrovia Norte Sul & 0,04 \\
\hline & Ceres & Goianésia & & & & & & & & \\
\hline & $\begin{array}{l}\text { São Miguel do } \\
\text { Araguaia }\end{array}$ & Novo Planalto & & & & & & & & \\
\hline
\end{tabular}


Tabela 36: Carga captada para exportação para cada corredor e redução de frete a cada real investido (R) para todos os investimentos necessários para o CO. Fonte: elaboração autor

\begin{tabular}{|c|c|c|c|c|c|c|c|c|c|c|}
\hline \multicolumn{3}{|c|}{ Origem } & \multirow{2}{*}{$\begin{array}{l}\text { Porto de } \\
\text { destino }\end{array}$} & \multirow{2}{*}{$\begin{array}{c}\text { TOTAL } \\
\text { futuro } \\
\text { [R\$/t] }\end{array}$} & \multirow{2}{*}{$\begin{array}{c}\text { TOTAL } \\
\text { atual } \\
\text { [R\$/t] }\end{array}$} & \multirow{2}{*}{$\begin{array}{c}\text { Diferença } \\
\text { de frete } \\
\text { [R\$/t] }\end{array}$} & \multirow{2}{*}{$\begin{array}{c}\text { Carga } \\
\text { captada } \\
(2023) \\
{[1000 \mathrm{t}]}\end{array}$} & \multirow{2}{*}{ Investimento } & \multirow{2}{*}{ Rotas / Vias } & \multirow{2}{*}{$\mathbf{R}$} \\
\hline UF & Microrregião & Município & & & & & & & & \\
\hline \multirow[t]{3}{*}{ GO } & Porangatu & Niquelândia & \multirow[t]{3}{*}{ Belém } & \multirow[t]{3}{*}{119,41} & \multirow[t]{3}{*}{115,64} & \multirow[t]{3}{*}{$-3,78$} & \multirow[t]{3}{*}{14.371} & \multirow[t]{3}{*}{2.390 .300 .000} & & \multirow[t]{3}{*}{$(0,02)$} \\
\hline & Ceres & Goianésia & & & & & & & & \\
\hline & $\begin{array}{l}\text { São Miguel do } \\
\text { Araguaia }\end{array}$ & Novo Planalto & & & & & & & & \\
\hline \multirow[t]{5}{*}{ MT } & - & $\begin{array}{l}\text { Chapada dos } \\
\text { Guimarães }\end{array}$ & \multirow[t]{5}{*}{ Santos } & \multirow[t]{5}{*}{103,45} & \multirow[t]{5}{*}{113,05} & \multirow[t]{5}{*}{9,60} & \multirow[t]{5}{*}{48.124} & \multirow[t]{5}{*}{890.140 .000} & \multirow[t]{5}{*}{$\begin{array}{l}\text { BR-163 e } \\
\text { Ferronorte }\end{array}$} & \multirow[t]{5}{*}{0,52} \\
\hline & Primavera do Leste & Primavera do Leste & & & & & & & & \\
\hline & Rondonópolis & Itiquira & & & & & & & & \\
\hline & Alto Araguaia & Alto Garças & & & & & & & & \\
\hline & Tesouro & Guiratinga & & & & & & & & \\
\hline \multirow[t]{6}{*}{ GO } & Entornos do DF & Vila Propício & \multirow[t]{6}{*}{ Santos } & \multirow[t]{6}{*}{101,31} & \multirow[t]{6}{*}{101,31} & \multirow[t]{6}{*}{0} & \multirow[t]{6}{*}{48.124} & \multirow[t]{6}{*}{4.600 .000 .000} & Ferrovia Norte Sul - & - \\
\hline & Pires do Rio & Silvânia & & & & & & & Ir & \\
\hline & Catalão & Ipameri & & & & & & & & \\
\hline & Meia Ponte & Goiatuba & & & & & & & & \\
\hline & Sudoeste & Jataí & & & & & & & & \\
\hline & Vale do Rio dos Bois & Turvelândia & & & & & & & & \\
\hline MS & Norte de Dourados & Maracaju & Santos & 88,99 & 108,92 & 19,93 & 48.124 & 1.598 .556 .000 & BR 163 - Ferrovia & 0,60 \\
\hline & Alto Taquari & São Gabriel do Oeste & & & & & & & & \\
\hline & Campo Grande & Sidrolândia & & & & & & & & \\
\hline & Cassilândia & Chapadão do Sul & & & & & & & & \\
\hline MS & Sul de Dourados & Dourados & Paranaguá & 95,88 & 95,88 & 0 & 28.739 & 0 & - & - \\
\hline & GO & Porangatu & & & & & & & & \\
\hline
\end{tabular}




\subsection{Resultados: Obras prioritárias e diferença com a realidade}

A priorização das principais obras considerando exclusivamente o objetivo de maximização do retorno do investimento resulta na seguinte ordem:

1. Hidrovia Teles Pires-Tapajós ${ }^{43}$ (Carga captada 29 Mt; Investimento: $R \$ 1,50$ $\mathrm{Bi} ; \Delta$ frete $[\mathrm{R} \$ / \mathrm{t}]: 54,04)$;

2. Hidrovia Tocantins-Araguaia - Rio Araguaia e Rio das Mortes - (Carga captada:14 Mt; Investimento: $\mathrm{R} \$ 1,72 \mathrm{Bi} ; \Delta$ frete $[\mathrm{R} \$ / \mathrm{t}]$ : 85,41);

3. Ferrovia Novoeste (Carga captada: $48 \mathrm{Mt}$; Investimento: $\mathrm{R} \$ 1,60 \mathrm{Bi} ; \Delta$ frete [R\$/t]: 19,93);

4. Ferrovia Ferronorte (Carga captada: $48 \mathrm{Mt}$; Investimento: $\mathrm{R} \$ 0,89 \mathrm{Bi} ; \Delta$ frete $[R \$ / t]: 9,60)$;

5. Rodovia BR-163 (Carga captada: $29 \mathrm{Mt}$; Investimento: $\mathrm{R} \$ 1,74 \mathrm{Bi}$; $\Delta$ frete [R $\$ / t]: 18,77) ; \mathrm{e}$

6. Rodovia BR-158 (Carga captada: $14 \mathrm{Mt}$; Investimento: $\mathrm{R} \$ 1,84 \mathrm{Bi} ; \Delta$ frete $[R \$ / t]: 54,04)$.

A classificação segundo o critério de redução do impacto ambiental causado pela emissão de $\mathrm{CO}_{2}$ das principais obras estudadas - atendendo ao segundo objetivo da priorização do item 4.4 é completamente diferente da apresentada anteriormente.

A quantidade de poluentes emitidos depende diretamente do modal de transporte escolhido. A emissão de gases do efeito estufa $\left(\mathrm{CO}_{2}\right)$ de uma hidrovia é 5,8 e 1,7 vezes menor por TKU do que do modal rodoviário e ferroviário, respectivamente $(\text { Gráfico 13) })^{44}$.

\footnotetext{
${ }^{43}$ Nesta dissertação, assumiu-se que a hidrovia terá capacidade para transportar toda a produção da região de influência.

${ }^{44}$ A comparação de consumo de combustível também é muito favorável ao transporte hidroviário, com consumo de $5 \mathrm{~L} / \mathrm{tku}$ contra $10 \mathrm{~L} / \mathrm{tku}$ de ferrovias e $96 \mathrm{~L} / \mathrm{tku}$ de rodovias. Fonte: Ministério dos Transportes/ Antaq e U.S. Department of Transportation.
} 


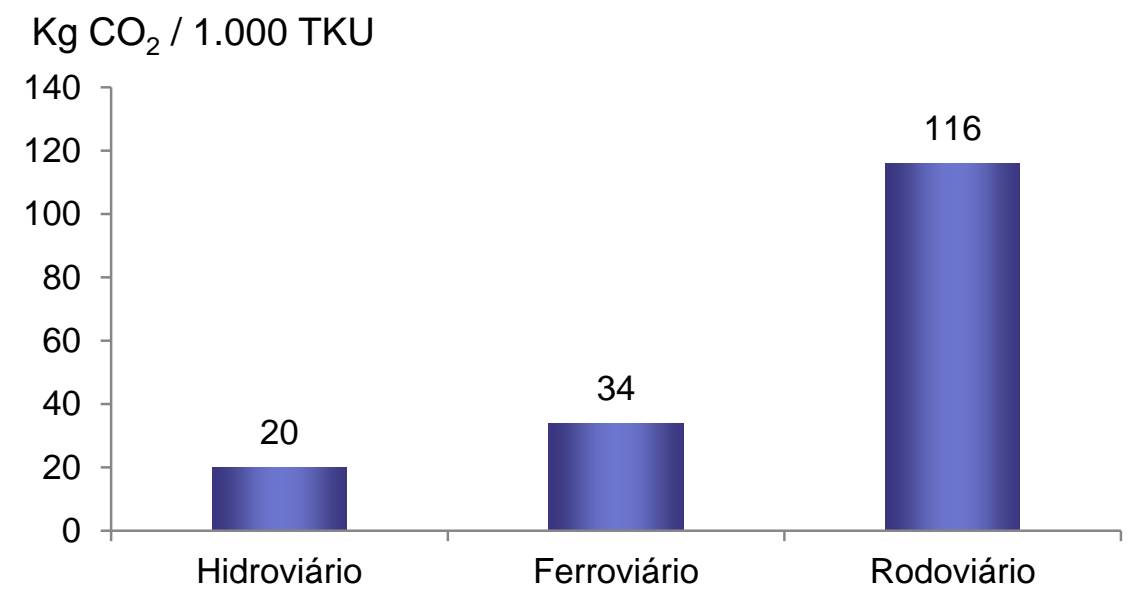

Gráfico 13: Emissão de $\mathrm{CO}_{2}$ por modal [kg/ 1.000TKU]. Fonte: Ministério dos Transportes/ Antaq e U.S. Department of Transportation

Relacionando a emissão de gases do efeito estufa (Gráfico 13), às distâncias de cada uma das rotas e suas cargas potenciais, determinou-se a emissão de $\mathrm{CO}_{2}$ dos investimentos em 2023 - mesmo ano das outras análises.

Atendendo ao objetivo de menor emissão de gases do efeito estufa, a Ferrovia Norte-Sul deveria ser a obra priorizada, seguida pelas Hidrovias Tocantins-Araguaia, Ferrovia Novoeste, BR-158, Ferronorte, Hidrovia Teles Pires-Tapajós e BR-163 (Tabela 37). 
Tabela 37: Priorização de obras atendendo o objetivo de menor emissão de $\mathrm{CO}_{2}$. Fonte:

\begin{tabular}{|c|l|c|c|}
\hline \multicolumn{3}{|c|}{ elaboração autor } \\
\hline Prioridade & \multicolumn{1}{|c|}{ Grupo de Investimento } & $\begin{array}{c}\text { Carga captada } \\
(\mathbf{2 0 2 3 )}[\mathbf{1 0 0 0} \text { t] }\end{array}$ & $\begin{array}{c}\text { Total de emissão } \\
\text { de } \mathbf{C O}_{2} \\
\text { [toneladas] }\end{array}$ \\
\hline 1 & Ferrovia Norte-Sul & 14.371 & 611.132 \\
\hline 2 & $\begin{array}{l}\text { Hidrovia Tocantins-Araguaia (Rio } \\
\text { Araguaia e Rio das Mortes) }\end{array}$ & 14.371 & 971.399 \\
\hline 3 & $\begin{array}{l}\text { Hidrovia Tocantins-Araguaia (Rio } \\
\text { Tocantins) }\end{array}$ & 14.371 & 971.399 \\
\hline 4 & Novoeste & 48.124 & 1.485 .902 \\
\hline 5 & Rodovia BR-158 & 14.371 & 1.993 .260 \\
\hline 7 & Ferronorte & 48.124 & 2.023 .775 \\
\hline 8 & Hidrovia Teles Pires-Tapajós & 29.433 & 2.480 .978 \\
\hline 9 & $\begin{array}{l}\text { Hidrovia Teles Pires-Tapajós mais } \\
\text { rodovia BR -163 }\end{array}$ & 29.433 & 4.358 .577 \\
\hline & Rodovia BR-163 & 29.433 & 4.742 .814 \\
\hline
\end{tabular}

A Ferrovia Norte-Sul que apresenta o menor $R$ (4.4.1) dentre as obras listadas, quando analisada exclusivamente à luz dos impactos ambientais, torna-se a obra prioritária.

Nota-se, portanto, que a cada objetivo traçado, outras intervenções podem figurar nas primeiras posições, mostrando a importância da priorização desses antes da análise detalhada das opções de investimento. Uma figura de mérito ou outras ferramentas mais sofisticadas, como o AHP, devem ser usadas para avaliar cada uma das obras sob todos os objetivos, resultando na priorização direta dos investimentos, no entanto, esse passo não foi contemplado nessa dissertação, ficando como recomendação para trabalhos futuros.

Retomando as obras do PAC e comparando com o resultado obtido na metodologia apresentada neste trabalho, não há nenhuma indicação dos critérios utilizados na escolha das obras. É evidente que esse programa, como explicitado, pode ser tratado como um programa emergencial, mas, mesmo assim, deveria seguir as diretrizes de um planejamento estratégico.

A Hidrovia Teles Pires-Tapajós, por exemplo, que apresenta o maior $R, R=1,06$, e possui grande potencial de captação de carga não figura entre as obras do programa - PAC 1 e 2. Já a BR-163, quinta e nona prioridade em retorno $(R)$ e preservação 
ambiental, respectivamente, está presente. Não se pode afirmar que a BR-163 não seja necessária, muito pelo contrário, mas de acordo com a metodologia apresentada deveria ser uma intervenção secundária. 


\section{Conclusões}

O longo período sem investimento em infraestrutura de transportes no Brasil afetou sobremaneira o desenvolvimento da região Centro-Oeste. Essa, a despeito do tardio desenvolvimento econômico e infraestrutura logística precária, é a região de maior potencial agrícola no país.

A retomada dos investimentos, entretanto, não é condição suficiente para a resolução deste "apagão logístico" criado. Anteriormente ao dispêndio de grandes quantias de dinheiro é necessário um detalhado planejamento estratégico de transportes.

Este trabalho avaliou o único documento gerado no Brasil, nos últimos anos, com a pretensão de ser um planejamento estratégico de transportes - o PNLT - e concluiu que ele não cumpre etapas fundamentais para um processo com este propósito. Desta maneira, sua qualificação como um planejamento estratégico de transportes é questionável.

Dentre os problemas identificados destacam-se o fato de não apresentar claramente seus objetivos, e de não priorizar as alternativas de empreendimentos elencadas. $\mathrm{O}$ PAC tampouco pode ser entendido como um programa que satisfaz a contento esta lacuna de priorização. Denominado um "programa emergencial", o PAC deveria priorizar e financiar as obras propostas pelo PNLT, porém apresenta uma priorização sem regras claras e sugere obras de forma desconexa do PNLT, inclusive inviabilizando algumas das obras deste Plano.

À luz destas deficiências e elaborando um exercício de planejamento simplificado, esta dissertação apresentou passos de um planejamento estratégico adotando uma abordagem guiada por visão e por planejamento (May et al, 2005). O exercício recebeu como input obras concebidas pelo PNLT e/ou constantes no PAC, contemplando a especificação de objetivos e a adoção de procedimentos que permitiram selecionar as melhores opções de infraestrutura com uma ferramenta de análise multicritério - o Analytic Hierarchy Process (AHP).

O planejamento estratégico de um sistema de transportes não é uma tarefa simples. Muito além de aspectos técnicos, ele contempla decisões políticas de instâncias superiores do governo. No entanto, apesar da complexidade, diversos países com 
maior ou menor eficácia, atingiram seus objetivos, melhorando consideravelmente seus sistemas.

Neste trabalho aplicou-se partes de uma metodologia de planejamento de transportes que poderia ser replicada, na íntegra, ao Brasil, sanando sua deficiência histórica.

O trabalho definiu como critérios de decisão - macro-objetivos - o desenvolvimento econômico, desenvolvimento social e preservação ambiental. Definiu ainda, como objetivos específicos, a redução dos custos totais de transporte, a maximização do retorno sobre o investimento, a redução da emissão de gases do efeito estufa, a diminuição do tempo de licenciamento, a maior integração regional e a indução ao desenvolvimento de novas regiões (Figura 27).

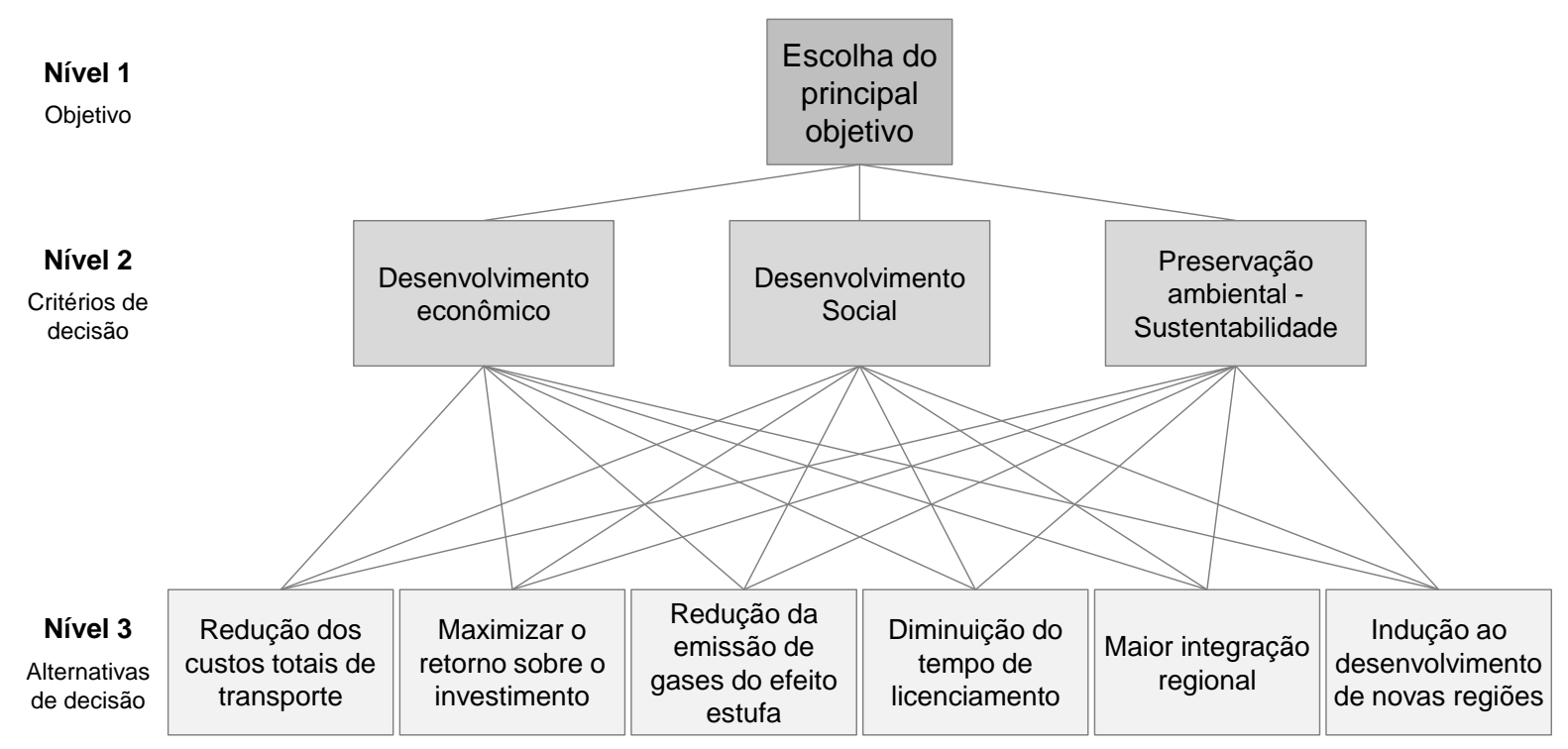

Figura 27: Hierarquia para priorização dos objetivos. Fonte: elaboração autor

A ferramenta foi aplicada ao próprio autor desta dissertação, e deste exercício depreendeu-se que a maximização do retorno sobre o investimento é o principal objetivo a ser atingido. Com este norte, o autor propôs um indicador e priorizou as obras de infraestrutura de transportes listadas no PNLT e no PAC que afetam diretamente a região Centro-Oeste. As obras deveriam ser ranqueadas na seguinte sequência: 
1. Hidrovia Teles Pires-Tapajós;

2. Hidrovia Tocantins-Araguaia (Rio Araguaia e Rio das Mortes);

3. Ferrovia Novoeste;

4. Ferrovia Ferronorte;

5. Rodovia BR-163; e

6. Rodovia BR-158

Para efeito de sensibilidade do exercício, o autor posteriormente admite, por hipótese, a máxima priorização da redução da emissão de gases do efeito estufa. Esta avaliação gera uma priorização completamente diferente da anterior, indicando que análises multicritério deveriam ser aplicadas também à seleção das obras, obtendo um resultado mais alinhado com o rol de macro-objetivos do sistema.

Espera-se que esta dissertação possa ser usada para alimentar futuros trabalhos sobre o assunto, servindo como referência para produzir "massa crítica" focada no planejamento estratégico da infraestrutura de transportes no Brasil.

Outro trabalho que poderia ser elaborado em complementação a este é uma ampliação do exercício ora elaborado, contemplando mais fases (ou todas) do processo geral de planejamento de transportes, além de se aprofundar nas fases realizadas, inclusive aplicando o AHP até o nível da escolha das alternativas. Assim, as opções de investimentos estarão ranqueadas à luz de todos os objetivos específicos, com seus respectivos pesos ponderados, e não apenas do mais importante, como apresentado nesta dissertação. 


\section{Bibliografia}

ABCR. Associação Brasileira de Concessionárias de Rodovias. Relatório Anual 2008, 2008.

AliceWeb. Sistema de Análise das Informações de Comércio Exterior via Internet Secretaria de Comércio Exterior (SECEX), do Ministério do Desenvolvimento, Indústria e Comércio Exterior (MDIC). Acesso em 2008/2009/2010. http://aliceweb.desenvolvimento.gov.br/.

Andrade, A. R., Balssiano, R., Santos, M.P. Planejamento de transportes: informação e participação como fundamentos para o seu desenvolvimento. Revista de Gestão USP, São Paulo, v.13, n. 3, p.13 - 22, julho/setembro 2006.

ASLOG. Associação Brasileira de Logística - Acesso em 2009. http://www.aslog.org.br/novo/.

Association of Americam Railroads. Acesso em 07 de 2008. http://www.aar.org/.

ANEC. Associação Nacional dos Exportadores de Cereais - Acesso em 2008/2009. http://www.anec.com.br/.

ANTF. Associação Nacional de Transportadores Ferroviários - Acesso em 2008/2009/2010. http://www.antfferrovias.org.br/joomla/.

ANUT. Associação Nacional dos Usuários de Transporte de Carga. Soluções para a Competitividade Logística, 2006.

ANUT. Associação Nacional dos Usuários de Transporte de Carga. Transporte Desafio ao Crescimento do Agronegócio Brasileiro, 2008.

Anuário EXAME de infraestrutura 2010. É assim o Brasil Real - dezembro de 2010.

ATC, National Guidelines for Transport System Management in Australia. 2006.

BACEN. Banco Central do Brasil. Acesso em 2008/2009/2010. http://www.bcb.gov.br/.

Banco Mundial. Acesso em 2007/2010. http://www.worldbank.org/.

Banco Mundial. Brazil, How to Decrease Freight Logistics Costs in Brazil, 2008 
BNDES Setorial. A indústria de implementos rodoviários e sua importância para o aumento de eficiência do transporte de cargas no Brasil, 2006.

Bartholomeu, Daniela Bacchi. Quantificação dos impactos econômicos e ambientais decorrentes do estado de conservação das rodovias - Piracicaba, 2006.

Caixeta Filho, José Caixeta. Custos de transporte no agronegócio brasileiro. Seminário CNI - BID - Transporte para o comércio e a integração regional, Brasília, 2008.

Calheiros, Renan. Desafio do crescimento. Gazeta do Oeste, 29 de janeiro de 2007.

Carvalho, Daniele. Como Santos dribla o caos do portão para fora. Gazeta Mercantil, 31 de maio de 2005: C5.

CEGN. Centro de Estudos em Gestão Naval. Análise do potencial agrícola da região Centro Oeste. Relatório técnico, São Paulo. 2010.

CENTRAN. Subsídios Técnicos para a Identificação de Áreas destinadas à instalação de portos públicos ou autorização de terminais de uso privativo de cargas em apoio ao Plano Geral de Outorgas - CENTRAN, 01-09-2009 - Tomo III.

CNT. Confederação Nacional do Transporte. Pesquisa Rodoviária 2006. 2006.

Correa Junior, G.M. Principais determinantes do preço do frete rodoviário para transporte de soja em grãos em diferentes regiões brasileiras: uma análise econométrica. 2001. Dissertação de Mestrado - Escola Superior de Agricultura “Luiz de Queiroz”, Universidade de São Paulo, Piracicaba, 2001.

Colin, Emerson Carlos. Pesquisa Operacional: 170 aplicações em estratégia, finanças, produção, marketing e vendas - Rio de Janeiro. 2007.

De Paula, Germano Mendes, e Ana Paula Avellar. Reforms and infrastructure regulation in Brazil: The experience of ANTT and ANTAQ. The Quarterly Review of Economics and Finance, 2008: 237 - 251.

DEMARCHI, S. H., e SETTI, J. R. A., Análise de Capacidade e Nível de Serviço de Segmentos Básicos de Rodovias utilizando o HCM 2000. 
Emberger, et al. "Ideal" decision-making process for transport planning: A comparison between Europe and South East Asia. Transport Policy. - Cantebury : Elsevier, 2009.

Erhart, Sabrina. Análise do Setor de Transportes, Observatorio de la Economia Latinoamericana, 2006

Estado de São Paulo. TCU: 13 obras do PAC apresentam graves irregularidades, 30 de setembro de 2008.

Folha de São Paulo. Apagão logístico impede o avanço do agronegócio, 08 de fevereiro de 2010.

Fonseca, Fernando. O setor portuário brasileiro. Apresentação, Brasília: ANTAQ, 2008.

Forman, E.; Selly, M. A. Decision by objectives: how to convince others that you are right. World Scientific. ISBN: 9810241437, 2001.

Garber, M. F. Estruturas flutuantes para a exploração de campos de petróleo no mar (FPSO): Apoio à decisão na escolha do sistema, 2002. Dissertação de Mestrado, Escola Politécnica da Universidade de São Paulo, 2002.

GEIPOT, Ministério dos Transportes, Transportes no Brasil: Histórias e Reflexões, 2001.

GEIPOT. Grupo Executivo de Integração da Política de Transportes. Acesso em 2007/2008/2010. http://www.geipot.gov.br/.

Gualda, Nicolau D. F. Terminais de Transportes: Contribuição ao Planejamento e ao Dimensionamento Operacional. Tese de Livre Docência. Departamento de Engenharia de Transportes. Escola Politécnica da Universidade de São Paulo. 1995.

Goldberg, David Joshua Kreppel. Regulação do setor portuário no Brasil. Dissertação de Mestrado, Escola Politécnica da Universidade de São Paulo, 2009. P.225

IBGE. Instituto Brasileiro de Geografia e Estatística. http://www.ibge.gov.br/. IPEA. Instituto de Pesquisa Econômica Aplicada. http://www.ipea.gov.br/portal/. 
Kölbl Robert, Niegl Martin e Knoflacher Hermann. A strategic planning methodology // Transport Policy. - Cantebury : Elsevier, 2008.

Lacerda, S. M., Evolução recente do transporte hidroviário de cargas, BNDES, 2005.

Marchetti, Dalmo dos Santos, e Antonio Pastori. Dimensionamento do potencial de investimentos para o setor portuário. Relatório técnico, Rio de Janeiro: BNDES, 2006.

May et al, Decision Marker's Guidebook, 2005

MDIC - Ministério do Desenvolvimento, Indústria e Comércio Exterior. http://www.mdic.gov.br//sitio/.

Morita, H. Revisão do Método da Análise Hierárquica - MAH (AHP - Analytic Hierarchy Process). 1998. Dissertação (Mestrado) - Escola Politécnica, Universidade de São Paulo. São Paulo, 1998.

Marchetti, Dalmo dos Santos, e Antonio Pastori. Dimensionamento do potencial de investimentos para o setor portuário. Relatório técnico, Rio de Janeiro: BNDES, 2006.

Nogueira, C. W. A Metodologia multicritério de apoio à decisão Analytic Hierarchy Process (AHP): um estudo de caso na priorização de traçado de pavimentação de uma estrada. 2002. Dissertação (Mestrado) - Universidade Federal de Santa Catarina. Florianópolis, 2002.

N.C.B.G. Schneider, Hidrovias Interiores: Um Modal Econômico e Ambientalmente Viável. 2000.

Oliveira, et al. Competition: Competitiveness and development: Lessons from developing countries. Technical report, New York and Geneva: UNCTAD, 2004.

PAC - Programa de Aceleração do Crescimento. http://www.brasil.gov.br/pac.

Padovani, M. Apoio à decisão na seleção do portfólio de projetos / uma abordagem híbrida usando os métodos AHP e programação inteira, 2007. Dissertação (Mestrado) - Escola Politécnica da Universidade de São Paulo. Departamento de Engenharia de Produção, 2007. 
Portugal, Mauricio, Maurício Portugal prevê onda de desestatização nos próximos anos - Encontro Informal IBEF, 2008.

PNLT - Plano Nacional de Logística de Transportes, Ministério dos Transportes. 2007

TCU. Tribunal de Contas da União. Relatório de Avaliação do Programa de Manutenção de Hidrovias, 2006.

Revista Exame, Reportagem Transporte/Hidrovias - Potencial inexplorado, publicado em 09 de novembro de 2004.

Richardson, Tim; Haywood, Russ. Desconstructing transport planning. Lessons from policy breakdown in the English Pennines. - Transport Policy. Cantebury : Elsevier, 1996

Romero, Bianca de Cássia. Análise da Localização de Plataformas Logísticas: aplicação ao caso do ETSP - Entreposto Terminal São Paulo - da CEAGESP, 2006. Dissertação (Mestrado) - Escola Politécnica da Universidade de São Paulo, 2006

SAATY, T. L. The Analytic Hierarchy Process - planning priority setting, resource allocation. New York: Mc Graw Hill, 1980.

SAATY, T. L. Método de Análise Hierárquica. Editora Makron, São Paulo, 1991.

SANTANA, W. A.; TACHIBANA, T. Caracterização dos Elementos de um Projeto Hidroviário, Vantagens, Aspectos e Impactos Ambientais para Proposição de Metodologias Técnico-Ambientais para o Desenvolvimento do Transporte Comercial de Cargas nas Hidrovias Brasileiras. Engevista (UFF), 2004.

SECEX. Informativos Secex. Ministério do Desenvolvimento, Indústria e Comércio Exterior. www.mdic.gov.br/

Sterman, J. D. Business Dynamics: Systems Thinking and Modeling for a Complex World. Mc Graw Hill. Boston.2000.

Shimizu, T. Decisão nas organizações. 2ª edição. 2006.

Tendências. Análise econômica da Resolução 517 da ANTAQ. Análise setorial, São Paulo: Tendências Consultoria, 2006. 
Trujillo, Lourdes, e Gustavo Nombela. Privatization and regulation of the seaport industry. Working paper, Washington: The World Bank, 1999.

USDA - United States Departament of Agriculture. Acesso em 2008/2009. http://www.usdabrazil.org.br/home/.

Transportation Research Board (TRB). Highway Capacity Manual, 2008.

Valente, José Augusto. Empresas e autarquias estratégicas no setor de transportes: GEIPOT" - Agência T1 - 03 de dezembro de 2010.

Wikipedia - Acesso em 2010. http://en.wikipedia.org/wiki/Emergence. 
7 Anexo 


\subsection{Breve descrição dos agentes do setor de transportes}

A elaboração e execução de políticas públicas que estimulem o desenvolvimento do setor de transportes fazem parte das competências do poder público.

A classificação dos órgãos públicos pode ser divida em órgãos de administração direta do poder executivo e autarquias. Os primeiros são responsáveis pela concepção e execução de políticas e também, em alguns casos, de obras públicas, como é o caso do DNIT.

As agências reguladoras fiscalizam e regulam a concessão da construção e exploração de obras ao setor privado e os demais órgãos auxiliadores citados no decorrer desse capítulo, complementam a implementação das políticas deste setor de forma legal.

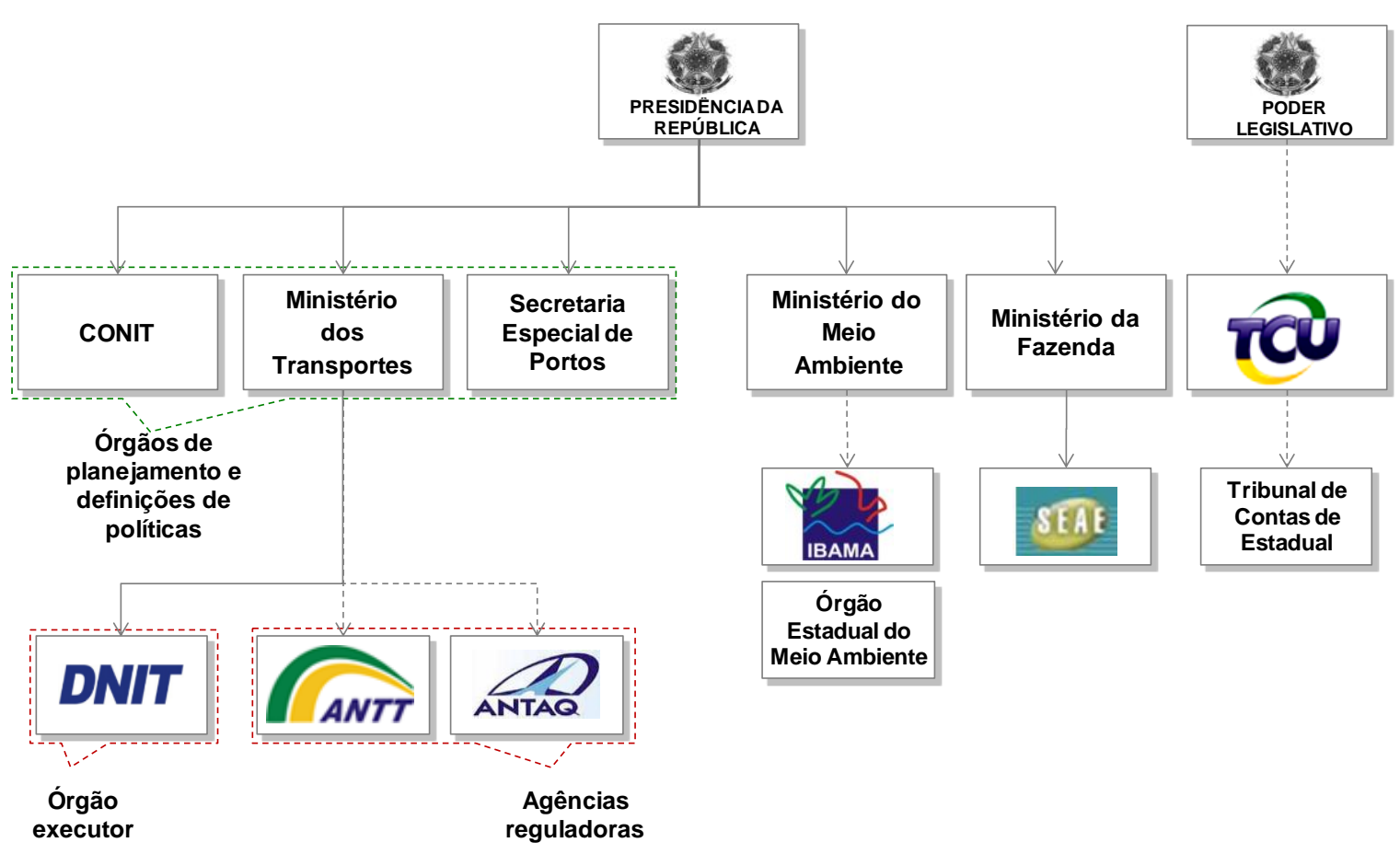

Figura 28: Órgãos atuantes no setor de transporte (Adaptado de Goldberg, 2009)

O papel destes órgãos é garantir o desenvolvimento do setor de transportes, em harmonia com o interesse dos usuários e dos prestadores de serviço. 


\subsubsection{Poder executivo}

O poder executivo federal é composto pelos ministérios do governo, pelo presidente da república juntamente com os órgãos essenciais da presidência e os de assistência direta e imediata. Cabe a estes elaborar e executar políticas públicas que fomentem o desenvolvimento do país.

Destacam-se no setor de transporte os seguintes órgãos:

\section{Conselho Nacional de Integração de Políticas de Transporte (CONIT)}

O CONIT é um órgão vinculado à Presidência da República, criado em 2001, cuja principal atribuição é assessorar o Presidente da República, propondo políticas nacionais de integração dos diferentes modais de transporte.

De acordo com a Lei 10.233 de 2001, deve definir os elementos a serem implementados pelos órgãos reguladores dos transportes terrestres, aéreos e aquaviários, harmonizá-los com as políticas de transporte no âmbito nacional, estadual, do Distrito Federal e dos municípios, aprovar revisões periódicas das redes de transporte nacional e propor reformulações do Plano Nacional de Viação (PNV) ${ }^{45}$ que atendam ao interesse nacional.

A despeito da sua função estratégica, o Decreto 6.555, que dispõe sobre sua estrutura e funcionamento, foi publicado apenas em agosto de 2008, sete anos após sua previsão legal.

A formação do CONIT conta com 10 conselheiros, entre eles ministros e secretários de casas diferentes ${ }^{46}$. Há indícios que o excessivo número de ministérios dificulta as ações do corpo conselheiro. O descompasso das agendas ministeriais foi um

\footnotetext{
${ }^{45}$ Antes do início do processo licitatório, o MnT insere a obra no PNV. O projeto pode ser sugerido por investidor privado, demandado por algum plano de investimento ou pelo próprio MnT.

${ }^{46}$ São conselheiros do CONIT o Ministro dos Transportes, da Casa Civil da Presidência da República; da Defesa; da Justiça; da Fazenda; do Desenvolvimento, Indústria e Comércio Exterior; do Planejamento, Orçamento e Gestão; das Cidades; do Meio Ambiente e o Secretário Especial de Portos.
} 
obstáculo para a definição da primeira reunião do Conselho, que só aconteceu em dezembro de 2009.

Em um artigo publicado em abril de 2009 pela Agência do Senado, o diretor executivo da ANTF, Rodrigo Octaviano Villaça, defendeu a instalação imediata do CONIT, para que houvesse uma visão de médio e longo prazo das diretrizes para o desenvolvimento da matriz de transporte nacional ${ }^{47}$.

A falta de um órgão coordenador, que considere a integração entre todos os modais de transporte, induz à dificuldade de planejamento no longo prazo. Novos investimentos em obras de infraestrutura poderiam ser priorizados com resultados mais eficazes, uma vez que considerado o ganho na implantação dos diferentes modais de transporte.

\section{Ministério dos Transportes $(\mathrm{MnT})^{48}$}

Entre os assuntos da área de competência do MnT, estão as políticas nacionais de transporte ferroviário, rodoviário e aquaviário, bem como os portos e vias navegáveis ${ }^{49}$.

O MnT atua na formulação, coordenação e supervisão das políticas de transporte. É quem define as prioridades dos programas de investimentos e aprova os planos de outorga sob sua responsabilidade.

Dentro de sua estrutura organizacional, como entidades vinculadas e autarquias estão o Departamento Nacional de Infraestrutura de Transportes (DNIT), a Agência Nacional de Transportes Terrestres (ANTT) e a Agência Nacional de Transportes Aquaviários (ANTAQ), criadas pela Lei 10.233 de 2001.

\footnotetext{
${ }^{47}$ http://www.senado.gov.br/agencia/verNoticia.aspx?codNoticia=90487\&titulo=Especialistas $\% 20 \mathrm{em} \%$ 20transporte\%20pedem\%20aprova\%E7\%E3o\%20da\%20MP\%20que\%20simplifica\%20licenciamento $\% 20$ ambiental.

${ }^{48} \mathrm{O}$ Ministério dos Transportes (MnT), com a formação e nomenclatura atual, foi criado em 1992, através da Lei 8.490 de 1992. Existia anteriormente como Ministério dos Transportes e das Comunicações e como Ministério da Infraestrutura entre 1990 e 1992.

${ }^{49} \mathrm{O} \mathrm{MnT}$ também atua na área de transporte aeroviário e na marinha mercante.
} 


\section{Secretaria Especial dos Portos (SEP)}

A Secretaria Especial de Portos da Presidência da República (SEP) é um órgão assessor direto e imediato ao Presidente da República. Sua contribuição baseia-se na formulação de políticas e diretrizes para o fomento do setor portuário, no que tange portos e terminais marítimos.

Sua criação foi uma ação política para "destravar" o setor portuário, desprendendoIhe maior atenção e, desvinculando-o do MnT. Constam em sua esfera de atuação os portos marítimos e portos outorgados e delegados às companhias docas.

A MP 369 de 2007, convertida na Lei 11.518 do mesmo ano, originou a SEP e definiu como uma de suas competências, no Art. 24:

(...) promover a execução e a avaliação de medidas, programas e projetos de apoio ao desenvolvimento da infraestrutura e da superestrutura dos portos e terminais portuários marítimos, bem como dos outorgados às companhias docas.

Dentre as funções da SEP, há a elaboração do Plano Nacional Estratégico dos Portos (PNE/PORTOS).

A SEP é dirigida por um secretário, com status de ministro, nomeado pelo Presidente da República. Tem como estrutura básica o Gabinete, o Instituto Nacional de Pesquisas Hidroviárias (INPH) e outras subsecretarias.

\section{Departamento Nacional de Infraestrutura de Transporte (DNIT)}

O Departamento Nacional de Infraestruturas de Transporte (DNIT) é o órgão executor da política de transportes determinada pelo Governo Federal. É uma autarquia vinculada ao MnT e implantada pelo Decreto 4.219 de 2002.

Seu papel é desempenhar as funções relativas à construção, operação, manutenção e adequação de capacidade dos elementos do PNV sob administração direta da União $0^{50}$. Também estabelece as normas e especificações técnicas para elaboração de projetos, execução de obras viárias e operação adequada das vias e terminais

\footnotetext{
${ }^{50}$ É dirigido por um Conselho Administrativo e por sete diretores nomeados pelo Presidente da República e conta com recursos da União para a execução das obras.
} 
sob sua responsabilidade. Estão em sua esfera de atuação as vias navegáveis, as ferrovias e rodovias federais, as instalações e vias de transbordo e de interface intermodal e as instalações portuárias fluviais e lacustres, excetuadas as outorgadas às companhias docas.

O DNIT é também responsável por estabelecer padrões, normas e especificações técnicas para a elaboração de projetos e execução de obras infraestrutura viária.

\subsubsection{Agências reguladoras}

A progressiva inclusão da iniciativa privada na prestação de serviços públicos exige, em paralelo, a atuação de uma força reguladora que proteja os interesses dos usuários de eventuais abusos dos concessionários, permissionários ou autorizados, fiscalizando-os e atuando como intermediária nas negociações entre estes e o poder público concedente. A elaboração de editais e contratos, a fiscalização e a publicação de normas que regulam a prestação dos serviços são atribuições fundamentais das agências reguladoras.

Idealmente, elas devem surgir paralelamente ao processo de desestatização, dando aos investidores e usuários segurança quanto ao marco regulatório e os papéis de cada instituição. Todavia, não foi o que ocorreu no setor de transportes no Brasil. Como analisam De Paula e Avellar (2008), a ANTAQ e a ANTT fazem parte da terceira de quatro gerações de agências reguladoras no Brasil: 
Tabela 38: Agências reguladoras no Brasil

\begin{tabular}{|l|l|c|c|c|}
\hline \multicolumn{2}{|c|}{ Agência Reguladora } & $\begin{array}{c}\text { Lei de } \\
\text { Criação }\end{array}$ & Ano & Geração \\
\hline ANEEL & Agência Nacional de Energia Elétrica & 9.427 & 1996 & $1^{\text {a }}$ \\
\hline ANATEL & Agência Nacional de Telecomunicações & 9.472 & 1997 & $1^{\text {a }}$ \\
\hline ANP & $\begin{array}{l}\text { Agência Nacional de Petróleo, Gás } \\
\text { Natural e Biocombustíveis }\end{array}$ & 9.478 & 1997 & $1^{\text {a }}$ \\
\hline ANVISA & Agência Nacional de Vigilância Sanitária & 9.782 & 1999 & $2^{\text {a }}$ \\
\hline ANS & Agência Nacional de Saúde Suplementar & 9.961 & 2000 & $2^{\text {a }}$ \\
\hline ANA & Agência Nacional das Águas & 9.984 & 2000 & $2^{\mathrm{a}}$ \\
\hline ANTT & $\begin{array}{l}\text { Agência Nacional de Transportes } \\
\text { Terrestres }\end{array}$ & 10.233 & 2001 & $3^{\mathrm{a}}$ \\
\hline ANTAQ & $\begin{array}{l}\text { Agência Nacional de Transportes } \\
\text { Aquaviários }\end{array}$ & 10.233 & 2001 & $3^{\mathrm{a}}$ \\
\hline ANCINE & Agência Nacional de Cinema & 2.228 & 2001 & $3^{\mathrm{a}}$ \\
\hline ANAC & Agência Nacional de Aviação Civil & 11.182 & 2005 & $4^{\mathrm{a}}$ \\
\hline
\end{tabular}

A criação destas agências ocorreu de forma tardia, tanto para o setor portuário, cujo processo de privatização por meio de arrendamentos havia começado oito anos antes, com a Lei dos Portos, como para o setor rodoviário e ferroviário, cujas concessões da malha federal foram iniciadas em 1995 e 1996, respectivamente.

Houve demora na consolidação do marco regulatório, incluindo a normatização dos processos de concessão. No caso portuário, a iniciativa privada sequer possuía meios legais (principalmente após a publicação da resolução 517 de 2005 da ANTAQ) para investir na movimentação de carga geral de terceiros - basicamente contêineres - uma atribuição de poder público.

A falta de recursos da ANTAQ e da ANTT também prejudicou a qualidade e celeridade dos processos de licitação e a fiscalização dos agentes privados. Levantamento de Oliveira, et al. (2004) mostra que, até 2004, a ANTAQ e a ANTT recebiam menos de $5 \%$ da soma de ANTAQ, ANTT, ANP, ANATEL e ANEEL.

Se esta situação afeta a independência financeira das agências, a influência política afeta sua independência administrativa, e submete os interesses do país aos de

\footnotetext{
${ }^{51}$ De Paula e Avellar (2008) não mencionam a ANAC, criada 4 anos após ANTT e ANTAQ.
} 
grupos políticos ou grandes empresas. Oliveira, et al. (2004) classificam, através de um índice de independência, ANTAQ e ANTT como as agências de pior desempenho - entre ANATEL, ANEEL, ANPP, ANTAQ e ANTT - pois possuem baixa capacidade de imposição de regras aos agentes a quem os serviços foram outorgados e sofrem grande interferência do governo.

\subsubsection{Outros órgãos}

Demais órgãos participam direta ou indiretamente na elaboração de políticas públicas, obras de infraestrutura viária e processo de concessão de exploração do setor de transportes.

Na parte de fiscalização pode-se citar o Tribunal de Contas da União, na parte de acompanhamento e competitividade econômica tem-se a Secretaria de Acompanhamento Econômico (SEAE) e principalmente, na área ambiental, 0 Instituto Brasileiro do Meio Ambiente (IBAMA).

\section{Tribunal de Contas da União ${ }^{52}$ (TCU)}

A CF88 conferiu ao TCU poderes para exercer a fiscalização contábil, financeira, orçamentária, operacional e patrimonial da União e das entidades da administração direta e indireta ${ }^{53}$. Entre outras atividades, cabe ao TCU:

- Julgar as contas dos administradores e demais responsáveis por dinheiros, bens e valores públicos;

- Realizar inspeções e auditorias por iniciativa própria ou por solicitação do Congresso Nacional;

- Fiscalizar as contas nacionais das empresas supranacionais; e

- Fiscalizar a aplicação de recursos da União repassados a estados, ao Distrito Federal e a municípios.

\footnotetext{
${ }^{52}$ Foi institucionalizado pela primeira vez na Constituição Federal de 1890, e instalado três anos mais tarde, com o objetivo de examinar, revisar e julgar as operações relacionadas à receita ou despesa da União. Desde então, a cada reformulação da Constituição, as competências de seus encargos tem sido ampliadas.

${ }^{53}$ Com o auxílio do Congresso Nacional.
} 
Foram conferidas outras atribuições de fiscalização ao TCU através de leis específicas como a Lei de Responsabilidade Fiscal (Lei Complementar 101 de 2000), Lei de Licitações e Contratos (Lei 8.666 de 1993) e Lei de Diretrizes Orçamentárias.

O TCU é formado por nove ministros, dentre os quais o Congresso Nacional é responsável pela escolha de dois terços destes. O outro terço é nomeado pelo Presidente da República, sob aprovação do Senado Federal. A nomeação por diferentes partes do governo podem implicar em possível submissão parcial do TCU a interesses e disputas político-partidários.

As mesmas normas estabelecidas ao TCU pela CF88 se aplicam, no que couber, à organização, composição e fiscalização dos Tribunais de Contas dos Estados e do Distrito Federal, bem como dos Tribunais e Conselhos de Contas dos Municípios. Os Tribunais de Contas Estaduais são regidos pelas respectivas Constituições estaduais e são integrados por sete conselheiros.

Na malha de transportes nacional, o TCU atua na fiscalização e acompanhamento das licitações de concessão de uso da infraestrutura pública e nas obras de construção, quando realizado por órgãos ou agentes públicos. Todas as operações que envolverem desembolso de verba pública federal, deverão sofrer fiscalização por parte do TCU.

\section{Secretaria de Acompanhamento Econômico (SEAE)}

A Secretaria de Acompanhamento Econômico (SEAE) ${ }^{54}$ é um órgão diretamente subordinado ao Ministério da Fazenda.

A SEAE é o órgão do Poder Executivo encarregado de subsidiar decisões no que tange os reajustes e revisões de tarifas públicas, através do acompanhamento dos preços da economia, em busca de um mercado competitivo ${ }^{55}$. Estão entre as competências do SEAE, de acordo com o Decreto 6.764 de 2009:

\footnotetext{
${ }^{54}$ Foi criada pela Medida Provisória 813 de 1995 e teve suas competências recentemente alteradas pelo Decreto 6.764 de 2009.

${ }^{55}$ A SEAE é dirigida por um Secretário e contam com a seguinte estrutura formada por um Gabinete, coordenações gerais, coordenações, gerências e núcleos. A parte de infraestrutura logística cabe à
} 
- Delinear, coordenar e executar as ações do Ministério, no tocante à gestão das políticas de regulação de mercado, de concorrência e de defesa da ordem econômica, de forma a promover a eficiência, o bem-estar do consumo e o desenvolvimento econômico;

- Assegurar a defesa da ordem econômica, em articulação com os demais órgãos do Governo encarregados de garantir a defesa da concorrência;

- Acompanhar a implantação dos modelos de regulação e gestão desenvolvidos pelas agências reguladoras, pelos ministérios setoriais e pelos demais órgãos afins, opinando, a seu juízo ou quando provocada, dentre outros aspectos, acerca:

- (...) dos processos licitatórios que envolvam a privatização de empresas pertencentes à União, com o objetivo de garantir condições máximas de concorrência, analisando as regras de fixação das tarifas de serviços públicos e preços públicos iniciais, bem como as fórmulas paramétricas de reajustes $e$ as condicionantes que afetam os processos de revisão;

- (...) da evolução dos mercados, especialmente no caso de serviços públicos sujeitos aos processos de privatização e de descentralização administrativa, para recomendar a adoção de medidas que estimulem a concorrência e a eficiência econômica na produção dos bens e na prestação dos serviços.

- Promover o desenvolvimento econômico e o funcionamento adequado do mercado, nos setores agrícola, industrial, de comércio e serviços e de infraestrutura.

IBAMA e órgãos ambientais estaduais e municipais

Coordenação-Geral de Transporte e Logística, que tem como competências, de acordo com o Artigo 28, da Portaria 386 de julho de 2009, a implantação dos modelos de regulação e gestão acerca dos ajustes de tarifas e preços públicos e dos processos licitatórios. 
O Instituto Brasileiro do Meio Ambiente e dos Recursos Naturais Renováveis (IBAMA) é uma autarquia federal vinculada ao Ministério do Meio Ambiente. Foi criado pela Lei 7.735 de 1989 e reformulada pela Lei 11.516 de $2007^{56}$.

O IBAMA exerce o poder de polícia ambiental e executa ações da política nacional de meio ambiente. Outra importante atribuição refere-se ao licenciamento ambiental no âmbito federal e à fiscalização, monitoramento e controle ambiental.

Da concepção do projeto à obra final e operante, é necessária a obtenção de três licenças: a Licença Ambiental (LP), a Licença de Instalação (LI) e a Licença de Operação (LO).

Destas, a mais difícil de ser obtida é a LP. Para obtê-la, é preciso a elaboração de documentos que variam de órgão para órgão, porém dois deles sempre necessários para os tipos de obra abordada neste trabalho: o primeiro é o Estudo de Impacto Ambiental (EIA) que tem caráter técnico e deve conter detalhes dos impactos, diferentes alternativas para a execução do projeto e possíveis medidas mitigatórias; o segundo é o Relatório de Impactos sobre o Meio Ambiente (RIMA), que deve ser escrito com uma linguagem direcionada ao grande público que explicite as vantagens e desvantagens do projeto e todas as consequências ambientais de sua implementação.

Ao mesmo tempo em que o empreendedor entrega o EIA/RIMA, ele deve também entrar com o pedido oficial de licenciamento prévio. Cabe ao IBAMA, entre outras responsabilidades:

- Propor e editar normas e padrões de qualidade ambiental;

- O zoneamento e a avaliação de impactos ambientais;

- O licenciamento ambiental, nas atribuições federais;

- A fiscalização ambiental e a aplicação de penalidades administrativas;

- O apoio às emergências ambientais.

As principais diretrizes para execução do licenciamento ambiental estão expressas na Lei 6.938 de 1981 e nas Resoluções do CONAMA.

\footnotetext{
${ }^{56}$ O IBAMA é administrado por um presidente e cinco diretores.
} 
A aprovação do licenciamento ambiental é compartilhada entre o IBAMA, os OEMAs e os OMMAs. Em geral, o licenciamento ambiental é atribuído aos OEMAS. O IBAMA atua no licenciamento de grandes projetos que impactam em mais de um estado, ou em atividades na plataforma continental. Quando o impacto for restrito a um único município, pode ser emitido via órgão ambiental municipal.

Cabe ressaltar que a competência na emissão do licenciamento ambiental é determinada em função da área de abrangência do impacto do empreendimento e não do local de sua instalação. Algumas discussões neste sentido já foram levantadas devido a conflitos de competência entre os órgãos estadual e federal. Entretanto, o Ministério do Meio Ambiente tem tomado medidas para esclarecer possíveis discussões a respeito ${ }^{57}$. Caso a dúvida persista, o IBAMA tem a prerrogativa de decidir quem licencia.

\footnotetext{
${ }^{57}$ Em 2004, MMA emitiu um parecer sobre "Conflito de competências para licenciamento ambiental", devido às dúvidas que surgiram no processo de instalação de um estaleiro no município de Navegantes/SC. Neste documento colhem-se dados que esclarecem o objetivo do licenciamento ambiental e a quem compete, em função da área de abrangência do impacto gerado pelo empreendimento.
} 


\subsection{Detalhamento dos investimentos do PNLT e PAC}

Tabela 39: Detalhamento dos investimentos do PNLT. Fonte: CEGN (2010)

\begin{tabular}{|c|c|c|c|c|c|c|c|}
\hline \multicolumn{2}{|c|}{ Agrupamento } & Via & $\begin{array}{c}\text { Tipo de } \\
\text { intervenção }\end{array}$ & Onde & $\begin{array}{l}\text { Extensão } \\
(\mathrm{Km})\end{array}$ & $\begin{array}{l}\text { Custo } \\
\left(10^{9}\right.\end{array}$ & $\begin{array}{l}\text { Ano indicado } \\
\text { para }\end{array}$ \\
\hline \multirow[t]{2}{*}{1} & \multirow{2}{*}{ 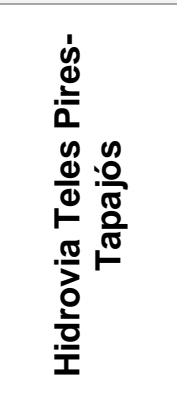 } & $\begin{array}{l}\text { Rodovia } \\
\text { Alta } \\
\text { Floresta- } \\
\text { Cachoeir } \\
\text { a }\end{array}$ & Construção & $\begin{array}{c}\text { Alta } \\
\text { Floresta } \\
\text { (MT) a } \\
\text { Cachoeira } \\
\text { Rasteira } \\
\text { (MT) }\end{array}$ & 315 & 0,21 & \multirow[t]{2}{*}{ 2008-2011 } \\
\hline & & $\begin{array}{c}\text { Hidrovia } \\
\text { Teles } \\
\text { Pires- } \\
\text { Tapajós }\end{array}$ & Implantação & (…, & 988 & 1,1 & \\
\hline \multirow[b]{2}{*}{2} & \multirow{2}{*}{ 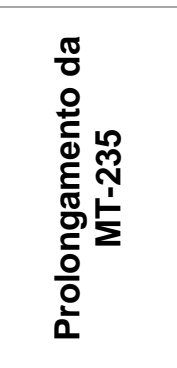 } & \multirow[b]{2}{*}{ MT-235 } & Pavimentação & $\begin{array}{c}\text { Sapezal a } \\
\text { Campo } \\
\text { Novo dos } \\
\text { Parecis }\end{array}$ & 541 & 0,48 & \multirow[b]{2}{*}{$2008-2011$} \\
\hline & & & Construção & $\begin{array}{c}\text { Campo } \\
\text { Novo dos } \\
\text { Parecis a } \\
\text { Ribeirão } \\
\text { Cascalheira }\end{array}$ & 263 & 0,18 & \\
\hline \multirow{4}{*}{3} & \multirow{4}{*}{ 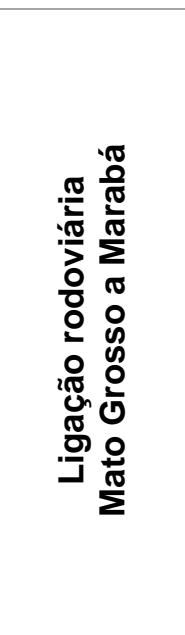 } & MT-100 & Pavimentação & $\begin{array}{c}\text { Alto } \\
\text { Araguaia a } \\
\text { Barra do } \\
\text { Garças }\end{array}$ & 238 & 0,16 & \multirow{4}{*}{$2008-2011$} \\
\hline & & \multirow{3}{*}{ BR-158 } & Recuperação & $\begin{array}{l}\text { Barra do } \\
\text { Garças a } \\
\text { Água Boa }\end{array}$ & 302 & 0,05 & \\
\hline & & & Pavimentação & $\begin{array}{l}\text { Ribeirão } \\
\text { Cascalheira } \\
\text { e divisa } \\
\text { MT/PA }\end{array}$ & 453 & 1,1 & \\
\hline & & & Recuperação & $\begin{array}{l}\text { Divisa } \\
\text { MT/PA a } \\
\text { Marabá }\end{array}$ & 605 & 0,1 & \\
\hline \multirow{4}{*}{4} & \multirow{4}{*}{ 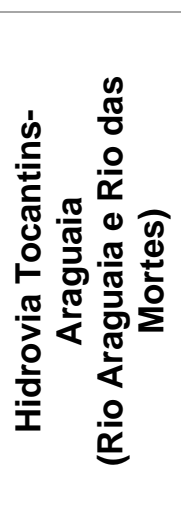 } & \multirow{4}{*}{$\begin{array}{l}\text { Hidrovia } \\
\text { Tocantin } \\
\text { s- } \\
\text { Araguaia }\end{array}$} & Dragagem & $\begin{array}{c}\text { Entre } \\
\text { Tucuruí e } \\
\text { foz do rio } \\
\text { Tocantins }\end{array}$ & 224 & $\begin{array}{c}0,000 \\
3\end{array}$ & \multirow{4}{*}{$2012-2015$} \\
\hline & & & $\begin{array}{l}\text { Dragagem e } \\
\text { balizamento }\end{array}$ & $\begin{array}{l}\text { Entre } \\
\text { Tucuruí e } \\
\text { Marabá }\end{array}$ & 182 & 0,001 & \\
\hline & & & $\begin{array}{l}\text { Construção de } \\
\text { canal }\end{array}$ & $\begin{array}{l}\text { Divisa } \\
\text { TO/PA }\end{array}$ & 396 & 0,59 & \\
\hline & & & $\begin{array}{l}\text { Melhorias para } \\
\text { navegabilidade }\end{array}$ & $\begin{array}{c}\text { Divisa } \\
\text { TO/PA e } \\
\text { TO/MT }\end{array}$ & 1120 & 0,34 & \\
\hline
\end{tabular}




\begin{tabular}{|c|c|c|c|c|c|c|c|}
\hline & & $\begin{array}{l}\text { Hidrovia } \\
\text { do } \\
\text { Marajó }\end{array}$ & Implantação & - & 88 & 0,04 & \\
\hline & & $\begin{array}{l}\text { Eclusa } \\
\text { de } \\
\text { Tucuruí }\end{array}$ & Construção & Tucuruí & 8 & 0,64 & \\
\hline & & $\begin{array}{l}\text { Rio das } \\
\text { Mortes }\end{array}$ & Dragagem & $\begin{array}{l}\text { Entre Nova } \\
\text { Xavantina e } \\
\text { Ribeirão } \\
\text { Cascalheira }\end{array}$ & 389 & 0,11 & \\
\hline \multirow{7}{*}{5} & \multirow{7}{*}{ 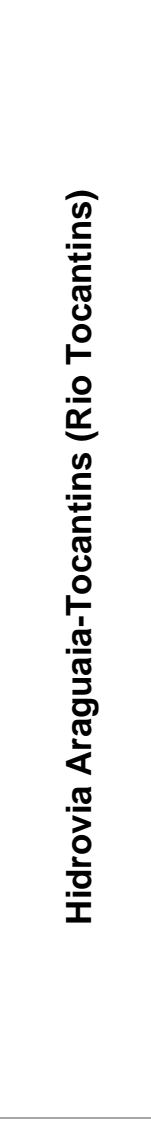 } & \multirow{4}{*}{$\begin{array}{c}\text { Hidrovia } \\
\text { Araguaia } \\
- \\
\text { Tocantin } \\
\text { s }\end{array}$} & $\begin{array}{l}\text { Melhorias para } \\
\text { navegabilidade }\end{array}$ & $\begin{array}{c}\text { Entre } \\
\text { Gurupi (TO) } \\
\text { e Araguaína } \\
\text { (TO) }\end{array}$ & 718 & 0,215 & \multirow{7}{*}{$2012-2015$} \\
\hline & & & $\begin{array}{l}\text { Melhorias para } \\
\text { navegabilidade }\end{array}$ & $\begin{array}{c}\text { Entre } \\
\text { Estreito } \\
\text { (MA) e } \\
\text { Marabá } \\
\text { (PA) }\end{array}$ & 327 & 0,6 & \\
\hline & & & $\begin{array}{l}\text { Dragagem e } \\
\text { balizamento }\end{array}$ & $\begin{array}{l}\text { Entre } \\
\text { Tucuruí e } \\
\text { Marabá }\end{array}$ & 182 & 0,001 & \\
\hline & & & Dragagem & $\begin{array}{l}\text { Entre } \\
\text { Tucuruí e } \\
\text { foz do rio } \\
\text { Tocantins }\end{array}$ & 224 & $\begin{array}{c}0,000 \\
3\end{array}$ & \\
\hline & & $\begin{array}{l}\text { Eclusa } \\
\text { de } \\
\text { Tucuruí }\end{array}$ & Construção & Tucuruí & 8 & 0,64 & \\
\hline & & $\begin{array}{l}\text { Eclusa } \\
\text { de } \\
\text { Lajeado }\end{array}$ & Construção & - & 12 & 0,334 & \\
\hline & & $\begin{array}{c}\text { Eclusa } \\
\text { de Serra } \\
\text { Quebrad } \\
\text { a }\end{array}$ & Construção & - & 0 & 0,6 & \\
\hline \multirow[t]{2}{*}{6} & \multirow[t]{2}{*}{ 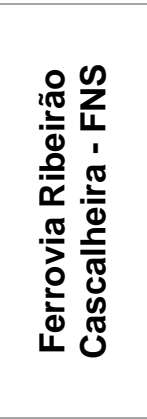 } & $\begin{array}{c}\text { Ramal } \\
\text { ferroviári } \\
\text { o da } \\
\text { ligação } \\
\text { Estreito- } \\
\text { Ribeirão } \\
\begin{array}{c}\text { Cascalhe } \\
\text { ira }\end{array}\end{array}$ & Construção & $\begin{array}{c}\text { Ribeirão } \\
\text { Cascalheira } \\
\text { (MT) a } \\
\text { Gurupi (GO) }\end{array}$ & 415 & 1,1 & \multirow[t]{2}{*}{ 2012-2015 } \\
\hline & & \begin{tabular}{|l} 
Ferrovia \\
Norte-Sul
\end{tabular} & Construção & $\begin{array}{l}\text { Gurupi a } \\
\text { Palmas }\end{array}$ & 190 & 0,5 & \\
\hline 7 & 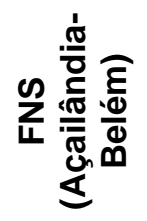 & $\begin{array}{l}\text { Ferrovia } \\
\text { Norte-Sul }\end{array}$ & Construção & $\begin{array}{l}\text { Açailândia a } \\
\text { Porto de } \\
\text { Espadarte }\end{array}$ & 532 & 0,94 & após 2015 \\
\hline
\end{tabular}




\begin{tabular}{|c|c|c|c|c|c|c|c|}
\hline 8 & 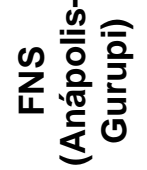 & $\begin{array}{l}\text { Ferrovia } \\
\text { Norte-Sul }\end{array}$ & Construção & $\begin{array}{c}\text { Anápolis } \\
\text { (GO) a } \\
\text { Gurupi (TO) }\end{array}$ & 676 & 2,32 & 2012-2015 \\
\hline 9 & 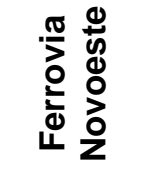 & $\begin{array}{c}\text { Ferrovia } \\
\text { Novoeste }\end{array}$ & Remodelação & $\begin{array}{l}\text { Corumbá } \\
\text { (MS) a } \\
\text { Mairinque } \\
(\mathrm{SP})\end{array}$ & 2489 & 1,185 & após 2015 \\
\hline
\end{tabular}

Tabela 40: Detalhamento dos investimentos do PAC. Fonte: CEGN (2010)

\begin{tabular}{|c|c|c|c|c|c|c|c|}
\hline & Via & $\begin{array}{c}\text { Tipo de } \\
\text { intervenção }\end{array}$ & Onde & $\begin{array}{l}\text { Extensão } \\
(\mathrm{Km})\end{array}$ & $\begin{array}{c}\text { Custo } \\
\left(10^{9}\right. \\
\text { de } \\
\mathbf{R} \$)\end{array}$ & Conclusão & $\begin{array}{l}\text { Situação } \\
\text { da obra }\end{array}$ \\
\hline 10 & BR-163 & Pavimentação & $\begin{array}{c}\text { Guarantã do } \\
\text { Norte (MT) a } \\
\text { Santarém } \\
\text { (PA) }\end{array}$ & 1.024 & 1,55 & $\begin{array}{l}\text { fim de } \\
2011\end{array}$ & $\begin{array}{c}\mathrm{em} \\
\text { andamento }\end{array}$ \\
\hline 11 & BR-242 & $\begin{array}{c}\text { Construção e } \\
\text { pavimentação }\end{array}$ & $\begin{array}{c}\text { Sorriso (MT) } \\
\text { a Ribeirão } \\
\text { Cascalheira } \\
\text { (MT) }\end{array}$ & 314 & 0,2 & 2012 & $\begin{array}{c}\text { ação } \\
\text { preparatória }\end{array}$ \\
\hline 12 & BR-158 & $\begin{array}{l}\text { Construção e } \\
\text { recuperação }\end{array}$ & $\begin{array}{c}\text { Ribeirão } \\
\text { Cascalheira } \\
\text { (MT) até } \\
\text { divisa MT/PA }\end{array}$ & 515 & 0,4 & 2010 & $\begin{array}{c}\text { ação } \\
\text { preparatória }\end{array}$ \\
\hline 13 & BR-364 & Duplicação & $\begin{array}{c}\text { Rondonópolis } \\
\text { (MT)-Cuiabá } \\
\text { (MT)-Posto } \\
\text { Gil (MT) }\end{array}$ & 200 & 0,64 & 2010 & $\begin{array}{c}\text { em } \\
\text { andamento }\end{array}$ \\
\hline 14 & BR-070 & Duplicação & $\begin{array}{c}\text { Brasília (DF) } \\
\text { - Águas } \\
\text { Lindas (GO) }\end{array}$ & 17 & 0,06 & 2009 & $\begin{array}{c}\text { em } \\
\text { andamento }\end{array}$ \\
\hline 15 & BR-153 & Recuperação & $\begin{array}{c}\text { Aparecida de } \\
\text { Goiânia (GO) } \\
\text { - Itumbiara } \\
\text { (GO) }\end{array}$ & 93 & 0,011 & & $\begin{array}{c}\mathrm{em} \\
\text { andamento }\end{array}$ \\
\hline 16 & BR-060 & Duplicação & $\begin{array}{c}\text { Brasília (DF) } \\
\text { - Anápolis } \\
\text { (GO) }\end{array}$ & 93 & 0,022 & - & concluída \\
\hline 17 & BR-158 & $\begin{array}{l}\text { Construção } \\
\text { de ponte }\end{array}$ & $\begin{array}{c}\text { Brasilândia } \\
\text { (MS) - } \\
\text { Paulínia (SP) }\end{array}$ & 1,7 & 0,045 & & $\begin{array}{c}\text { em } \\
\text { andamento }\end{array}$ \\
\hline 18 & Ferronorte & Construção & $\begin{array}{l}\text { Alto Araguaia } \\
\text { (MT) a } \\
\text { Rondonópolis } \\
\text { (MT) }\end{array}$ & 260 & 0,75 & $\begin{array}{l}\text { fim de } \\
2010\end{array}$ & $\begin{array}{c}\text { ação } \\
\text { preparatória }\end{array}$ \\
\hline 19 & $\begin{array}{l}\text { Ferrovia Norte- } \\
\text { Sul (trecho } \\
\text { Norte) }\end{array}$ & Construção & $\begin{array}{c}\text { Açailândia } \\
\text { (MA) a } \\
\text { Palmas (TO) }\end{array}$ & 504 & 1,9 & $\begin{array}{l}\text { fim de } \\
2009\end{array}$ & $\begin{array}{c}\text { em } \\
\text { andamento }\end{array}$ \\
\hline
\end{tabular}




\begin{tabular}{|l|c|c|c|c|c|c|c|}
\hline $\mathbf{2 0}$ & $\begin{array}{c}\text { Ferrovia Norte- } \\
\text { Sul (trecho Sul) }\end{array}$ & Construção & $\begin{array}{c}\text { Santa Fé do } \\
\text { Sul (SP) a } \\
\text { Palmas (TO) }\end{array}$ & 1.538 & 4,6 & $\begin{array}{c}\text { fim de } \\
2011\end{array}$ & $\begin{array}{c}\text { Ao norte de } \\
\text { Anápolis, } \\
\text { em obras. } \\
\text { Ao sul, em } \\
\text { estudos }\end{array}$ \\
\hline $\mathbf{2 1}$ & $\begin{array}{c}\text { Nova } \\
\text { Liga Estreito } \\
\text { (MA) aos } \\
\text { portos de } \\
\text { Pecém (CE) } \\
\text { e Suape (PE) }\end{array}$ & Construçãostina & 1.728 & 4,5 & $\begin{array}{c}\text { Início de } \\
2011\end{array}$ & $\begin{array}{c}\text { em } \\
\text { andamento }\end{array}$ \\
\hline $\begin{array}{c}\text { Ferrovia de } \\
\text { Integração } \\
\text { Oeste-Leste }\end{array}$ & Construção & $\begin{array}{c}\text { Liga Alvorada } \\
\text { (TO) a llhéus } \\
\text { (BA) }\end{array}$ & - & - & - & em estudos \\
\hline $\begin{array}{c}\text { Ferrovia de } \\
\text { Integração } \\
\text { Centro-Oeste }\end{array}$ & Construção & $\begin{array}{l}\text { Uruaçu (GO)- } \\
\text { Sorriso (MT)- } \\
\text { Vilhena (RO) }\end{array}$ & - & - & - & em estudos \\
\hline $\begin{array}{c}\text { Hidrovia } \\
\text { Paraná- } \\
\text { Paraguai }\end{array}$ & $\begin{array}{c}\text { Dragagem, } \\
\text { derrocagem, } \\
\text { sinalização e } \\
\text { balizamento }\end{array}$ & $\begin{array}{l}\text { Rio Paraná e } \\
\text { Rio Paraguai }\end{array}$ & 88 & 0,02 & - & preparatória \\
\hline
\end{tabular}




\subsection{Tabela de fretes atuais}

Tabela 41: Tabela de fretes $[\mathrm{R} \$ / \mathrm{t}]$ atuais para todas as rotas. Fonte: elaboração autor

\begin{tabular}{|c|c|c|c|c|c|c|c|c|c|c|c|c|c|c|}
\hline \multicolumn{3}{|c|}{ Origem } & \multirow{2}{*}{$\begin{array}{l}\text { Porto de } \\
\text { destino }\end{array}$} & \multirow{2}{*}{$\begin{array}{c}\text { Produção } \\
\text { Distância } \\
\text { [km] }\end{array}$} & \multirow{2}{*}{$\begin{array}{l}\text { Transbordo } \\
\text { Frete }[R \$ / t]\end{array}$} & \multicolumn{2}{|c|}{ Rodoviário } & \multicolumn{2}{|c|}{ Ferroviário } & \multicolumn{2}{|c|}{ Hidroviário } & \multirow{2}{*}{$\begin{array}{c}\text { TOTAL } \\
\text { (microrregião) } \\
{[\mathrm{R} \$ / \mathrm{t}]}\end{array}$} & \multirow[t]{2}{*}{ Ponderação } & \multirow{2}{*}{$\begin{array}{l}\text { TOTAL } \\
{[R \$ / t]}\end{array}$} \\
\hline UF & Microrregião & Município & & & & $\begin{array}{c}\text { Distância } \\
{[\mathrm{km}]}\end{array}$ & \begin{tabular}{|c|} 
Distância \\
{$[\mathrm{km}]$}
\end{tabular} & $\begin{array}{l}\text { Frete } \\
{[R \$ / t]}\end{array}$ & \begin{tabular}{|c|}
$\begin{array}{c}\text { Distância } \\
{[\mathrm{km}]}\end{array}$ \\
\end{tabular} & $\begin{array}{l}\text { Frete } \\
{[R \$ / t]}\end{array}$ & \begin{tabular}{|c|} 
Distância \\
{$[\mathbf{k m}]$}
\end{tabular} & & & \\
\hline \multirow{4}{*}{ MT } & Alto Teles & $\begin{array}{l}\text { Lucas do } \\
\text { Rio Verde }\end{array}$ & Itacoatiara & $15 \%$ & Porto Velho & 1485 & 145,4 & 0 & 0 & 1056 & 42,24 & 192,63 & 29,02 & 157,356 \\
\hline & riles & & Santarém & $19 \%$ & - & 1359 & 136,67 & 0 & 0,00 & 0 & 0,00 & 136,67 & 26,20 & \\
\hline & Arinos & $\begin{array}{l}\text { dao Jose } \\
\text { do Rio } \\
\text { Claro }\end{array}$ & Itacoatiara & $30 \%$ & Porto Velho & 1361 & 136,81 & 0 & 0,00 & 1056 & 42,24 & 184,05 & 55,79 & \\
\hline & Sinop & Sinop & Santarém & $35 \%$ & - & 1276 & 130,73 & 0 & 0,00 & 0 & 0,00 & 130,73 & 46,35 & \\
\hline \multirow{3}{*}{ MT } & Parecis & $\begin{array}{l}\text { Campo } \\
\text { Novo do } \\
\text { Parecis }\end{array}$ & \multirow{3}{*}{ Itacoatiara } & $88 \%$ & Porto Velho & 1012 & 110,7 & 0 & 0 & 1056 & 42,24 & 157,96 & 138,64 & 159,365 \\
\hline & $\begin{array}{c}\text { Tangará da } \\
\text { Serra }\end{array}$ & $\begin{array}{l}\text { Barra dos } \\
\text { Bugres }\end{array}$ & & $6 \%$ & Porto Velho & 1243 & 128,33 & 0 & 0,00 & 1056 & 42,24 & 175,57 & 10,60 & \\
\hline & Aripuanã & Brasnorte & & $6 \%$ & Porto Velho & 1082 & 116,21 & 0 & 0,00 & 1056 & 42,24 & 163,45 & 10,12 & \\
\hline \multirow[t]{2}{*}{ MT } & $\begin{array}{c}\text { Norte } \\
\text { Araguaia }\end{array}$ & Confresa & \multirow[t]{2}{*}{ Santos } & $8 \%$ & - & 1810 & 166,5 & 0 & 0 & 0 & 0 & 166,46 & 13,53 & 173,901 \\
\hline & Canarana & Querência & & $92 \%$ & - & 1943 & 174,56 & 0 & 0,00 & 0 & 0,00 & 174,56 & 160,37 & \\
\hline \multirow{3}{*}{ GO } & Porangatu & Niquelândia & \multirow{3}{*}{ Santos } & $66 \%$ & Anápolis & 251 & 37,96 & 1282 & 82,2 & 0 & 0 & 120,14 & 79,49 & 115,635 \\
\hline & Ceres & Goianésia & & $26 \%$ & Anápolis & 135 & 22,93 & 1282 & 82,18 & 0 & 0,00 & 105,11 & 27,59 & \\
\hline & $\begin{array}{l}\text { São Miguel } \\
\text { do Araguaia }\end{array}$ & $\begin{array}{c}\text { Novo } \\
\text { Planalto }\end{array}$ & & $8 \%$ & Anápolis & 192 & 30,58 & 1282 & 82,18 & 0 & 0,00 & 112,76 & 8,56 & \\
\hline \multirow{4}{*}{ MT } & 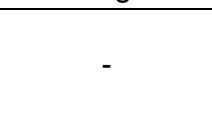 & $\begin{array}{c}\text { Chapada } \\
\text { dos } \\
\text { Guimarães }\end{array}$ & \multirow{4}{*}{ Santos } & $9 \%$ & $\begin{array}{c}\text { Alto } \\
\text { Araguaia }\end{array}$ & 407 & 55,65 & 1333 & 83 & 0 & 0 & 138,61 & 13,15 & 113,052 \\
\hline & $\begin{array}{c}\text { Primavera do } \\
\text { Leste }\end{array}$ & $\begin{array}{l}\text { Primavera } \\
\text { do Leste }\end{array}$ & & $25 \%$ & $\begin{array}{c}\text { Alto } \\
\text { Araguaia }\end{array}$ & 320 & 46,06 & 1333 & 82,95 & 0 & 0,00 & 129,02 & 32,38 & \\
\hline & Rondonópolis & Itiquira & & $34 \%$ & $\begin{array}{c}\text { Alto } \\
\text { Araguaia }\end{array}$ & 111 & 19,50 & 1333 & 82,95 & 0 & 0,00 & 102,46 & 35,34 & \\
\hline & Alto Araguaia & Alto Garças & & $9 \%$ & $\begin{array}{c}\text { Alto } \\
\text { Araguaia }\end{array}$ & 58 & 11,32 & 1333 & 82,95 & 0 & 0,00 & 94,27 & 8,28 & \\
\hline
\end{tabular}




\begin{tabular}{|c|c|c|c|c|c|c|c|c|c|c|c|c|c|c|}
\hline & Tesouro & Guiratinga & & $22 \%$ & $\begin{array}{c}\text { Alto } \\
\text { Araguaia }\end{array}$ & 150 & 25,00 & 1333 & 82,95 & 0 & 0,00 & 107,96 & 23,90 & \\
\hline \multirow{4}{*}{ GO } & Pires do Rio & Silvânia & \multirow{4}{*}{ Santos } & $10 \%$ & Anápolis & 67 & 12,79 & 1282 & 82,2 & 0 & 0 & 94,97 & 9,64 & \multirow{4}{*}{101,305} \\
\hline & Meia Ponte & Goiatuba & & $15 \%$ & - & 791 & 92,39 & 0 & 0 & 0 & 0 & 92,39 & 13,96 & \\
\hline & Sudoeste & Jataí & & $44 \%$ & - & 1012 & 110,7 & 0 & 0 & 0 & 0 & 110,72 & 49,20 & \\
\hline & $\begin{array}{l}\text { Vale do Rio } \\
\text { dos Bois }\end{array}$ & Turvelândia & & $8 \%$ & - & 890 & 100,8 & 0 & 0 & 0 & 0 & 100,80 & 7,76 & \\
\hline \multirow{3}{*}{ MS } & Alto Taquari & $\begin{array}{c}\text { São Gabriel } \\
\text { do Oeste }\end{array}$ & \multirow{3}{*}{ Santos } & $17 \%$ & - & 1130 & 119,89 & 0 & 0,00 & 0 & 0,00 & 119,89 & 20,19 & \multirow{3}{*}{108,919} \\
\hline & $\begin{array}{l}\text { Campo } \\
\text { Grande }\end{array}$ & Sidrolândia & & $21 \%$ & - & 1008 & 110,40 & 0 & 0,00 & 0 & 0,00 & 110,40 & 23,23 & \\
\hline & Cassilândia & $\begin{array}{c}\text { Chapadão } \\
\text { do Sul }\end{array}$ & & $12 \%$ & - & 10 & 2,48 & 1083 & 78,19 & 0 & 0,00 & 80,67 & 9,56 & \\
\hline MS & $\begin{array}{c}\text { Sul de } \\
\text { Dourados }\end{array}$ & Dourados & Paranaguá & $45 \%$ & - & 899 & 101,6 & 0 & 0 & 0 & 0 & 101,55 & 45,62 & 95,8822 \\
\hline
\end{tabular}


7.4 Tabela de fretes futuros

Tabela 42: Tabela de fretes[R $\$ / t]$ futuros para todas as rotas. Fonte: elaboração autor

\begin{tabular}{|c|c|c|c|c|c|c|c|c|c|c|c|c|c|c|}
\hline \multicolumn{2}{|r|}{ Origem } & \multirow[b]{2}{*}{ Município } & \multirow{2}{*}{$\begin{array}{l}\text { Porto de } \\
\text { destino }\end{array}$} & \multirow[t]{2}{*}{ Produção } & \multirow[t]{2}{*}{ Transbordo } & \multicolumn{2}{|c|}{ Rodoviário } & \multicolumn{2}{|c|}{ Ferroviário } & \multicolumn{2}{|c|}{ Hidroviário } & \multirow{2}{*}{$\begin{array}{c}\text { TOTAL } \\
\text { (microrregião) } \\
{[\mathrm{R} \$ / \mathrm{t}]} \\
\end{array}$} & \multirow{2}{*}{$\begin{array}{c}\text { Ponderação } \\
{[R \$ / t]}\end{array}$} & \multirow{2}{*}{$\begin{array}{c}\text { TOTAL } \\
\text { [R } \$ / t]\end{array}$} \\
\hline UF & Microrregião & & & & & $\begin{array}{l}\text { Distância } \\
\text { [km] }\end{array}$ & $\begin{array}{l}\text { Frete } \\
{[R \$ / t]}\end{array}$ & $\begin{array}{l}\text { Distância } \\
\text { [km] }\end{array}$ & $\begin{array}{l}\text { Frete } \\
{[R \$ / t]}\end{array}$ & $\begin{array}{l}\text { Distância } \\
{[\mathrm{km}]}\end{array}$ & $\begin{array}{l}\text { Frete } \\
{[R \$ / t]}\end{array}$ & & & \\
\hline MT & $\begin{array}{l}\text { Alto Teles } \\
\text { Pires } \\
\text { Arinos } \\
\\
\text { Sinop }\end{array}$ & $\begin{array}{l}\text { Sorriso } \\
\text { São José } \\
\text { do Rio } \\
\text { Claro } \\
\text { Sinop }\end{array}$ & Santarém & $\begin{array}{l}34,2 \% \\
30,3 \% \\
35,5 \%\end{array}$ & $\begin{array}{l}\text { Alta Floresta } \\
\text { Alta Floresta } \\
\text { Alta Floresta }\end{array}$ & $\begin{array}{l}384 \\
603\end{array}$ & $\begin{array}{l}53,18 \\
75,34 \\
43,88\end{array}$ & $\begin{array}{c}0 \\
0\end{array}$ & $\begin{array}{l}0,00 \\
0,00\end{array}$ & $\begin{array}{l}1043 \\
1043\end{array}$ & $\begin{array}{r}41,72 \\
41,72 \\
41,72\end{array}$ & $\begin{array}{r}99,90 \\
122,06 \\
90,60\end{array}$ & $\begin{array}{l}34,20 \\
37,00 \\
32,12\end{array}$ & 132,59 \\
\hline MT & $\begin{array}{l}\text { Alto Teles } \\
\text { Pires } \\
\text { Arinos } \\
\text { Sinop }\end{array}$ & $\begin{array}{l}\text { Sorriso } \\
\text { São José } \\
\text { do Rio } \\
\text { Claro } \\
\text { Sinop }\end{array}$ & Santarém & $\begin{array}{l}34,2 \% \\
30,3 \% \\
35,5 \%\end{array}$ & $\begin{array}{l}\text { Alta Floresta } \\
\text { Alta Floresta } \\
\text { Alta Floresta }\end{array}$ & $\begin{array}{l}384 \\
603 \\
301\end{array}$ & $\begin{array}{l}53,18 \\
75,34 \\
43,88\end{array}$ & $\begin{array}{l}0 \\
0\end{array}$ & $\begin{array}{l}0,00 \\
0,00 \\
0,00\end{array}$ & $\begin{array}{l}1043 \\
1043 \\
1043\end{array}$ & $\begin{array}{l}41,72 \\
41,72 \\
41,72\end{array}$ & $\begin{array}{r}99,90 \\
122,06 \\
90,60\end{array}$ & $\begin{array}{l}34,20 \\
37,00 \\
32,12\end{array}$ & 103,32 \\
\hline MT & $\begin{array}{l}\text { Alto Teles } \\
\text { Pires } \\
\text { Arinos } \\
\\
\text { Sinop }\end{array}$ & $\begin{array}{l}\text { Sorriso } \\
\text { São José } \\
\text { do Rio } \\
\text { Claro } \\
\text { Sinop }\end{array}$ & Santarém & $\begin{array}{l}34,2 \% \\
30,3 \% \\
35,5 \%\end{array}$ & $\begin{array}{l}\text { Alta Floresta } \\
\text { Alta Floresta } \\
\text { Alta Floresta }\end{array}$ & $\begin{array}{r}1344 \\
1590 \\
1261\end{array}$ & $\begin{array}{r}135,61 \\
152,41 \\
129,64\end{array}$ & $\begin{array}{l}0 \\
0\end{array}$ & $\begin{array}{l}0,00 \\
0,00 \\
0,00\end{array}$ & $\begin{array}{l}0 \\
0\end{array}$ & $\begin{array}{l}0,00 \\
0,00 \\
0,00\end{array}$ & $\begin{array}{l}135,61 \\
152,41 \\
129,64\end{array}$ & $\begin{array}{l}46,43 \\
46,20 \\
45,96\end{array}$ & 138,59 \\
\hline MT & $\begin{array}{l}\text { Parecis } \\
\text { Tangará da } \\
\text { Serra } \\
\text { Aripuanã }\end{array}$ & $\begin{array}{c}\text { Campo } \\
\text { Novo do } \\
\text { Parecis } \\
\text { Barra dos } \\
\text { Bugres } \\
\text { Brasnorte }\end{array}$ & Itacoatiara & $\begin{array}{l}87,8 \% \\
6,0 \% \\
6,2 \%\end{array}$ & $\begin{array}{l}\text { Porto Velho } \\
\text { Porto Velho } \\
\text { Porto Velho }\end{array}$ & $\begin{array}{l}1243 \\
1082\end{array}$ & $\begin{array}{l}110,72 \\
128,33 \\
116,21\end{array}$ & $\begin{array}{l}0 \\
0\end{array}$ & $\begin{array}{l}0,00 \\
0,00 \\
0,00\end{array}$ & $\begin{array}{r}1056 \\
1056 \\
1056\end{array}$ & $\begin{array}{l}42,24 \\
42,24 \\
42,24\end{array}$ & $\begin{array}{r}157,96 \\
175,57 \\
163,45\end{array}$ & $\begin{array}{r}138,64 \\
10,60 \\
10,12\end{array}$ & 159,37 \\
\hline MT & $\begin{array}{c}\text { Norte } \\
\text { Araguaia } \\
\text { Canarana }\end{array}$ & $\begin{array}{l}\text { Confresa } \\
\text { Querência }\end{array}$ & Belém & $\begin{array}{l}8,1 \% \\
91,9 \%\end{array}$ & $\begin{array}{l}- \\
-\end{array}$ & $\begin{array}{l}120 \\
80\end{array}$ & $\begin{array}{l}20,81 \\
14,84\end{array}$ & $\begin{array}{l}0 \\
0\end{array}$ & $\begin{array}{l}0,00 \\
0,00\end{array}$ & $\begin{array}{l}1410 \\
1730\end{array}$ & $\begin{array}{l}56,40 \\
69,20\end{array}$ & $\begin{array}{l}82,21 \\
89,04\end{array}$ & $\begin{array}{r}6,68 \\
81,80\end{array}$ & 88,49 \\
\hline $\mathrm{MT}$ & $\begin{array}{c}\text { Norte } \\
\text { Araguaia } \\
\text { Canarana }\end{array}$ & $\begin{array}{l}\text { Confresa } \\
\text { Querência }\end{array}$ & Belém & $\begin{array}{l}8,1 \% \\
91,9 \%\end{array}$ & $\begin{array}{l}- \\
-\end{array}$ & $\begin{array}{r}779 \\
1103\end{array}$ & $\begin{array}{c}91,35 \\
117,83\end{array}$ & $\begin{array}{l}0 \\
0\end{array}$ & $\begin{array}{l}0,00 \\
0,00\end{array}$ & $\begin{array}{l}406 \\
406\end{array}$ & $\begin{array}{l}16,24 \\
16,24\end{array}$ & $\begin{array}{l}112,59 \\
139,07\end{array}$ & $\begin{array}{c}9,15 \\
127,76\end{array}$ & 136,92 \\
\hline GO & Porangatu & Niquelândia & Belém & $66,2 \%$ & Uruaçu & 88 & 16,08 & 1615 & 85,63 & 0 & 0,00 & 101,70 & 67,29 & 101,56 \\
\hline
\end{tabular}




\begin{tabular}{|c|c|c|c|c|c|c|c|c|c|c|c|c|c|c|}
\hline & $\begin{array}{c}\text { Ceres } \\
\text { São Miguel } \\
\text { do Araguaia }\end{array}$ & $\begin{array}{c}\text { Goianésia } \\
\text { Novo } \\
\text { Planalto }\end{array}$ & & $\begin{array}{c}26,2 \% \\
7,6 \%\end{array}$ & $\begin{array}{c}\text { Uruaçu } \\
\text { Porangatu }\end{array}$ & $\begin{array}{l}95 \\
51\end{array}$ & $\begin{array}{l}17,14 \\
10,15\end{array}$ & $\begin{array}{l}1615 \\
1700\end{array}$ & $\begin{array}{l}85,63 \\
85,95\end{array}$ & $\begin{array}{l}0 \\
0\end{array}$ & $\begin{array}{l}0,00 \\
0,00\end{array}$ & $\begin{array}{c}102,76 \\
96,10\end{array}$ & $\begin{array}{r}26,97 \\
7,30\end{array}$ & \\
\hline \multirow[t]{3}{*}{$\overline{\mathrm{GO}}$} & Porangatu & Niquelândia & \multirow[t]{3}{*}{ Belém } & $66,2 \%$ & Gurupi & 417 & 56,72 & 0 & 0,00 & 1471 & 58,84 & 120,56 & 79,76 & \multirow[t]{3}{*}{119,41} \\
\hline & Ceres & Goianésia & & $26,2 \%$ & Gurupi & 444 & 59,55 & 0 & 0,00 & 1471 & 58,84 & 123,39 & 32,39 & \\
\hline & $\begin{array}{l}\text { São Miguel } \\
\text { do Araguaia }\end{array}$ & $\begin{array}{c}\text { Novo } \\
\text { Planalto }\end{array}$ & & $7,6 \%$ & Gurupi & 202 & 31,87 & 0 & 0,00 & 1471 & 58,84 & 95,71 & 7,27 & \\
\hline \multirow[t]{5}{*}{ MT } & - & $\begin{array}{c}\text { Chapada } \\
\text { dos } \\
\text { Guimarães }\end{array}$ & \multirow[t]{5}{*}{ Santos } & $9,5 \%$ & Rondonópolis & 207 & 32,50 & 1593 & 85,51 & 0 & 0,00 & 118,01 & 11,20 & \multirow[t]{5}{*}{103,45} \\
\hline & $\begin{array}{c}\text { Primavera do } \\
\text { Leste }\end{array}$ & $\begin{array}{l}\text { Primavera } \\
\text { do Leste }\end{array}$ & & $25,1 \%$ & Rondonópolis & 126 & 21,66 & 1593 & 85,51 & 0 & 0,00 & 107,17 & 26,90 & \\
\hline & Rondonópolis & Itiquira & & $34,5 \%$ & Alto Araguaia & 111 & 19,50 & 1333 & 82,95 & 0 & 0,00 & 102,46 & 35,34 & \\
\hline & Alto Araguaia & Alto Garças & & $8,8 \%$ & Alto Garças & 10 & 2,48 & 1453 & 84,41 & 0 & 0,00 & 86,89 & 7,63 & \\
\hline & Tesouro & Guiratinga & & $22,1 \%$ & Alto Garças & 92 & 16,68 & 1453 & 84,41 & 0 & 0,00 & 101,09 & 22,38 & \\
\hline \multirow[t]{6}{*}{$\overline{\mathrm{GO}}$} & $\begin{array}{c}\text { Entornos do } \\
\text { DF }\end{array}$ & $\begin{array}{c}\text { Vila } \\
\text { Propício }\end{array}$ & \multirow[t]{6}{*}{ Santos } & $11 \%$ & Anápolis & 128 & 21,94 & 1282 & 82,18 & 0 & 0,00 & 104,12 & 11,66 & \multirow[t]{6}{*}{101,31} \\
\hline & Pires do Rio & Silvânia & & $10,1 \%$ & Anápolis & 67 & 12,79 & 1282 & 82,18 & 0 & 0,00 & 94,97 & 9,64 & \\
\hline & Catalão & Ipameri & & $11,4 \%$ & Ipameri & 10 & 2,48 & 1042 & 77,16 & 0 & 0,00 & 79,64 & 9,09 & \\
\hline & Meia Ponte & Goiatuba & & $15,1 \%$ & - & 791 & 92,39 & 0 & 0,00 & 0 & 0,00 & 92,39 & 13,96 & \\
\hline & Sudoeste & Jataí & & $44,4 \%$ & - & 1012 & 110,72 & 0 & 0,00 & 0 & 0,00 & 110,72 & 49,20 & \\
\hline & $\begin{array}{l}\text { Vale do Rio } \\
\text { dos Bois }\end{array}$ & Turvelândia & & $7,7 \%$ & - & 890 & 100,80 & 0 & 0,00 & 0 & 0,00 & 100,80 & 7,76 & \\
\hline \multirow[t]{4}{*}{ MS } & $\begin{array}{c}\text { Norte de } \\
\text { Dourados }\end{array}$ & Maracaju & \multirow[t]{4}{*}{ Santos } & $50,3 \%$ & Maracaju & 10 & 2,48 & 1464 & 84,52 & 0 & 0,00 & 87,00 & 43,74 & \multirow[t]{4}{*}{88,99} \\
\hline & Alto Taquari & $\begin{array}{c}\text { São Gabriel } \\
\text { do Oeste }\end{array}$ & & $16,8 \%$ & $\begin{array}{l}\text { Campo } \\
\text { Grande }\end{array}$ & 132 & 22,51 & 1309 & 82,60 & 0 & 0,00 & 105,11 & 17,70 & \\
\hline & $\begin{array}{l}\text { Campo } \\
\text { Grande }\end{array}$ & Sidrolândia & & $21,0 \%$ & Sidrolândia & 10 & 2,48 & 1340 & 83,05 & 0 & 0,00 & 85,53 & 18,00 & \\
\hline & Cassilândia & $\begin{array}{l}\text { Chapadão } \\
\text { do Sul }\end{array}$ & & $11,8 \%$ & $\begin{array}{c}\text { Chapadão do } \\
\text { Sul }\end{array}$ & 10 & 2,48 & 1083 & 78,19 & 0 & 0,00 & 80,67 & 9,56 & \\
\hline \multirow[t]{2}{*}{ MS } & $\begin{array}{c}\text { Sul de } \\
\text { Dourados }\end{array}$ & Dourados & Paranaguá & $44,9 \%$ & - & 899 & 101,55 & 0 & 0,00 & 0 & 0,00 & 101,55 & 45,62 & \multirow[t]{2}{*}{95,88} \\
\hline & Iguatemi & Naviraí & & $55,1 \%$ & - & 778 & 91,26 & 0 & 0,00 & 0 & 0,00 & 91,26 & 50,27 & \\
\hline
\end{tabular}

